\title{
AVALIAÇÃO DO POTENCIAL DE EXPANSÃO DA SOJA NA AMAZÔNIA LEGAL: UMA APLICAÇÃO DO MODELO DE VON THÜNEN
}

\section{Aluno: fabiano Guimarães Costa}

\author{
Engenehiro Agrônomo
}

Orientador: Prof. Dr. José Vicente Caixeta Filho

Dissertação apresentada à Escola Superior de Agricultura "Luiz de Queiroz", Universidade de São Paulo, para a obtenção do título de Mestre em Ciências, Área de Concentração: Economia Aplicada.

PIRACICABA

Estado de São Paulo - Brasil

Outubro - 2000 


\title{
Dados Internacionais de Catalogação na Publicaçăo (CIP) DIVISÃo DE BIBLIOTECA E DOCUMENTAÇÃO - Campus "Luiz de Queiroz"/USP
}

\author{
Costa, Fabiano Guimarães. \\ Avaliação do potencial de expansão da soja na Amazônia Legal : uma \\ aplicação do modelo de Von Thünen / Fabiano Guimarães Costa. - - \\ Piracicaba, 2000. \\ $159 \mathrm{p}$. \\ Dissertação (mestrado) - - Escola Superior de Agricultura Luiz de \\ Queiroz, 2000. \\ Bibliografia. \\ 1. Amazônia 2. Logística 3. SIG (Sistema de computador) 4. Soja I. Título
}

CDD 338.17334 
Dedico este trabalho aos meus pais Irene e Fernando, aos meus irmãos, Fábio e Renata que sempre estiveram ao meu lado me apoiando em todas as jornadas de minha vida e, principalmente, à minha esposa Marilsa, por ter estado ao meu lado em todos os momentos, mesmo à distância. 


\section{AGRADECIMENTOS}

Gostaria de agradecer...

A Deus, que permitiu que este projeto se realizasse plenamente e de maneira bastante tranqüila, apesar do intenso trabalho.

Ao Prof. José Vicente Caixeta Filho (para mim a melhor definição da palavra professor) pelo seu empenho e dedicação a este projeto e a este aluno.

A todo o pessoal do Imazon, especialmente ao Eugênio Arima, Beto Veríssimo, Paulo Barreto, Rodney, Carlos, André e ao grande parceiro Marky Brito, que confiaram este importante trabalho a mim, dando a chance a um paulistano de conhecer um mundo tão singular como a Amazônia.

Aos amigos do curso de Economia Aplicada da ESALQ/USP, destacando o Bruno, o Zé, o Marcelo, o Glauco, o Robson, o Dautro, o Ari, o Leopoldo e o Paulinho, pelos bons momentos que passaram e pelas amizades que ficaram.

Ao pessoal do Imaflora que sempre apoiou e incentivou o projeto, contribuindo imensamente para a riqueza das discussões deste tema que é, por natureza, bastante complexo.

A todas as pessoas que contribuíram para o sucesso das viagens, em especial o Sr. Vitório Cella, Manoel Amaral, Rubens Gomes, Vicente Godinho (EMBRAPA Vilhena), Luis Antônio Pagot (Hermasa), Alfredo Homma (EMBRAPA CPATU) e à FAMATO.

À CAPES e à Fundação Ford, que deram o suporte financeiro a este projeto. 


\section{$\underline{\text { ÍNDICE }}$}

1 INTRODUÇÃO ...........................................................................................................................

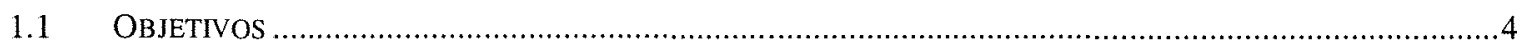

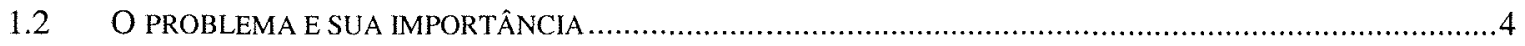

2 EXPANSÃO AGRÍCOLA BRASILEIRA, DESENVOLVIMENTO DA INFRA-ESTRUTURA DE

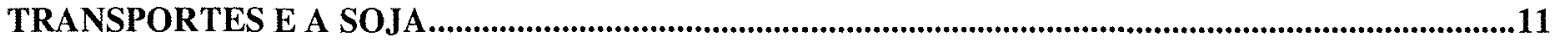

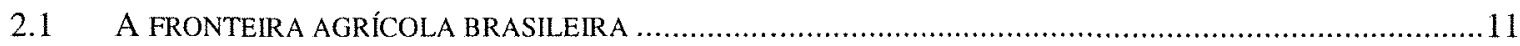

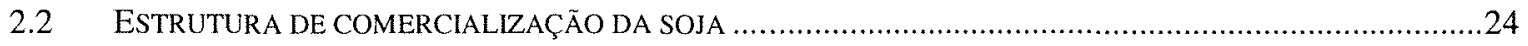

2.3 ESTRUTURAS DE TRANSPORTE ATUAL E EM DESENVOLVIMENTO NO NORTE, CENTRO-OESTE E

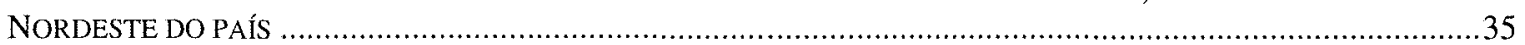

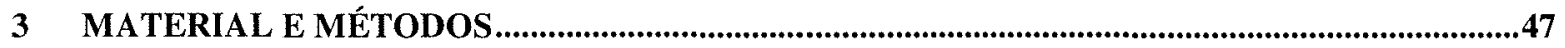

3.1 FORMALIZAÇÃO DA TEORIA DE USO DA TERRA DE VON THÜNEN ……..........................................

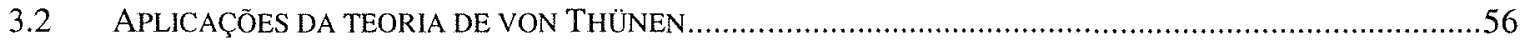

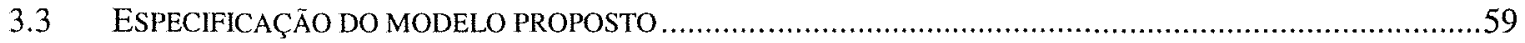

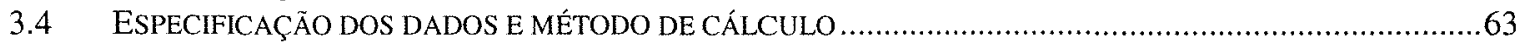

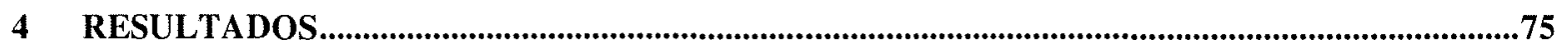

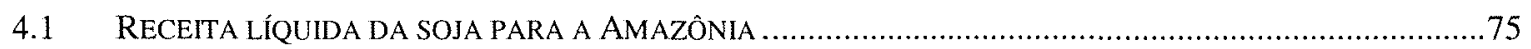

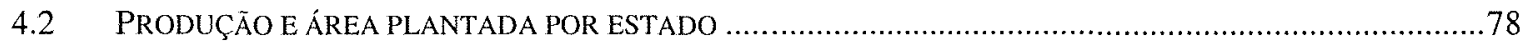

4.3 PRODUÇÃO E ÁREA PLANTADA POR TIPO DE VEGETAÇÃO ANTERIOR À SOJA ...................................82

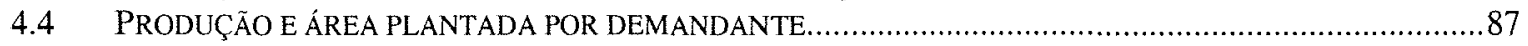

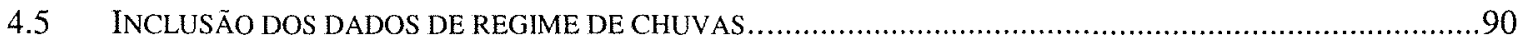

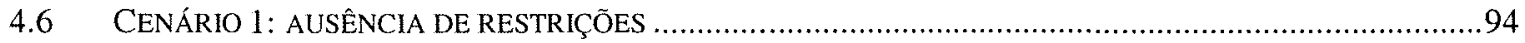

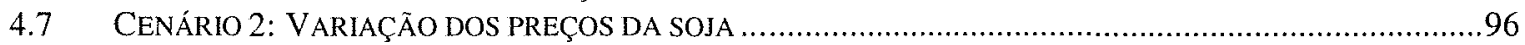

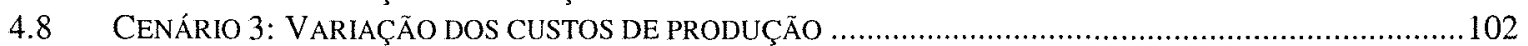

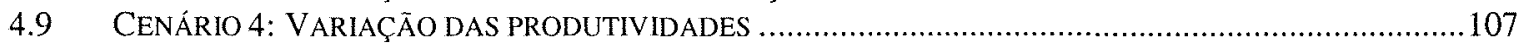

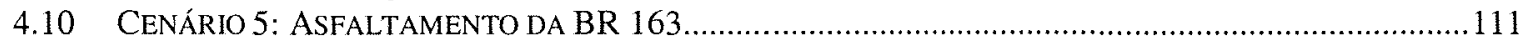

4.11 CENÁRIO 6: AUMENTO DE 10\% NOS FRETES RODOVIÁRIOS ......................................................115

4.12 CENÁRIO 7: DESCONSIDERAÇÃO DAS ÁREAS COM AREIA QUARTZOSA ….....................................119

4.13 CENÁRIO 8: AUMENTO DA CAPACIDADE DA FERROVIA CARAJÁS E DAS HIDROVIAS .........................121

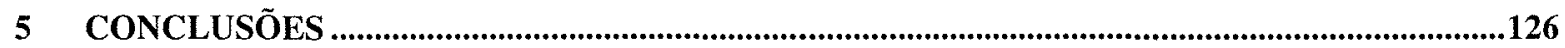

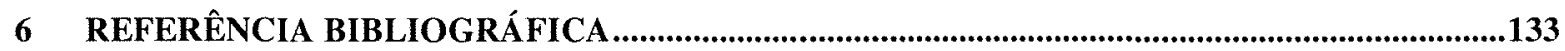

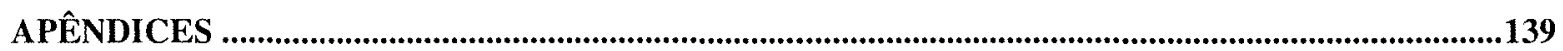


Tabela 1. Custo de produção, custo de frete atual e estimado e custo total atual e estimado para as principais regiões produtoras de soja do Brasil, 1998.

Tabela 2. Composição de custos médios da soja, 1997

Tabela 3. Frete marítimo de grãos em 1985 e em um mercado com fretes em patamares equivalentes às médias históricas para portos selecionados, em US\$ / $t$.

Tabela 4. Estimativa das áreas aptas para a agricultura em cada estado do país, em milhares de hectares.. 14

Tabela 5. Comparação dos trabalhos que projetaram a demanda pela soja brasileira para os próximos anos

Tabela 6. Estimativas de produção de soja por estado e participação no total produzido. 17

Tabela 7. Efeito-substituição atribuído à soja no Brasil, 1968-1989, em hectares

Tabela 8. Exportações dos principais produtos do complexo soja por estado brasileiro, em equivalente grão, 1997 e 1998.

Tabela 9. Capacidade instalada de processamento de soja por empresa e estado, 1997.

Tabela 10. Capacidade de esmagamento de soja da indústria brasileira por estado, 1995 - 1999, em toneladas / dia.....

Tabela 11. Principais rotas para a soja em grão, 1995.

Tabela 12. Procedimento de cálculo para paridade do preço da soja em Chicago para Rondonópolis (MT), maio de 1998.

Tabela 13. Investimentos planejados ou em andamento do Programa "Brasil em Ação", em milhões de reais

Tabela 14. Investimentos previstos para 2000 para projetos de melhoria de infra-estrutura de transportes pelo Plano Plurianual $2000-2003$

Tabela 15. Custos para transportar produtos agrícolas por caminhão (US\$/km) sobre diferentes tipos de estradas na Amazônia Oriental, 1998.

Tabela 16. Momentos de transporte mínimo, médio e máximo no Brasil para alguns produtos selecionados, em $R \$ / t \cdot k m$, julho de 1998.

Tabela 17. Tópicos principais dos trabalhos do periodo de 1991 a 1999 que utilizam sistema de informação geográfica como ferramenta, segundo o sistema de busca "Web of Science".

Tabela 18. Valores obtidos no processo de incorporação das restrições aos resultados.....

Tabela 19. Participação de cada estado da Amazônia Legal na produção de soja e na área plantada com soja 
Tabela 21. Variação na área desmatada entre 1991 e 1998 separado por estados da Amazônia Legal, em ha.

Tabela 22. Quantidade de soja transportada éarea de influência de cada porto ou agroindústria da Amazônia Legal.

Tabela 23. Total de área abrangida do cenário base por cada uma das faixas de pluviosidade anual.

Tabela 24. Produção potencial a ser transportada e área de influência de cada porto ou agroindústria da Amazônia Legal, considerando o cenário base sem nenhuma restrição de carga.....

Tabela 25. Valores de produção e área plantada considerando uma redução e um aumento de $10 \%$ nos preços da soja nos portos, considerando os parâmetros do cenário base.

Tabela 26. Variação nos valores de produção e área plantada considerando uma redução e um aumento de $10 \%$ nos preços da soja nos portos, separado por estado.

Tabela 27. Variação nos valores de produção e área plantada considerando uma redução e um aumento de $10 \%$ nos preços da soja nos portos, separado por tipo de vegetação anterior à soja.

Tabela 28. Produção e área plantada considerando uma redução e um aumento de $10 \%$ nos custos de produção da soja, separado por estado.

Tabela 29. Variação na produção e área plantada considerando uma redução e um aumento de $10 \%$ nos custos de produção da soja, separado por estado.

Tabela 30. Variação nos valores de produção e área plantada considerando uma redução e um aumento de $10 \%$ nos custos de produção da soja, separado por tipo de vegetação anterior à soja.

Tabela 31. Produção e área plantada considerando uma redução e um aumento de $10 \%$ nas produtividades da soja, separado por estado.

Tabela 32. Produção e área plantada considerando uma redução e um aumento de $10 \%$ nas produtividades da soja, separado por estado.

Tabela 33. Variação nos valores de produção e área plantada considerando uma redução e um aumento de $10 \%$ nas produtividades da soja, separado por tipo de vegetação anterior à soja.

Tabela 34. Produção e área plantada da soja considerando o asfaltamento da BR 163, separado por estado.

Tabela 35. Variação na produção e área plantada da soja considerando o asfaltamento da BR I63, separado por estado.

Tabela 36. Variação nos valores de produção e área plantada da soja considerando o asfaltamento da BR 163, separado por tipo de vegetação anterior à soja.

Tabela 37. Produção e área plantada considerando um aumento de $10 \%$ nos fretes rodoviários, separado por estado.

Tabela 38. Variação na produção e na área plantada em relação ao cenário base considerando uma redução e um aumento de $10 \%$ nos fretes rodoviários, separado por estado.

Tabela 39. Variação nos valores de produção e área plantada considerando um aumento de $10 \%$ nos fretes rodoviários, separado por tipo de vegetação anterior à soja. 
Tabela 40. Redução nos valores de produção e área plantada por estado desconsiderando os solos Areia Quartzosa e variação com relação ao cenário base.

Tabela 41. Variação da produção e área por corredor em relação ao cenário base, considerando o aumento na capacidade de transporte da ferrovia do Carajás e das hidrovias.

Tabela 42. Área total com receita líquida alterada devido ao aumento na capacidade de transporte das vias.

Tabela 43. Área plantada com soja em cada estado da Amazônia Legal segundo os resultados do cenário base e dos cenários pessimistas.

Tabela 44. Área plantada com soja em cada estado da Amazônia Legal segundo os resultados do cenário base e dos cenários otimistas.

Tabela 45. Área plantada com soja em cada vegetação da Amazônia Legal segundo os resultados do cenário base e dos cenários otimistas.

Tabela 46. Área plantada com soja sobre cada tipo de vegetação da Amazônia Legal segundo os resultados do cenário base e dos cenários pessimistas. 


\title{
AVALIAÇÃO DO POTENCIAL DE EXPANSÃO DA SOJA NA AMAZÔNIA LEGAL: UMA APLICAÇÃO DO MODELO DE VON THÜNEN
}

\author{
Autor: Fabiano Guimarães Costa \\ Orientador: José Vicente Caixeta Filho
}

\begin{abstract}
RESUMO
O governo brasileiro tem proposto grandes projetos de infra-estrutura de transportes em algumas das principais vias das regiões Centro-Oeste e Norte. Estes projetos têm a intenção explícita de melhorar o escoamento da produção do Centro-Oeste e estimular a expansão da área plantada de soja no país, deslocando esta fronteira cada vez mais para o norte. No entanto, estas áreas apresentam estrutura básica precária, contando com deficiências nos setores energéticos e de transportes, o que prejudica a produção agrícola comercial. Mesmo a viabilidade técnica da produção é questionada, devido à alta pluviosidade, deficiência dos solos e inexistência de variedades adaptadas à região. Observa-se também um potencial conflito entre a intenção de produzir e desenvolver a região Norte, e a de preservar a maior floresta tropical do mundo, além do potencial conflito por terras indígenas, comunitárias e unidades de conservação decorrente do desenvolvimento da região. Nesse sentido, com o apoio de Sistemas de Informações Geográficas, foram analisados dados geo-referenciados da Amazônia Legal. Os resultados em forma de mapas, ilustram o alcance econômico da soja, que sobrepostos com outros mapas (como áreas com grande riqueza de biodiversidade ou identificação de pólos consumidores dos produtos de soja), contribuem para a elaboração de políticas públicas e estratégias comerciais para o desenvolvimento sustentável da Amazônia.
\end{abstract}

Palavras-chave: logística, soja, Amazônia Legal, Sist. de Informações Geográficas.

\section{ANALYSIS OF THE SOYBEAN'S POTENTIAL OF EXPANSION IN THE BRAZILIAN AMAZON: AN APPLICATION OF VON THÜNEN'S MODEL}

Author : Fabiano Guimarães Costa

Adviser: José Vicente Caixeta Filho

\begin{abstract}
The Brazilian Government has been proposing large investment projects aiming at improving the transportation infrastructure of the Central-West and North regions. These projects intend explicitly to develop the delivery system in the Central-West, which stimulates the soybean expansion to Northern areas. However, basic infrastructure (energy and transportation, mainly) in these new areas are important bottlenecks for commercial agriculture, such as soybean. Even some technical question marks are remaining, once wet weather, poverty of soils and lack of adequate soybean varieties could reduce the viability of soybean in the Legal Amazon. There is, also, a potential for conflicts between the desire of producing commercial crops and preserving the largest tropical forest in the world. This paper intends to help in this discussion as well in the analysis of geo-referenced data from Legal Amazon, using a Geographic Information System (GIS), incorporating a linear programming model developed to find out where in the Legal Amazon the soybean crop would be economically viable. The results obtained were compared to other mapped data (such as type of vegetation, type of soils, among others) and can help in developing public policies for a sustainable development of the Amazon.
\end{abstract}

Key words: logistics, soybean, Legal Amazon, Geographic Information System 


\section{INTRODUÇÃO}

A produção de grãos brasileira tem evoluído nas últimas décadas no sentido de se deslocar para áreas cada vez mais distantes dos grandes centros do Sudeste e Sul do país. Com a viabilização técnica da produção comercial nos cerrados e a abertura de estradas, a soja modificou significativamente a paisagem da região Centro-Oeste, sendo o pivô do desenvolvimento naquela região. Este desenvolvimento tem contribuído para a melhoria da infra-estrutura, permitindo o acesso a regiões cada vez mais distantes.

Atualmente, o governo brasileiro tem proposto projetos de grande porte no sentido de melhoria da infra-estrutura de transporte de algumas das principais vias das regiões Centro-Oeste e Norte. Estes projetos têm a intenção explícita de permitir um melhor escoamento da produção do Centro-Oeste e estimular a expansão da área plantada de soja no país, deslocando esta fronteira cada vez mais para o norte.

Além do mais, os Planos Plurianuais do governo federal, também chamados de "Brasil em Ação" e "Avança Brasil", modificam a direção do escoamento da produção, alterando as rotas de norte-sul para sul-norte, envolvendo portos mais próximos dos países importadores.

Com isso, muitos investidores estão interessados em incorporar áreas da região amazônica no processo produtivo, pois são as que apresentam menores preços e menores distâncias aos portos de exportação, como observa-se na região da Chapada dos Parecis (MT). Esta região reduziu a utilização do transporte exclusivamente rodoviário até o porto de Paranaguá (PR), percorrendo 2.201 km, e mais 14.000 km até Roterdan, para um sistema multimodal (rodovia e hidrovia do rio Madeira) que tem como destino o porto de Itacoatiara (AM) (percorrendo, neste caso, $1.881 \mathrm{~km}$ de rodovia até Porto Velho e mais $1.115 \mathrm{~km}$ pela hidrovia do rio Madeira, num total de $2.996 \mathrm{~km}$ ). Nesta nova rota o caminho marítimo é menor, totalizando apenas $11.000 \mathrm{~km}$ até Roterdan. Este novo percurso, além de reduzir o trajeto, também reduziu o custo total pela utilização do modal hidroviário.

No entanto, estas áreas apresentam estrutura básica precária, contando com deficiências nos setores energéticos e de transportes, o que prejudica a produção agrícola 
comercial. Mesmo a viabilidade técnica da produção é questionada, devido à alta pluviosidade, deficiência dos solos e inexistência de variedades adaptadas à região.

Observa-se também um potencial conflito entre a intenção de produzir e desenvolver a região Norte, e a de preservar a maior floresta tropical do mundo, além do potencial conflito por terras indígenas, comunitárias e parques nacionais, decorrentes do desenvolvimento da região.

Desta forma, é necessário que se formulem políticas que viabilizem o desenvolvimento da região Norte (baseado primeiramente na agricultura comercial), sem sobrepujar os interesses ambientais da sociedade, nem os direitos das populações tradicionais amazônicas. Com isso, este trabalho pretende contribuir nesta discussão, levantando informações que permitam uma melhor identificação das áreas da Amazônia que sofrerão maior pressão para a conversão em agricultura comercial, além de medir quais os impactos dos projetos de investimento governamentais e privados na expansão da soja nesta que é a última fronteira agrícola brasileira.

Neste sentido, será utilizada como arcabouço teórico a abordagem inicialmente proposta por Johann Heinrich von Thünen, em 1826, que dizia respeito à elaboração de um modelo que vem servindo de base para as teorias de localização, relacionando custo de transporte com as diferenças na utilização da terra. Este autor utilizou um cenário bastante simples para mostrar que em áreas próximas do mercado consumidor as terras tendem a ter uma maior competição pelo seu uso e, assim, predominam atividades de maior rentabilidade por unidade de área (uma vez que o custo de transporte neste caso é menos importante pois a distância a ser percorrida é pequena). Com o aumento da distância em relação ao mercado, os custos de transporte tendem a aumentar para estas atividades, reduzindo sua competitividade. Assim, a atividade predominante em uma determinada área vai ser a que obtiver a maior rentabilidade considerando o custo de transporte, o que indica que atividades altamente rentáveis tendem a se situar mais próximas dos centros consumidores. Por outro lado, uma outra atividade qualquer que venha a ter custos de transporte menores, passará a se tornar mais rentável a partir de um determinado ponto, pois sua rentabilidade menos o custo de transporte será menor que o da primeira atividade. Os limites que separam estas duas atividades são conhecidos como os anéis de von Thünen. 
Este referencial teórico é considerado adequado para este trabalho pois o alcance econômico da soja na região Amazônica dependerá fortemente dos novos corredores de transporte planejados pelos Planos Plurianuais do governo federal.

\subsection{Objetivos}

Este trabalho tem como principal objetivo avaliar o potencial das diversas microrregiões da Amazônia para a agricultura comercial nos próximos anos, através do estudo da viabilidade técnica e econômica da cultura da soja em novas áreas da região, com o auxílio do modelo de von Thünen.

Como objetivos específicos, pretende-se:

- identificar o atual estágio da produção de soja nas regiões de fronteira agrícola do Norte do país;

- levantar os custos de transporte para os principais corredores do Norte do país;

- mapear as regiões viáveis técnica e economicamente para a produção de soja na Amazônia;

- avaliar o impacto dos projetos de melhoria da infra-estrutura planejados para o Norte do país na expansão da soja.

\subsection{O problema e sua importância ${ }^{1}$}

A soja e seus derivados têm se constituído como importantes produtos agrícolas da pauta de exportação brasileira. As vantagens brasileiras para a produção desta oleaginosa estão relacionadas com a farta disponibilidade de terras baratas, alta produtividade e mãode-obra barata. Isto é mais característico para as regiões de expansão mais recente, como são os casos das regiões Centro-Oeste e Nordeste.

Devido às suas características naturais e ao alto nível de tecnologia adotado, estas novas regiões apresentam custos de produção e produtividade de grãos semelhantes às dos Estados do Sul e Sudeste (Tabela 1), mas apresentam vantagens com relação aos teores de óleo do grão e de proteína do farelo, o que gera a preferência de alguns compradores do mercado externo para o grão e o farelo destas regiões frente aos concorrentes do Sul.

\footnotetext{
${ }^{1}$ Algumas informações apresentadas nesta seção, referentes às melhorias na infra-estrutura de transporte e ao atual estágio da expansão da soja na Amazônia, foram coletadas nas visitas de campo realizadas pelo autor durante o período de setembro a outubro de 1999.
} 
No entanto, o diferenciador negativo das regiões de cerrado é a grande distância que os produtos percorrem para chegar ao seu mercado consumidor, além do tipo de modal utilizado, reduzindo substancialmente esta vantagem inicial.

Pela Tabela 1 pode-se notar também que se o custo de transporte for reduzido substancialmente (o que seria possível com a conclusão dos projetos de investimento em infra-estrutura de transporte atualmente previstos), as regiões de cerrado do Brasil seriam extremamente competitivas frente aos outros estados do país.

Tabela 1. Custo de produção, custo de frete atual e estimado e custo total atual e estimado para as principais regiões produtoras de soja do Brasil, 1998.

\begin{tabular}{|c|c|c|c|c|c|}
\hline $\begin{array}{l}\text { Município / } \\
\text { Estado }\end{array}$ & $\begin{array}{l}\text { Custo de } \\
\text { produção } \\
\text { (US\$ / t) } \\
\text { (1) }\end{array}$ & $\begin{array}{l}\text { Frete rodoviário } \\
\text { atual até o porto } \\
\text { (US\$ / t) } \\
(2)\end{array}$ & $\begin{array}{c}\text { Frete } \\
\text { multimodal } \\
\text { até o porto } \\
\text { (US\$ / t) } \\
(3)\end{array}$ & $\begin{array}{l}\text { Custo total } \\
\text { atual até o } \\
\text { porto } \\
\text { (US\$ / t) } \\
(4)\end{array}$ & $\begin{array}{c}\text { Custo total } \\
\text { estimado até o } \\
\text { porto (US\$ / t ) }\end{array}$ \\
\hline Maranhão & 167.60 & & & & \\
\hline Balsas & 167.60 & - & 29.96 & - & 197.56 \\
\hline Mato Grosso & 156.52 & & & & \\
\hline $\begin{array}{l}\text { Campo Novo dos } \\
\text { Parecis }\end{array}$ & 152.53 & 55.08 & 56.50 & 207.61 & 209.03 \\
\hline Sapezal ${ }^{\star \star}$ & 152.53 & 70.34 & 48.56 & 222.87 & 201.09 \\
\hline $\begin{array}{l}\text { Primavera do } \\
\text { Leste }\end{array}$ & 157.37 & 44.30 & 32.00 & 201,67 & 189,37 \\
\hline Rondonópolis & 161.00 & 43.00 & 27.00 & 204.00 & 188.00 \\
\hline Sorriso ${ }^{\star \star \star}$ & 157.44 & 55.55 & 39.00 & & \\
\hline Paraná & 160.09 & & & & \\
\hline Cascavel & 159.31 & 24.64 & 24.65 & 183.95 & 183.96 \\
\hline Londrina & 160.96 & 25.62 & 23.50 & 186.58 & 184.46 \\
\hline São Paulo & 186.37 & & & & \\
\hline Cândido Mota & 210.35 & 20.00 & - & 230.35 & - \\
\hline Orlândia & 172.90 & 18.01 & - & 260.91 & - \\
\hline
\end{tabular}

Fontes: (1) FNP (1999) (dados originais em US\$); (2) frete em R\$ do SIFRECA convertidos com o câmbio médio do mês do frete cotado e (3) Lício \& Corbucci (1996), dados de campo ou estimativa do autor (dados originais em US\$).

* Para Balsas, o porto utilizado foi o de Itaqui (MA). Campo Novo dos Parecis e Sapezal utilizavam Santos (SP) e utilizam o porto de Itacoatiara (AM). Primavera do Leste e Rondonópolis utilizam Santos (SP). Sorriso utiliza Santos (SP) e utilizará Santarém (PA). Cascavel e Londrina utilizam Paranaguá (PR) e Cândido Mota e Orlândia utilizam Santos (SP).

** O custo de produção de Sapezal foi estimado como sendo o mesmo de Campo Novo dos Parecis.

*** A opção considerada neste exercício foi apenas o asfaltamento da BR163. Caso a hidrovia do Teles PiresJuruena-Tapajós seja concluída, este custo deve baixar ainda mais.

Os dados da Tabela 1, no entanto, devem ser considerados apenas como um exercício, pois são de diversas fontes e podem apresentar incompatibilidades entre si. Eles mostram, no entanto, que o Paraná é um estado mais competitivo que as regiões de cerrado. Porém, nestes cálculos não está sendo considerado o diferencial de produtividade destas 
duas regiões. Além disso, a melhoria na infra-estrutura não apenas reduzirá o frete do produto final, como também diminuirá o custo de produção, pois disponibilizará insumos a custos mais baixos. Um outro fator importante é que as regiões dos cerrados analisadas são as mais distantes dos portos do norte do país, sendo que novas áreas devem ser incorporadas ao processo produtivo com muito mais competitividade. Assim, os ganhos que a região de cerrados terá com a melhoria da infra-estrutura tendem a torná-la a principal região produtora de grãos do país num curto espaço de tempo.

Já com relação aos outros países (Argentina e Estados Unidos, principalmente), o Brasil como um todo apresenta vantagens de custo de produção. Lazzarini \& Nunes (1998) citam que os custos de produção nacionais são US\$20.00/t a US\$ $30.00 / \mathrm{t}$ menores que os americanos, sendo esta diferença também observada por Caixeta Filho (1998).

No entanto, nos custos de comercialização o Brasil perde esta vantagem (Tabela 2). Isto se deve principalmente ao modal utilizado, à distância percorrida, à ineficiência portuária e à diferença dos custos marítimos. No Brasil, o transporte de longas distâncias é feito através de rodovias, enquanto nos Estados Unidos transporta-se este grão principalmente por hidrovias.

Tabela 2. Composição de custos médios da soja, 1997

\begin{tabular}{lcc}
\hline Valor $($ US $\$ / \mathrm{t}$ ) & Estados Unidos & Brasil \\
\hline Custo de Produção & 222 & 192 \\
Frete e armazenagem regional & 10 & 18 \\
Frete até os portos & 10 & 40 \\
Custo portuário & 3 & 8 \\
Frete marítimo até Roterdan & 15 & 25 \\
\hline TOTAL & 260 & 283 \\
\hline
\end{tabular}

Fonte: Caixeta Filho (1998)

Além disso, devido às ineficiências operacionais, os portos nacionais apresentam custos bem maiores (Ferreira et al., 1993, chegaram a observar um custo quatro vezes maior para a movimentação de cargas nos portos brasileiros, em comparação com os americanos). Pavan (1997) cita como fatores de ineficiência dos portos brasileiros a baixa produtividade nas operações de transferência de mercadorias, o excesso de regulamentação, a deficiente política de pessoal e a reduzida participação da iniciativa privada nos investimentos necessários. 
Por fim, os custos marítimos brasileiros também são mais elevados devido, principalmente, às maiores distâncias dos portos de destino. Figueiredo (1985) apresenta um estudo comparativo dos fretes marítimos dos vários portos das Américas (Tabela 3).

Tabela 3. Frete marítimo de grãos em 1985 e em um mercado com fretes em patamares equivalentes às médias históricas para portos selecionados, em US\$ / t

\begin{tabular}{lcccc}
\hline \multicolumn{1}{c}{ Destino: } & \multicolumn{2}{c}{ Mercado de fretes em 1985 } & \multicolumn{2}{c}{ Mercado de fretes recuperado $^{2}$} \\
\hline $\begin{array}{l}\text { Japão } \\
\text { Origem: }\end{array}$ & $\begin{array}{c}\text { Europa } \\
\text { (Roterdan) }\end{array}$ & $\begin{array}{c}\text { Japão } \\
\text { (Yokohama) }\end{array}$ & $\begin{array}{c}\text { Europa } \\
\text { (Roterdan) }\end{array}$ \\
\hline $\begin{array}{l}\text { Bahia Blanca } \\
\text { (Arg.) }\end{array}$ & 23.5 & 16.0 & 34.5 & 23.5 \\
$\begin{array}{l}\text { Paranaguá / } \\
\text { Rio Grande }\end{array}$ & 20.5 & 12.5 & 29.0 & 18.0 \\
$\begin{array}{l}\text { Nova Orleans } \\
\text { (EUA) }\end{array}$ & 15.0 & 9.0 & 22.0 & 12.5 \\
$\begin{array}{l}\text { Vancouver } \\
\text { (Canadá) }\end{array}$ & 9.0 & - & 15.0 & - \\
\hline
\end{tabular}

Fonte: Figueiredo (1985)

1- custo diário de US $\$ 6,000.00$ a US $\$ 7,000.00$ para navios Panamax (60 / 75.000 TPB)

2- custo diário de US\$12,000.00 a US $\$ 13,000.00$ para navios Panamax (60 / 75.000 TPB)

3- com operação de up-river (carregamento parcial nos portos do Rio Paraná e Rio da Prata)

Nota-se que os portos nacionais têm uma desvantagem de US\$3.50 / $\mathrm{t}$ a US\$ $5.50 /$ t para Roterdan e US\$ 5.50 / t a US\$ 7.00 / t para Yokohama em relação à Nova Orleans, relacionada principalmente à diferença de tempo de navegação. No entanto, os argentinos têm uma desvantagem ainda maior. No caso do transporte para o Japão, o Brasil tem a vantagem de não necessitar passar pelo Canal do Panamá, o que permite o transporte de navios de capacidades maiores que o Panamax (no entanto, para o transporte de grãos esta vantagem não é relevante). Para a Europa, por outro lado, esta vantagem não existe (Figueiredo, 1985)

Assim, no porto de destino, a soja americana acaba tendo um custo total inferior ao da soja brasileira, além de ser mais competitiva no mercado internacional.

Para reverter este quadro, muitos investimentos estão sendo realizados tanto pelos governos federal e estaduais quanto pela iniciativa privada, com o intuito de mudar o sentido do escoamento dos grãos (diminuindo a distância até o mercado consumidor no exterior) e utilizando modais diferentes do rodoviário. 
Estes novos corredores passam por regiões pouco desenvolvidas, como o estado do Tocantins, o sudoeste do Pará e o sul do Amazonas, que tendem a sofrer uma forte pressão no sentido de investimentos e colonização nos próximos anos. No entanto, são regiões também de grande interesse ambiental, com grandes áreas naturais conservadas e de biodiversidade bastante alta, e que necessitam de um planejamento adequado para $o$ desenvolvimento.

Atualmente, várias novas regiões já apresentam agricultura comercial na região chamada Amazônia Legal, principalmente ligadas a algum corredor importante. O Estado do Tocantins é o de maior potencial de crescimento, pois fica numa posição estratégica (é cortado pela Belém-Brasília e pelo rio Tocantins, sendo seu limite, a oeste, o rio Araguaia) e apresenta condições edafo-climáticas adequadas para a produção de grãos. Os principais pólos deste estado são Pedro Afonso e Campos Lindos, no caso da soja, e Formoso do Araguaia para arroz irrigado. No entanto, as regiões de Mateiros, Dianópolis e Taguatinga (região sudeste do estado) e Guaraí (região central) têm um grande potencial de crescimento com o início da hidrovia do Tocantins.

A região de Balsas (MA) e Uruçuí (PI) já estão se consolidando como pólos produtores de grãos, com um crescimento da produção de cerca de $20 \%$ ao ano. A expansão nesta região se dará no sentido sul, ou seja, chegando ao extremo sul do estado do Piauí. Com isso, no futuro, seria criado um corredor agrícola que interligaria os pólos de Balsas (MA) e Barreiras (BA).

Todas estas regiões anteriormente citadas se localizam em áreas de cerrado e continuam a expansão iniciada nas décadas de 70 e 80 . No entanto, existem novas regiões de cerrado distantes destas regiões de crescimento tradicionais onde a produção de grãos, basicamente soja, está sendo estudada e plantios experimentais já estão sendo realizados, como no Sul do Pará (tendo como pólo Redenção), Alenquér e Monte Alegre (PA), Humaitá (AM), Boa Vista (RR) e Vilhena (RO).

No entanto, já se observa a introdução da produção agrícola em áreas onde a vegetação predominante é a floresta umbrófila densa. Isto pode ser observado nas regiões de Paragominas (PA), Sinop (MT), Querência (MT), Itacoatiara (AM) e Santarém (PA). 
Atualmente estas regiões produzem principalmente arroz e milho, mas a intenção é a introdução da soja. A produção de soja ainda é problemática devido à necessidade de desenvolvimento de tecnologia, uma vez que a quantidade e a freqüência das chuvas exigem que o plantio seja feito entre janeiro e março, diferentemente do restante do país em que o período de plantio é de outubro a dezembro. Além disso, para não colher ainda na época das chuvas (que vai até final de abril e começo de maio), é necessário o desenvolvimento de variedades de ciclo longo (140 dias), enquanto o restante do país utiliza variedades de ciclo curto (110 dias).

Destaca-se também que em Sinop (MT), Cerejeiras (RO) e Itacoatiara (AM), o processo de expansão da fronteira agrícola é diferenciado. Observa-se nestas regiões a introdução da agricultura diretamente após a derrubada da floresta (sem a etapa intermediária das pastagens). Apesar de isto ser considerado antieconômico na maioria das situações (o custo de desmatamento gira em torno de $R \$ 1.500,00 /$ ha), estas regiões têm características especiais que permitem este processo.

O caso de Sinop é peculiar, pois a base da economia do município é a extração madeireira, que está em crise devido à escassez de matéria-prima. Com isto, os madeireiros capitalizados passaram a investir na agricultura como a melhor alternativa econômica, já que existe a perspectiva do asfaltamento da BR 163 (Cuiabá - Santarém), o que deve aumentar significativamente o preço da soja na região.

Cerejeiras é um município onde predominam pequenas propriedades com poucas áreas abertas para a agropecuária. A presença da Sementes Maggi como compradora de soja, pagando preços aparentemente altos para a região, tem incentivado estes pequenos produtores a derrubarem a floresta para a produção de soja.

Em Itacoatiara, o Grupo Maggi tem uma atuação mais direta, tendo arrendado 300 ha para o início da produção na safra 1999/2000, com o intuito principal de mostrar a viabilidade de produção nesta região. Algumas destas áreas foram desmatadas para o plantio e a previsão é expandir o plantio para 2.000 ha nos próximos anos. 
É importante ressaltar, no entanto, que estes desmatamentos aparentemente não são ilegais, uma vez que estão dentro dos $20 \%$ da área permitidos para o desmatamento. Além disso, as áreas abertas são cobertas por floresta secundária, ou seja, floresta que já sofreu ação antrópica, com árvores de diâmetros pequenos e com madeira sem valor comercial. Por outro lado, são áreas que abrigam uma importante biodiversidade e recursos florestais utilizados pelos habitantes destas regiões.

Assim, este novo paradigma para a expansão da fronteira agrícola poderá ser observado em outras regiões que tiverem estas mesmas características, ou seja, florestas se esgotando de madeiras comerciais, empresários capitalizados interessados no desenvolvimento agrícola da região e incentivos para a produção agrícola (na forma de um novo corredor de escoamento, incentivos fiscais ou estímulo de empresas compradoras).

Nota-se, portanto, que o desenvolvimento da agricultura comercial no Norte do país já é uma realidade e tende a crescer a altas taxas nos próximos anos, sendo necessário um estudo aprofundado sobre a viabilidade técnica e econômica destas áreas. Neste sentido, este estudo pretende entender o quadro atual do desenvolvimento da infra-estrutura de transportes da região Norte e Centro-Oeste e identificar quais seriam as regiões onde a pressão para o desenvolvimento (caracterizado neste caso pela cultura da soja) será maior.

Para atingir tais objetivos, este trabalho está organizado da seguinte forma: no próximo capítulo se caracterizará o processo de ocupação das fronteiras agrícolas brasileiras, a estrutura atual de comercialização da soja no Brasil, com foco maior no Centro-Oeste e a infra-estrutura de transportes atual e planejada para as regiões Norte e Centro-Oeste, que viabilizariam o desenvolvimento destas regiões. No capítulo 3 apresentase a metodologia a ser utilizada para o tratamento do problema, seguida pela análise dos resultados (capítulo 4) e pelas conclusões e recomendações de novos trabalhos (capítulo 5). 


\section{EXPANSÃO AGRÍCOLA BRASILEIRA, DESENVOLVIMENTO DA INFRA-ESTRUTURA DE TRANSPORTES E A SOJA²}

A chegada da soja à Amazônia é mais uma etapa do processo de desenvolvimento da agricultura brasileira, que esteve sempre fortemente relacionado à expansão da área agrícola. Neste processo, as regiões envolvidas acabam tendo não só um desenvolvimento econômico marcante, mas também uma relação mais intensa com outros mercados, o que se deve, pelo menos parcialmente, ao desenvolvimento da infra-estrutura de transportes da região.

Assim, para se avaliar o desenvolvimento da soja na Amazônia faz-se necessário o entendimento do processo de expansão agrícola brasileiro e como ele está relacionado ao desenvolvimento dos sistemas de transportes (seção 2.1). Em seguida será descrita a estrutura de comercialização da soja, identificando as principais diferenças entre as diversas regiões produtoras e como os custos de transporte influenciam na formação dos seus preços (seção 2.2). Por fïm, serão descritos os vários projetos de investimento em transportes planejados para as regiões Norte e Centro-Oeste e que direcionarão o desenvolvimento destas regiões (seção 2.3 )

\subsection{A fronteira agrícola brasileira}

A expansão da fronteira agrícola brasileira passou, nas últimas décadas, por várias fases distintas. Na década de 40 a expansão se deu para o oeste do Paraná e São Paulo, sendo esta a chamada fronteira tradicional. Este movimento teve como principal motivação o crescimento da cultura do café, aproveitando as áreas de bons solos ainda desocupadas nestas regiões (Dutra, 1993).

Já na década de 50 e 60 iniciou-se a corrida para o Centro-Oeste, sendo ocupadas primeiramente as regiões do Mato Grosso do Sul, sul de Goiás e Distrito Federal. O incentivo governamental foi o grande motivador desta ocupação, uma vez que nesta época

\footnotetext{
${ }^{2}$ Algumas informações apresentadas nas três seções deste capítulo a respeito da evolução atual da fronteira agrícola e das melhorias na infra-estrutura de transporte no Norte e Centro-Oeste do país foram coletadas durante as visitas de campo realizadas pelo autor no período de setembro a outubro de 1999.
} 
deu-se a construção de grandes projetos de infra-estrutura, como a rodovia Belém-Brasília e a própria cidade de Brasília, com a mudança da capital do país para o Centro-Oeste.

A presença do Estado foi ainda mais marcante na década de 70, com a criação de projetos de desenvolvimento regionais, como o PRODOESTE, POLOAMAZÔNIA e POLOCENTRO, além de incentivos fiscais e facilidade de crédito para a produção agrícola. Com isto, a produção de culturas agrícolas para exportação foi tomando espaço, sendo a soja o principal produto (Dutra, 1993). O baixo preço da terra também foi apontado por Guimarães Neto (1997) como um fator para o desenvolvimento da agricultura no Centro-Oeste. No entanto, a ocupação do cerrado só foi possível por conta dos avanços nas pesquisas desenvolvidas para esta região, que viabilizaram tecnicamente a produção da soja através, principalmente, do desenvolvimento de novas variedades adaptadas às condições edafoclimáticas e de latitude, além dos aperfeiçoamentos nas técnicas de correção dos solos (Sousa, 1990).

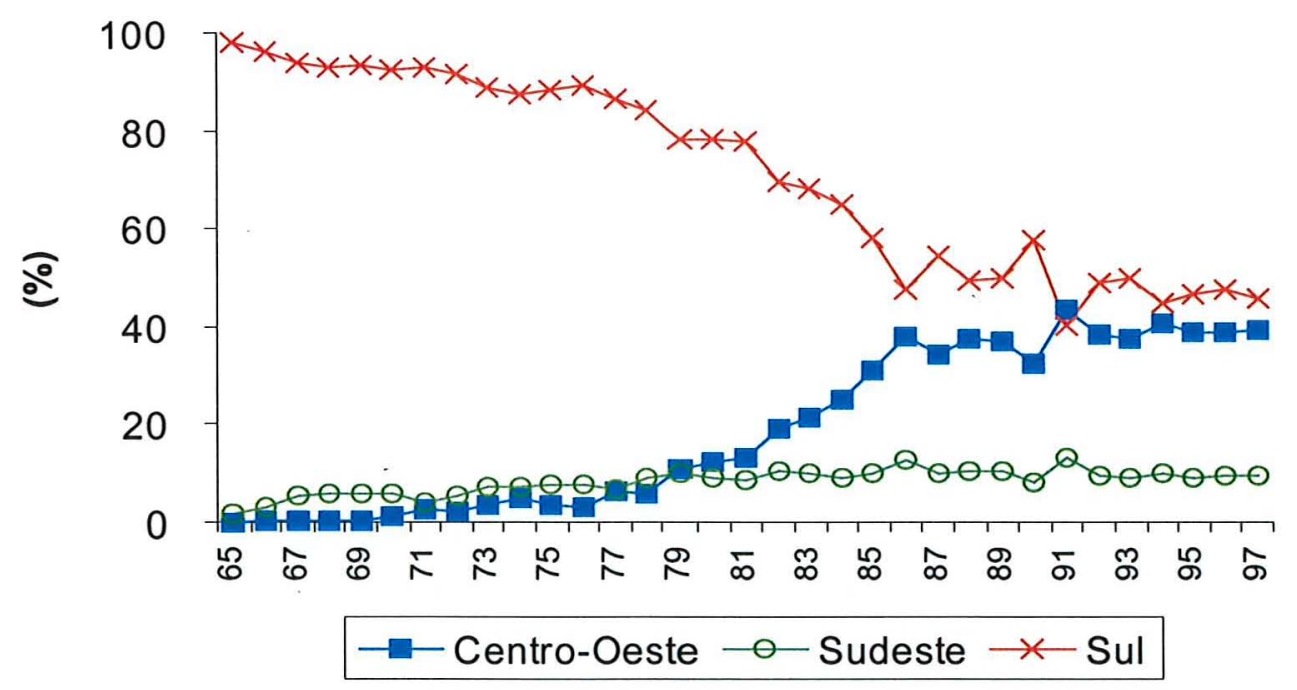

Figura 1. Evolução da participação da produção de soja por região, em relação à produção brasileira, entre 1965 e 1997.

Fonte: Marques \& Sousa (1998), utilizando dados do IBGE

Como pode-se observar pela Figura 1, atualmente o Centro-Oeste é uma das principais regiões produtoras de soja no país, com participação na produção total brasileira próxima à região Sul. Segundo Sousa (1990), esta evolução da região Centro-Oeste na participação da produção nacional se deveu a dois fatores principais: primeiro o 
crescimento vertiginoso da produção dos cerrados a partir de 1979 e, segundo, a redução no ritmo do crescimento (e em alguns anos a retração) da produção na região Sul.

A soja produzida na região Centro-Oeste, desde o início, está baseada na formação de médias e grandes propriedades e na utilização de técnicas modernas de produção com pouca utilização de mão-de-obra (Dutra, 1993). Além disso, o processo de concentração fundiária na produção de soja parece ser uma tendência do setor. Em 1980, 37\% da produção vinha de propriedades com 100 ha ou menos, enquanto $25 \%$ vinha de propriedades com mais de 1.000 ha. Já em 1985, apenas $20 \%$ da produção vinha do primeiro grupo, enquanto que $45 \%$ tinha como fonte grandes propriedades (Roessing, 1998, p. 12).

Além da concentração fundiária, o processo de ocupação da fronteira agrícola pressupõe a migração de produtores da região Sul do país, pois estes têm o conhecimento técnico e capital suficiente para viabilizar a produção agrícola em novas áreas. Isto pode ser observado claramente no Mato Grosso, em Rondônia, em Balsas, em Roraima e no Amazonas, sendo que este processo deve continuar em outras regiões. Esta migração faz com que a população local participe em menor intensidade ou seja excluída do desenvolvimento de sua região, contribuindo para o aumento da má distribuição de renda e dos problemas sociais.

Com a consolidação da fronteira do cerrado na década de 90 , a expansão agrícola entra na última fronteira brasileira: a região amazônica. Por região amazônica entende-se as áreas compreendidas na Amazônia Legal, que vem a ser toda a região Norte, o Mato Grosso e o oeste do Maranhão, numa área de $5.217 .423 \mathrm{~km}^{2}$. Nesta grande região encontram-se vários tipos de vegetação, identificados pelo Projeto Radam na década de 70 (Tratado de Cooperação Amazônica, 1996): floresta tropical densa, floresta tropical aberta, cerrado, formações pioneiras, floresta tropical decidual, refúgio ecológico e floresta secundária (resultante de ação antrópica). Nota-se, portanto, que a Amazônia é um complexo de paisagens diferentes, influenciando também nas aptidões de cada área.

Seu potencial para a produção de grãos é imenso. Como pode-se observar pela Tabela 4, a região Norte é a que apresenta a maior área potencial para a expansão do cultivo 
de grãos no país, seguida de perto pelo Centro-Oeste. Em termos individuais, os estados da região Norte não se destacam tanto quanto Mato Grosso, Minas Gerais e Bahia, mas como todos têm áreas significativas passíveis de exploração, no conjunto esta é a região com maior tendência a ceder terras para a agricultura comercial.

Tabela 4. Estimativa das áreas aptas para a agricultura em cada estado do país, em milhares de hectares

\begin{tabular}{|c|c|c|c|}
\hline & $\begin{array}{l}\text { Área apta à } \\
\text { agricultura }\end{array}$ & $\begin{array}{l}\text { Área apta para } \\
\text { grãos }\end{array}$ & $\begin{array}{c}\text { Área potencial } \\
\text { para grãos }\end{array}$ \\
\hline Região Norte & 294.873 & 62.811 & 59.679 \\
\hline RO & 18.644 & 10.600 & 10.289 \\
\hline$A C$ & 13.320 & 6.900 & 6.848 \\
\hline$A M$ & 132.700 & 9.600 & 9.812 \\
\hline RR & 133.283 & 9.811 & 9.788 \\
\hline PA & 90.136 & 11.600 & 9.224 \\
\hline AP & 11.160 & 6.734 & 6.718 \\
\hline TO & 15.630 & 7.560 & 7.000 \\
\hline Região Nordeste & 77.364 & 43.823 & 31.432 \\
\hline MA & 13.600 & 7.347 & 6.122 \\
\hline $\mathrm{PI}$ & 11.700 & 7.442 & 6.691 \\
\hline CE & 5.253 & 2.852 & 1.378 \\
\hline RN & 1.900 & 909 & 301 \\
\hline PB & 1.424 & 926 & 105 \\
\hline PE & 3.908 & 2.008 & 402 \\
\hline AL & 1.879 & 1.287 & 354 \\
\hline SE & 1.100 & 475 & 271 \\
\hline $\mathrm{BA}$ & 36.600 & 18.377 & 15.808 \\
\hline Região Sudeste & 64.350 & 44.145 & 32.550 \\
\hline MG & 39.250 & 25.830 & 20.000 \\
\hline ES & 2.800 & 1.500 & 1.145 \\
\hline RJ & 2.200 & 1.082 & 587 \\
\hline $\mathrm{SP}$ & 20.100 & 15.733 & 10.818 \\
\hline Região Sul & 42.300 & 27.192 & 13.551 \\
\hline PR & 14.500 & 10.492 & 5.050 \\
\hline SC & 7.600 & 3.668 & 1.880 \\
\hline RS & 20.200 & 13.032 & 6.621 \\
\hline Região Centro-Oeste & 103.125 & 59.180 & 52.380 \\
\hline MS & 23.100 & 12.500 & 10.637 \\
\hline MT & 58.300 & 35.100 & 33.109 \\
\hline GO & 21.450 & 11.300 & 8.431 \\
\hline DF & 325 & 280 & 203 \\
\hline TOTAL & 582.012 & 237.151 & 189.592 \\
\hline
\end{tabular}

A diferença entre áreas aptas e potenciais para grãos, segundo Pavan (1997), é a existência de áreas de proteção, ou seja, existem muitas áreas que são tecnicamente aptas à 
produção de grãos, mas estão localizadas em parques nacionais, reservas indígenas, etc. e que legalmente não podem ser utilizadas para a agricultura comercial.

Estas novas áreas serão incorporadas ao processo produtivo bastante rapidamente a partir de melhorias na infra-estrutura de transportes na região. Com essas melhorias, aumenta-se a competitividade das regiões que já produzem (como vimos na Tabela 1), além de se viabilizar áreas até então economicamente inacessíveis para a produção de grãos (como é o caso do estado de Rondônia). Este processo será ainda mais intenso se a demanda pela soja for crescente.

Alguns autores realizaram estimativas para o futuro do mercado de soja, tanto no Brasil quanto no mundo. Pavan (1997) estimou que em 2005 a demanda interna por soja estaria em 13,6 milhões de toneladas, enquanto a demanda para exportação seria de 34,6 milhões de toneladas, totalizando 48,2 milhões de toneladas. Para estes cálculos Pavan (1997) utilizou uma taxa de crescimento do mercado externo de $5 \%$ ao ano para farelo e grãos e $18 \%$ ao ano para o óleo a partir de 1995. Para o óleo no mercado interno, admitiu-se um consumo de $70 \mathrm{~g} / \mathrm{hab} . / \mathrm{dia}$, enquanto que para o farelo e os grãos assumiu-se um crescimento de 1,5\% ao ano para o período de 1995 a 2005.

Roessing (1998), também previu um crescimento para a demanda brasileira de soja, não divergindo da previsão anterior. Este autor utilizou quatro metodologias diferentes e suas previsões para 2005 são de uma demanda total de soja (mercados interno e externo) entre 44,8 e 52,5 milhões de toneladas e para 2010, entre 57,0 e 75,7 milhões de toneladas

Já no trabalho de Sugai et al. (1998), as estimativas para 2005 são mais conservadoras. Estes autores formulam três cenários de crescimento da renda per capita brasileira e chegaram a uma demanda que ficou entre 31,6 e 32,3 milhões de toneladas. Neste caso, os autores utilizaram uma projeção de demanda externa baseada apenas na série temporal de exportações brasileiras, chegando em 2005 com 20,7 milhões de toneladas exportadas. Neste mesmo estudo, estes autores também projetaram a demanda por grãos em cada estado brasileiro. 
Por fim, no trabalho do GEIPOT (1999), estima-se para 2005 uma produção de soja de 34,2 milhões de toneladas, para um esmagamento de 26,2 milhões de toneladas e 6,8 milhões de toneladas destinados à exportação. Para 2015 a produção cresce para 52,8 milhões de toneladas e o consumo para esmagamento e as exportações ficam em 39,9 milhões e 10,4 milhões de toneladas, respectivamente. Neste trabalho também foi estimado o crescimento de área plantada no Brasil, que passa de 10,6 milhões de ha para 16,4 milhões de ha em 2015, ou seja, um crescimento 5,8 milhões de hectares para o cultivo da soja. Na Tabela 5 pode-se visualizar o resumo dos resultados anteriormente descritos.

Tabela 5. Comparação dos trabalhos que projetaram a demanda pela soja brasileira para os próximos anos

\begin{tabular}{|c|c|c|c|c|c|}
\hline & & Pavan (1997) & Sugai et al. (1998) & Roessing (1998) & GEIPOT (1999) \\
\hline \multirow{3}{*}{$1995 / 6$} & $\begin{array}{l}\text { Demanda } \\
\text { Interna }\end{array}$ & 11,0 & 8,9 a 9,0 & 7,0 a 7,1 & 21,3 \\
\hline & Exportação & 20,0 & - & 22,7 a 23,1 & 3,6 \\
\hline & $\begin{array}{c}\text { Demanda } \\
\text { Total }\end{array}$ & 31,0 & 24,9 a 25,0 & 29,7 a 30,2 & 24,9 \\
\hline \multirow{3}{*}{2005} & $\begin{array}{c}\text { Demanda } \\
\text { Interna }\end{array}$ & 13,6 & 10,9 a 12,5 & 8,5 a 8,7 & 26,2 \\
\hline & Exportação & 34,6 & 20,7 & 36,1 a 44,0 & 6,8 \\
\hline & $\begin{array}{c}\text { Demanda } \\
\text { Total }\end{array}$ & 48,2 & 31,6 a 32,3 & 44,8 a 52,5 & 35,0 \\
\hline \multirow{3}{*}{2010} & $\begin{array}{c}\text { Demanda } \\
\text { Interna }\end{array}$ & - & - & 9,5 a 9,8 & 34,0 \\
\hline & Exportação & - & - & 47,3 a 66,2 & 7,4 \\
\hline & $\begin{array}{c}\text { Demanda } \\
\text { Total }\end{array}$ & - & - & 57,1 a 75,7 & 41,4 \\
\hline \multirow{3}{*}{2015} & $\begin{array}{c}\text { Demanda } \\
\text { Interna }\end{array}$ & - & - & - & 43,1 \\
\hline & Exportação & - & - & - & 10,4 \\
\hline & $\begin{array}{c}\text { Demanda } \\
\text { Total }\end{array}$ & - & - & - & 53,5 \\
\hline
\end{tabular}

Fontes: adaptado de Pavan (1997), Roessing (1998), Sugai et al. (1998) e GEIPOT (1999).

Nota-se que os dados de GEIPOT (1999) são os únicos que destoam dos demais, com uma relação invertida entre os níveis de exportações e demanda interna.

Outras duas projeções também foram feitas pelo USDA e ABIOVE, citados por GEIPOT (1999). O USDA prevê que em 2005 a produção brasileira de soja ficará próxima aos 33,3 milhões de toneladas, enquanto a ABIOVE estima em 37,1 milhões de toneladas. GEIPOT (1999) e Pavan (1997) obtiveram em suas projeções 34,2 milhões e 48,2 milhões 
de toneladas, respectivamente, para a produção. Se for assumida uma produtividade média de $2.500 \mathrm{~kg} /$ ha (segundo dados da CONAB, a produtividade média brasileira foi de 2.367 $\mathrm{kg}$ / ha na safra 98/99), estas projeções levam a uma necessidade de área que varia de 13,2 milhões de ha a 19,3 milhões de ha, o que significa a incorporação de 210 mil a 6,31 milhões de ha com relação à safra de 98/99.

Pavan (1997) e GEIPOT (1999) também estimaram os níveis de produção estadual de soja, que estão reproduzidos na Tabela 6.

Tabela 6. Estimativas de produção de soja por estado e participação no total produzido.

\begin{tabular}{|c|c|c|c|c|c|c|c|c|}
\hline \multirow[b]{2}{*}{ Estado } & \multicolumn{2}{|c|}{ Pavan (1997) } & \multicolumn{6}{|c|}{ GEIPOT (1999) } \\
\hline & 2005 & $\%$ & 2005 & $\%$ & 2010 & $\%$ & 2015 & $\%$ \\
\hline Região Norte & 769,8 & $1,6 \%$ & $2.160,3$ & $6,3 \%$ & $2.846,0$ & $7,2 \%$ & $4.030,6$ & $7,6 \%$ \\
\hline RO & 325,7 & $0,7 \%$ & 224,0 & $0,7 \%$ & 246,8 & $0,6 \%$ & 701,1 & $1,3 \%$ \\
\hline AM & & & 2,5 & $0,0 \%$ & 3,0 & $0,0 \%$ & 16,0 & $0,0 \%$ \\
\hline RR & & & 44,5 & $0,1 \%$ & 48,9 & $0,1 \%$ & 79,6 & $0,2 \%$ \\
\hline PA & & & 443,4 & $1,3 \%$ & 532,1 & $1,4 \%$ & 804,6 & $1,5 \%$ \\
\hline TO & 444,1 & $0,9 \%$ & $1.445,9$ & $4,2 \%$ & $2.015,2$ & $5,1 \%$ & $2.429,3$ & $4,6 \%$ \\
\hline Região Nordeste & $3.759,9$ & $7,8 \%$ & $1.691,2$ & $4,9 \%$ & $2.029,3$ & $5,1 \%$ & $3.596,8$ & $6,8 \%$ \\
\hline MA & 651,6 & $1,4 \%$ & 354,7 & $1,0 \%$ & 425,6 & $1,1 \%$ & 553,3 & $1,0 \%$ \\
\hline $\mathrm{Pl}$ & 296,0 & $0,6 \%$ & 47,2 & $0,1 \%$ & 56,6 & $0,1 \%$ & 954,9 & $1,8 \%$ \\
\hline AL & 5,7 & $0,0 \%$ & & & & & & \\
\hline $\mathrm{BA}$ & $2.806,6$ & $5,8 \%$ & $1.289,3$ & $3,8 \%$ & $1.547,1$ & $3,9 \%$ & $2.088,6$ & $4,0 \%$ \\
\hline Região Sudeste & $3.879,4$ & $8,0 \%$ & $3.089,6$ & $9,0 \%$ & $3.423,6$ & $8,4 \%$ & $3.891,1$ & $7,4 \%$ \\
\hline$M G$ & $2.114,6$ & $4,3 \%$ & $1.386,3$ & $4,0 \%$ & $1.549,9$ & $3,7 \%$ & $1.830,0$ & $3,5 \%$ \\
\hline SP & $1.764,8$ & $3,7 \%$ & $1.703,3$ & $5,0 \%$ & $1.873,7$ & $4,7 \%$ & $2.061,1$ & $3,9 \%$ \\
\hline Região Sul & $15.043,2$ & $31,2 \%$ & $14.258,1$ & $41,7 \%$ & $15.273,9$ & $38,9 \%$ & $16.553,3$ & $31,3 \%$ \\
\hline$P R$ & $6.513,1$ & $13,5 \%$ & $7.085,9$ & $20,7 \%$ & $7.631,5$ & $19,4 \%$ & $8.394,7$ & $15,9 \%$ \\
\hline SC & 722,7 & $1,5 \%$ & 745,5 & $2,2 \%$ & 894,4 & $2,3 \%$ & $1.073,2$ & $2,0 \%$ \\
\hline RS & $7.807,4$ & $16,2 \%$ & $6.426,7$ & $18,8 \%$ & $6.748,0$ & $17,2 \%$ & $7.085,4$ & $13,4 \%$ \\
\hline $\begin{array}{l}\text { Região Centro- } \\
\text { Oeste }\end{array}$ & $24.803,5$ & $51,4 \%$ & $13.025,7$ & $38,1 \%$ & $17.277,1$ & $44,0 \%$ & $24.779,6$ & $46,9 \%$ \\
\hline MS & $6.093,1$ & $12,6 \%$ & $2.209,3$ & $6,5 \%$ & $2.319,8$ & $5,9 \%$ & $3.015,7$ & $5,7 \%$ \\
\hline MT & $15.764,2$ & $32,7 \%$ & $7.895,0$ & $23,0 \%$ & $11.597,5$ & $29,5 \%$ & $17.396,3$ & $32,9 \%$ \\
\hline GO & $2.708,6$ & $5,6 \%$ & $2.832,7$ & $8,3 \%$ & $3.257,7$ & $8,3 \%$ & $4.234,9$ & $8,0 \%$ \\
\hline DF & 237,6 & $0,5 \%$ & 88,7 & $0,3 \%$ & 102,1 & $0,3 \%$ & 132,7 & $0,3 \%$ \\
\hline TOTAL & $48.255,8$ & $100,0 \%$ & $34.224,9$ & $100,0 \%$ & $39.300,0$ & $100,0 \%$ & $52.851,4$ & $100,0 \%$ \\
\hline
\end{tabular}

Fonte: adaptado de Pavan (1997) e GEIPOT (1999)

Nota-se que, nos dois trabalhos, a região Centro-Oeste é a principal produtora, com destaque para o estado do Mato Grosso. A região Sul mantém uma posição importante, mas menor que a atual. A grande diferença entre estes dois trabalhos é a região Norte. Para Pavan (1997), esta não será uma região importante para a produção de soja, sendo a produção concentrada em estados onde a soja já é uma realidade (Rondônia e Tocantins). 
GEIPOT (1999), no entanto, atribui à região Norte uma importância superior à região Nordeste e próxima à região Sudeste (chegando a passá-la em 2015), com destaque para o estado do Tocantins.

Mesmo tendo em vista que estas diferenças devem-se às distintas metodologias utilizadas em cada trabalho, e que toda previsão deve ser tomada com ressalvas, estes resultados indicam que, apesar do crescimento do Centro-Oeste ser uma constante, não há consenso quanto à expansão da soja para a região Norte. No entanto, o que se tem observado atualmente é que essa expansão já está ocorrendo, com importantes pólos nos estados do Tocantins, Rondônia, Roraima, Amazonas e Pará.

No Tocantins, as principais regiões são Pedro Afonso e Campos Lindos, onde grandes investimentos estão sendo realizados sob a coordenação da Campo (empresa de promoção agrícola com capital do governo brasileiro e da agência de cooperação internacional japonesa - JICA). Outras regiões deste estado também apresentam potencial (onde alguns testes já estão sendo feitos), entre elas Guaraí e Mateiros.

Rondônia tem suas áreas de expansão para a produção de grãos já delimitada através de seu Zoneamento Econômico-Ecológico. Estas áreas são: o Cone-Sul, região do sul do estado ao sul da BR364, tendo Vilhena como principal cidade; Machadinho D'Oeste e Porto Velho. No entanto, o Cone-Sul deve receber maior destaque, pois as condições de solo e clima são ideais para a produção de grãos.

O Estado de Roraima tem uma condição bastante diferente do restante do país, pois está no hemisfério norte e sua maior parte está comprometida com áreas de proteção, como reservas indígenas e parques nacionais. As áreas destinadas à produção se concentram no nordeste do estado, onde as condições de solo são ruins, necessitando alto grau de tecnologia. Por outro lado, Roraima pretende ter uma ligação viária adequada com o mercado venezuelano, que vem pagando preços bastante altos para os grãos americanos. Além deste mercado, existe a opção do escoamento através dos rios Branco, Negro e Amazonas, chegando ao porto de Itacoatiara, de onde a soja pode ser exportada. 
Já o estado do Amazonas tem sua produção concentrada em dois pólos: campos de Humaitá e Itacoatiara. Em Humaitá a produção tem recebido muitos incentivos do governo do estado. Entretanto, há dúvidas quanto à viabilidade técnica de longo prazo, pois os solos apresentam camada de impedimento físico, sendo inundados nos períodos de chuva. Já em Itacoatiara, a produção está em fase de testes e tem sido estimulada pelo Grupo Maggi.

Por fim, o Estado do Pará apresenta três pólos: Paragominas, Sul do Pará e Santarém. No primeiro pólo, a produção de grãos (milho e arroz, principalmente) vem ocupando o espaço da pecuária, se revelando uma opção econômica para os madeireiros que têm tido dificuldades em obter matéria-prima. A produção de soja deve ser iniciada em breve, com a recomendação das variedades adequadas para a região feitas pela Embrapa.

O Sul do Pará apresenta regiões de cerrado, com a predominância de pastagens. No entanto, existe a dificuldade de se encontrar áreas contíguas abrangentes, devido às limitações de relevo. Outro grande problema dessa região é a falta de cultura agrícola dos produtores - originalmente pecuaristas - que estão iniciando seus plantios.

Por fim, Santarém é uma região que ocupa um lugar de destaque, pois apresenta condições para ser um grande pólo produtor e um grande porto exportador, uma vez que dois projetos de infra-estrutura (BR163 e hidrovia do Tapajós) têm como destino final o porto deste município. Além disso, os grãos de outras regiões, como o oeste do Mato Grosso e Rondônia, também podem utilizar este porto após serem transportados pelo rio Madeira. Como este será um dos portos mais próximos do mercado consumidor, tenderá a ter um dos preços mais altos do país, o que deve estimular a produção local. Por outro lado, este crescimento da agricultura deve gerar um problema social importante, pois a região é predominantemente ocupada por pequenas propriedades. Como a agricultura comercial tende a ser concentradora e deve ser executada por imigrantes do sul, estes pequenos produtores poderão sair em massa de suas terras em direção às zonas urbanas.

Dois estados estão ainda à margem deste processo de expansão da soja: o Acre e o Amapá. Os governadores destes estados assumiram projetos de desenvolvimento que não consideram a agricultura de grande porte como prioridade. Assim, eles não dão incentivos 
para a chegada de agricultores e, como estes agentes são normalmente maximizadores de lucro, acabam buscando outros estados que os beneficie.

No caso do Acre, a soja deve levar mais tempo para ser introduzida pois, além do posicionamento político contrário, as áreas do estado aptas têm uma grande quantidade de castanheiras, árvores preservadas por lei, e que dificultam a mecanização. Por outro lado, o governo do estado está desenvolvendo um programa para intensificação da pecuária e utilizaria a agricultura nas áreas de reforma de pasto. Esta pode ser uma iniciativa interessante, pois o estado é deficiente no abastecimento de grande parte dos gêneros alimentícios e este projeto têm a oportunidade de minimizar este problema sem causar danos ambientais (pois não desmata) nem sociais (pois não desaloja pequenos produtores). Nota-se, assim, que a agricultura no Acre deve-se voltar para o próprio estado.

Já no Amapá a situação é distinta. Este estado tem uma posição geográfica privilegiada, sendo o estado mais próximo dos mercados americano e europeu e, por isto, podendo pagar preços bastante altos para a soja. Além disso, o estado possui grandes áreas de cerrado que poderiam ser utilizadas para a produção de grãos. Com isso, existe grande interesse de empresas em utilizar o Amapá como pólo produtor e porto exportador. Pode ser, inclusive, que o porto de Santana (AP) seja utilizado pelos comboios oriundos da hidrovia do Tapajós, que não teriam necessidade de parar em Santarém (PA). Alguns experimentos estão sendo desenvolvidos pela EMBRAPA e por empresas interessadas no estado e dentro em breve plantios experimentais devem ser iniciados. Portanto, no Amapá, mesmo que o governo não incentive, a produção de soja no estado deve ser viabilizada em poucos anos, sendo economicamente bastante interessante, principalmente pela posição geográfica estratégica do estado.

Para se ter uma melhor visualização da localização das regiões citadas nos parágrafos anteriores, apresenta-se no Apêndice 3 mapas com a localização das regiões citadas anteriormente, bem como da infra-estrutura de transportes destas regiões.

Apesar desta grande movimentação atual, a agricultura na Amazônia não é um evento recente. Desde a década de 60 , os incentivos governamentais para a colonização e o desenvolvimento da infra-estrutura têm estimulado a produção agrícola na região. $O$ tipo de 
agricultura praticado é predominantemente o itinerante (também conhecido como de corte e queima ou agricultura extensiva), que necessita de grandes áreas para que se realize a rotação, implicando produção de pequenas quantidades, normalmente para a subsistência ou destinada ao mercado local.

Segundo Reis \& Magulis (1991), este tipo de agricultura tem sido a principal causa de desmatamento na Amazônia, uma vez que os agricultores vão caminhando sobre a floresta para deslocar suas lavouras. No entanto, este processo produtivo ainda permite o crescimento da floresta secundária nos períodos de pousio, estando bastante relacionado à exploração madeireira, uma vez que o agricultor permite a entrada dos madeireiros em sua área antes de desmatar. A agricultura de corte e queima só é viável em situações de baixa densidade populacional e, com o aumento populacional, há um declínio da produtividade das lavouras, pois o período de pousio para acúmulo de nutrientes é reduzido (Imazon, 1998). Quando isto ocorre, a tendência é que estas áreas agrícolas se convertam em pastagens.

No entanto, Arima \& Uhl (1996) citam a existência de três sistemas pecuaristas no Estado do Pará, com evoluções diferenciadas: i) Campos naturais (Ilha do Marajó); ii) Região de várzea e terra firme do Baixo Amazonas (região de Santarém) e; iii) Região sul do Pará (região da PA-150).

No primeiro caso, a utilização dos pastos é praticamente extrativista, pois sua formação é natural e a pecuária é praticamente a única alternativa produtiva. Já na região do Baixo Amazonas, o processo de ocupação das pastagens é feito em áreas de agricultura de corte e queima (principalmente arroz, mandioca e milho), notadamente ao longo da rodovia Cuiabá-Santarém. Este sistema, que também utiliza pastagens nativas durante parte do ano, mas com a sua inundação durante o período de chuvas, faz com que o gado seja transportado para as pastagens plantadas em terras mais altas (Arima \& Uhl, 1996).

Por fim, no sul do Pará, responsável por 25\% do rebanho do Pará, a pecuária tem um efeito direto no desmatamento. Nesta região os proprietários, normalmente de outros estados, cortaram a floresta para a implantação das pastagens, sem o estágio da agricultura 
itinerante. Observa-se, neste caso, um melhor manejo do rebanho, com maiores investimentos na produção (Arima \& Uhl, 1996).

A intensificação da produção observada no sul do Pará deve-se à presença da infraestrutura de transporte, a qual permite escoar a produção tanto para o mercado de Belém como para o resto do país através da rodovia Belém-Brasília. Nas outras regiões, o acesso principal é apenas através de rios, o que limita o mercado consumidor aos municípios que estejam em seu entorno. Como a estrutura do transporte rodoviário na região Norte é bastante precária, observa-se a predominância do sistema de pastagens implantadas após a agricultura de corte e queima (Imazon, 1998; Reis \& Magulis, 1991).

Com o aumento da população local e o desenvolvimento econômico das regiões de pecuária de fronteira, os preços das terras tornam-se maiores e estimulam a produção de culturas que rendam mais por unidade de área. Com isso, a pecuária passa a dar lugar às culturas comerciais, normalmente para exportação. Arima \& Uhl (1996) observaram nas entrevistas que fizeram com pecuaristas da região sul do Pará que, além das vantagens de clima e sanidade para o rebanho, o que os atraiu à região foi o baixo preço da terra, comparativamente aos estados de São Paulo, Minas Gerais e Goiás (de onde se originaram os pecuaristas), onde há o aumento na área plantada com culturas comerciais (principalmente soja e milho).

Aguiar (1990), citando Zockum $(1978)^{3}$, reforça esta idéia enfatizando que a evolução da soja se deu principalmente em áreas onde anteriormente havia alguma cultura agrícola ou pastagens $(88,4 \%)$, e não matas virgens $(11,6 \%)$. Cita também que nos estados do Paraná e Rio Grande do Sul, a cultura que foi substituída foi o milho, enquanto que em São Paulo foram o algodão e o arroz.

No Centro-Oeste, segundo Olivetti \& Camargo (1992), a conversão foi feita principalmente em áreas de pastagens naturais, com maior intensidade nos períodos de 1968-1978 e 1985-1989. No período 1979-1984, a soja continuou ocupando grande áreas

\footnotetext{
${ }^{3}$ Zockum, M. H. A expansão da soja no Brasil: alguns aspectos da produção e consumo. São Paulo: Fundação Instituto de Pesquisas Econômicas, 1978. vol 1.
} 
de pastagens naturais, mas em um ritmo muito mais lento, e incorporando grandes áreas de outras culturas, que estavam em decadência na região (principalmente o arroz).

Na Tabela 7 pode-se observar quais os produtos que foram substituídos pela soja, considerando todo o território nacional, no período de 1968 a 1989. Esta tabela reforça a argumentação de Zockum (1978) para o Sul e Sudeste (onde o período de expansão da soja foi anterior à década de 70), pois no período inicial as principais culturas substituídas foram milho, café, arroz, feijão e algodão (excetuando, é claro, as pastagens naturais), tendo uma participação relativa maior que nos períodos subsequentes. Para os períodos de expansão da soja para o Centro-Oeste (a partir da década de 70), nota-se um aumento da participação relativa da conversão de soja sobre pastagens naturais, o que denota uma maior incorporação de áreas novas ao processo produtivo.

Tabela 7. Efeito-substituição atribuído à soja no Brasil, 1968-1989, em hectares

\begin{tabular}{lrccc}
\hline $\begin{array}{l}\text { CULTURAS } \\
\text { SUBSTITUÍDAS }\end{array}$ & $1968-1973$ & $1974-1978$ & $1979-1984$ & $1985-1989$ \\
\hline $\begin{array}{l}\text { Pastagem } \\
\text { natural }\end{array}$ & 745.333 & 2.428 .531 & 312.834 & 1.998 .355 \\
\hline Algodão & 177.865 & 34.061 & 20.898 & 287.615 \\
\hline Mamona & 7.951 & 107.503 & 1.521 & 48.905 \\
\hline Mandioca & 140.030 & - & 6.444 & 30.639 \\
\hline Feijão & 209.173 & - & - & 25.259 \\
\hline Amendoim & 55.914 & 51.016 & 3.846 & 21.287 \\
\hline Cacau & 40.618 & 34.103 & - & 1.489 \\
\hline Arroz & 285.231 & - & 17.542 & - \\
\hline Café & 379.905 & 75.885 & 3.546 & - \\
\hline Milho & 586.903 & 16.955 & - & - \\
\hline TOTAL & 2.745 .629 & 2.748 .053 & 367.704 & 2.413 .549 \\
\hline
\end{tabular}

Fonte: Olivetti \& Camargo (1992), com dados básicos do IBGE

Evidencia-se, assim, que, além do impacto direto observado atualmente em algumas poucas regiões, existe um impacto indireto da expansão da agricultura comercial no desmatamento da Amazônia, principalmente da soja para exportação e do milho pois, na medida em que estas culturas avançam, os rebanhos têm que migrar sobre a floresta ou sobre regiões de agricultura de corte e queima, que também acabam se deslocando sobre a floresta. 
Com isso, a avaliação do comportamento da expansão da soja na Amazônia realizada neste trabalho se apoiará no mesmo processo de desenvolvimento observado no Centro-Oeste, uma vez que ele se baseia nos mesmos fatores (terra barata, infra-estrutura de transporte, ocupação de áreas de pastagens). No entanto, é importante destacar que o processo atual tem uma importante diferença em relação à evolução tradicional da fronteira agrícola. Os corredores atualmente em desenvolvimento modificam o sentido do fluxo de exportação e tornam as regiões mais distantes dos centros desenvolvidos do país as mais interessantes em termos logísticos devido às menores distâncias para acessar os mercados internacionais. Isto fará com que o processo de expansão da fronteira agrícola seja mais intenso, pois o avanço tradicional (dos maiores centros para as periferias) se somará ao avanço provocado pelo desenvolvimento desta nova infra-estrutura de transportes, com impactos muito mais marcantes para a economia, meio ambiente e estrutura social da Amazônia.

Na próxima seção, passa-se a analisar mais detalhadamente a estrutura de comercialização atual da soja.

\subsection{Estrutura de comercialização da soja}

Tradicionalmente, a soja produzida no Centro-Oeste era prontamente destinada às outras regiões, sendo transportada até os estados do Sul para o processamento ou exportação através dos portos de Santos e Paranaguá. No entanto, com a evolução da cultura na região, iniciou-se um processo de industrialização, com a implantação de esmagadoras principalmente no sul de Goiás e do Mato Grosso e no Mato Grosso do Sul (vide Tabela 9). Com isso, o destino da produção do Centro-Oeste se tornou bastante diferenciado dependendo da região.

As áreas de fronteira propriamente ditas, como o norte e noroeste do Mato Grosso, o estado de Tocantins, Rondônia, Sudeste do Pará, Sul do Maranhão e Sudoeste do Amazonas, exportam grande parte de sua produção na forma de grão, uma vez que são regiões onde não existem agroindústrias processadoras de soja de grande porte (vide Tabelas 8 e 9). No entanto, em Sorriso (MT), Sinop (MT) e Vilhena (RO) observa-se a presença de pequenas esmagadoras que concorrem com as grandes empresas compradoras 
na obtenção de matéria-prima, mas sem muita significância no mercado. Estas esmagadoras, com capacidade de $300 \mathrm{t} /$ dia ou $600 \mathrm{t} /$ dia, visam o fornecimento de farelo para os seus mercados locais, onde inicia-se o desenvolvimento da produção de carnes, principalmente avicultura e suinocultura.

Já as regiões consolidadas, casos do Sul e Sudeste do Mato Grosso, Sul de Goiás, região de Barreiras (BA) e Mato Grosso do Sul, tendem a exportar tanto a soja em grão quanto os produtos processados (principalmente o farelo) em quantidades semelhantes, uma vez que estão mais próximas às unidades processadoras. No entanto, anteriormente a 1996, a quantidade de farelo exportada era bem maior que a de grãos, mas com a isenção de ICMS (Imposto sobre Circulação de Mercadorias e Serviços) para produtos de exportação, tornou-se mais vantajoso exportar o grão ao invés do farelo, fazendo com que a quantidade de grãos exportados crescesse substancialmente.

Tabela 8. Exportações dos principais produtos do complexo soja por estado brasileiro, em equivalente grão, 1997 e 1998.

\begin{tabular}{|c|c|c|c|c|c|c|}
\hline & \multicolumn{3}{|c|}{1997} & \multicolumn{3}{|c|}{1998} \\
\hline Estado & Grão & Farelo & $\begin{array}{l}\text { Óleo } \\
\text { Bruto' }\end{array}$ & Grão & Farelo & $\begin{array}{c}\text { Óleo } \\
\text { Bruto' }\end{array}$ \\
\hline Tocantins & 9.400 & - & - & 22.683 & - & - \\
\hline Maranhão & 275.787 & - & - & 274.056 & - & - \\
\hline Piauí & 1.000 & - & - & 21.139 & - & - \\
\hline Bahia & 179.555 & 79.929 & - & 435.006 & 121.354 & - \\
\hline Minas Gerais & 193.971 & - & - & 431.817 & - & - \\
\hline Espírito Santo & 38.308 & - & - & 16.509 & - & - \\
\hline São Paulo & 939.190 & - & - & 750.213 & - & - \\
\hline Paraná & 2.799 .905 & 3.371 .881 & 72.117 & 3.510 .234 & 3.435 .562 & 96.378 \\
\hline Santa Catarina & - & 334.055 & 12.087 & - & 429.159 & 14.745 \\
\hline Rio Grande do Sul & 1.003 .240 & 1.641 .500 & 72.661 & 1.231 .050 & 1.659 .369 & 73.114 \\
\hline Mato Grosso & 1.474 .072 & 907.968 & 18.755 & 1.352 .490 & 750.128 & 10.163 \\
\hline Mato Grosso do Sul & 305.518 & 524.839 & 4.816 & 63.752 & 219.376 & 2.944 \\
\hline Goiás & 398.848 & 380.751 & - & 417.715 & 416.333 & 2.986 \\
\hline
\end{tabular}

Fonte: SECEX, adaptação do autor

1 - uma tonelada de soja em grão produz 770 quilos de farelo e 180 quilos de óleo (Sugai et alli, 1998).

Tabela 9. Capacidade instalada de processamento de soja por empresa e estado, 1997

Localização da Unidade

\begin{tabular}{lcc}
\hline Empresa & Município & Estado \\
\hline \hline Ceval & Mimoso & BA \\
\hline Olvebasa (arrend. Santista) & Barreiras & BA
\end{tabular}

Capacidade de Esmagam. Oleaginosas (t./dia)
Processadas

1.800

950


Tabela 9. Capacidade instalada de processamento de soja por empresa e estado, 1997

\begin{tabular}{|c|c|c|c|c|}
\hline \multirow[b]{2}{*}{ Empresa } & \multicolumn{2}{|c|}{ Localização da Unidade } & \multirow{2}{*}{$\begin{array}{c}\text { Capacidade } \\
\text { de Esmagam. } \\
\text { (t./dia) }\end{array}$} & \multirow{2}{*}{$\begin{array}{l}\text { Oleaginosas } \\
\text { Processadas }\end{array}$} \\
\hline & Município & Estado & & \\
\hline Caramuru & Itumbiara & $\mathrm{GO}$ & 1.500 & Soja \\
\hline Caramuru (1995) & São Simão & GO & 1.500 & Soja \\
\hline Comove & Catalão & GO & 1.200 & Soja \\
\hline Ceval & Luziânia & GO & 1.000 & Soja \\
\hline Coinbra & Jataí & GO & 900 & Soja \\
\hline Comigo & Rio Verde & GO & 800 & Soja \\
\hline Granol & Anápolis & GO & 550 & Soja \\
\hline Lasa (1995) & Ipameri & GO & 600 & Soja \\
\hline Maeda & Itumbiara & GO & 350 & Algodão \\
\hline Olvego & Pires do Rio & GO & 600 & Soja \\
\hline Total GO & & & 9.000 & $7,63 \%$ \\
\hline$\overline{A B C}$ & Uberlândia & $M G$ & 1.700 & Soja \\
\hline Cargill & Uberlândia & $M G$ & 2.500 & Soja \\
\hline Rezende & Uberlândia & MG & 1.200 & Soja \\
\hline Total MG & & & 5.400 & $4,58 \%$ \\
\hline Ceval & Campo Grande & MS & 880 & Soja \\
\hline Fatisul & Dourados & MS & 1.500 & Soja \\
\hline Matosul & Três Lagoas & MS & 1.250 & Soja \\
\hline Ovesul (ex-Olvebrás) & Ponta Porã & MS & 200 & Soja (Parada) \\
\hline Pacaembu (arrend. Ovetril) & Fátima do Sul & MS & 650 & Soja (Parada) \\
\hline Sadia & Campo Grande & MS & 1.050 & Soja \\
\hline Soceppar (arrend. Refinadora) & Bataguassú & MS & 1.200 & Soja \\
\hline Total MS & & & 6.730 & $5,70 \%$ \\
\hline Ceval & Cuiabá & MT & 1.600 & Soja \\
\hline Ceval & Rondonópolis & MT & 1.800 & Soja \\
\hline Encomind (1995) & Cuiabá & MT & 900 & Soja \\
\hline Olvepar & Cuiaba & MT & 1.500 & Soja \\
\hline ADM & Rondonópolis & MT & 1.550 & Soja \\
\hline Sperafico (ex-Perdigão) & Cuiabá & MT & 1.200 & Soja \\
\hline Total MT & & & 8.550 & $7,25 \%$ \\
\hline Total PR & & & 35.720 & $30,27 \%$ \\
\hline Total RS & & & 28.950 & $24,53 \%$ \\
\hline Total SC & & & 5.255 & $4,45 \%$ \\
\hline Total SP & & & 13.460 & $11,41 \%$ \\
\hline Total DF, PI, PE e CE & & & 2.060 & $1,75 \%$ \\
\hline TOTAL BRASIL & & & 118.007 & $100,00 \%$ \\
\hline
\end{tabular}

Fonte: ABIOVE

Nota-se que os dados da Tabela 9 não puderam ser atualizados para 1999 uma vez que a Abiove não fornece mais informações relativas às capacidades das plantas 
esmagadoras. De qualquer forma, poucas modificações foram observadas, podendo-se afirmar que a Tabela 9 representa adequadamente o panorama recente da indústria esmagadora nacional.

Destaca-se também que esta indústria passou por períodos em que se sinalizava para a direção dos estados do Centro-Oeste e Nordeste, o que efetivamente não foi observado. A comprovação disto é a comparação entre trabalhos anteriores a 1995 e os dados de capacidade de esmagamento nos anos seguintes.

Para o ano de 1993, Aguiar (1994) argumenta que, apesar dos estados do Rio Grande do Sul, Paraná e São Paulo ainda concentrarem mais de $73 \%$ da capacidade de esmagamento total brasileira (enquanto que Goiás, Mato Grosso e Mato Grosso do Sul correspondiam a $14,49 \%$ ), quando se analisa a desativação e os projetos de novas plantas industriais, nota-se uma tendência de deslocamento das áreas tradicionais para a região Centro-Oeste. Seus dados indicam que nos estados do Rio Grande do Sul (11.730 t/dia desativadas) e São Paulo (5.880 t/dia desativadas) se concentrou 92,7\% da capacidade desativada brasileira naquele ano. Por outro lado, da capacidade total de novas plantas planejadas, $72,4 \%$ se concentravam em Goiás (4.200 t/dia) e 17\% no Maranhão (1.000 t/dia). Além disso, no Mato Grosso e Mato Grosso do Sul foram concluídas naquele ano as obras de plantas que correspondem às capacidades de $5.150 \mathrm{t} / \mathrm{dia}$ e $3.700 \mathrm{t} / \mathrm{dia}$, respectivamente.

Bulhões (1998) também demonstra que, entre 1988 e 1995, a participação dos estados tradicionais (Paraná, Rio Grande do Sul, Santa Catarina e São Paulo) na capacidade de esmagamento de soja brasileira estava se reduzindo enquanto a participação de outros estados (principalmente Mato Grosso, Goiás, Mato Grosso do Sul e Bahia) aumentava.

No entanto, ao se analisar a evolução da capacidade de esmagamento nos anos seguintes (Tabela 10), podemos notar que a expansão está acontecendo em todos os principais estados produtores, e não só no Centro-Oeste, tendo as maiores expansões ocorrido nos estados do Paraná e Minas Gerais. Somente o Rio Grande do Sul e o Distrito Federal reduziram sua capacidade instalada. Nota-se também que os investimentos previstos em 1993 para o estado do Maranhão (citados por Aguiar, 1994) ainda não se 
concretizaram. Estes investimentos referem-se à planta da Ceval em São Luís (MA), que segundo informações da própria empresa, aguardam o aumento da produção do Maranhão, Piauí e Tocantins para iniciar as obras de uma indústria com capacidade para $3.000 \mathrm{t} /$ dia.

Um outro projeto futuro é a implantação de uma unidade esmagadora em Santarém (PA), prevista por pelo menos duas grandes empresas, com capacidade superior a $2.000 \mathrm{t} /$ dia. Esta unidade esmagaria a soja oriunda do norte do Mato Grosso e do oeste do Pará, regiões de influência da BR163 e da hidrovia do Teles Pires-Juruena-Tapajós.

Tabela 10. Capacidade de esmagamento de soja da indústria brasileira por estado, 1995 1999, em toneladas / dia

\begin{tabular}{|c|c|c|c|c|}
\hline ESTADO & 1995 & 1997 & 1999 & $\begin{array}{c}\text { Expansão } \\
(1995-1999)\end{array}$ \\
\hline PARANÁ (PR) & 35.770 & 35.720 & 36.770 & 1.000 \\
\hline RIO GRANDE DO SUL (RS) & 29.000 & 28.950 & 28.930 & -70 \\
\hline SÃO PAULO (SP) & 13.165 & 13.460 & 13.780 & 615 \\
\hline GOIÁS (GO) & 9.000 & 9.000 & 9.660 & 660 \\
\hline MATO GROSSO (MT) & 8.330 & 8.550 & 8.770 & 440 \\
\hline MATO GROSSO DO SUL (MS) & 6.980 & 6.730 & 7.480 & 500 \\
\hline SANTA CATARINA (SC) & 5.075 & 5.255 & 5.210 & 135 \\
\hline MINAS GERAIS (MG) & 4.300 & 5.400 & 5.900 & 1.600 \\
\hline$B A H I A(B A)$ & 2.600 & 2.750 & 2.750 & 150 \\
\hline DISTRITO FEDERAL (DF) & 1.000 & 1.000 & 600 & -400 \\
\hline PERNAMBUCO (PE) & 600 & 600 & 600 & 0 \\
\hline$P I A U I ́(P I)$ & 260 & 260 & 260 & 0 \\
\hline CEARÁ (CE) & 200 & 200 & 200 & 0 \\
\hline TOCANTINS (TO) & - & - & - & 0 \\
\hline MARANHÃO (MA) & - & - & $=$ & 0 \\
\hline RONDÓNIA (RO) & - & - & - & 0 \\
\hline BRASIL TOTAL & 120.277 & 121.872 & 124.907 & 4.630 \\
\hline
\end{tabular}

Fonte: Associação Brasileira das Indústrias de Óleos Vegetais (ABIOVE)

$\mathrm{Na}$ verdade, parte dos grãos utilizados na obtenção deste farelo exportado nas regiões consolidadas vem de grãos das regiões de fronteira. Isto pode ser evidenciado com a análise da Tabela 11, onde pode-se notar que, em 1995, os municípios do Mato Grosso (Sorriso, Barra do Garças, Cuiabá e Rondonópolis) não transportaram sua soja diretamente para os portos, o que evidencia o transporte para alguma indústria ou armazém 
Tabela 11. Principais rotas para a soja em grão, 1995

\begin{tabular}{|c|c|c|c|c|}
\hline $\begin{array}{c}\text { Faixa de } \\
\text { Distância }(\mathrm{km})\end{array}$ & $\begin{array}{c}\text { Distância } \\
(\mathbf{k m})\end{array}$ & Origem & Destino & $\begin{array}{c}\text { Quantidade } \\
\text { Transportada (t) }\end{array}$ \\
\hline $100-149$ & - & - & - & - \\
\hline $150-199$ & - & - & - & - \\
\hline $200-249$ & 232 & Patos de Minas & Uberlândia & $9.682,24$ \\
\hline " & 233 & Três Lagoas & Presidente Prudente & $9.121,64$ \\
\hline $250-299$ & - & - & - & - \\
\hline $300-349$ & 337 & Campo Grande & Três Lagoas & $11.100,53$ \\
\hline $350-399$ & 379 & Londrina & Curitiba & $11.726,27$ \\
\hline$"$ & 391 & Cascavel & Londrina & $8.404,39$ \\
\hline$"$ & 391 & Ribeirão Preto & Santos & $11.520,74$ \\
\hline $400-449$ & 405 & Cascavel & Ponta Grossa & $8.790,84$ \\
\hline " & 418 & Sorriso & Cuiabá & $1.761,83$ \\
\hline $450-499$ & 468 & Rondonópolis & Rio Verde & $12.892,49$ \\
\hline$"$ & 483 & Rondonópolis & Campo Grande & $7.088,19$ \\
\hline$"$ & 489 & Londrina & Paranaguá & $13.075,51$ \\
\hline $450-499$ & - & - & - & - \\
\hline $500-549$ & - & - & - & - \\
\hline $550-599$ & - & - & - & - \\
\hline $600-649$ & 601 & Cascavel & Paranaguá & $7.610,32$ \\
\hline $600-649$ & 610 & Rio Verde & Ribeirão Preto & $8.012,14$ \\
\hline$"$ & 615 & Cuiabá & Campo Grande & $4.515,31$ \\
\hline$"$ & 615 & Campo Grande & Londrina & $12.321,13$ \\
\hline$"$ & 628 & Sorriso & Rondonópolis & $6.440,92$ \\
\hline$"$ & 648 & Barreiras & Brasília & $12.123,97$ \\
\hline $650-699$ & - & - & - & - \\
\hline $700-749$ & - & - & - & - \\
\hline $750-799$ & - & - & - & - \\
\hline $800-849$ & 820 & Rondonópolis & Três Lagoas & $11.313,64$ \\
\hline $850-899$ & 853 & Barra do Garças & Londrina & $10.420,71$ \\
\hline $900-949$ & - & - & - & - \\
\hline $950-999$ & 980 & Cascavel & Santos & $12.515,71$ \\
\hline $1000-1099$ & 1052 & Rondonópolis & Londrina & $10.190,16$ \\
\hline " & 1086 & Campo Grande & Santos & $9.954,45$ \\
\hline$"$ & 1086 & Barreiras & Rio Verde & $11.925,12$ \\
\hline $1100-1199$ & 1139 & Rio Verde & Presidente Prudente & $9.405,87$ \\
\hline " & 1199 & Cuiabá & São José do Rio Preto & $10.880,67$ \\
\hline $1200-1299$ & - & - & - & - \\
\hline $1300-1399$ & 1303 & Cuiabá & Londrina & $3.261,53$ \\
\hline " & 1373 & Rondonópolis & Ponta Grossa & $10.650,84$ \\
\hline $1400-1499$ & - & - & - & - \\
\hline $1500-1599$ & 1523 & Cuiabá & Campinas & $12.709,31$ \\
\hline 11 & 1573 & Cuiabá & Ponta Grossa & $5.657,11$ \\
\hline
\end{tabular}

Fonte: Caixeta Filho et al. (1998), a partir dos dados de GEIPOT (1997)

Dos dados da Tabela 11 pode-se notar ainda a existência de rotas entre municípios de regiões de fronteira e municípios onde existem unidades processadoras ou armazéns da CONAB. Estas rotas são todas no sentido norte-sul, e quase sempre originam-se no Mato Grosso. As regiões com produções de soja ainda mais recentes, como o caso dos estados do 
Tocantins, Maranhão, Piauí e Noroeste Mato-grossense, exportam toda a produção através dos portos do norte do país, principalmente Itaqui e Itacoatiara. Se o destino for Itaqui, existe tanto o transporte totalmente rodoviário, quanto o rodo-ferroviário, através da Ferrovia Carajás. Já se o destino for Itacoatiara, utiliza-se obrigatoriamente a hidrovia do rio Madeira em conjunto com a BR 364 até Porto Velho (SIFRECA, 1999).

A exportação de óleo é feita apenas pelos principais estados produtores, onde estão instaladas as maiores capacidades de esmagamento (Paraná, Rio Grande do Sul, Santa Catarina, Mato Grosso, Mato Grosso do Sul e Goiás). Os outros estados com capacidades menores de processamento da soja colocam o óleo produzido no mercado interno, que é um grande demandante, sendo mais precisamente o terceiro maior consumidor de óleo de soja do mundo, seguido pelos Estados Unidos e pela China (Roessing, 1997).

É interessante notar que esta indústria expande sua capacidade de processamento mesmo trabalhando com capacidade ociosa elevada. Marques \& Sousa (1998) relatam que o Brasil apresenta uma capacidade ociosa na indústria esmagadora de soja de cerca de $35 \%$. Segundo Aguiar (1994), esta ociosidade é proposital pois as indústrias adotam a estratégia de processar toda a soja antes de se iniciar a safra norte-americana, em agosto, aproveitando as cotações mais elevadas que ocorrem no primeiro semestre.

Margarido \& Sousa (1998) confirmam esta hipótese com dados originais da Associação Brasileira das Indústrias de Óleos Vegetais (ABIOVE), onde observou-se que pela média dos últimos 5 anos, $77 \%$ da safra brasileira de soja é comercializada entre março e agosto e $91,5 \%$ da soja em grão, 65,0\% do farelo de soja e 70\% do óleo de soja são exportados entre os meses de abril e setembro. No restante do ano as indústrias esmagam principalmente a soja chamada de "draw-back", que vem a ser soja importada principalmente dos Estados Unidos.

Esta atitude da indústria evidencia um outro fato: o Brasil, mesmo sendo o segundo produtor e exportador mundial, é tomador de preços, ou seja, as cotações dos preços no mercado interno são baseadas nas cotações da Bolsa de Chicago (Margarido \& Sousa, 1998). A formação dos preços no mercado interno acontece em dois níveis: i) preços recebidos pelos exportadores e ii) preços recebidos pelos produtores. 
No primeiro caso, os preços baseiam-se diretamente nas cotações da Bolsa de Chicago, às quais são somados prêmios específicos (Aguiar, 1990). Esses prêmios são determinados de acordo com uma série de critérios, podendo ser positivos ou negativos. Os principais critérios são: i) condições de oferta e demanda no mercado interno; ii) pequenas diferenças de qualidade (principalmente ligadas ao teor de proteína do farelo); iii) eficiência do porto exportador e; iv) condições de pagamento (principalmente para o óleo) (Aguiar, 1990, citando Trigueirinho, 1989). Caffagni (1999) inclui também nesta lista outros fatores, como greves portuárias, chuva, disponibilidade de produto em armazéns portuários, etc.

Já os preços pagos ao produtor são formados a partir de duas formas básicas. Helfand \& Rezende (1998, p. 14) fazem o seguinte relato a este respeito:

"Por ser um produto de exportação, os preços da soja em cada estado devem ser, pelo menos, iguais aos preços FOB nos portos de embarque mais próximos às zonas produtoras de cada estado, menos os custos de transferência de cada região em relação a esses portos de embarque. Os preços da soja podem, contudo, ser maiores que esses "pisos", graças à industrialização do grão e sua venda na forma de óleo e farelo. Tanto o grão como seus subprodutos, o óleo e o farelo, podem também ser comercializados pelos estados entre si, devendo então observar-se a consistência entre os diferenciais de preços e os custos de transferência, de forma análoga ao caso do milho."

Assim, nota-se que a formação do preço para o produtor obedece a duas forças principais: o mercado internacional e a venda para a indústria processadora. Caffagni (1999) apresenta uma planilha para o cálculo da paridade da cotação da bolsa de Chicago (CBOT) para o preço da saca na região produtora (Tabela 12). 
Tabela 12. Procedimento de cálculo para paridade do preço da soja em Chicago para Rondonópolis (MT), maio de 1998.

\begin{tabular}{|c|c|c|}
\hline Procedimento & Fator de conversão & Unidade \\
\hline Cotação CBOT $^{1}$ & 237.83 & US\$ / t \\
\hline Prêmio & -1.84 & US $\$ / t$ \\
\hline Comissão do corretor & 0.5 & $\mathrm{US} \$ / \mathrm{t}$ \\
\hline SUB-TOTAL (1) & 237.28 & US\$ / t \\
\hline Corretagem de câmbio ${ }^{2}$ & 0,445 & $\mathrm{US} \$ / \mathrm{t}$ \\
\hline $\begin{array}{l}\text { Transformação } \\
\mathrm{R} \$ \text { - US\$ }\end{array}$ & 1,1481 & $\mathrm{R} \$ / \mathrm{US} \$$ \\
\hline SUB-TOTAL & 236,82 & $R \$ / t$ \\
\hline Despesas portuárias $^{3}$ & 8,84 & $\mathrm{US} \$ / \mathrm{t}$ \\
\hline Quebra técnica ${ }^{4}$ & 0,59 & $\mathrm{R} \$ / \mathrm{t}$ \\
\hline Frete $^{5}$ & 52,00 & $\mathrm{R} \$ / \mathrm{t}$ \\
\hline SUB-TOTAL & 175.39 & $R \$ / t$ \\
\hline $\begin{array}{l}\text { Transformação para R\$ } \\
/ \mathrm{sc} \text {. }\end{array}$ & 0,06 & $\mathrm{t} / \mathrm{sc}$ \\
\hline Paridade em Rondonópolis & 10,52 & $R \$ / s c$. \\
\hline \multicolumn{3}{|c|}{$\begin{array}{l}\text { Fonte: baseado em Caffagni (1999) } \\
1 \text { - As cotações na bolsa de Chicago são em US } \$ \text { / bushel. A conversão é feita } \\
\quad \text { multiplicando-se esta cotação por } 36,7454 \\
2 \text { - } 0,1875 \% \text { de }(1) \\
3 \text { - Porto de Paranaguá } \\
4 \text { - } 0,25 \% \text { de (1) } \\
5 \text { - obtido no Informe Sifreca, maio de } 1998\end{array}$} \\
\hline
\end{tabular}

Esta paridade não é o preço praticado na região produtora, mas sim um indicativo, uma vez que o preço também está sujeito às variações do mercado interno. No caso estudado anteriormente, a cotação no mercado físico da saca de soja em Rondonópolis era de $\mathrm{R} \$ 11,62$, o que demonstra um efeito positivo do mercado interno nos preços nesta época.

A formação de preços descrita pressupõe um mercado competitivo. No entanto, observa-se que em Rondônia e no Amazonas existe um monopsônio na compra de soja, exercido pelo Grupo Maggi. Este grupo domina a compra nestas regiões pois é o único a operar no corredor BR 364 e rio Madeira, pagando preços que não seguem as regras descritas anteriormente, mas sim políticas da empresa.

Além disso, a influência do mercado interno varia de acordo com a época do ano. $\mathrm{Na}$ safra, os preços da bolsa têm um peso maior e o cálculo da paridade representa melhor os preços nas diversas praças. Na entressafra, no entanto, o mercado externo está fechado para o produto brasileiro devido à entrada do produto americano, e os preços dependem quase que totalmente das variações de oferta e demanda da indústria esmagadora nacional. 
Estas variações, por seu lado, são influenciadas principalmente pelo mercado de farelo, pois este é o principal produto do esmagamento da soja. Como o farelo também é um produto predominantemente voltado para exportação, mesmo o preço da soja para indústria acaba sendo influenciado pelo mercado externo, neste caso o mercado internacional do farelo. No entanto, o efeito é menor, pois o consumo interno de farelo é significativo.

Este comportamento dos preços internos pode ser observado pela pesquisa de Margarido \& Sousa (1998), que identificaram efeitos instantâneos nos preços do mercado interno brasileiro devido às variações na bolsa norte-americana. No entanto, estas variações não são totalmente repassadas pela indústria aos preços pagos ao produtor. Eles observaram que é repassado ao produtor apenas $70,57 \%$ da variação ao preço médio da soja brasileira e apenas $62,22 \%$ para o preço da soja paranaense. Esta pesquisa não identifica o efeito sazonal dos preços, mas apenas uma média anual.

Como causa do não repasse total das cotações de Chicago, os autores citam o consumo de uma parcela da produção no mercado interno e o Custo Brasil (ineficiências infra-estruturais e tributárias), que geram distorções nos valores praticados internamente. Neves (1993) relata também que as variações nos preços recebidos pelos produtores resultam da combinação de três fatores: i) deslocamento da curva de demanda de algum dos produtos derivados (farelo ou óleo de soja); ii) soma dos preços dos diversos serviços adicionados (insumos de comercialização) e; iii) variações na quantidade produzida face às variações climáticas, estrutura de custos, entre outros.

O Custo Brasil vem sendo apontado como uma das principais causas de perda de competitividade da soja brasileira frente à americana. Dentro destas ineficiências, destacase o setor de transportes, que apresenta-se muito mal dimensionado e bastante precário para as necessidades nacionais. Portanto, pode-se afirmar que a infra-estrutura de transportes é um importante fator diferenciador dos preços da soja no mercado interno, como relatado por Helfand \& Rezende (1998), o que vem prejudicando notadamente as regiões de fronteira que possuem estrutura precária. 
Na região Centro-Oeste, segundo dados de 1995 publicados pelo GEIPOT (1998), existia um total de $224.978 \mathrm{~km}$ de estradas, representando uma densidade da malha viária de $1,395 \mathrm{~km} / \mathrm{km}^{2}$, sendo $7,57 \%$ asfaltada e $92,43 \%$ não asfaltada. Além de pequena, esta malha viária também se encontrava em mau estado de conservação, tendo prejudicado o escoamento da safra de 1998/1999. O excesso de buracos na rodovia BR 364, principalmente no trecho próximo a Alto Garças e Alto Araguaia (MT), onerou em cerca de $\mathrm{R} \$ 3,00$ a $\mathrm{R} \$ 4,00$ o frete da tonelada (ou cerca de $\mathrm{R} \$ 0,20 / \mathrm{sc}$ ) transportada neste trecho (Jornal A Gazeta, 1999a). Esta estrada é a segunda em movimento no Estado do Mato Grosso, com um fluxo de 2.000 veículos/dia. Estima-se também que se houver melhorias nesta estrada, além do asfaltamento das rodovias MT 100 e MS 306, esta será a principal rota para a soja até os portos de Santos e Paranaguá, pois diminuiria o trajeto em $250 \mathrm{~km}$, reduzindo o frete em cerca de $\mathrm{R} \$ 11,00$ por tonelada (Jornal A Gazeta, 1999b).

Outra rodovia importante que apresenta sérios problemas é a MT 170, na região da Chapada dos Parecis (MT). Esta região é responsável por 4\% da produção nacional de soja e esteve praticamente isolada no início de 1999 devido à deterioração da rodovia por conta das chuvas. Estima-se, para este caso, que o valor do frete tenha aumentado em US\$1.00/ tonelada (Jornal A Gazeta, 1999d).

A malha viária da região Norte também é extremamente precária. O GEIPOT (1998) indica a existência de apenas $96.401 \mathrm{~km}$ de rodovias, com uma densidade baixíssima de $0,025 \mathrm{~km} / \mathrm{km}^{2}$, sendo que somente $8,7 \%$ desta malha é pavimentada. Do total de rodovias pavimentadas, cerca de $44 \%$ correspondem a rodovias estaduais, enquanto cerca de $43 \%$ por rodovias federais e $13 \%$ por rodovias municipais, demonstrando que a malha viária é composta, principalmente, por grandes eixos (como a Belém-Brasília e a Cuiabá-Porto Velho).

No entanto, os investimentos governamentais e privados realizados no desenvolvimento de novas alternativas para o escoamento da soja devem alterar significativamente o panorama produtivo brasileiro, pois viabilizam áreas pouco exploradas, principalmente localizadas na Amazônia. Neste sentido, Cunha (1994, p. 48) relata que: 
"É muito forte a correlação entre o crescimento da malha viária e a expansão da agricultura nos cerrados. Ainda hoje (1994) é precária a rede de transportes da região mas, em algumas áreas ela apresentou melhorias consideráveis. Foi justamente nessas áreas que a agricultura tendeu a florescer."

Assim, o estudo dos novos investimentos em infra-estrutura de transporte se faz necessário para a elaboração de cenários futuros para a soja no Norte do país. Na seção seguinte, serão analisados os novos caminhos para a exportação que estão em desenvolvimento.

\subsection{Estruturas de transporte atual e em desenvolvimento no Norte, Centro- Oeste e Nordeste do país}

Com a chegada da soja a regiões cada vez mais longínquas dos centros consumidores e dos portos exportadores do Sul e Sudeste, começou a se viabilizar o desenvolvimento dos corredores em direção ao Norte do país. Estes corredores não são novos e já vêm sendo utilizados há bastante tempo para o comércio regional dos estados do Norte. Entretanto, só recentemente passaram a receber maior atenção devido, principalmente, aos investimentos privados realizados. O exemplo mais representativo é a hidrovia do rio Madeira, que exporta a soja em grão da região da Chapada dos Parecis (noroeste de Mato Grosso) e de Rondônia (região de Vilhena) através do porto de Itacoatiara (AM).

O que se vem observando então é que em regiões onde a infra-estrutura de transporte permite a exportação de grãos pelo Norte, isto tem sido efetivamente realizado (caso da ferrovia Carajás e da hidrovia do rio Madeira). Caso contrário, a produção segue seu fluxo tradicional até os portos do sul e sudeste ou então até as agroindústrias mais próximas. Na safra de 1998, segundo dados de Caffagni (1999), foram escoados por estes dois corredores 860 mil toneladas, sendo 370 mil pelo rio Madeira e 490 mil pelo porto de Itaqui (MA) (neste caso a utilização da ferrovia Carajás não é obrigatória, existindo um fluxo rodoviário entre a região produtora - Balsas - e o porto de Itaqui, segundo dados do SIFRECA). 
Obviamente, a mudança no sentido do escoamento da soja decorre de uma redução nos custos de transportes causada por dois fatores básicos: i) a utilização da multimodalidade e ii) a redução da distância até o porto estrangeiro.

A multimodalidade permite que se minimizem os custos unitários de transporte pois utiliza a combinação entre os diversos modais como alternativa ao transporte exclusivamente rodoviário que predomina no país. Este tem sido considerado, juntamente com os altos custos portuários e tributários, como um importante fator que transforma a soja brasileira menos competitiva que a americana, mesmo tendo um custo de produção menor. Nos Estados Unidos, a utilização de hidrovias e ferrovias é muito mais disseminada.

A redução da distância até o porto de destino final ocorre nestes novos canais de escoamento da soja pois a agricultura está se desenvolvendo em direção às regiões mais setentrionais, que se localizam mais próximos dos principais mercados consumidores, principalmente a Europa. Assim, tradicionalmente, a soja tem que se direcionar para os estados do Sul e do Sudeste, pois é onde se localizam as plantas esmagadoras, os portos exportadores e grande parte da infra-estrutura de armazenagem e comercialização de grãos. No entanto, esta soja acaba retornando para o norte no momento de ser exportada para a Europa ou a Ásia. Com os investimentos em portos (exemplo de Itacoatiara, AM, e Itaqui, MA) e em vias de escoamento na região Norte do país, permite-se que a soja faça apenas a rota sul-norte, reduzindo o trajeto total.

Lício \& Corbucci (1996) descrevem com mais detalhes alguns destes corredores planejados que direcionam a produção para o Norte. Neste caso eles relatam apenas os que contam com investimentos governamentais, sendo eles: i) o Corredor Noroeste; ii) o Corredor Centro-Norte; iii) o Corredor Nordeste e iv) o Corredor Centro-Leste.

O primeiro corredor corresponde à BR 163/364 (que liga Cuiabá a Porto Velho), o rio Madeira e o rio Amazonas. Esta é a hidrovia do rio Madeira e vem sendo utilizada tradicionalmente pela população da região. O destino é o porto de Itacoatiara, onde existe um terminal graneleiro privado que carrega os navios com destino ao mercado europeu. Sua área de abrangência inclui, com exceção da Chapada dos Parecis, as regiões de fronteira agrícola onde ainda estuda-se a introdução de culturas comerciais, principalmente a soja. 
Segundo cálculos de Lício e Corbucci (1996), o escoamento por esta via economizaria, no longo prazo, US\$ $44.50 / \mathrm{t}$, sendo atualmente esta economia da ordem de US\$23.50/t.

O Corredor Centro-Norte é composto por dois eixos: i) rio Tocantins - ferrovia Norte-Sul - ferrovia Carajás e ii) rio Araguaia (até Xambioá ou Conceição do Araguaia) rodovia (Xambioá - Estreito ou Conceição do Araguaia - Estreito) - ferrovia Norte-Sul ferrovia Carajás. Este corredor opera atualmente apenas a sua parte ferroviária, sendo que o transporte pelo do rio Araguaia está prestes a entrar em operação. Testes de transporte no rio Araguaia foram feitos já na safra 1998/1999, com um carregamento de 600 toneladas de calcário até o município de São Félix do Araguaia (MT), com o retorno de soja oriunda do município de Água Boa (MT) até o porto de Itaqui (MA), que é o destino final deste corredor (Jornal A Gazeta, 1999c). Com a redução dos custos de transporte para exportação, esta hidrovia também pode minimizar o problema de abastecimento de grãos do Nordeste, sendo esta possibilidade já considerada pelos produtores da região do leste do Mato Grosso (Jornal A Gazeta, 1999c) e planejada pela Companhia Vale do Rio Doce para 2000 (Pinto, 1999). No entanto, este corredor vem enfrentando problemas para a sua total efetivação, uma vez que os rios passam por trechos de acesso restrito, como reservas indígenas. Nas condições atuais, este corredor apresenta uma redução dos custos da ordem de US\$16.00/t, enquanto que, se forem realizadas todas as obras necessárias (num total de investimentos da ordem de US\$ 222,6 milhões, referentes às obras de melhorias na hidrovia, asfaltamento da BR 153 entre Marabá e São Geraldo e conclusão do trecho ferroviário entre Imperatriz e Estreito), a redução dos custos ficará em US\$ 47.00 / t (Lício \& Corbucci, 1996).

Este corredor tende a ser um dos mais importantes em termos de desenvolvimento da produção agrícola do país. Braga et al. (1997) estimaram que a área de influência deste corredor, apta à produção de grãos e sem impedimentos legais (como reservas indígenas, parques nacionais e áreas de reserva legal), é de aproximadamente 30 milhões de hectares, abrangendo os estados de Goiás (noroeste), Mato Grosso (leste), Piauí (sul), Maranhão (sul) e todo o estado de Tocantins. Se pensarmos que a utilização do cerrado era de 45 milhões 
de hectares em 1995 (Braga et al., 1997, citando Macedo, 1995 ${ }^{4}$ ), nota-se que o impacto deste corredor na geografia de produção brasileira é bastante significativa.

O Corredor Nordeste tem importância maior para o mercado interno, principalmente para o abastecimento de grãos da região Nordeste. Ele é constituído principalmente pelo rio São Francisco e pela malha viária do Nordeste. Este corredor é importante para impedir que seja mais barato para o Nordeste comprar grãos da Argentina que das regiões produtoras brasileiras. Assim, o oeste baiano e as regiões produtoras mineiras podem fornecer para a região seus produtos agrícolas.

Por fim, o Corredor Centro-Leste tem importância maior para o Estado de Minas Gerais, pois tem como tronco principal a ferrovia Vitória-Minas. Sua área de abrangência vai desde o Distrito Federal ao Noroeste de Minas Gerais (até Pirapora) e a região de Belo Horizonte.

Um corredor também bastante discutido é o que envolve a hidrovia dos rios Juruena, Teles Pires e Tapajós. Este corredor abrange a rodovia BR 163, do norte do Estado do Mato Grosso até Itaituba (PA), e o rio Tapajós até Santarém (PA), podendo também fazer este trajeto inteiramente por rodovia até Santarém (PA). Existem projetos também de utilização dos rios Teles Pires e Juruena, expandindo a hidrovia até o Estado do Mato Grosso. Como estes rios também passam por áreas de acesso restrito, devem enfrentar os mesmos problemas que a hidrovia do Araguaia - Tocantins vem enfrentando atualmente.

Quanto ao asfaltamento da BR163, este processo deve ser mais rápido, pois existe um movimento muito forte a seu favor e poucas ações restritivas. Já em 1999, um grupo de empresários e políticos da região norte do Estado do Mato Grosso fez o transporte de um carregamento de mais de 100 caminhões com soja através deste corredor. Em Itaituba (PA), esta soja encontrou balsas que operam na hidrovia do rio Madeira, e foi transportada até Santarém. A estimativa dos participantes deste movimento é que este trajeto economizou cerca de $\mathrm{R} \$ 2,00$ / sc, mesmo com as condições precárias em que partes da rodovia BR 163

\footnotetext{
${ }^{4}$ Macedo, J. Prospectives for the rational use of the Brazilian Cerrados for food production. Planaltina. EMBRAPA - CPAC, 1995. $19 \mathrm{p}$.
} 
se encontram e com a necessidade de grandes investimentos no porto de Santarém (Jornal A Gazeta, 1999e).

Um outro corredor de exportação do Centro-Oeste, discutido por Marques \& Caixeta Filho (1998), é a Ferronorte. Neste caso, o sentido de escoamento é o mesmo que o atual (Centro-Oeste - Sudeste), mas o transporte do Centro-Oeste até o porto de Santos é feito apenas pelo modal ferroviário, sem necessidade de transbordos. Esta ferrovia iniciou suas obras efetivamente em 1992, mas foram interrompidas inúmeras vezes devido à necessidade de pagamento de dívidas. Somente em 1998 a construção da ferrovia foi retomada à plena força, chegando até o município de Alto Taquari (MT), coincidindo com a conclusão da ponte rodo-ferroviária sobre o rio Paraná (que liga a Ferronorte à malha ferroviária do Estado de São Paulo). O projeto é levar a ferrovia até Cuiabá e, posteriormente, até Porto Velho, Uberlândia e Santarém. A previsão é que até 2001 a ferrovia já esteja operando a partir de Rondonópolis (MT). Marques \& Caixeta Filho (1998), citando dados do projeto da Ferronorte, relatam que a economia prevista no frete de Inocência a Santos (trecho já concluído) é de até $R \$ 20,00$ / t. Em Rondonópolis chegaria a $\mathrm{R} \$ 27,00 / \mathrm{t}$ e em Cuiabá, $\mathrm{R} \$ 32,00 / \mathrm{t}$.

Estes projetos de infra-estrutura estão sendo considerados como prioritários pelo governo federal (vide Tabela 13) e estão incluídos no Programa "Brasil em Ação" (Ministério dos Transportes, 1999), mais recentemente renomeado para "Avança Brasil" (Ministério do Planejamento, 1999), para caracterizar o Plano Plurianual (PPA) de investimentos do governo federal. Além dos projetos citados anteriormente, também estão neste programa: i) o asfaltamento da BR 317 , no Acre; ii) as melhorias na BR 364/163, no Mato Grosso, Goiás e Mato Grosso do Sul; iii) o asfaltamento da BR 230 (Transamazônica) entre Altamira (PA) e Marabá (PA); iv) o asfaltamento da BR 156, no Amapá; v) o asfaltamento da BR 174 no Amazonas e Roraima e outros projetos no Nordeste, Sudeste e Sul do país. 
Tabela 13. Investimentos planejados ou em andamento do Programa "Brasil em Ação", em milhões de reais

\begin{tabular}{lccccc}
\hline Corredor & Rodoviário & Ferroviário & Hidroviário & Portuário & TOTAL \\
\hline $\begin{array}{l}\text { Extremo Oeste } \\
\text { (hidrovia do }\end{array}$ & 60,2 & - & 24,0 & - & 84,2 \\
Madeira) & & & & & \\
\hline Norte (BR 174) & 168,0 & - & - & - & 168,0 \\
\hline $\begin{array}{l}\text { Oeste-Norte } \\
\text { (hidrovia Teles }\end{array}$ & - & - & - & - & - \\
Pires - Tapajós) & & & & & \\
\hline $\begin{array}{l}\text { Centro-Norte } \\
\text { (hidrovia }\end{array}$ & - & - & 222,4 & \\
$\begin{array}{l}\text { Araguaia - } \\
\text { Tocantins) }\end{array}$ & & & & & \\
\hline $\begin{array}{l}\text { Nordeste } \\
\text { (hidrovia do São }\end{array}$ & - & & & & \\
Franscisco) & & & & & \\
\hline
\end{tabular}

\begin{tabular}{|c|c|c|c|c|c|}
\hline $\begin{array}{l}\text { Centro-Leste } \\
\text { (Rede de } \\
\text { transportes do } \\
\text { MT, GO, DF e } \\
\text { MG) }\end{array}$ & $1.083,8$ & $1.575,7$ & - & - & $2.659,5$ \\
\hline $\begin{array}{l}\text { Sudeste (Rede } \\
\text { de transportes de } \\
\text { SP e RJ) }\end{array}$ & & - & 60,0 & $2.309,4$ & $2.369,4$ \\
\hline $\begin{array}{l}\text { Rodovia do } \\
\text { Mercosul }\end{array}$ & $1.498,0$ & - & - & - & $1.498,0$ \\
\hline Subtotal & $2.810,0$ & $1.575,7$ & 317,4 & $2.701,4$ & $7.404,5$ \\
\hline $\begin{array}{l}\text { Recuperação } \\
\text { descentralizada } \\
\text { de rodovias }\end{array}$ & 720,0 & - & - & - & 720,0 \\
\hline Total Geral & $3.530,0$ & $1.575,7$ & 317,4 & $2.701,4$ & $8.124,5$ \\
\hline
\end{tabular}

Nota-se que os recursos estão sendo destinados principalmente às regiões com melhor infra-estrutura e principalmente para o modal rodoviário e o sistema portuário. Os investimentos em ferrovias também são significativos, mas totalmente localizados em um corredor, o Centro-Leste, que tem como porto de destino o de Tubarão (ES). A maior parte dos recursos destinados a hidrovias está sendo direcionado à hidrovia Araguaia-Tocantins. Já os investimentos no sistema portuário estão sendo planejados principalmente para Santos (SP) e Sepetiba (RJ), seguido pelos portos do Nordeste. 
No entanto, mesmo com menos recursos que as outras regiões, os projetos planejados para as regiões Centro-Oeste e Norte têm uma grande importância para o desenvolvimento regional.

A BR 317 é uma rodovia importante para a ligação da Amazônia brasileira com a boliviana. O projeto prevê a construção de $200 \mathrm{~km}$ e a melhoria de mais $140 \mathrm{~km}$, permitindo a ligação terrestre entre Rio Branco e Assis Brasil, na divisa com a Bolívia e o Peru. Esta ligação faz parte dos planos brasileiros de acesso ao Oceano Pacífico e beneficiará os estados de Rondônia, Amazonas, Mato Grosso e Acre. Os investimentos totais são da ordem de $\mathrm{R} \$ 80$ milhões e a conclusão da obra está prevista para o final de 1999.

Já as rodovias BR 364 e BR 163 são dois importantes eixos para o escoamento da soja do Centro-Oeste, pois abrangem desde Porto Velho (RO) até Frutal (MG) e desde Santarém (PA) até Dourados (MS). São também a principal rota de escoamento do estado do Mato Grosso, escoando tanto a soja do norte do Estado como a do sul. As obras de melhoria e ampliação estão sendo efetuadas em apenas alguns trechos selecionados: a) Frutal (MG) a Santa Vitória (MG), trecho que deve ser construído e pavimentado; b) Alto Araguaia (MT) a Cuiabá (MT), onde deve ser melhorado, sendo este um trecho problemático na safra 1999/2000; c) Rondonópolis (MT) a Nova Alvorada do Sul (MS), sendo este, atualmente, o principal caminho para o transporte da soja do Mato Grosso e Mato Grosso do Sul para os portos de Santos e Paranaguá. Estas obras de melhoria visam uma solução provisória para o transporte de soja para exportação, pois os outros investimentos ligados às hidrovias e ferrovias devem reduzir o fluxo de longas distâncias por estas vias.

O asfaltamento de parte da Transamazônica (BR 230) entre os municípios de Marabá (PA) e Altamira (PA) tem um importante papel no desenvolvimento da região Amazônica, pois permitirá um fluxo maior nas regiões que começaram a ser colonizadas na década de 70. Seguindo a lógica da colonização da região, este asfaltamento deve impulsionar a economia ao longo dos $450 \mathrm{~km}$ a serem pavimentados, principalmente na direção da pecuária e da agricultura comercial, devido à facilidade de acesso ao Centro-Sul (através da PA 150, que passa por Marabá, e da Belém-Brasília) e a corredores de 
exportação (uma vez que por Marabá também passam a ferrovia Carajás, que leva até o porto de Itaqui, MA, e o rio Tocantins, que no futuro poderá ser navegável até Belém). Os investimentos neste caso são da ordem de R\$150 milhões para os anos de 1999 e 2000. Além disso, o asfaltamento da BR 230 no seu trecho entre Marabá e São Geraldo do Araguaia (PA), na beira do rio Araguaia, já está em andamento e permitirá a ligação da ferrovia Carajás com a hidrovia do Araguaia.

Um outro projeto relacionado ao desenvolvimento de corredores de transporte no país é o asfaltamento da ligação entre Brasil e a Guiana Francesa através da BR 156. Esta rodovia permitirá um maior intercâmbio comercial entre estes dois países e pretende dinamizar a economia do estado do Amapá.

Para o extremo norte do país, outro projeto importante é o asfaltamento da BR 174, que liga Manaus a Boa Vista e Boa Vista à divisa com Venezuela. Este projeto já está em fase adiantada de desenvolvimento ( $94 \%$ dos $910 \mathrm{~km}$ já estão pavimentados) e irá fazer com que o Brasil tenha uma saída para o Caribe, através do porto de Puerto Ordáz, no rio Orinoco. Além disso, também permite o acesso ao mercado venezuelano, que não produz grãos e vem pagando preços bastante altos pelos produtos agrícolas americanos.

Além destes projetos, que contam com financiamentos do governo federal, outros dois caminhos deverão ter importância num futuro próximo: i) as hidrovias do rio Capim e Marajó, no Pará, ii) a BR 242 no Mato Grosso e iii) a BR 401 em Roraima.

O rio Capim já vem sendo navegado há algum tempo para o transporte de caulim da região sudeste do Pará. No entanto, a região de Paragominas vem observando um crescimento vertiginoso na produção de grãos e já considera o uso deste rio para $o$ transporte de seus grãos tanto para a exportação através do porto de Vila do Conde, quanto para o acesso ao mercado de Belém (que importa de outros estados $90 \%$ de seu milho). A hidrovia do Marajó tornaria mais curta a ligação entre Belém e Macapá, na medida em que ligaria dois rios que passam pela ilha do Marajó.

Já a BR 242 será a ligação do norte do Mato Grosso com Primavera do Leste e Canarana/Água Boa. Com isto, o acesso às indústrias da região de Rondonópolis e à 
hidrovia do Araguaia será viável para a soja produzida em Sorriso, Sinop, Nova Mutum e Lucas do Rio Verde. Esta rodovia viabiliza uma região com grande potencial para a produção agrícola e que atualmente encontra-se isolada por falta de infra-estrutura de transportes adequada. Além disso, aparentemente esta opção é melhor que a BR 163 (Cuiabá - Santarém) para a exportação de soja do norte do Mato Grosso, pois o trajeto de Sorriso ao porto no rio das Mortes (início da hidrovia do Araguaia) tem um trecho rodoviário $900 \mathrm{~km}$ menor (600 km contra $1.500 \mathrm{~km}$ até Santarém). O problema desta opção é um alto número de transbordos ( 4 contra 1 , no caso de apenas rodovia, ou 2 , no caso de rodovia-hidrovia), o que aumenta a quantidade de quebras de grãos. Por outro lado, com a viabilização da hidrovia Teles Pires - Juruena - Tapajós, o transporte até Santarém será imbatível em termos de custos e esta opção deverá ser abandonada para a exportação de soja do norte do Mato Grosso.

A BR 401 é a interligação entre Boa Vista e a Guiana e está sendo asfaltada do lado brasileiro até a divisa com este país. Esta rodovia faria a ligação de Roraima com o Caribe através do porto de Georgetown, com trajeto de cerca de $500 \mathrm{~km}, 300 \mathrm{~km}$ a menos que a opção pela Venezuela. Além disso, em conjunto com a BR 156 no Amapá, esta rodovia criará uma ligação entre Boa Vista e Macapá, passando pelas Guianas e Suriname, sendo este corredor chamado de Arco Norte.

Destaque-se ainda que o Plano Plurianual 2000 - 2003 ("Avança Brasil") contém, além dos projetos anteriormente citados, uma lista bastante vasta de oportunidades de investimento em transportes, que necessita de contrapartidas do setor privado e de capital estrangeiro para sua total viabilização (a lista referente aos projetos que influenciarão a produção de grãos na Amazônia é apresentada no Apêndice 1). No entanto, a determinação de prioridades para os investimentos públicos ainda necessita de aprovação do Congresso Nacional, sendo que os recursos ainda não foram alocados para os projetos. Para o ano 2000 apenas 5 projetos de desenvolvimento de infra-estrutura de transportes no Norte, Nordeste e Centro-Oeste deverão receber recursos governamentais (Ministério do Planejamento, 1999), sendo eles, basicamente, continuidade dos projetos do "Brasil em Ação". Estes projetos estão apresentados na Tabela 14 
Tabela 14. Investimentos previstos para 2000 para projetos de melhoria de infra-estrutura de transportes pelo Plano Plurianual $2000-2003$

\begin{tabular}{|c|c|c|}
\hline Via & Importância & $\begin{array}{l}\text { Recursos previstos para } \\
2000 \\
\end{array}$ \\
\hline BR 174 & $\begin{array}{l}\text { Ligação entre Manaus, Boa } \\
\text { Vista e a Venezuela }\end{array}$ & $\mathrm{R} \$ 11,6$ milhões \\
\hline $\begin{array}{l}\text { Ferrovia Norte-Sul (trecho } \\
\text { Imperatriz - Estreito) }\end{array}$ & $\begin{array}{c}\text { Ligação da Ferrovia Norte- } \\
\text { Sul com a hidrovia do } \\
\text { Tocantins }\end{array}$ & $\mathrm{R} \$ 49,0$ milhões \\
\hline Eclusa de Tucuruí & $\begin{array}{l}\text { Permitir navegação de } \\
\text { Marabá até Belém }\end{array}$ & $\mathrm{R} \$ 30,0$ milhões \\
\hline Hidrovia Araguaia-Tocantins & $\begin{array}{l}\text { Escoar grãos do Tocantins, } \\
\text { Mato Grosso e Goiás para o } \\
\text { porto de Itaqui }\end{array}$ & $\mathrm{R} \$ 10,0$ milhões \\
\hline $\begin{array}{c}\text { Hidrovias do Capim e } \\
\text { Marajó }\end{array}$ & $\begin{array}{c}\text { Escoar grãos e caulim até o } \\
\text { porto de Vila do Conde e } \\
\text { melhorar o acesso fluvial à } \\
\text { Macapá }\end{array}$ & $\mathrm{R} \$ 8,5$ milhões \\
\hline
\end{tabular}

Além dos grandes eixos, a infra-estrutura de transportes também necessita das ligações regionais, que permitem o acesso dos produtores e comunidades a estas vias ou a centros urbanos. Na Amazônia, as condições destas vias secundárias são extremamente precárias, sendo o principal limitante para a decisão do agricultor sobre qual cultura plantar. Guimarães \& Uhl (1998) mostram que, na região de Paragominas (PA), as estradas de terra municipais são muito precárias, ficando alguns meses do ano intransitáveis.

É interessante notar que esta colonização em áreas de difícil acesso vem sendo estimulada pelo desenvolvimento da atividade madeireira (Veríssimo et. al., 1995). Estas áreas são inicialmente exploradas pelos próprios colonos, que cortam a madeira de suas áreas e as vendem aos caminhoneiros autônomos, interessados em fornecer matéria-prima para as diversas serrarias da região (Paragominas, no Pará, é a cidade com a maior concentração de serrarias do Brasil). Além disso, se alguma região se mostra de especial interesse aos madeireiros ou aos grandes produtores, eles próprios bancam a construção de estradas para acessar regiões mais longínquas (Guimarães \& Uhl, 1998, p. 2).

Com estradas precárias, o transporte através de caminhões fica restrito e bastante oneroso, reduzindo o fluxo de mercadorias dentro da própria região (Guimarães \& Uhl, 1998). Estes autores também levantaram os custos de transporte (vide Tabela 5) nestas 
regiões e os compararam com os da região Bragantina, que apresenta a melhor infraestrutura no Estado do Pará.

Tabela 15. Custos para transportar produtos agrícolas por caminhão (US $\$ / \mathrm{km}$ ) sobre diferentes tipos de estradas na Amazônia Oriental, 1998

\begin{tabular}{|c|c|c|c|c|}
\hline & \multicolumn{3}{|c|}{ Paragominas } & \multirow{2}{*}{$\begin{array}{c}\text { Zona } \\
\text { Bragantina }\end{array}$} \\
\hline & $\begin{array}{c}\text { Estrada de chão } \\
\text { em condições } \\
\text { precárias }\end{array}$ & $\begin{array}{l}\text { Estrada de chão } \\
\text { em boas condições }\end{array}$ & $\begin{array}{l}\text { Asfalto (distâncias } \\
\text { menores que } 100 \\
\text { km) }\end{array}$ & \\
\hline Frete (US\$/km) & 5,94 & 3,97 & 3,63 & 1,24 \\
\hline Desvio padrão & 1,98 & 1,02 & 1,53 & 0,48 \\
\hline $\begin{array}{l}\text { Custo de } \\
\text { oportunidade do } \\
\text { produtor (US\$/km) }\end{array}$ & 0,08 & 0,06 & 0,05 & 0,06 \\
\hline Total (US\$/km) & 6,02 & 4,03 & 3,68 & 1,30 \\
\hline Total (US\$/t:km) & 0,56 & 0,27 & 0,25 & 0,16 \\
\hline
\end{tabular}

Fonte: Guimarães \& Uhl (1998)

Ao se comparar estes valores com os momentos de transporte levantados pelo SIFRECA no mês de julho de 1998 (Tabela 16), nota-se que os momentos de transporte na Amazônia são extremamente altos, mesmo considerando as regiões mais desenvolvidas e as estradas asfaltadas. Isto pode ser parcialmente explicado pelo pequeno fluxo de mercadorias desta região, uma vez que as produções regionais são baixas e incertas (Guimarães \& Uhl, 1998). 
Tabela 16. Momentos de transporte mínimo, médio e máximo no Brasil para alguns produtos selecionados, em $\mathrm{R} \$ / \mathrm{t} \cdot \mathrm{km}$, julho de 1998

\begin{tabular}{lccc}
\hline & Mínimo & Médio & Máximo \\
\hline $\begin{array}{l}\text { Carne bovina } \\
\text { (caminhão) }\end{array}$ & 0,0672 & 0,0765 & 0,0903 \\
\hline Soja & 0,0148 & 0,0414 & 0,1350 \\
\hline Milho & 0,0303 & 0,0494 & 0,1158 \\
\hline Feijão & 0,0386 & 0,0409 & 0,0438 \\
\hline $\begin{array}{l}\text { Adubos e } \\
\text { fertilizantes }\end{array}$ & 0,0352 & 0,0385 & 0,0438 \\
\hline
\end{tabular}

Fonte: SIFRECA

Assim, nota-se que o desenvolvimento da Amazônia está bastante condicionado à melhoria da infra-estrutura de transportes, pois como citam Guimarães \& Uhl (1998), as comunidades de Paragominas que estão mais distantes da cidade têm que produzir culturas principalmente para subsistência ou de baixo valor agregado, pois dependem das condições precárias de transporte para ter acesso ao mercado. Em contrapartida, comunidades mais próximas à zona urbana produzem culturas com maior valor agregado e têm uma relação mais intensa com o mercado. 


\section{MATERIAL E MÉTODOS}

A atividade de planejamento é extremamente necessária para o desenvolvimento ordenado de uma região ou de uma atividade produtiva. Assim, muitos trabalhos são realizados no sentido de criar uma base de dados que subsidie a tomada de decisão de agentes governamentais (em projetos de desenvolvimento ou de investimento em infraestrutura) ou de empresários (no planejamento de suas atividades produtivas). Alguns destes trabalhos têm como objeto de análise tanto a região amazônica como as culturas agrícolas e objetivam, principalmente, contribuir para a elaboração de políticas públicas de desenvolvimento.

O presente trabalho também tem a pretensão de contribuir para a formulação de políticas públicas para o setor agrícola na Amazônia e, para isto, utilizará um referencial analítico bastante semelhante ao que Stone (1998) utilizou para o setor madeireiro. Este trabalho, por sua vez, se baseia no modelo original da teoria de uso da terra de von Thünen de 1826 (citado por Barlowe, 1965), que pressupunha um único mercado consumidor central, sendo as atividades desenvolvidas nas terras do entorno determinadas pelo preço do produto no mercado central e pelo custo de transporte.

\subsection{Formalização da teoria de uso da terra de von Thünen}

Ferreira (1989) apresenta a formalização do modelo de von Thünen baseado em Dunn (1970). Este autor relata que o elemento central na determinação da distribuição espacial das atividades agrícolas é a concorrência pelo uso da terra, que se concretiza com os pagamentos para a sua utilização. Ganha a concorrência quem der o lance mais alto para ter o direito de uso de uma determinada área. Assim, a função de renda de um dado produto, admitindo que os preços das atividades agrícolas são dados, pode ser representada por:

$$
R=E(p-a)-E \cdot f \cdot k
$$

sendo:

$\mathrm{R}=$ renda por unidade de terra 
$\mathrm{k}=$ distância

$\mathrm{E}=$ rendimento por unidade de terra

$\mathrm{p}=$ preço de mercado por unidade de mercadoria

$\mathrm{a}=$ custo de produção por unidade de mercadoria

$\mathrm{f}=$ tarifa de transporte por unidade de distância para cada mercadoria

Pressupõe-se ainda que:

a) só se produzem produtos agrícolas;

b) os fatores de produção (com exceção da terra) são perfeitamente móveis e divisíveis (rendimentos de escala constantes);

c) os rendimentos da terra não variam sobre o espaço geográfico;

d) a oferta de fatores é abundante e a preços constantes;

e) a tarifa de transportes é constante no tempo e no espaço;

f) o abastecimento é voltado para apenas um único mercado consumidor;

g) a rede de transportes é uniforme.

Assim, a relação (1) pode ser representada graficamente conforme ilustrado na Figura 2:

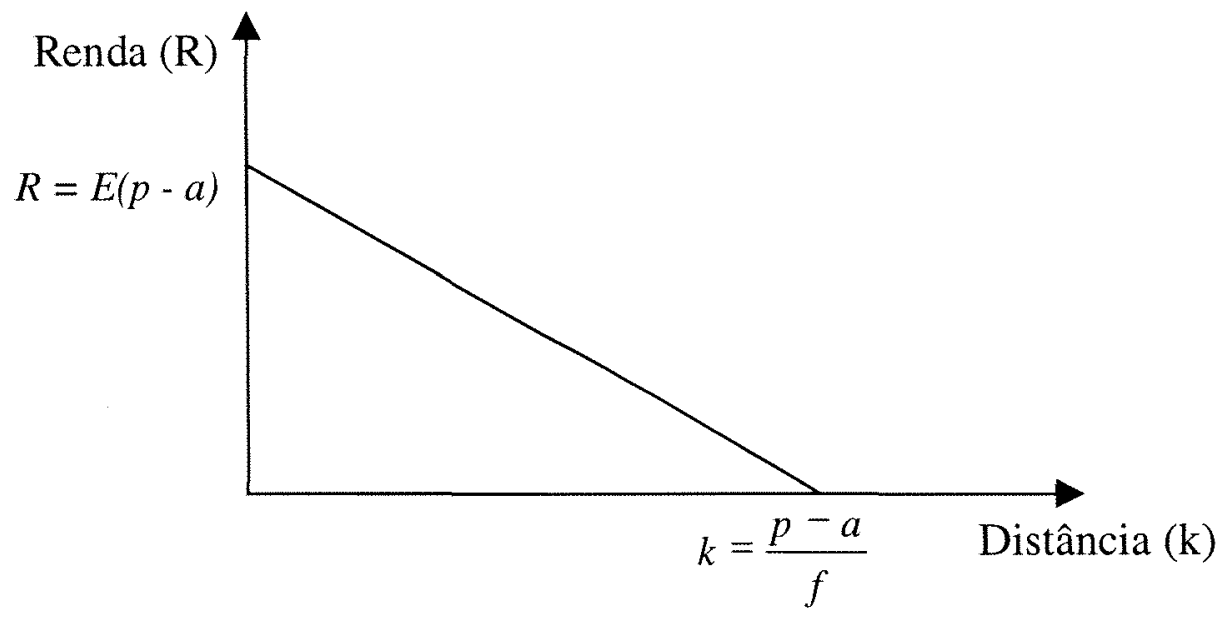

Figura 2 - Gradiente de Renda da Terra. Fonte: Ferreira (1989)

A Figura 2 é bastante intuitiva e mostra que uma propriedade localizada junto ao mercado consumidor (representada no gráfico pelo intercepto) tem uma renda igual ao 
preço líquido multiplicado pelo rendimento. Além disso, a taxa de variação desta renda com relação à distância é igual a:

$$
\frac{d R}{d k}=-E \cdot f
$$

ou seja, igual ao custo de transporte associado à produção de uma unidade de área.

Além disso, o ponto limite, onde a renda é nula, é encontrado quando a distância é igual à relação entre o preço líquido e a tarifa de transporte, ou seja:

$$
k=\frac{p-a}{f}
$$

A área do triângulo representa a renda total máxima que pode ser obtida de uma única atividade, considerando o conjunto de terras de uma região. A dedução matemática do porquê de esta área ser a renda total máxima pode ser encontrada em Ferreira (1989, p.130-4).

No caso de dois ou mais cultivos, a mesma área poderá sofrer concorrência para a sua ocupação e poderão ser formados os chamados anéis de von Thünen. Estes anéis representam faixas eqüidistantes do centro consumidor onde predomina uma determinada atividade. As condições para a sua formação são:

$$
E_{1}\left(p_{1}-a_{1}\right)>E_{2}\left(p_{2}-a_{2}\right)
$$

e

$$
\frac{p_{1}-a_{1}}{f_{1}}<\frac{p_{2}-a_{2}}{f_{2}}>0 ; \quad-E_{1} f_{1}<-E_{2} f_{2}
$$

Assim, para a existência dos anéis de von Thünen, as curvas de renda da terra dos vários produtos que competem pela mesma área têm que se cruzar e, para isto, se a renda líquida por unidade de área do produto 1 for maior que a do produto 2 (expressão 4), o 
custo de transporte da produção (e não apenas o custo por mercadoria) de 1 tem que ser também maior que o do produto 2. Além disso, a relação entre receita líquida e custo de transporte por mercadoria de 1 tem que ser menor que a de 2 e ambas devem ser positivas (expressão 5).

Portanto, os anéis de von Thünen representam a diferenciação locacional de produtos agrícolas para uma região de qualidade uniforme. No entanto, se as expressões $4 \mathrm{e}$ 5 não forem observadas, o que se terá é a dominância de um produto sobre o outro em toda a região, pois este terá a combinação de receita líquida maior e custo de transporte menor para todas as áreas, independente da distância do centro consumidor.

Na Figura 3 pode-se observar uma representação gráfica das curvas de renda da terra para dois produtos e dos respectivos anéis de von Thünen, mostrando as regiões onde há predominância do produto 1 e 2 de acordo com a distância para o mercado consumidor.

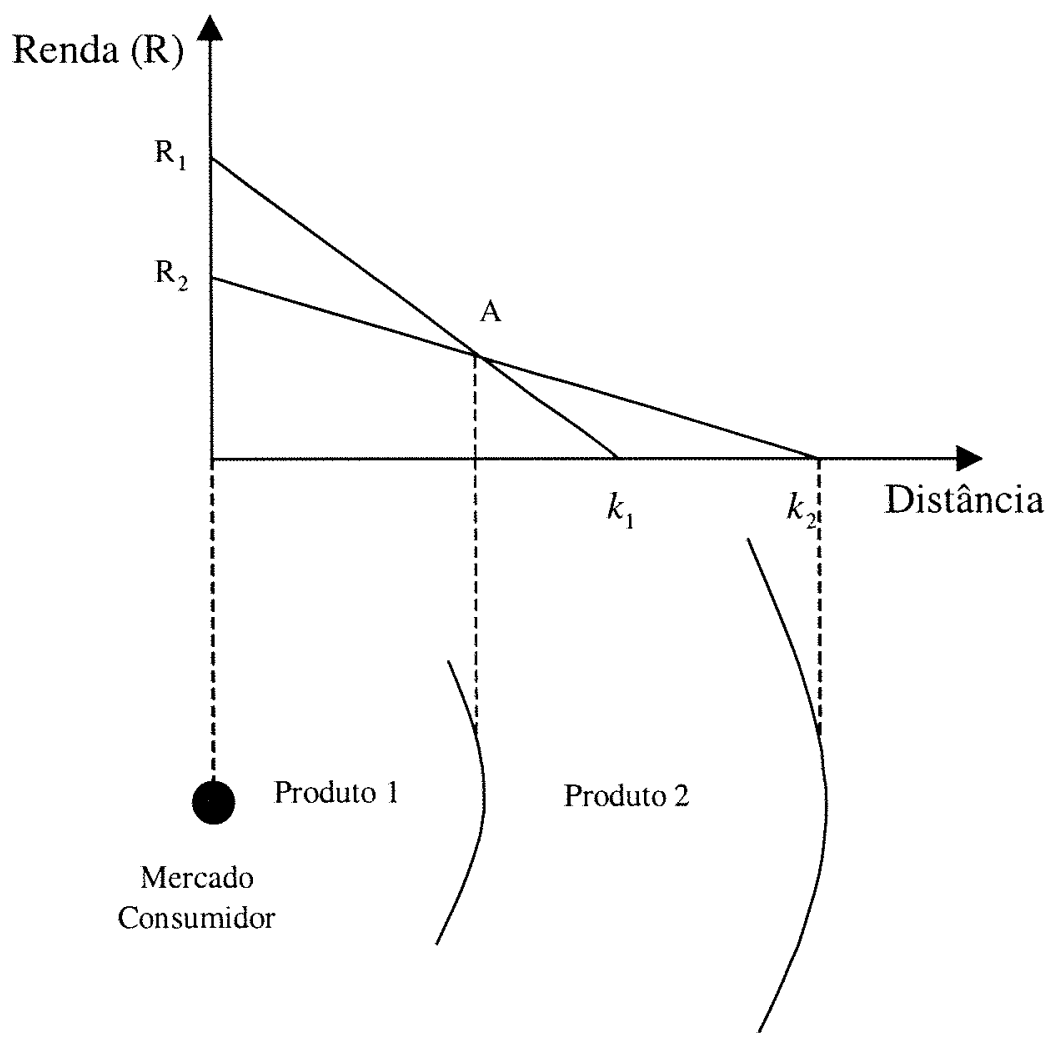

Figura 3 - Representação gráfica dos anéis de von Thünen 
No entanto, existem outros fatores que também influenciam o uso da terra, como topografia, fertilidade do solo, presença de mercados satélites ou concorrentes e presença de vias de transporte (Barlowe, 1965). Além destes, Kellerman (1989) cita também a cobrança de taxas para determinadas áreas, variações nos preços de mercado, diferenciação de preços, o transporte marítimo, diferenciação nos preços do frete com a variação da distância, consumidor como pagador pelo transporte, variação nos custos de produção, variação no tamanho das propriedades, presença de policultura, informação imperfeita e produtores com outros objetivos além da maximização dos lucros. Todos estes fatores fazem com que os anéis de von Thünen deixem de ser círculos concêntricos e passem a assumir as mais variadas formas, de acordo com as vantagens de cada produto para determinadas regiões.

Kellerman (1989) apresenta as variações na equação original de von Thünen (equação 1) decorrentes da observação dos fatores citados anteriormente. São apresentadas a seguir as mais relevantes:

\section{Taxação para produtos de outras regiões}

Este é o caso, por exemplo, do ICMS que é cobrado quando um produto sai de um determinado estado, ou das tarifas alfandegárias. Com a introdução deste fator, a equação 1 pode ser alterada para:

$$
R_{i j}=E_{i}\left(p_{i}-a_{i}\right)-E_{i} f_{i} k_{j}-E_{i} c_{i}
$$

sendo:

$i=$ produto agrícola

$j=$ determinada propriedade

$c_{i}=$ taxa de importação por unidade de produto

Assim, para produtores pertencentes à região do mercado consumidor, o valor de $c_{i}$ é zero, enquanto que para os demais é maior que zero. O resultado final desta taxação é a diminuição do raio dos anéis onde é cobrado este imposto. 


\section{Desuniformidade da qualidade de solo e clima}

O relaxamento da pressuposição de homogeneidade das condições de produção faz com que a teoria de von Thünen se aproxime da de Ricardo $(1951)^{5}$, citado por Kellerman (1989), que atribui à variação na fertilidade do solo as diferenças nas rendas locacionais de uma região. A implicação mais direta do relaxamento desta pressuposição é a variação na rentabilidade das áreas, determinada pela variação nas suas produtividades e nos seus custos de produção. A principal alteração na equação apresentada por Kellerman (1989) pode ser representada por:

$$
E_{i j}=b_{i j} E_{i}^{0}
$$

sendo:

$E_{i j}=$ produção de $i$ na localidade $j$

$b_{i j}=$ índice de variação na produtividade da cultura $i$ por conta dos fatores edafoclimáticos da localidade $j$

$E_{i}^{0}=$ produção da cultura $i$ em condições ideais de solo e clima

Assim, a produção $(E)$ varia de acordo com as condições locais através de um índice (b) que reduz o potencial produtivo de uma determinada cultura. $O$ índice $(b)$ é calculado de acordo com parâmetros tais como temperatura, precipitação, tipo de solo e outras variáveis ambientais que afetam a produção agrícola.

\section{Variações no preço do produto}

As variações nos preços decorrentes de quaisquer variações no mercado causam o efeito de deslocamento da curva de gradiente de renda da terra paralelamente à curva anterior, alterando assim apenas os valores dos interceptos (Figura 4). Nota-se que com um aumento de preço, a área do anel referente a este produto aumenta.

\footnotetext{
${ }^{5}$ Ricardo, D. On the Principle of Political Economy and Taxation. Londres: Ed. P. Sraffa, 1951
} 


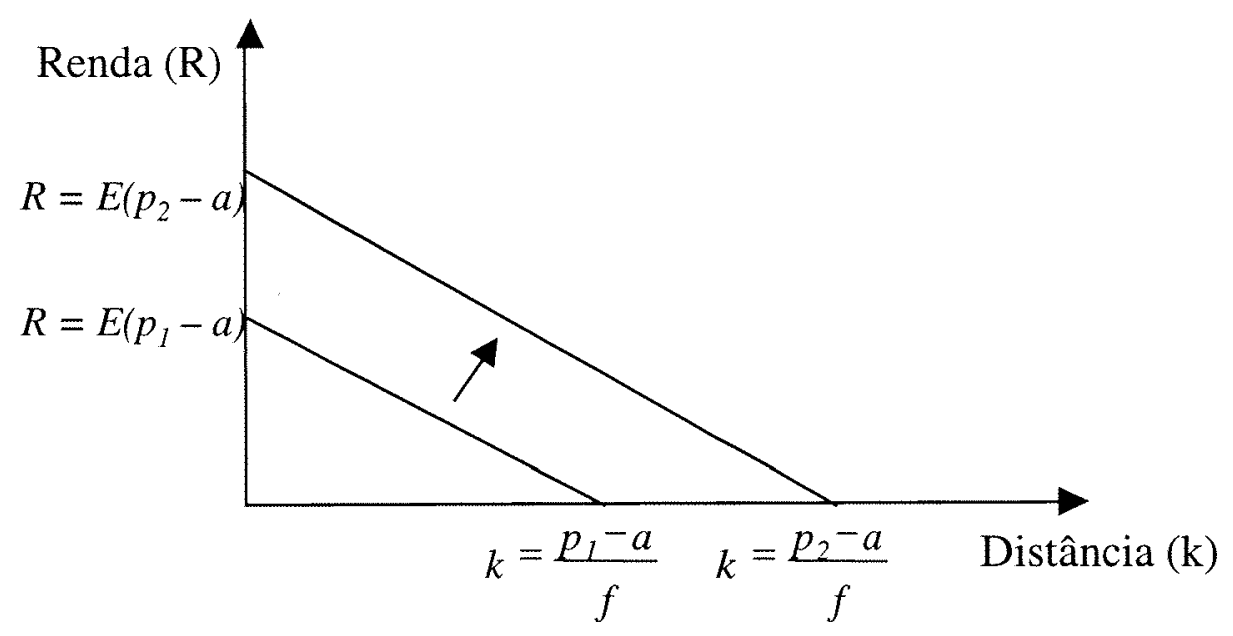

Figura 4. Impacto da variação nos preços no gradiente renda locacional de um produto

\section{Vários mercados consumidores}

Algumas regiões podem ser influenciadas por mais de um mercado consumidor que estejam dentro da zona economicamente viável para determinados produtos. A modificação na estrutura matemática é dada por:

$$
R_{i j g}=E_{i}\left(p_{i g}-a_{i}\right) E_{i} f_{i} k_{i g}
$$

ou seja, a renda de uma localidade será influenciada pelos vários mercados ( $g$ ) que estiverem próximos da localidade produtora $i$. Nota-se que as mudanças ocorrerão apenas nos preços e nas distâncias para o transporte. A Figura 5 ilustra o caso de dois mercados. 


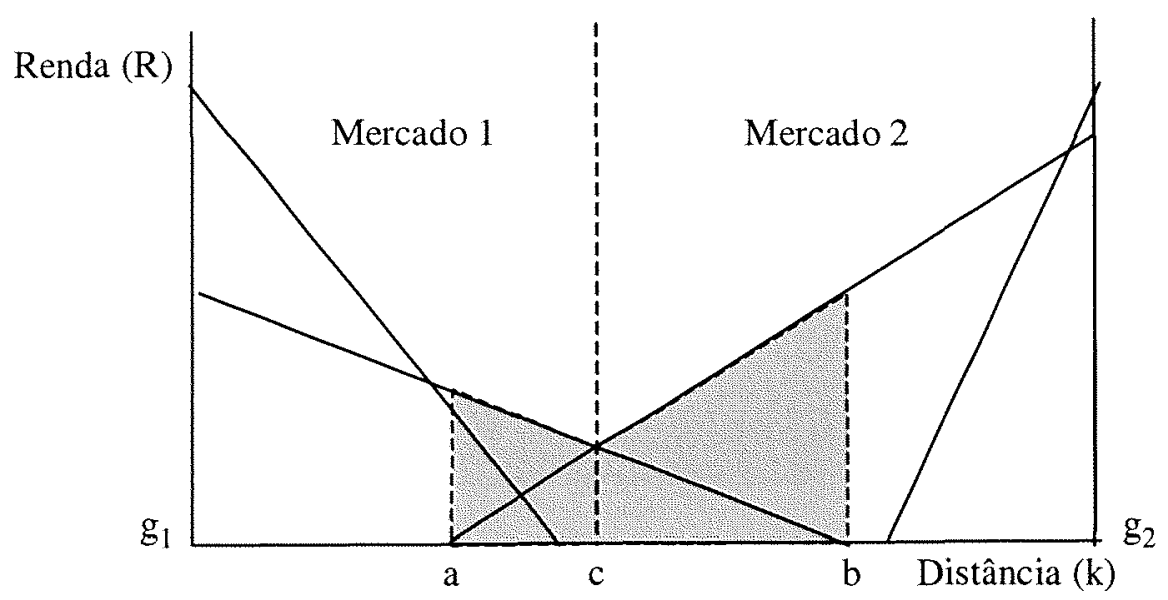

Figura 5 - Influência de dois mercados no uso da terra em uma determinada região. Fonte Kellerman (1989), citando Marble \& Anderson $(1972)^{6}$

Nota-se que as áreas que são influenciadas pelos dois mercados estão compreendidas entre os pontos $a$ e $b$ (área hachurada). $\mathrm{O}$ ponto $c$ é a fronteira que divide a influência dos dois mercados, ou seja, a propriedade que estiver sobre ele será indiferente quanto a qual mercado abastecer. Já uma outra propriedade à sua direita preferirá ofertar para o mercado 2 enquanto outra à esquerda terá preferência pelo mercado 1 .

\section{Diferentes superfícies de transporte}

A existência de vários modais diferentes (com preços de frete também diferentes), além de uma variação no próprio tipo de via (por exemplo, estrada asfaltada e estrada de terra) também alteram a amplitude dos anéis de von Thünen. Assim, vias de transporte com custos mais baixos (como as hidrovias) tendem a alongar os anéis, enquanto outros com custos mais altos (como estradas de terra) tendem a restringi-los. Kellerman (1989), citando novamente Marble \& Anderson (1972), utiliza uma função que reduz a distância de vias com transporte mais barato (como auto-estradas) para poder manter os preços do frete homogêneos, como pode-se observar na relação seguinte:

\footnotetext{
${ }^{6}$ Marble, D. F.; Anderson, B. M. Landuse: A Computer Program for Laboratory Use in Economic Geography Courses. Commission on College Geography Technical Papers 8. Washington: Association of American Geographers, 1972.
} 
$k_{e}=\mu k_{g}$

onde:

$k_{e}=$ distância da via utilizada no modelo (equivalente em custo à via utilizada como padrão)

$\mu=$ coeficiente de equivalência com via padrão

$k_{g}=$ distância efetiva percorrida até $g$ através da via de transporte mais barata

Stone (1998) chamou o coeficiente $(\mu)$ de coeficiente de fricção, utilizando-o para os diversos tipos de transporte da Amazônia.

\section{Momento de transporte variável}

Sabe-se que os preços de frete por tonelada e por quilômetro (chamado de momento de transporte), qualquer que seja o modal, tende a ser menor na medida em que se aumenta a distância percorrida. Esta característica faz com que a renda em áreas mais distantes seja maior que em situações em que o momento seja constante, permitindo que os anéis sejam mais amplos.

\section{Custo de produção variável}

Diferentemente da variação nas condições de qualidade produtiva, que foram anteriormente comentadas, neste caso o custo de produção varia com a distância, através de diferenças na adoção de tecnologia e nos salários. No primeiro caso, a utilização de novas tecnologias intensificam o uso da terra e exigem menos área, o que reduz o raio dos anéis. Já quanto aos salários, pressupõe-se que à medida que se distancia do centro consumidor, os salários decrescem, devido a uma menor competição com os salários urbanos. Neste caso, a tendência é que os anéis tenham maiores raios. 


\section{Tamanho diferenciado das propriedades e policultura}

A diferenciação do tamanho das propriedades tem um efeito bastante substancial, pois sabe-se que a agricultura tem ganhos de escala. Assim, quanto maior a propriedade, menos impacto nos custos totais terão os custos fixos, deixando o custo por unidade de área menor. Assim, com maior escala de produção permite-se produzir em regiões mais distantes do centro consumidor.

Já a policultura é um fator de redução de riscos para o produtor e a quantidade de produtos tende a ser tanto maior quanto mais distante do centro se estiver. Como produtores mais distantes têm menores rendas e estão sujeitos a menores riscos, eles optam por diversificar para minimizar eventuais perdas.

\subsection{Aplicações da teoria de von Thünen}

A teoria de von Thünen vem sendo utilizada em vários trabalhos, tanto com enfoques em Geografia quanto em Economia. Kellerman (1989) apresenta uma vasta lista de trabalhos desenvolvidos em todo o mundo, principalmente nos países do terceiro mundo. No entanto, ele cita dois vieses destes trabalhos: i) somente utilizaram a teoria de von Thünen, quando a de Ricardo às vezes é mais apropriada; e ii) não trabalharam com tipos de agricultura mais complexos (normalmente estudam somente a agricultura de subsistência).

O’Kelly \& Bryan (1996) também listaram vários trabalhos que utilizam esta metodologia, classificando-os em quatro grupos: i) os que buscavam evidências empíricas para a teoria de von Thünen em trabalhos históricos; ii) os que estudavam aspectos econômicos para a formação dos anéis; iii) os que estudavam aspectos comportamentais para a formação dos anéis; e iv) os que utilizavam programação matemática.

Um outro modelo que utiliza esta mesma base teórica foi elaborado por Hanink (1995), que se baseou nas idéias de renda locacional da terra para relacionar escassez de recursos a partir da existência de desertos. 
MacMillan (1992) introduz à abordagem de von Thünen uma análise de risco baseada no critério da média-variância. Assim, relaxa-se a pressuposição de que a maximização de lucros é o único objetivo do produtor.

Já a pressuposição de não taxação é relaxada por Jones \& O'Neill (1993), que elaboram um modelo que considera as externalidades atmosféricas e os desmatamentos decorrentes de eventos que estimulem o avanço da agricultura e impõe um imposto corretivo sobre a renda locacional da terra. Eles concluem que esta taxação não reverte o processo de avanço da agricultura, mas reduz a sua intensidade.

Jones \& O'Neill (1994) analisaram os efeitos de algumas políticas sobre a expansão da fronteira agrícola. Para isto, utilizaram um modelo de dois setores (urbano e rural) com uma zona rural característica do modelo de von Thünen. Os autores concluem que políticas de desenvolvimento de transportes na zona rural tendem a receber grande apoio, pois estimulam a interiorização do desenvolvimento. No entanto, estas políticas também favorecem o desmatamento de novas áreas. Eles identificaram também que algumas políticas setoriais urbanas geram impactos substanciais no setor rural.

Na mesma linha, Wang \& Guldmann (1997) desenvolveram um modelo de equilíbrio espacial para dois setores, também baseado nas idéias de von Thünen, com o intuito de determinar, através do equilíbrio entre os dois mercados (rural e urbano), i) o tamanho da região, ii) a taxa de urbanização e a população da cidade e iii) a estrutura da zona rural.

Hsu (1997) desenvolve uma metodologia para o estudo da localização de agroindústrias. A grande diferença deste setor para os outros setores industriais é o fornecimento de matéria-prima, que neste caso é feito pela agricultura. Por isto, na metodologia proposta pelo autor, o setor agrícola é modelado de acordo com as pressuposições de von Thünen.

Já Smith et al. (1997) utilizaram um modelo de uso da terra para a Amazônia e para o cerrado brasileiro com o objetivo de analisar o impacto de políticas e o desenvolvimento de novas tecnologias nas mudanças no uso da terra nestas duas regiões até o ano 2020. As 
conclusões destes autores é que, mesmo com políticas públicas favoráveis e com o desenvolvimento de tecnologias ambientalmente benéficas, os desmatamentos para a introdução de pastagens e agricultura de corte e queima continuarão a existir. $\mathrm{Na}$ Amazônia, a agricultura terá um crescimento que varia de $50 \%$ a $415 \%$, podendo ocupar uma área que variaria de 3 a 10 milhões de hectares (dependendo, basicamente, do sucesso ou fracasso do Plano Real e do desenvolvimento de corredores de exportação na Amazônia). Esta área corresponde a cerca de $2,15 \%$ a $7,15 \%$ da área plantada com soja no Brasil em 2000. No entanto, uma grande porcentagem continua sendo composta pela agricultura de corte e queima, ficando para a agricultura comercial uma área que variaria de 150 mil ha a 5 milhões de ha.

Araujo (1994) utiliza o modelo de von Thünen para estudar a renda locacional da terra para cinco culturas e três períodos de tempo, tendo como mercado central a Grande São Paulo. Os resultados indicam que a hipótese de redução da renda locacional da terra em decorrência do aumento da distância para o mercado consumidor não deve ser rejeitada, significando que a teoria de von Thünen é válida neste caso.

Para o setor madeireiro, Stone (1998) utilizou um modelo em que considerava as diferenças nos custos de transporte devido aos diferentes canais de escoamento do estado do Pará (rios, rodovias asfaltadas, rodovias não asfaltadas e estradas vicinais) para verificar o alcance econômico da exploração madeireira deste estado em três estratos: apenas mogno, com exploração bastante seletiva (regiões mais distantes dos pólos madeireiros); madeiras de médio valor e mogno, com exploração seletiva (regiões intermediárias) e todas as madeiras, com exploração intensiva (regiões mais próximas). Neste caso, os dados utilizados (e devidamente mapeados em um Sistema de Informações Geográficas - SIG) foram relativos à infra-estrutura de transportes, à localização dos pólos madeireiros do estado, aos preços das diferentes madeiras nestes pólos, à atual utilização da terra das diversas regiões do Pará e às regiões com presença de mogno.

Os dados mapeados foram utilizados como matrizes, ou seja, o mapa é dividido em inúmeras células de um tamanho determinado (neste caso $1 \mathrm{~km}^{2}$ ) e cada célula se torna uma variável do modelo. Desta forma, pode-se sobrepor os mapas em camadas e cada célula tem 
um valor específico para a distância até o pólo, a atual utilização da terra e a presença ou não de mogno. Estes dados serviram como restrições na estrutura matemática.

Por fim, Stone (1998) elaborou um modelo de programação linear onde maximiza o lucro das madeireiras sujeito às suas restrições de capital e capacidade de processamento de madeira, além das restrições naturais, representadas pelos mapas anteriormente citados. O mesmo autor também tornou este modelo dinâmico, pois a introdução da variável tempo foi necessária na medida em que ao se explorar uma área, o acesso fica mais fácil e reduz-se o custo de transporte.

O modelo utilizado neste trabalho é semelhante ao usado por Stone (1998), mas não é dinâmico e apresenta algumas alterações devido às diferenças entre a atividade madeireira e a produção de soja.

\subsection{Especificação do modelo proposto}

O presente trabalho também utilizará um modelo de programação linear de maximização de lucros com as equações formuladas por von Thünen. No entanto, foi utilizado apenas um produto, a soja, não permitindo a construção de todos os anéis referentes ao uso do solo na Amazônia. Com isso, pressupõe-se que a soja será uma cultura mais rentável que as outras atividades atualmente desenvolvidas na Amazônia, como pecuária, extração madeireira, agricultura familiar e outros tipos de agricultura comercial. Esta consideração superestimou o anel deste produto, pois em regiões mais distantes, provavelmente, outras atividades serão mais rentáveis. Assim, os resultados deste trabalho não mostrarão as regiões onde a soja será mais competitiva, mas sim onde ela será economicamente viável na Amazônia devido às atuais melhorias na infra-estrutura de transporte.

Portanto, a estrutura matemática do modelo será a seguinte:

$\operatorname{Max} \quad \sum_{i} R_{i}=\sum_{j}\left(E_{i j} p_{j}\right)-C P_{i}-E_{i j} f_{t} k_{t i j}$ 
sujeito a

$$
\begin{aligned}
& \sum_{i} E_{i j} \leq C_{j} \\
& E_{i j}=0, \text { para áreas restritas ao uso agrícola } \\
& C P_{i}=Q_{i z} p_{x z}+Q_{i z} f_{t} k_{t i x}+C O_{i}+\frac{Q_{i c} p_{x c}+Q_{i c} f_{t} k_{t i x}+C C_{i}}{n_{i}}+\frac{C A_{i}}{m_{i}} \\
& \sum_{j} E_{i j} \leq P t_{i} \\
& \sum_{i} E_{i j} \leq D_{j} \\
& R_{i} \geq 0 \\
& E_{i j} \geq 0
\end{aligned}
$$

sendo:

$i$ = índice associado à localidade produtora;

$j$ = índice associado ao demandante de soja (porto exportador ou agroindústria);

$t=$ índice associado aos modais de transporte (rodoviário, ferroviário, hidroviário e portuário);

$z=$ índice associado ao fornecedor de insumos;

$c=$ índice associado ao fornecedor de calcário;

$R_{i}=$ renda obtida com a soja para cada localidade $i$, em $\mathrm{R} \$$

$E_{i j}=$ produção da localidade $i$ destinada ao demandante $j$, em t;

$p_{j}=$ preço da soja pago pelo demandante em $j$, em $\mathrm{R} \$ / \mathrm{t}$;

$C P_{i}=$ custo de produção da soja na localidade $i$, em $\mathrm{R} \$ / 100$ ha;

$f_{t}=$ momento de transporte para o modal $t, \mathrm{em} \mathrm{R} \$ / \mathrm{t} \mathrm{km}$;

$k_{t i j}=$ distância percorrida no modal $t$ para ir da localidade $i$ ao demandante $j$, em km;

$C_{j}=$ capacidade máxima anual de transporte para o destino $j$, em $\mathrm{t}$;

$Q_{i z}=$ quantidade do insumo $z$ exigida na localidade $i$, em $\mathrm{t}$;

$p_{x z}=$ preço do insumo $z$ no vendedor $x, \mathrm{em} \mathrm{R} \$ / \mathrm{t}$; 
$k_{t i x}=$ distância percorrida no modal $t$ para ir do vendedor $x$ para a localidade $i$, em $\mathrm{km}$;

$C O_{i}=$ somatória dos custos operacionais para a produção de soja em $i$, em $\mathrm{R} \$ / 100$ ha;

$Q_{i c}=$ quantidade de calcário exigida na localidade $i, \mathrm{em} \mathrm{t}$;

$p_{x c}=$ preço do calcário no vendedor $x, \mathrm{em} \mathrm{R} \$ / \mathrm{t}$;

$C C_{i}=$ somatória dos custos de aplicação do calcário na localidade $i$, em $\mathrm{R} \$ / 100$ ha;

$n_{i}=$ número de anos entre duas aplicações de calcário em $i$;

$C A_{i}=$ custo de abertura de área na localidade $i$, em $\mathrm{R} \$ / 100$ ha;

$m_{i}=$ número de anos que se espera o retornar o investimento de abertura de área;

$P t_{i}=$ produção de soja em $i$, em t;

$D_{j}=$ demanda por soja em $j \mathrm{em} \mathrm{t}$.

A equação (9) é a maximização da receita de cada localidade $i$, sendo ela obtida a partir da somatória das receitas obtidas com cada demandante $j$. É importante notar que a pressuposição de diferenciação de modais foi relaxada, pois os momentos de transporte $\left(f_{t}\right)$ para cada modal são diferentes. Além disso, eles variam também dentro do próprio modal, pois as características operacionais de cada via são diferenciadas. No entanto, o momento de cada via não varia com a distância, o que mantém o pressuposto de momento de transporte constante. Por fim, a pressuposição de mercado consumidor único também não é utilizada por este modelo, permitindo a competição de dois ou mais demandantes pela soja de uma determinada região.

A equação (10) representa as restrições de alguns modais quanto ao máximo de carga transportada. Este parâmetro é especialmente limitante para as hidrovias, pois apresentam uma capacidade operacional menor que a dos demais modais.

Para as áreas onde existirem algum impedimento técnico, como relevo que inviabiliza a mecanização, ou impedimento legal, como reservas indígenas e parques nacionais, o modelo assume que a produção de soja seja nula. Esta restrição está representada pela equação (11) e relaxa também a pressuposição de livre acesso e homogeneidade das áreas. 
Já a equação (12) mostra o método que será utilizado para se calcular o custo de produção de cada localidade $i$. Ele será composto pelos custos de compra e transporte de insumos, de operações, de aplicação de calcário (neste caso dividido pelos $n$ anos em que persistem os efeitos de uma calagem no solo) e de abertura da área (dividido pelos anos em que se espera recuperar o investimento). Este último custo só será relevante para regiões ainda não desmatadas e será diferenciada pelo tipo de vegetação (cerrado/capoeira, floresta secundária e floresta primária). Aqui a pressuposição de superfície homogênea é relaxada, pois o custo será diferenciado para cada tipo de solo. Esta diferenciação se dará através da variação na utilização de insumos de acordo com as necessidades de cada solo, implicando também em custos diferentes.

O limite de produção de cada localidade $i$ está apresentado na equação (13). Este limite será calculado como a produtividade de uma determinada localidade multiplicada pela área padrão utilizada por este modelo (100 ha), ou seja, este modelo não relaxará a pressuposição de tamanho único das propriedades e nem a de monocultura, mas relaxará novamente a de homogeneidade, pois para cada tipo de solo estará associada uma certa produtividade.

A equação (14) representa a restrição de demanda. No caso dos portos exportadores, esta restrição não deve ser atuante, pois pressupõe-se que a Amazônia tenha vantagens comparativas para a exportação sobre os outros mercados do Brasil e do exterior. Além disso, o crescimento populacional e, consequentemente, do consumo de carnes, tem feito com que analistas do mercado prevejam uma expansão no mercado internacional da soja (Pavan, 1997; GEIPOT, 1999; Sugai et. al., 1998; Roessing, 1998; além de projeções do USDA e ABIOVE). Assim, assume-se que a Amazônia sempre encontrará espaço para o escoamento de sua soja no mercado internacional. No entanto, já existem algumas plantas esmagadoras na região, além de outras já previstas, que podem influenciar algumas localidades para a produção de soja. Neste caso, a demanda considerada é a estimativa de produção anual, que foi calculada com base nos dados de capacidade instalada.

Por fim, as equações (15) e (16) representam as restrições de positividade para a renda $R_{i}$ e para a produção $E_{i j}$, as variáveis endógenas do modelo (além destas duas variáveis, apenas o custo de produção também é variável endógena). Tais restrições 
implicam em renda $\left(R_{i}\right)$ e produção de cada localidade $\left(E_{i j}\right)$ obrigatoriamente positivas, o que basicamente determina os limites do alcance econômico da soja na Amazônia.

Na próxima seção é apresentado o método de cálculo utilizado para a solução deste modelo, que não utilizou nenhuma linguagem específica de otimização, bem como a especificação dos dados utilizados.

\subsection{Especificação dos dados e método de cálculo}

As informações utilizadas estão divididas em duas base de dados: i) mapas georeferenciados e ii) dados coletados em visitas de campo, com complementação de dados secundários.

No primeiro caso, foram utilizados os mapas (com abrangência para toda a Amazônia Legal) de solos, vegetação, áreas protegidas, malha rodo, hidro e ferroviária, portos, divisão política dos estados e sedes municipais. Estas informações foram coletadas junto ao Instituto do Homem e do Meio Ambiente da Amazônia (IMAZON).

É importante notar que o mapa de áreas protegidas só serviu para restringir algumas áreas onde não será permitido o plantio de soja. No entanto, os mapas de vegetação, áreas antrópicas (desmatadas) e solos servem como base para a inserção dos dados de produtividade, custo de sistematização, necessidade de adubo e calcário e outros custos de produção (mapa de solos), além dos dados de custo de abertura de área (mapas de vegetação e áreas antrópicas). Assim, à cada classe (tipo de solo ou de cobertura vegetal) destes mapas são atribuídos valores específicos. Além disso, especificamente para os dados de custos de produção, produtividade e necessidade de calcário e adubo, a variação dos dados também se dá entre as regiões, podendo um Latossolo Amarelo do estado do Amazonas, por exemplo, ter valores diferentes de um outro do estado do Pará. O mesmo não ocorre com o custo de abertura de área, que é o mesmo, independente da região.

Todas estas informações (custo de abertura de área, outros custos de produção, utilização de insumos e produtividade) foram coletadas nas visitas de campo. Os valores utilizados para o cenário base apresentado nos resultados podem ser encontrados no Apêndice 2. 
Foi utilizado para a elaboração e tratamento matemático dos dados o programa ArcView (Lane, 1991), que permite a utilização dos dados já mapeados para os cálculos. No entanto, este programa tem a limitação de não possuir nenhuma rotina de otimização. Isto exigiu a elaboração de uma rotina de cálculo com as ferramentas do ArcView que, apesar de não garantir o valor ótimo, possibilita a obtenção de valores bastante próximos ao máximo, além de permitir o cumprimento das restrições pertinentes.

A utilização de dados geo-referenciados já é bastante comum em diversas áreas do conhecimento. Foram encontrados através do sistema de busca "Web of Science", 148 trabalhos entre os anos de 1991 e 1999 utilizando esta ferramenta. As utilizações variavam desde planejamento do uso de ambulâncias até a identificação das melhores áreas para se construir uma estrada. Os principais tópicos dos trabalhos encontrados estão apresentados na Tabela 17.

Tabela 17. Tópicos principais dos trabalhos do período de 1991 a 1999 que utilizam sistema de informação geográfica como ferramenta, segundo o sistema de busca "Web of Science".

\begin{tabular}{|c|c|c|}
\hline \multicolumn{2}{|r|}{ Tópico } & Número de trabalhos encontrados \\
\hline- & Ecologia & 46 \\
\hline- & Recursos hídricos & 23 \\
\hline- & Planejamento do uso da terra & 20 \\
\hline- & Manejo agropecuário e florestal & 16 \\
\hline- & $\begin{array}{l}\text { Construção de estradas, transporte e } \\
\text { logística }\end{array}$ & 14 \\
\hline- & Saúde pública & 11 \\
\hline- & $\begin{array}{l}\text { Potencial de erosão e movimentação de } \\
\text { nutrientes no solo }\end{array}$ & 6 \\
\hline- & Planejamento do serviço de saúde & 5 \\
\hline- & Planejamento urbano & 5 \\
\hline- & Dispersão de poluentes & 4 \\
\hline- & Outros & 7 \\
\hline TOTA & & 148 \\
\hline
\end{tabular}

Fonte: Web of Science, fevereiro de 2000

\footnotetext{
${ }^{7} \mathrm{O}$ "Web of Science" é um serviço na Internet restrito a assinantes, que busca artigos científicos em mais de 8.400 publicações internacionais de todas as áreas do conhecimento.
} 
Doze destes trabalhos utilizam otimização em seus modelos, mas nunca somente com o ArcView. Estes trabalhos utilizam sempre o ArcView para a visualização e um tratamento mais simples dos dados, utilizando linguagens de programação para a otimização. Nestes casos, o otimizador é alimentado com as informações do banco de dados do ArcView para depois retornar os resultados para este mesmo banco de dados, permitindo a confecção dos mapas finais.

Cao et al. (1999) desenvolveram um modelo utilizando SIG e otimização combinatória para a criação de uma plataforma computacional para a tomada de decisão na construção de redes de cabos de telefones. Para facilitar a entrada dos dados e a visualização dos resultados, foi criada uma interface que permite ao usuário uma melhor interação com o programa, mas sem deixar de exigir a elaboração de uma rotina de cálculo, externamente à plataforma de SIG.

Num trabalho realizado na Costa Rica, Bouman et al. (1999) desenvolveram durante 10 anos um modelo quantitativo de análise do uso da terra e dos impactos da agricultura sobre o meio ambiente, baseando-se em parâmetros técnicos observados em campo. Este modelo utiliza os dados observados para gerar parâmetros que são utilizados em simulações de eventuais políticas. Estes parâmetros abastecem um modelo de otimização econômico e biofísico e os resultados obtidos são visualizados numa plataforma de SIG. Este instrumental vem sendo utilizado para a busca de políticas e tecnologias ambientalmente e economicamente sustentáveis na Costa Rica.

Uma outra utilização de otimização em conjunto com SIG pode ser observada no trabalho de Stoms et al. (1998). Neste trabalho, os autores desenvolvem uma metodologia para a escolha das melhores áreas naturais para pesquisa ("Research Natural Area" - RNA), baseando-se em inúmeros parâmetros de vegetação e variações ambientais. Assim, é possível se ter um critério quantitativo para a escolha dos locais destinados à pesquisa.

Já Qiu et al. (1998) utilizaram simulação e SIG para reduzir a utilização de herbicidas nas lavouras através da melhor regulagem dos bicos aplicadores de herbicida de acordo com os parâmetros ambientais de cada trecho estudado (textura do solo, teor de matéria orgânica e potencial de produção). Para o tratamento dos dados utilizou-se o 
modelo SLAM II e os resultados foram inseridos numa plataforma SIG para melhor visualização.

O trabalho anteriormente citado de Stone (1998) também utiliza um modelo de otimização vinculado a um SIG para o setor madeireiro na Amazônia. A otimização é feita de maneira bastante simples, transformando os dados dos mapas finais em planilhas eletrônicas e fazendo as restrições atuarem manualmente. Após o processamento dos dados na planilha eletrônica, os dados voltam para uma plataforma SIG e formam os mapas finais. Como já mencionado anteriormente, a metodologia do presente trabalho foi baseada no trabalho de Stone (1998), com algumas adaptações no modelo e no procedimento de cálculo para o setor da soja.

$\mathrm{Na}$ Índia, George et al. (1997) utilizaram redes neurais acopladas a um SIG para observar o impacto de políticas de desenvolvimento sobre o meio ambiente. O sistema de redes neurais é dividido em duas partes, sendo primeira utilizada para prever os impactos ambientais resultantes das variações no ambiente econômico e a segunda para prever o ganho ou perda de qualidade de vida decorrente do desenvolvimento econômico. Neste trabalho, o SIG é também utilizado como fornecedor de dados para o modelo e como visualizador dos resultados.

Begur et al. (1997) desenvolveram uma ferramenta de otimização para o escalonamento de enfermeiras que atendem a domicílio. Esta ferramenta utiliza uma heurística sobre a plataforma de SIG, permitindo que as soluções ótimas de horários e rotas a serem percorridas pelos enfermeiros sejam facilmente observadas em mapas.

Um enfoque semelhante foi utilizado por Walsh et al. (1997) para a previsão da utilização de ambulâncias de um centro médico. O SIG foi utilizado em conjunto com a otimização do tempo de transporte baseado em modelos de roteirização.

Nevo e Garcia (1996) desenvolveram em uma plataforma UNIX um modelo não linear para a otimização da cobertura vegetal de uma região para determinado estado desejável num habitat natural. Este sistema é todo integrado e utiliza o SIG para a visualização dos resultados. 
Para o planejamento de sistemas de abastecimento de água em cidades, Taher e Labadie (1996) desenvolveram um sistema computacional para auxiliar os engenheiros com as alterações temporais de demanda e outros fatores no desenho da rede de abastecimento. $\mathrm{Da}$ mesma forma que os trabalhos anteriores, neste caso o SIG é ligado a um software otimizador que processa os dados e retorna os resultados para serem visualizados na forma de mapas.

Considerando ainda o manejo de recursos hídricos, Brusven et al. (1995) utilizaram um modelo chamado de "agricultural nonpoint source", que utiliza programação inteira mista, aliado ao SIG para identificar os impactos de diversas práticas agrícolas na erosão dos solos e, consequentemente, no assoreamento do rio Snake, no noroeste dos Estados Unidos.

Vadas et al. (1995) desenvolveram uma metodologia para monitorar a qualidade e quantidade da água de pântanos baseado em informações multidisciplinares coletadas em campo. O modelo proposto utiliza o otimizador GAMS/MINOS em conjunto com o SIG e com um módulo de simulação, criando uma ferramenta para a tomada de decisão frente ao uso dos recursos hídricos destas áreas.

Xiang (1993) desenvolveu um programa que permite que vários técnicos possam trabalhar coordenadamente num mesmo problema utilizando SIG e programação multiobjetivo. Ele utilizou esta ferramenta para um projeto de planejamento ambiental.

Diferentemente destes trabalhos que utilizam otimização e SIG, desenvolveu-se para este modelo, que matematicamente é bastante simples, um método de cálculo específico utilizando apenas o programa ArcView. Optou-se por este caminho pela simplicidade da estrutura matemática e pela dificuldade de transposição dos dados do ArcView para qualquer outro software (o tamanho do banco de dados é bastante abrangente, já que cada mapa contém mais de 8 milhões de células). Como o limite de colunas de uma planilha eletrônica é de apenas 256 colunas, isto inviabiliza a transposição dos dados da mesma forma que Stone (1998). 
Assim, o procedimento de cálculo desenvolvido para este trabalho consiste de três fases: i) elaboração dos mapas de preços dos insumos e da soja; ii) elaboração do mapa de receita líquida e iii) incorporação das restrições.

A primeira fase está esquematizada na Figura 6.

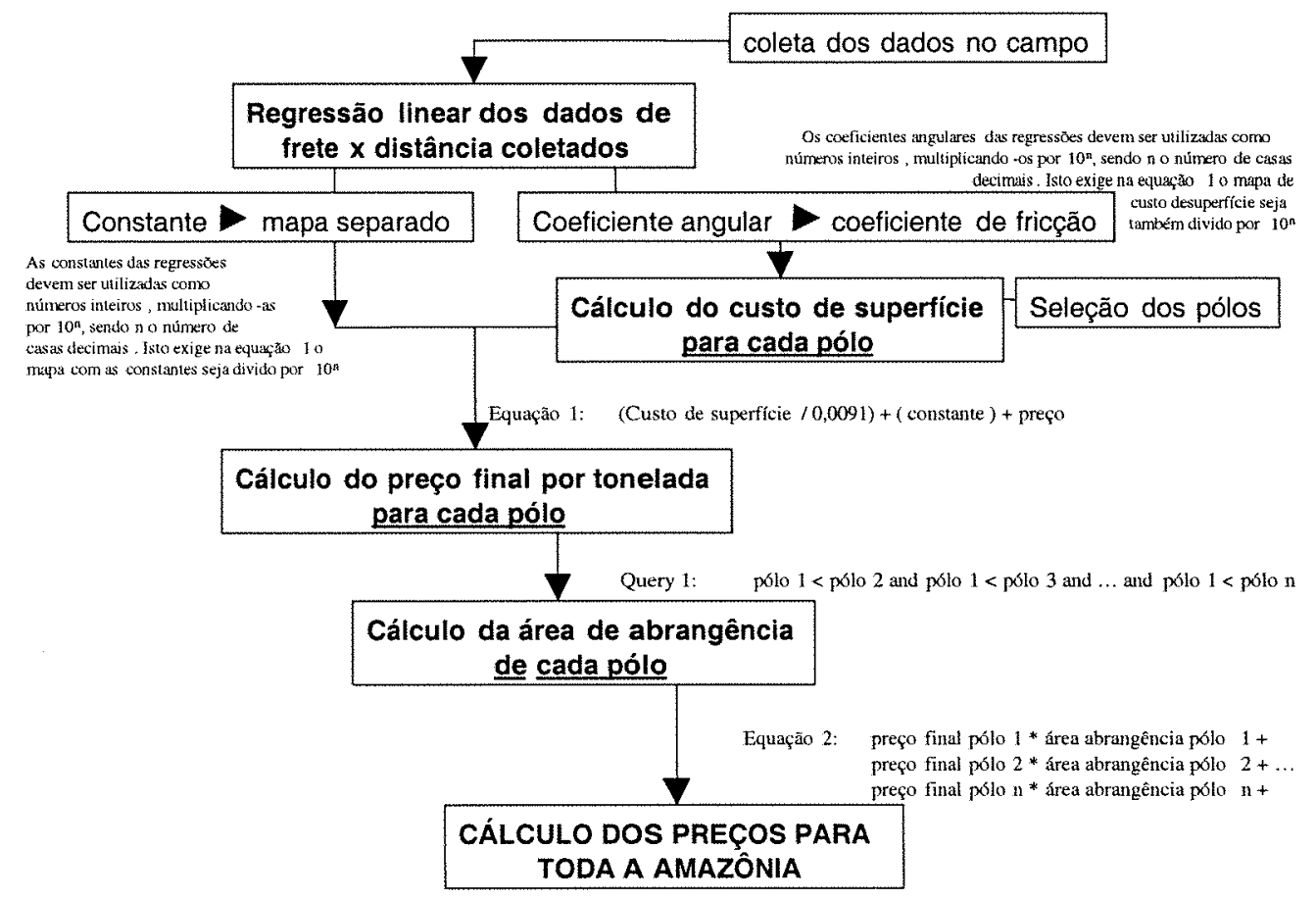

Figura 6. Fluxograma para a confecção dos mapas de preços de adubo, calcário e soja

O processo inicia-se com o tratamento dos dados de frete coletados no campo. Estes dados são agrupados em regiões para, a partir das mesmas obter-se uma equação com a regressão dos fretes relacionados com as respectivas distâncias percorridas. Estas equações podem ser visualizadas no Apêndice 2. Algumas regiões não tiveram informações suficientes para se fazer uma regressão. Nestes casos, utilizou-se o momento de transporte como coeficiente angular enquanto o coeficiente linear foi considerado como igual a zero.

Com a obtenção destas equações, parte-se para o cálculo dos custos de transporte, que foi efetuado em duas etapas: i) utilização da ferramenta de Custo de Distância (CostDistance) do programa ArcView e ii) adição do coeficiente linear. 
Na primeira etapa calculou-se o custo de transporte para cada célula a partir de um pólo, utilizando para isto a ferramenta de Custo de Distância (CostDistance). O cálculo feito por esta ferramenta é simplesmente a somatória dos menores custos de transporte a partir de um pólo (que pode ser um fornecedor de insumos, no caso dos mapas de calcário e adubo, ou um demandante de soja no caso do mapa da soja). Os coeficientes angulares encontrados anteriormente são multiplicados pela distância até o pólo (determinada automaticamente pelo programa) e somada ao menor custo das células do entorno. O mapa resultante apresenta os resultados em $\mathrm{R} \$$ por unidade de mapa e a conversão para $\mathrm{km}^{2}$ (cada célula representa $1 \mathrm{~km}^{2}$ ) é feita com a divisão de todas as células por 0,0091. Ou seja, cada unidade de mapa tem área 110 vezes menor $(1 / 0,0091)$ que seu tamanho real $\left(1 \mathrm{~km}^{2}\right.$ ou 100 ha).

Por fim, é necessário somar os coeficientes lineares, apresentados em um mapa separado. Após esta última operação, temos o mapa de custo de transporte de um determinado pólo para todas as outras localidades da Amazônia. Este processo foi repetido para todos os 36 pólos utilizados neste trabalho (3 para o mapa de preço do adubo, 22 para o mapa de preço do calcário e 11 para o mapa de preços da soja).

Sobre o mapa de custo de transporte, soma-se também o preço pago ou recebido nos diversos pólos para o calcário, para o adubo e para a soja. Isto também é feito pólo a pólo, pois os preços de cada pólo são diferentes entre si. Os resultados dizem respeito a 36 mapas (3 para adubo, 22 para calcário e 11 para a soja) com o preço dos produtos em cada localidade da Amazônia, tendo como fornecedor ou receptador apenas um dos pólos.

Para se chegar aos mapas finais, que agregam apenas os preços mais competitivos de cada pólo para os três produtos, é necessário utilizar a ferramenta "Query"8 que elabora uma condição para criar o mapa apenas com a área de influência de cada pólo. A área de influência é aquela em que os preços de um pólo são melhores (mais baixos para os insumos e mais altos para a soja) que todos os demais outros pólos.

\footnotetext{
${ }^{8}$ A ferramenta "Query" cria um mapa com valores binários (com 0 e 1 apenas) onde é atribuído o valor 0 para as células que não respeitarem a condição imposta (por exemplo, todas as células maiores que 0 ) e atribui-se 1 para as que respeitarem tal condição.
} 
Com estas áreas determinadas, basta multiplicar para cada pólo os valores dos mapas de área de influência com os respectivos preços e somar os resultados de todos os pólos. Forma-se, assim, o mapa com os preços para toda a Amazônia.

A etapa de cálculo da receita líquida para cada célula utiliza estes mapas de preços que foram gerados na etapa anterior. Os valores dos mapas de preços de adubo e calcário são multiplicados pelas diferentes necessidades que cada tipo de solo demanda nas diversas regiões da Amazônia. Obtém-se assim os mapas com o gasto total de cada célula com estes insumos.

É importante salientar que os parâmetros utilizados neste cálculo foram obtidos através de pesquisa de campo e consulta a técnicos das regiões realizadas durante os meses de setembro e outubro de 1999. Os dados de custo de produção, produtividade esperada e demandas de fertilizantes e calcário foram retirados de planilhas de custo de produção que são elaboradas para projetos de financiamento de custeio da produção junto ao Banco do Brasil. Estes dados foram obtidos junto aos agrônomos de cada região que são os responsáveis por estes projetos. Apesar de estas planilhas de custo de produção não serem completas e, em alguns casos, poderem conter dados deturpados, esta foi a melhor forma de homogeneizar a coleta de dados para os custos de produção. Além disso, algumas regiões ainda não produzem soja e, portanto, não apresentam estes dados de custos, sendo necessária a extrapolação dos custos de regiões com características semelhantes de clima e solo. Para o caso de solos com poucos dados para uma determinada região, recorreu-se a técnicos que indicavam as diferenças em termos do uso de insumos, permitindo a elaboração de uma planilha simulada.

A planilha de custo apresentada ao Banco do Brasil, no entanto, não apresentaos custos de administração, armazenagem e secagem de grãos. Estes custos foram então obtidos através da média dos valores encontrados por FNP (2000) para os municípios produtores de soja na Amazônia Legal (o valor obtido foi $\mathrm{R} \$ 91,11$ / ha). Somados aos outros custos operacionais (coletado das planilhas de custo de produção obtidas em campo), ao custo de abertura e sistematização de área e aos custos de administração e pós-colheita, obtém-se o mapa de custo de produção por hectare para cada célula. 
O procedimento utilizado para esta segunda etapa dos cálculos está esquematizado na Figura 7.

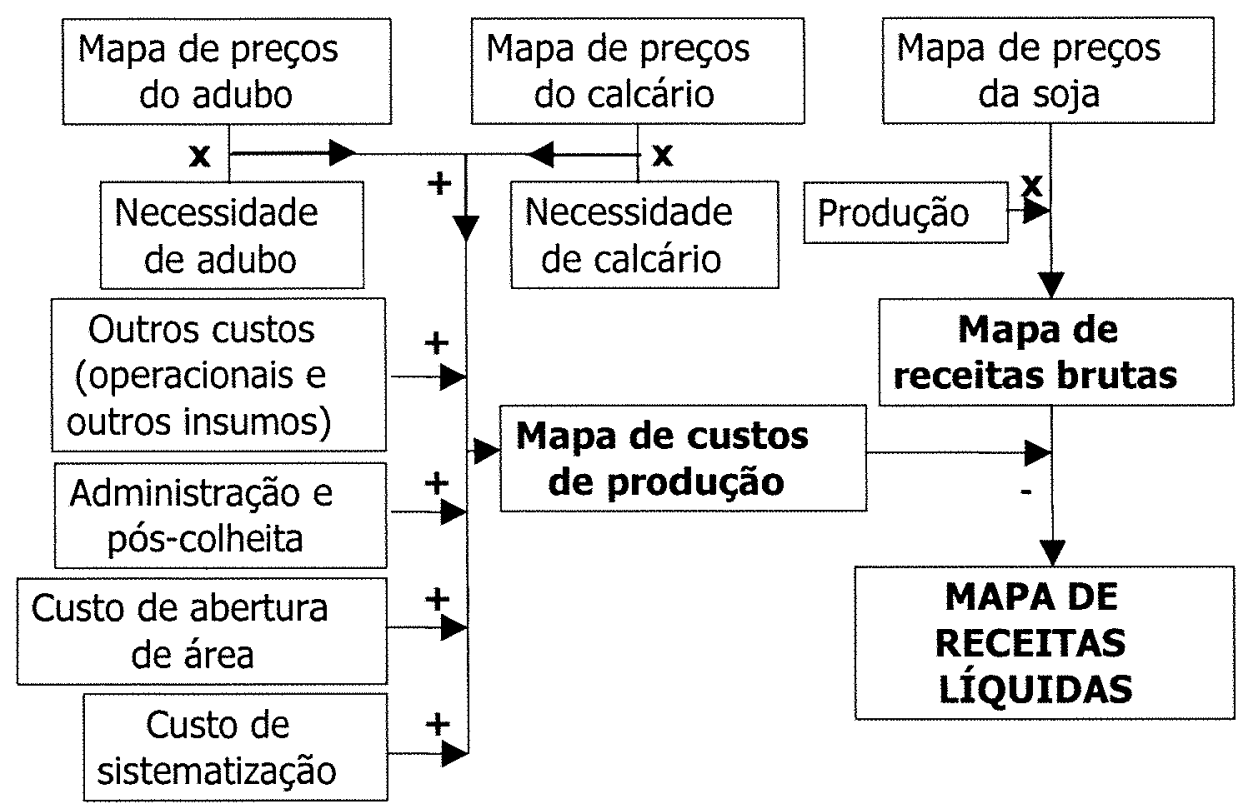

Figura 7. Rotina de cálculo simplificada para a confecção do mapa de receitas líquidas.

Finalmente, os preços da soja, multiplicados pela produtividade por hectare e por 35 ha e subtraído do mapa de custo de produção por hectare vezes 35 , gera o mapa de receita líquida da soja para toda a Amazônia. Estes mapas são multiplicados por 35 pois observouse, pelos dados do IBGE de área de grãos, comparada com a área total dos municípios para o ano de 1997, que a média de utilização da área de alguns importantes municípios agrícolas da Amazônia Legal representava 35\% da área total. Como cada célula representa 100 ha, assumiu-se que apenas $35 \%$ de cada célula poderia ser utilizada para a produção de soja. 
O mapa final de receitas líquidas, no entanto, não respeita todas as restrições do problema, pois considera que as vias têm capacidade ilimitada de transporte e todos os pólos demandantes de soja não têm limites operacionais. Assim, é necessário um método para se restringir as áreas de influência de alguns pólos e vias para que não se exceda os valores limites. Como o ArcView não é capaz de realizar este processo automaticamente, propõe-se um método para a solução deste problema, que corresponde à terceira etapa do procedimento de cálculo, que pode ser visualizada na Figura 8.

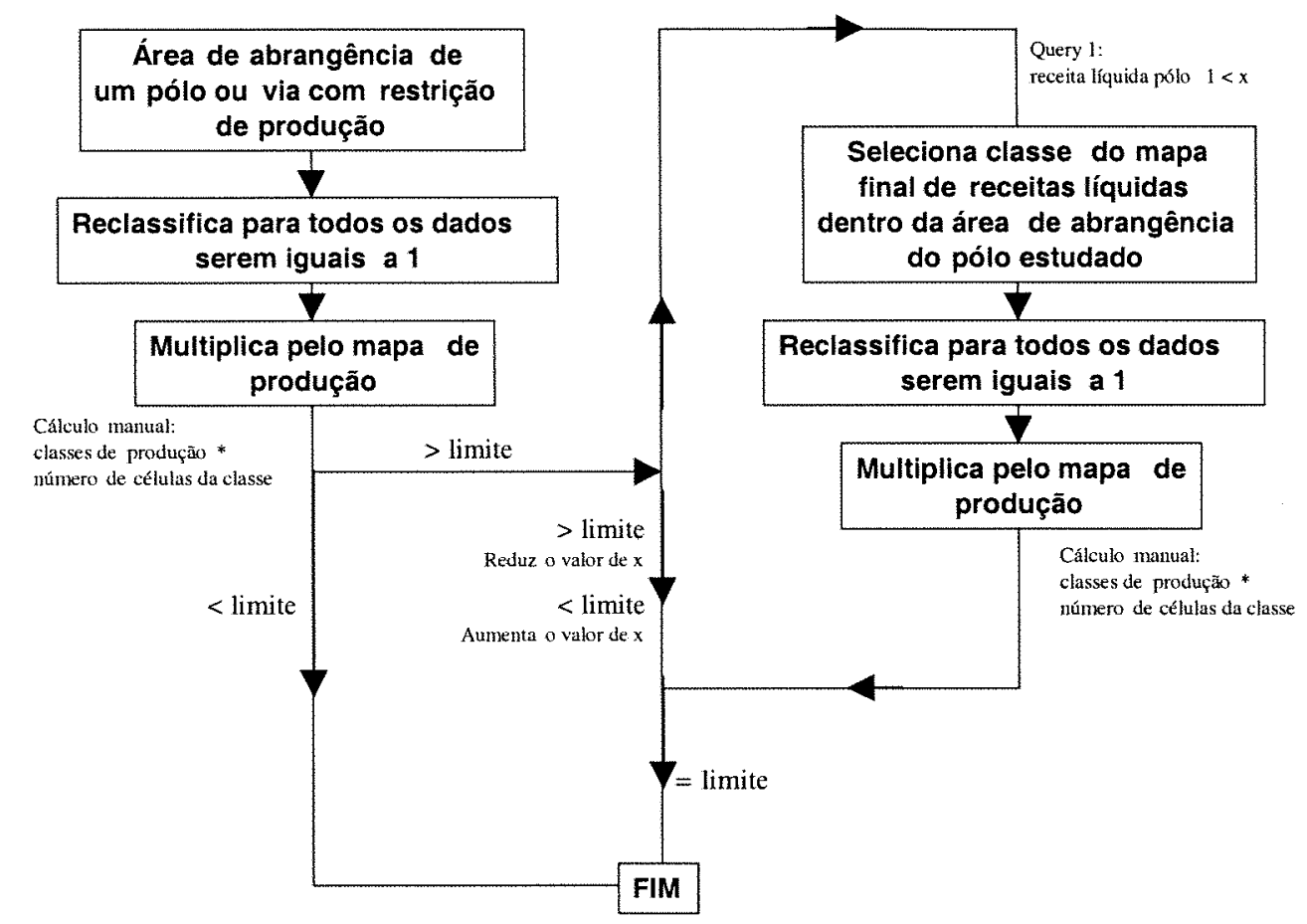

Figura 8. Rotina de cálculo para o cumprimento das restrições.

São utilizadas neste procedimento três ferramentas do programa: a "query", a "reclassify map" e a "map calculator". A primeira seleciona as regiões com receita líquida acima de um valor arbitrário, ou seja, mostra um mapa apenas com as rendas líquidas maiores que este valor atribuído. Com isso, seleciona-se as áreas que mais contribuem para a solução final, e que por isso, devem ter prioridade para utilizarem os modais mais baratos.

A segunda ferramenta reclassifica estas áreas selecionadas, atribuindo-lhes valores 1 e 0 , sendo 1 para as áreas selecionadas e 0 para o restante. Este é um passo intermediário que possibilita o terceiro passo deste procedimento. 
Por fim, a terceira ferramenta é utilizada para multiplicar os dados do mapa com 1 e 0 pelos respectivos valores de produção, obtendo-se assim o mapa com as produções das áreas selecionadas no primeiro passo. A informação mais importante deste mapa é a somatória das produções e não apenas a produção por célula, como aparece no mapa. Estes resultados podem ser visualizados na janela "Statistics" do "Legend Editor". O procedimento exige que o total produzido por esta região limitada (representado pela soma dos valores de produção do mapa) chegue o mais próximo possível do valor limite, sendo que somente neste caso o processo é finalizado. Caso isto não ocorra, reinicia-se o processo com outro valor de receita líquida.

Este método não chega ao valor ótimo, pois o mecanismo não permite que a produção de uma célula seja particionada. Isto faz com que as restrições não se cumpram por completo, ou seja, que o valor com o qual se interrompa o processo seja igual ao limite específico. Isto pode ser observado na Tabela 18, onde os valores com os quais se interrompeu o processo são diferentes dos limites estipulados. Se fosse possível se chegar ao limite, os resultados seriam alterados, apesar de não tão significativamente. São apresentados também na mesma Tabela 18 os valores de receita líquida mínima que permitiram se chegar a este valor de produção. Estes valores são os mais próximos das restrições e portanto, dentro das limitações do software utilizado, são os resultados mais próximos do resultado ótimo.

Tabela 18. Valores obtidos no processo de incorporação das restrições aos resultados

\begin{tabular}{lccc}
\hline \multicolumn{1}{c}{ Corredor } & $\begin{array}{c}\text { Limite de carga } \\
(\mathbf{t} / \mathbf{a n o})\end{array}$ & $\begin{array}{c}\text { Limite obtido } \\
(\mathbf{t} / \mathbf{a n o})\end{array}$ & $\begin{array}{c}\text { Receita líquida } \\
\text { mínima da área de } \\
\text { influência } \\
(\mathbf{R} \mathbf{~ / 3 5} \text { ha })\end{array}$ \\
\hline $\begin{array}{l}\text { Rio Tocantins (PA) } \\
\text { acima de Marabá }\end{array}$ & 1.000 .000 & 999.843 & 9.178 \\
Rio Tocantins (TO) & 1.000 .000 & 1.000 .469 & 11.173 \\
Rio Araguaia & 1.000 .000 & 1.000 .048 & 13.182 \\
$\begin{array}{l}\text { Rios Juruena, Teles } \\
\text { Pirres e Tapajós }\end{array}$ & 1.000 .000 & 1.000 .309 & 18.410 \\
Rio Madeira & 1.300 .000 & 1.299 .298 & 17.458 \\
\hline
\end{tabular}


Tabela 18. Valores obtidos no processo de incorporação das restrições aos resultados

\section{Receita líquida}

Corredor

\begin{tabular}{|c|c|c|c|}
\hline 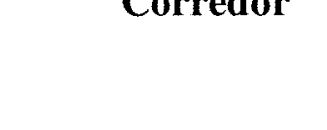 & $(t /$ ano $)$ & $(\mathrm{t} /$ ano $)$ & $\begin{array}{c}\text { influência } \\
\text { ( } \mathbf{R} \$ \text { / } 35 \text { ha ) }\end{array}$ \\
\hline Ferrovia Carajás & 10.000 .000 & 10.000 .672 & 8.685 \\
\hline Ferrovia Jari & 20.000 .000 & Não restritivo & - \\
\hline Ferronorte & 20.000 .000 & 19.999 .913 & 10.028 \\
\hline $\begin{array}{l}\text { Agroindústria de } \\
\text { Vilhena }\end{array}$ & 60.000 & 60.030 & 20.636 \\
\hline
\end{tabular}

Fonte: dados da pesquisa

Constata-se assim que o método utilizado é bastante trabalhoso e demanda uma grande quantidade de tempo. A confecção de cada mapa de custo de transporte consumiu em média 1 hora e meia do trabalho de uma pessoa. As operações básicas (adição, subtração, multiplicação e divisão) entre mapas consomem cerca de 2 minutos cada. $\mathrm{O}$ cálculo das restrições utiliza, em média, 40 minutos para se chegar ao valor limite de cada pólo (este processo é necessariamente manual). No total, foram necessários 45 dias de trabalho de uma pessoa para todos os cálculos do cenário base, incluindo o tempo perdido pela inexperiência com os mecanismos do software.

Além disso, os mapas gerados ocupam uma grande quantidade de espaço em disco no computador, sendo que cada mapa de preços, custos ou receitas exigiu cerca de $34 \mathrm{MB}$ de espaço no disco rígido. Aconselha-se utilizar este método em computadores com discos rígidos superiores a $4 \mathrm{~GB}$ e com facilidade para a gravação dos dados em CDs. 


\section{RESULTADOS}

Os resultados obtidos por este trabalho são apresentados em mapas e tabelas. As análises serão realizadas considerando a Amazônia como um todo e separada pelos seus estados, pelos tipos de vegetação. Além disso, por se tratar de uma situação futura, algumas simulações foram realizadas a partir da variação de parâmetros que podem, eventualmente, se alterar ao longo do tempo, como valores de preços e de custos.

\subsection{Receita líquida da soja para a Amazônia}

Para a elaboração das análises foi considerado um cenário base, sobre o qual algumas simulações foram realizadas. O detalhamento das pressuposições e informações utilizadas no cenário base está apresentado no Anexo 3. Este cenário considera todas as alternativas de transporte planejadas para a Amazônia Legal já finalizadas, com exceção do asfaltamento da BR 163. Além disso, não considera limitações de clima e relevo; permite que apenas 35\% da área de cada célula seja utilizada com a soja; os dados de preços, custos, fretes e produtividades são baseados na situação observada em 1999.

As receitas líquidas por hectare obtidas com os dados deste cenário podem ser visualizadas na Figura 9, estando também sistematizadas nas Tabelas 19, 20 e 21 e na Figura 10. 


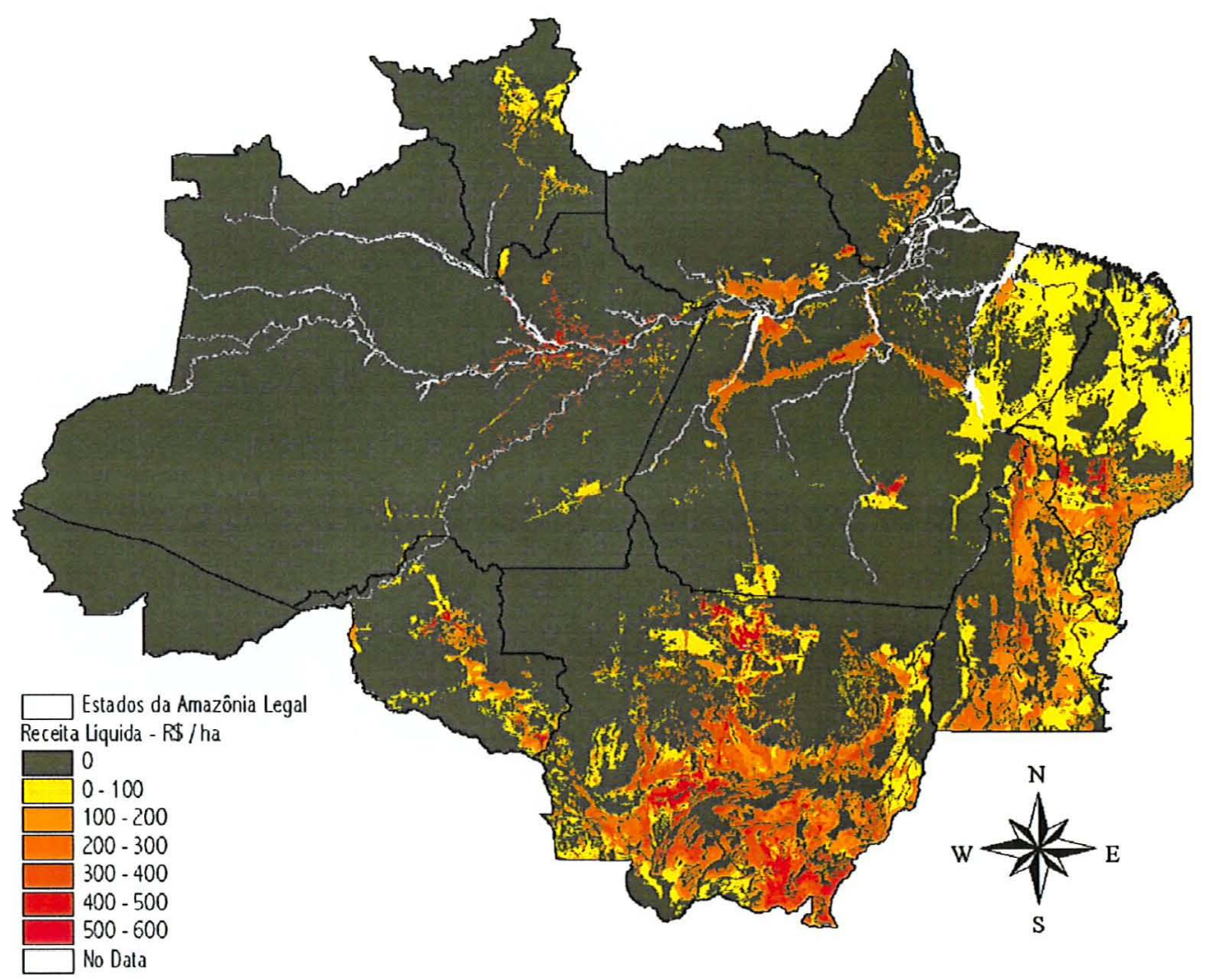

Figura 9. Receita líquida obtida com a soja na Amazônia Legal, cenário base, em R $\$$ / ha

A Figura 9 apresenta a receita líquida obtida com a soja plantada na Amazônia Legal. Observa-se que as regiões mais interessantes para esta cultura (representadas na figura pelas cores laranja escuro e vermelho) estão concentradas principalmente nas áreas de cerrado (partes do Mato Grosso, Rondônia, Tocantins e Maranhão) e já desmatadas. Estas regiões, apesar de estarem mais distantes dos portos e obterem preços mais baixos, congregam vários outros fatores que estimulam a produção de soja nestas localidades, como: infra-estrutura de transportes mais desenvolvida, produtividades altas, áreas já abertas para a agricultura ou com custos baixos para a abertura e menores custos de produção.

No entanto, algumas outras áreas já desmatadas, que se situam próximas a um porto, e que portanto obtêm preços mais altos, também apresentam receitas altas, como é o caso de Itacoatiara (AM), Santarém (PA) e Santana (AP). Nestas regiões, por sinal, situam-se as 
localidades com maiores receitas líquidas, pois congregam além dos preços altos, produtividades também altas. Regiões com produtividades bastante altas também se destacam no mapa, como São Félix do Xingú, onde se observam manchas de Terra Roxa Estruturada, com altas produtividades e baixa utilização de insumos.

As demais regiões são penalizadas pela deficiência na infra-estrutura de transportes, envolvendo maiores distâncias até os portos, além da presença de florestas (que apresentam um alto custo de desmatamento) ou pelas produtividades menores, o que implica receitas líquidas menores ou até negativas.

As informações ilustradas na Figura 9 podem ser visualizadas de uma maneira mais sintética na Figura 10.

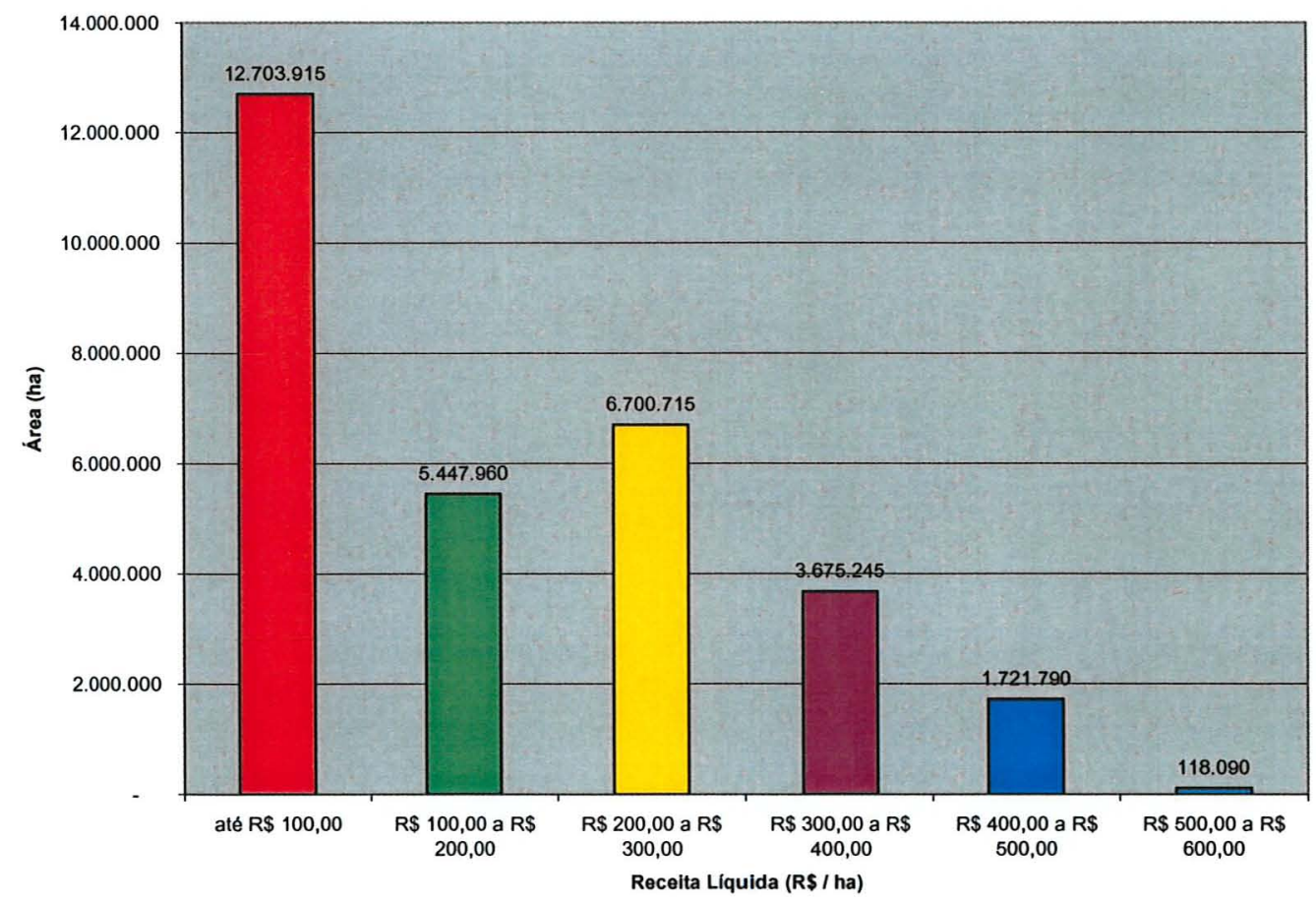

Figura 10. Área da Amazônia Legal com viabilidade para o plantio de soja, dividida em faixas de receita líquida.

Nota-se que a maior parte das áreas está concentrada nas menores faixas de receita líquida. As três primeiras faixas, que congregam receitas líquidas que vão até $R \$ 300,00$ / ha, ocupam $81,84 \%$ da área viável para a soja e somente a primeira (até $\mathrm{R} \$ 100,00$ / ha) ocupa $41,83 \%$. 
É interessante notar que os valores obtidos em algumas regiões são extremamente altos comparados aos ganhos obtidos em outras regiões do país. Isto acontece pois tanto os custos como os preços dependem da proximidade dos portos. Assim, nos arredores de cidades portuárias, conjuga-se baixo custo com alta receita e os valores de receita líquida tornam-se bastante altos. Assim, por ser um modelo hipotético, a análise principal deve ser feita em termos relativos e não absolutos, pois estes valores podem vir a se tornar bastante diferentes quando da efetiva observação da realidade.

\subsection{Produção e área plantada por estado}

Nas Tabelas 19, 20 e 21 são apresentados os dados de produção e área plantada discriminados por estado, por tipo de vegetação e por demandante (corredor de exportação ou agroindústria).

Tabela 19. Participação de cada estado da Amazônia Legal na produção de soja e na área plantada com soja

\begin{tabular}{lcccc}
\hline \multicolumn{1}{c}{ Estado } & $\begin{array}{c}\text { Produção } \\
\text { (t) }\end{array}$ & $\mathbf{\%}$ & $\begin{array}{l}\text { Área } \\
\text { (ha) }\end{array}$ & $\%$ \\
\hline Mato Grosso & 36.612 .789 & $43 \%$ & 11.994 .430 & $39 \%$ \\
Pará & 14.175 .147 & $17 \%$ & 5.340 .405 & $18 \%$ \\
Maranhão & 14.171 .673 & $17 \%$ & 5.286 .085 & $17 \%$ \\
Tocantins & 12.075 .482 & $14 \%$ & 4.674 .180 & $15 \%$ \\
Rondônia & 3.812 .185 & $4 \%$ & 1.261 .400 & $4 \%$ \\
Amazonas & 2.234 .088 & $3 \%$ & 832.895 & $3 \%$ \\
Roraima & 1.433 .042 & $2 \%$ & 596.015 & $2 \%$ \\
Amapá & 1.026 .950 & $1 \%$ & 382.375 & $1 \%$ \\
Acre & - & $0 \%$ & - & $0 \%$ \\
\hline AMAZÔNIA & 85.541 .356 & $100 \%$ & 30.367 .785 & $100 \%$ \\
\hline
\end{tabular}

Fonte: dados da pesquisa

Os dados da Tabela 19 mostram que, segundo os parâmetros assumidos por este modelo, a Amazônia poderá estar produzindo mais de 85,5 milhões de toneladas de soja, ocupando mais de 30,3 milhões de hectares. Para esses cálculos, foi considerado que a soja ocupará apenas $35 \%$ da área de cada célula de $1 \mathrm{~km}^{2}$, o que representa 170.892 .050 ha de área agrícola para a Amazônia. Assim, as restrições do modelo limitam a área com soja em apenas $17,77 \%$ da área agrícola considerada. Se considerar-se a área total da Amazônia (cada célula correspondendo a $1 \mathrm{~km}^{2}$ ), a soja potencialmente ocupa $6,22 \%$ da área. 
Quanto à distribuição da produção entre os estados, com exceção do Pará, os estados que predominarão como produtores de soja na Amazônia Legal vão ser os que já têm uma relativa importância atualmente.

O Mato Grosso, que é o segundo estado maior produtor de soja do país, tende a manter sua hegemonia na região, mas com participação relativa menor que a atual. Esta aparente redução na importância se dá, na verdade, pelo maior crescimento dos outros estados devido à existência de mais áreas que ainda podem ser incorporadas à agricultura. Em termos absolutos, no entanto, a tendência é o Mato Grosso aumentar tanto sua produção como a sua área em relação ao observado atualmente, sendo este crescimento direcionado para o norte do estado.

Os estados do Maranhão e Tocantins, que atualmente têm taxas de crescimento bastante elevadas e pólos graneleiros importantes (Balsas e Pedro Afonso, respectivamente) aumentam sua participação relativa e ocupam uma grande parte de suas áreas com grãos. Este crescimento é motivado pela importante infra-estrutura de transportes presente nestes estados, como as ferrovias Norte-Sul e Carajás, as hidrovias do Tocantins e Araguaia e uma ampla malha rodoviária asfaltada, tendo como eixo principal a rodovia BR 010/153 (Belém - Brasília). Esta multimodalidade, aliada à proximidade com o porto de Itaqui, em São Luís (MA), contribui para a viabilidade econômica da soja na maior parte destes dois estados. No entanto, vale ressaltar que algumas áreas, principalmente no Tocantins, apresentam limitações de solo e clima, existindo regiões quase desérticas, como o Jalapão. Isto deve limitar a área viável destes estados e reduzir sua participação no total (algumas considerações sobre pluviosidade serão feitas na seção 4.5).

Se desconsiderar-se todos os solos de Areia Quartzosa da região amazônica, solos em geral com alto risco de perdas ou até improdutivos, teremos uma redução de 4.810 .470 ha, o que correspode a $15,84 \%$ da área obtida na primeira solução deste modelo (vide Tabela 39, na seção 4.12).

Além disso, o volume total transportado até São Luís (MA) é superior ao observado apenas na região apresentada no mapa, pois regiões como o sul do Piauí e oeste da Bahia, 
onde já existem pólos graneleiros formados ou em formação, não estão apresentados nesta solução, mas poderão ter participação importante no fluxo de soja por este corredor.

No entanto, o estado com maior crescimento, de acordo com este cenário, é o Pará, tendo dois pólos distintos de crescimento: o Sul / Sudeste do estado (sendo a expansão das áreas do Maranhão e Tocantins) e o Oeste, motivado pelo advento da hidrovia do Tapajós e do Terminal Graneleiro de Santarém. Pela Figura 8 podemos observar que o primeiro pólo é claramente mais importante que o segundo devido à melhor infra-estrutura de transportes observada nesta região (a região sul e sudeste do estado concentra as duas rodovias mais importantes do estado em termos de volume de carga - a Belém-Brasília e a PA-150 - além da hidrovia do Tocantins e da ferrovia Carajás).

O pólo do oeste do Pará se concentra ao longo das rodovias (principalmente a Transamazônica e a BR 163, consideradas como não asfaltadas neste cenário) e no entorno de Santarém. As regiões ao longo das rodovias são ainda pouco desenvolvidas e com uma cobertura florestal bastante importante (nesta região se concentram as principais regiões com mogno na Amazônia). Estes fatos contribuem para o aumento dos custos de produção e, por isso, as áreas com potencial para a produção são reduzidas.

Já a região do entorno de Santarém apresenta duas grandes vantagens: i) a proximidade do porto de Santarém torna o preço pago pela soja na região bastante atrativo, além de reduzir os preços dos insumos e; ii) as áreas da margem esquerda do Amazonas (região de Alenquer e Monte Alegre) apresentam solos excelentes e, consequentemente, produtividades altas, aumentando a atratividade desta região. No entanto, para estas áreas ainda existem dúvidas quanto à viabilidade técnica de produção, principalmente devido ao clima úmido, que deve favorecer o aumento de incidência de doenças fúngicas (vide seção $4.5)$.

Além das regiões Sul/Sudeste e Oeste, uma outra região do Pará, às margens do rio Xingú, também aparece com importância neste cenário. Esta região, apesar de isolada, apresenta duas características importantes que a viabilizam: i) solos excelentes e ii) acesso por terra à rodovia PA 150, que dá acesso à hidrovia do Tocantins. Estes dois fatores 
ajudam a explicar o fato de existir atualmente uma colônia de sulistas nesta região, produzindo produtos agrícolas para Belém.

Os estados de Rondônia e Amazonas apresentam participações mais modestas devido às limitações de transporte. As principais regiões produtoras do estado do Amazonas estão situadas nas proximidades de Manaus e Itacoatiara, onde se concentra a melhor infra-estrutura de transportes do estado, inclusive com um terminal graneleiro exportador em Itacoatiara. Algumas áreas nas margens do rio Madeira também apresentam viabilidade econômica segundo este modelo, mas são limitadas pela capacidade de transporte da hidrovia referente a este rio, que neste cenário é de 1,3 milhão de toneladas / ano. Um outro pólo significativo está situado ao longo da Transamazônica, nas proximidades de Apuí (AM). Esta região, apesar de ter difícil acesso por terra (este trecho da Transamazônica é intransitável no período das chuvas), vem apresentando nos dias de hoje um crescimento da área agrícola, principalmente com o café. Algumas experiências estão sendo feitas com milho, arroz e soja, mas a dificuldade de acesso prejudica um projeto mais estruturado como o que vem ocorrendo em Humaitá (AM). Certamente, a principal vantagem desta região é a sua a boa qualidade dos solos, que permite uma alta produtividade.

As áreas que aparecem na solução correspondem principalmente às áreas já desmatadas, o que demonstra a importância dos custos de abertura de área para a viabilidade econômica da soja. Como os dados utilizados de desmatamento são de 1991, é de se esperar que outras áreas também já desmatadas, a partir desta data, também entrem na solução, principalmente sabendo que os desmatamentos são feitos sempre acompanhando o percurso das estradas, onde também os custos de transporte são mais baixos.

Rondônia, por outro lado, sofre menos a influência da hidrovia do Madeira, principalmente pela limitação desta via, e transporta seus produtos para basicamente dois destinos: Vilhena e Santarém. No primeiro caso, a existência de uma pequena esmagadora de soja que paga preços bem acima do mercado é o grande estímulo. No entanto, a capacidade de esmagamento desta indústria é bastante reduzida (600 t / dia). Assim, Santarém torna-se o principal destino da soja de Rondônia. Este percurso, feito através de rodovias, apesar de parecer ilógico, tem respaldo. Neste cenário considerou-se Itacoatiara 
inacessível por terra, ficando como opções Santarém e Paranaguá. Como o limite da Ferronorte já havia sido atingido com as regiões do Mato Grosso, o percurso rodoviário até Santarém se tornou mais barato que o percurso até Paranaguá com o mesmo modal. No entanto, se considerarmos a viabilidade de acesso rodoviário até Itacoatiara (através da rodovia Porto Velho - Manaus), este porto certamente receberia a soja de Rondônia.

Roraima e Amapá são dois estados que têm pouca participação devido ao grande número de áreas protegidas e de áreas inaptas à agricultura. Assim, os valores apresentados são os máximos possíveis, mesmo se desconsiderarmos as restrições de carga das vias. Por fim, segundo este modelo, o Acre está fora do mapa de produção da soja na Amazônia Legal, pois apresenta ainda muitas áreas florestadas, produtividades baixas e uma distância significativa para a hidrovia do Madeira.

\subsection{Produção e área plantada por tipo de vegetação anterior à soja}

As áreas onde a soja tem potencial, segundo os dados do modelo, são principalmente regiões já desmatadas $(59 \%)$ ou de cerrados $(34 \%)$, conforme pode-se observar na Tabela 20. Este vem sendo o processo normal de ocupação da fronteira agrícola, com a soja ocupando preferencialmente os cerrados (de menores custos de abertura) e as antigas áreas de pastagens. No entanto, existe $4 \%$ da área onde a soja teria um efeito direto no desmatamento de floresta Amazônica.

Tabela 20. Tipo de vegetação encontrada nas regiões onde a soja é viável economicamente

\begin{tabular}{|c|c|c|c|c|}
\hline Vegetação & $\begin{array}{l}\text { Produção } \\
(\mathbf{t})\end{array}$ & $\%$ & $\begin{array}{l}\text { Área } \\
\text { (ha ) }\end{array}$ & $\%$ \\
\hline Antrópicas & 50.659 .349 & $59 \%$ & 17.994 .305 & $59 \%$ \\
\hline Cerrado & 31.364 .331 & $37 \%$ & 11.205 .985 & $37 \%$ \\
\hline Floresta & 3.517 .864 & $4 \%$ & 1.167 .565 & $4 \%$ \\
\hline AMAZÔNIA & 85.541 .544 & $100 \%$ & 30.367 .855 & $100 \%$ \\
\hline
\end{tabular}

Fonte: dados da pesquisa

Os dados da Tabela 20 podem ser visualizados espacialmente na Figura 11. 


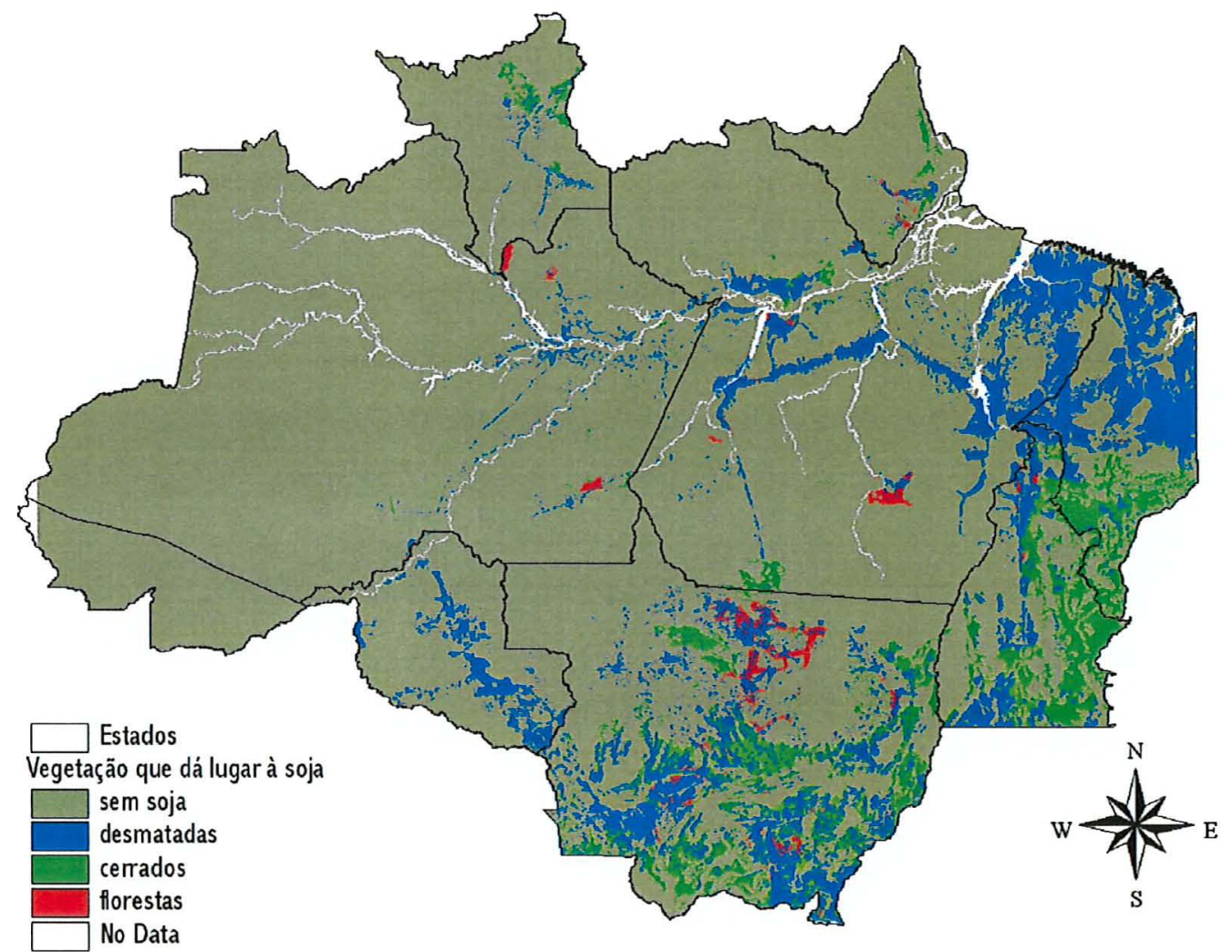

Figura 11. Vegetação original das áreas com potencial para a produção de soja

As áreas onde o desmatamento já ocorreu (representadas em azul na Figura 11) são resultantes da criação de bovinos ou assentamentos rurais, tendo sido motivados principalmente pela construção de rodovias nas décadas de 70 e 80 . Com isso, estas regiões apresentam uma tendência muito maior de recebimento de soja frente às áreas que necessitam de desmatamento, devido aos altos custos de abertura de área destas outras regiões.

Quanto às áreas de cerrado (em verde na Figura 11), o impacto da soja deve ser acentuado. No Maranhão e no Tocantins o potencial de conversão é maior, principalmente devido à melhor infra-estrutura de transportes que dá acesso a estas áreas. O Mato Grosso também deve incorporar uma grande área de cerrados ao processo produtivo, também devido à infra-estrutura já existente neste estado. Outros estados como Roraima, Amapá e Pará também têm o potencial de converter áreas de cerrado para o cultivo agrícola, mas em menor escala que estes três primeiros. 
No entanto, para as áreas de floresta Amazônica, as principais áreas onde a soja age diretamente sobre o desmatamento (que são apenas $4 \%$ do total) estão fortemente relacionadas com as hidrovias (neste caso, dos rios Juruena-Teles Pires-Tapajós, Tocantins e Negro) ou com portos (Santana e Santarém). No primeiro caso, o custo baixo de frete possibilita insumos mais baratos e um preço para a soja mais alto, o que compensa os altos custos de abertura de área. No segundo caso, os preços pagos pela soja são os mais altos, o que compensa também o custo de abertura.

É importante ressaltar, no entanto, que, apesar de contribuir com o desmatamento de apenas $4 \%$ da área, a expansão da área agrícola tem um importante papel indireto no desmatamento, na medida em que os pecuaristas, quando dão lugar à agricultura, tendem a buscar novas áreas, normalmente florestadas, para plantar suas pastagens.

Além disso, a produção de soja nas áreas mais úmidas da Amazônia ainda é tecnicamente questionável, pois não existem dados conclusivos a respeito de sua viabilidade de produção. Acredita-se que a alta umidade possa aumentar a ocorrência de doenças e isto inviabilizaria a produção tanto economicamente como tecnicamente. Este cenário considera que a soja não terá maiores problemas em se estabelecer nestas regiões mais úmidas, sendo que as variações do clima na produção serão consideradas na seção 4.5 (os dados de produtividade, por terem sido coletados no campo, podem incorporar algumas variações históricas causadas pelas características climáticas das diversas regiões).

Outra restrição nos dados é o mapa de desmatamento utilizado. Apesar de ser o último disponível no formato apropriado para o ArcView, está bastante defasado (sabe-se que a segunda metade da década de 90 foi bastante intensa em termos de abertura de florestas e cerrados). Assim, muitas áreas que não são viáveis neste mapa podem, na verdade, já estarem desmatadas e assim tornarem-se rentáveis. Para se ter uma idéia do impacto do desmatamento nos resultados deste modelo, se não considerarmos as áreas desmatadas, $34,07 \%$ (10.347.435 ha) da área com soja deste cenário estariam fora da solução.

No relatório de 2000 do INPE (Instituto Nacional de Pesquisas Espaciais) sobre o desmatamento na Amazônia (INPE, 2000), pode-se ter uma idéia de como este 
desmatamento evoluiu durante este tempo, podendo-se, assim, ter uma idéia de onde a soja pode ter viabilidade. Na Tabela 21 estão apresentados os dados relativos ao aumento da área desmatada entre 1991 e 1998.

\begin{tabular}{lc}
$\begin{array}{c}\text { Tabela 21. Variação na área desmatada entre } \\
\text { 1991 e 1998 separado por estados da } \\
\text { Amazônia Legal, em ha. }\end{array}$ \\
\hline \multicolumn{2}{c}{$1991-1998$} \\
\hline Mato Grosso & 4.530 .800 \\
Pará & 4.037 .200 \\
Rondônia & 1.867 .500 \\
Maranhão & 649.000 \\
Amazonas & 566.600 \\
Acre & 401.400 \\
Tocantins & 300.400 \\
Roraima & 159.100 \\
Amapá & 26.200 \\
\hline AMAZÔNIA & 12.538 .200 \\
\hline Fonte: INPE (2000)
\end{tabular}

Nota-se que, no total, a utilização de um mapa de 1991 deixa de incluir cerca de 12,5 milhões de ha, supondo que estas áreas desmatadas entrariam na solução do problema. Os estados que mais desmataram áreas durante estes anos foram o Mato Grosso e o Pará, seguidos por Rondônia. Os demais estados apresentam áreas desmatadas bem menores, mas ainda significativas. Isto demonstra que o desmatamento continua o seu caminho de expansão do sul para o norte, avançando lentamente com a melhoria nas condições de infraestrutura das regiões de fronteira.

O desmatamento por tipo de vegetação alterada pode ser visualizado na Figura 12.

Nota-se que as vegetações mais afetadas são as florestas umbrófilas e a vegetação de transição, ou seja, exatamente as mesmas vegetações encontradas no Norte do Mato Grosso, Sudoeste do Pará, Rondônia, Maranhão e Amazonas. Vegetação de transição representa inúmeros tipos de vegetação, como o cerradão do Norte de Mato Grosso e Rondônia e a Mata de Cocais do Maranhão. Assim, nota-se que o desmatamento, atualmente está sendo feito sobre vegetações mais densas e que teriam um desincentivo econômico para a entrada da cultura da soja. No entanto, como trata-se de áreas já 
desmatadas, passam a ter interesse direto para o plantio de soja, principalmente se estiverem bem localizadas.

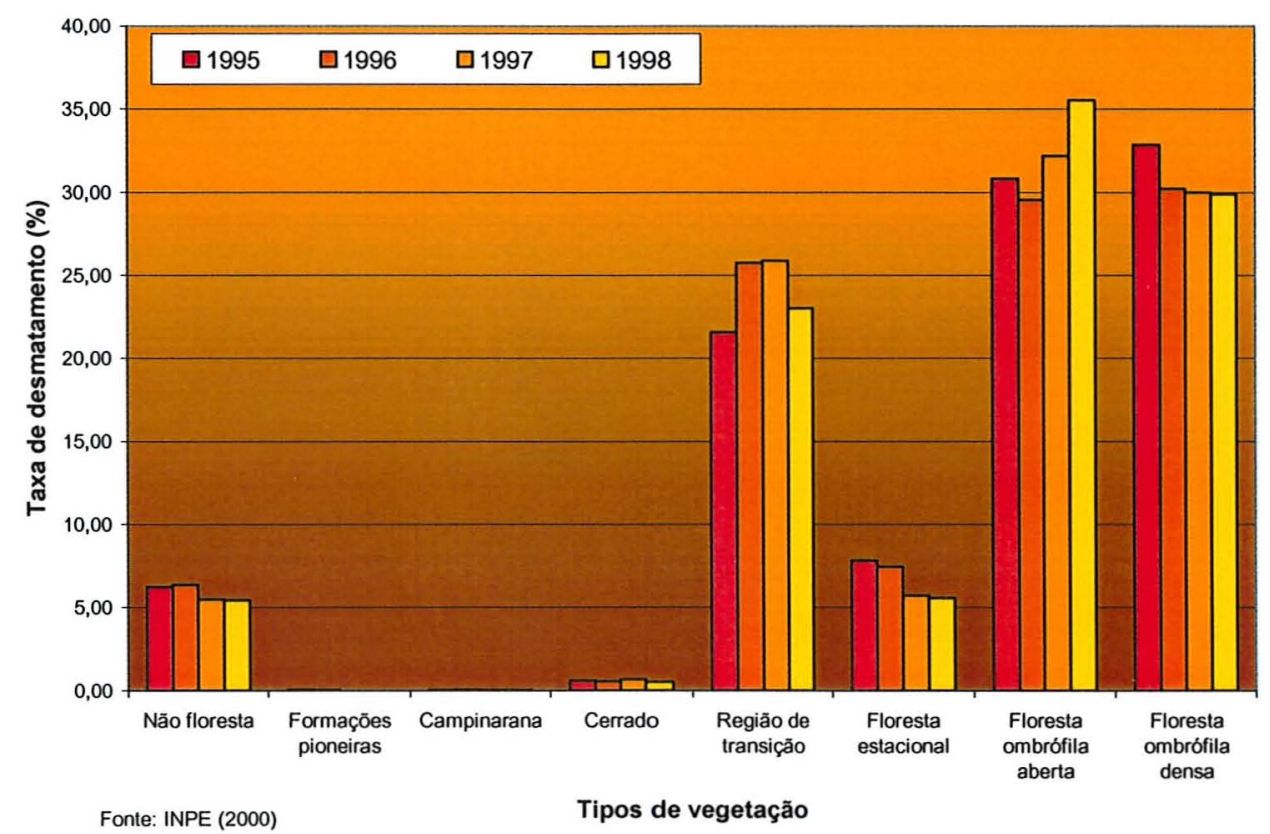

Figura 12. Taxa de desmatamento anual por tipo de vegetação entre 1995 e 1998, INPE (2000).

Na Figura 13 podemos identificar as áreas onde os principais desmatamentos do ano de 1998 ocorreram (pretos no mapa). 


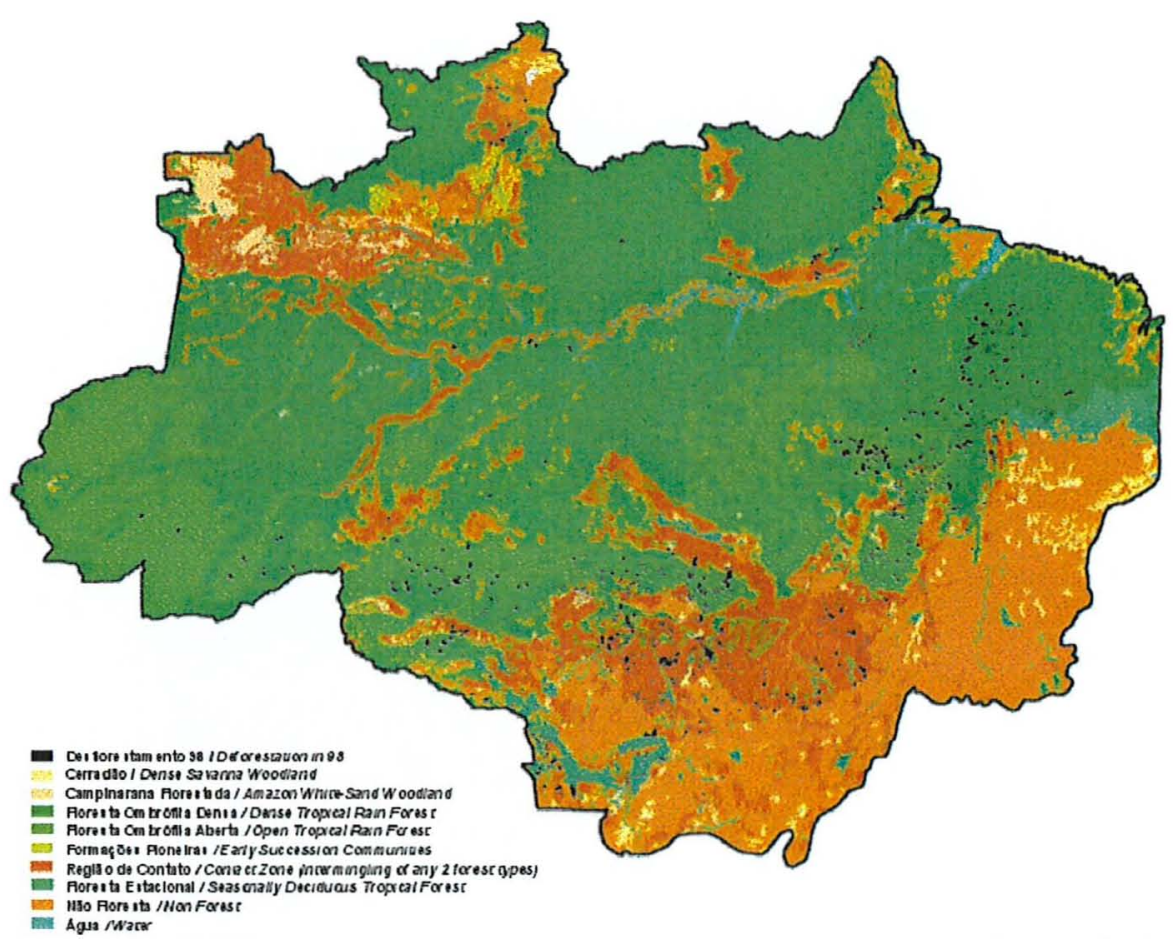

Figura 13. Mapa com os desmatamentos observados no ano de 1998, INPE (2000)

Nota-se que as áreas de desmatamento estão em regiões de alto interesse para a soja, segundo o cenário base. Estes desmatamentos se concentram no leste do Pará, no norte do Mato Grosso e em Rondônia, formando praticamente uma faixa contínua. Estas regiões terão acesso facilitado aos novos corredores de transporte, o que deve estimular muito a introdução de soja nestas áreas.

Assim, podemos afirmar que grande parte destes 12,5 milhões de ha de desmatamento após 1991 (que somam-se a mais 1.692 .600 ha desmatados em 1999, segundo o INPE) deve ser alvo da agricultura comercial após a conclusão dos projetos de infra-estrutura de transportes previstos. Isto reforça a idéia de que a soja terá um efeito indireto no desmatamento da Amazônia muito mais importante do que o seu efeito direto.

\subsection{Produção e área plantada por demandante}

A Tabela 22 apresenta o volume de soja transportado para cada destino final considerado neste trabalho. 
Tabela 22. Quantidade de soja transportada e área de influência de cada porto ou agroindústria da Amazônia Legal.

\begin{tabular}{lrrrr}
\hline \multicolumn{1}{c}{ Corredores } & \multicolumn{1}{c}{ Produção } & \multicolumn{1}{c}{$\%$} & \multicolumn{1}{c}{ Área } & \multicolumn{1}{c}{$\%$} \\
\hline São Luís (MA) & 31.905 .285 & $37 \%$ & 12.013 .645 & $39 \%$ \\
Paranaguá (PR) & 28.672 .125 & $33 \%$ & 9.270 .555 & $30 \%$ \\
Santarém (PA) & 13.206 .092 & $15 \%$ & 4.681 .285 & $15 \%$ \\
Vila do Conde (PA) & 7.699 .369 & $9 \%$ & 2.825 .970 & $9 \%$ \\
Caracas (Venezuela) & 1.655 .462 & $2 \%$ & 679.490 & $2 \%$ \\
Itacoatiara (AM) & 1.299 .298 & $2 \%$ & 475.055 & $2 \%$ \\
Santana (AP) & 1.292 .092 & $2 \%$ & 479.010 & $2 \%$ \\
Vilhena (RO) & 60.030 & $0 \%$ & 18.270 & $0 \%$ \\
\hline AMAZÔNIA & 85.789 .753 & $100 \%$ & 30.443 .280 & $100 \%$ \\
\hline
\end{tabular}

Fonte: dados da pesquisa

Nota-se que, segundo o modelo proposto, o principal corredor da Amazônia será o que leva ao porto de Itaqui em São Luís (MA). Como já foi citado anteriormente, este corredor é o mais completo em termos de multimodalidade, sendo constituído por duas hidrovias, duas ferrovias e uma ampla malha rodoviária asfaltada. Esta estrutura viabiliza a produção mesmo em áreas com baixa produtividade, pois os custos de produção são menores (decorrentes de menores preços dos insumos) e os preços finais mais altos. Além disso, a vegetação predominante é o cerrado, de abertura mais fácil, ou a agricultura. Este corredor também contribui bastante para a inserção de novas áreas no processo produtivo, principalmente no Pará e Tocantins, devendo também receber soja de outras regiões fora da área da Amazônia Legal, como o sul do Piauí.

Paranaguá continuará a ser um importante destino para a soja do Centro-Oeste, principalmente motivado pela conclusão das obras do trecho da Ferronorte até Cuiabá. Este corredor é favorecido pelo fato de não necessitar de transbordo até Paranaguá e de se iniciar próximo às áreas de maior produção do Mato Grosso. No entanto, as áreas que transportam sua soja por este corredor são, em sua maioria, as que já estão em produção atualmente, não incorporando novas áreas no processo produtivo. Além disso, muitas das áreas da região sul do Mato Grosso (principal área influenciada por este corredor) já estão convertendo as suas produções de soja para outras mais rentáveis, como o algodão, por exemplo. Este corredor, portanto, apesar de ser o segundo mais importante em termos de volume, muito pouco vai contribuir para a expansão da soja na Amazônia Legal. 
Estes dois corredores têm como característica o fato de ambos terem como eixo central as ferrovias. Isto explica em parte o porquê de serem os que tem maiores áreas de influência, pois as ferrovias, neste cenário, têm uma capacidade de transporte muito maior que as hidrovias (10 milhões de toneladas / ano contra cerca de 1 milhão de toneladas / ano, respectivamente).

Além disso, explica também a diferença para os corredores de Santarém e, principalmente, para Itacoatiara. Neste primeiro caso, a hidrovia do Tapajós contribui apenas com 1 milhão de toneladas, sendo o restante transportado pela rodovia BR 163. Esta rodovia permite que a soja do norte do Mato Grosso seja escoada para o porto de Santarém, contribuindo para os resultados deste cenário. O corredor que leva a Santarém será, segundo os dados deste cenário, o que mais vai contribuir para a abertura de novas áreas para a agricultura, principalmente no norte e noroeste do Mato Grosso e sudoeste do Pará.

Já a hidrovia do Madeira transporta apenas 1,3 milhão de toneladas neste cenário, $\mathrm{o}$ que limitou tremendamente a área de influência deste corredor. Como não há acesso rodoviário viável ao porto de Itacoatiara, este corredor fica limitado apenas à hidrovia.

Os demais corredores (Vila do Conde, Santana e Caracas) escoam produções menores pelo fato das suas respectivas regiões de influência não serem importantes para a produção de soja, principalmente por terem difícil acesso ou pouca vocação para a produção de grãos.

Por fim, a agroindústria de Vilhena também tem sua área de influência limitada pela sua capacidade operacional. Foi considerada neste caso a capacidade instalada de $3.000 \mathrm{t} /$ dia, conforme observada em campo. As agroindústrias de Cuiabá e Rondonópolis não apareceram na solução pois seus preços eram menores que os de Paranaguá. Isto tem sentido, pois os preços atuais são formados com base no preço de Paranaguá e considerando o frete exclusivamente rodoviário. Neste trabalho, considerou-se o transporte deste corredor como sendo feito exclusivamente por ferrovias, o que deve realmente aumentar os preços. Como a Ferronorte passa tanto por Rondonópolis quanto por Cuiabá, os preços observados em campo ficaram abaixo do estimado pelo modelo. 
Por um outro lado, estes dois parques industriais são controlados pelas mesmas empresas que operam através de qualquer um destes corredores de exportação. Com isso, a situação apresentada pelo modelo, onde Cuiabá e Rondonópolis não recebem soja, pode ser considerada como pouco provável, pois com a necessidade de abastecer suas fábricas, estas empresas elevarão os preços até conseguirem a quantidade de matéria-prima desejada. Com a capacidade instalada de 1997 (vide Tabela 9), estas indústrias seriam plenamente abastecidas com a soja que iria para Paranaguá e ainda restaria um grande excedente para a exportação.

No entanto, com o fluxo da soja se alterando para outros portos, os projetos de construção de indústrias esmagadoras no norte do país passa a se tornar interessante. Atualmente se observa o interesse de grupos empresariais em construir indústrias em Santarém e São Luís, contando com o sucesso dos corredores de exportação. No entanto, ainda não existe produção de soja suficiente para viabilizar tais empreendimentos, que segundo Fábio Trigueirinho, da $\mathrm{ABIOVE}^{9}$, deve ser da ordem de, no mínimo, 2 milhões de toneladas.

Os dados deste modelo confirmam este enorme potencial de Santarém e São Luís e ainda identifica Vila do Conde (na região metropolitana de Belém) com um bom potencial, apesar de bem menor. Este último pólo depende, para isto, da viabilização completa da navegação nos rios Araguaia e Tocantins (a partir de Marabá), criando assim uma ligação direta entre o leste do Mato Grosso e Belém. Para isto são necessárias, além de outras obras menores, a transposição das quedas de Santa Isabel e a eclusa na usina hidrelétrica de Tucuruí.

\subsection{Inclusão dos dados de regime de chuvas}

A Amazônia como um todo abrange áreas bastante distintas em termos de regime de chuvas. A pluviosidade anual varia de menos de $1.200 \mathrm{~mm}$ para mais de $4.000 \mathrm{~mm}$. Assim, as condições climáticas necessárias para o desenvolvimento da cultura da soja também devem ser analisadas na identificação das áreas viáveis para a sua produção.

\footnotetext{
${ }^{9}$ Informações coletadas em entrevista realizada no dia 06/08/1999
} 
Os dados de regime de chuvas utilizados neste trabalho foram obtidos por Sombroek (1999) em seu trabalho de análise da influência das chuvas no uso da terra na Amazônia. Estes dados foram digitalizados no Imazon, o que permitiu a realização de análise apresentada a seguir. Estes dados não foram incorporados no cenário base pois não são quantitativos nem excludentes, o que apenas permite uma análise qualitativa.

Na Figura 14 e na Tabela 23, podemos identificar as regiões viáveis para a soja, de acordo com o cenário base, sendo separadas pelo regime de chuvas de suas respectivas regiões. As faixas de regime de chuva foram separadas da seguinte forma: i) inviável (acima de $2.800 \mathrm{~mm}$ de chuvas anuais); ii) incerta (entre $2.000 \mathrm{~mm}$ e $2.800 \mathrm{~mm}$ de chuvas anuais); iii) adequada (abaixo de $2.000 \mathrm{~mm}$ de chuvas anuais e com menos de 3 meses com menos de $10 \mathrm{~mm}$ de chuva); e iv) com risco de seca ( 3 ou mais meses com menos de 10 $\mathrm{mm}$ de chuva). Estas faixas foram elaboradas de acordo com os critérios, baseado em entrevistas com o pesquisador da EMBRAPA Vicente Godinho, além de outros fóruns de discussão ${ }^{10}$.

- é inviável o plantio de soja em regiões com precipitações maiores que $2.800 \mathrm{~mm}$ anuais devido à alta incidência de doenças fúngicas e à um número insuficiente de dias com sol;

- para a faixa compreendida entre $2.000 \mathrm{~mm}$ e $2.800 \mathrm{~mm}$ ainda não se dispõe de pesquisas conclusivas sobre a viabilidade técnica de longo prazo da cultura da soja (atualmente existem algumas experiências, como em Santarém, Itacoatiara e Humaitá, mas acredita-se que estas regiões possam ter problemas no futuro com uma alta incidência de doenças fúngicas);

- as áreas abaixo de $2.000 \mathrm{~mm}$ são consideradas adequadas para o plantio da soja e atualmente abrangem as regiões onde existem melhores condições climáticas para o desenvolvimento da soja;

- as regiões com mais de 3 meses com menos de $10 \mathrm{~mm}$ de chuva são consideradas de algum risco, pois são áreas que em anos muito secos podem apresentar perdas

\footnotetext{
${ }^{10}$ Entrevista realizada em 18/10/1999. Além desta entrevista várias pesquisas e discussões científicas envolvendo Embrapa, Banco Mundial e Imazon estão em andamento para se analisar os impactos sociais e ambientais da expansão da soja na Amazônia e alguns dados destes fóruns foram utilizados para este trabalho.
} 
significativas de produtividade (como nos últimos anos observou-se uma intensificação das variações climáticas, como "El Niño" e "La Niña"", estas áreas tendem a ter um alto risco associado à produção).

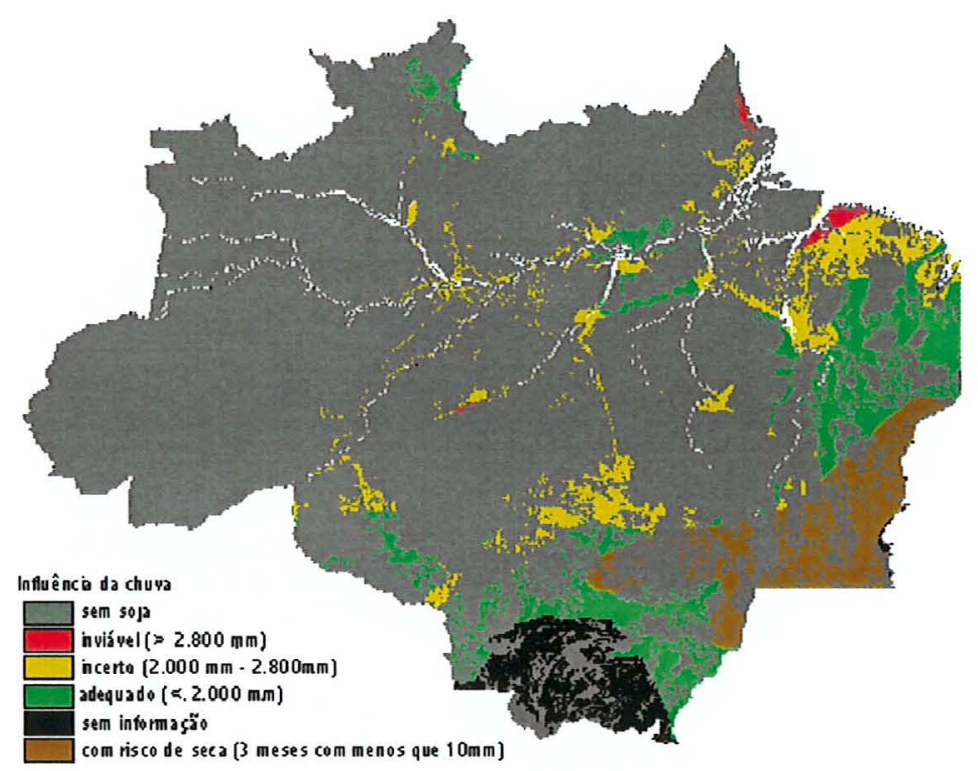

Figura 14. Separação das áreas viáveis para a soja segundo o cenário base de acordo com o regime de chuvas da região

Tabela 23. Total de área abrangida do cenário base por cada uma das faixas de pluviosidade anual.

\begin{tabular}{lcc}
\hline & $\begin{array}{c}\text { Área Plantada } \\
\text { (ha) }\end{array}$ & \multicolumn{1}{c}{$\%$} \\
\hline Inviável & 443.380 & $1,46 \%$ \\
Incerta & 6.676 .565 & $21,98 \%$ \\
Adequada & 12.942 .580 & $42,62 \%$ \\
Risco de seca & 5.835 .480 & $19.21 \%$ \\
Sem dados & 4.469 .850 & $14,72 \%$ \\
\hline AMAZÔNIA & 30.367 .855 & \\
\hline
\end{tabular}

Fonte: dados da pesquisa

Assim, nota-se que as áreas inviáveis devido ao excesso de chuvas (em vermelho na Figura 14) são pouco importantes, se concentrando principalmente nos arredores de Belém, no Amapá e numa pequena região de Apuí (AM). No total, estas áreas representam apenas $1,46 \%$ da área plantada obtida neste cenário.

\footnotetext{
${ }^{11}$ Estes dois efeitos climáticos correspondem a um aquecimento e esfriamento, respectivamente, de uma faixa do oceano Pacífico que afeta todo o clima mundial, causando fortes secas ou inundações em algumas áreas.
} 
As áreas com dúvidas quanto à viabilidade técnica, no entanto, já abrangem uma extensão bastante significativa, abrangendo $21,98 \%$ da área plantada. Nota-se que os estados que mais têm áreas dentro desta faixa são o Pará e o Amazonas. É importante notar que algumas das áreas mais rentáveis, segundo a Figura 10, estão dentro desta faixa, tais como o extremo norte do Mato Grosso e os arredores de Itacoatiara e Santarém.

As áreas adequadas abrangem a maior parte da área viável, segundo o cenário base. Esta faixa abrange $42,62 \%$ do total, mas se considerarmos que as áreas sem dados (em preto) estão nesta faixa (se observarmos na Figura 14, as áreas sem dados são totalmente rodeadas por áreas de pluviosidade adequada), então a participação desta faixa é ainda maior, atingindo $57,34 \%$ do total. Nota-se também que as regiões de produção de soja em atividade atualmente estão dentro desta faixa.

Por fim, as áreas com risco de seca abrangem $19,21 \%$ do total, atingindo principalmente os estados do Tocantins, Maranhão e leste do Mato Grosso.

Assim, pode-se concluir por estes dados que, apesar da maior parte das áreas viáveis para a soja estarem em regiões com pluviosidade adequada, o clima deve ser considerado como um fator importante para o desenvolvimento da soja na Amazônia Legal. Isto porque uma parte significativa estará em regiões onde ainda existem dúvidas quanto à viabilidade técnica de produção de soja, sendo algumas destas as que apresentam as maiores rentabilidades. Além disso, a expansão principal sobre novas áreas está nesta faixa de pluviosidade, onde também se encontram as áreas de florestas.

Com quase a mesma magnitude que as áreas incertas estão as áreas com risco de seca. Algumas destas áreas já têm resultados concretos de perda de produção devido à seca, como é o caso de Canarana (MT), Água Boa (MT) e Gurupi (TO). Na região de Água Boa, por exemplo, existem alguns pecuaristas que utilizam pivôs centrais para irrigar seus pastos, enquanto em Gurupi a agricultura também só é viável com irrigação e, por isto, as op̧̧ões que estão sendo buscadas focam atividades de fruticultura e horticultura. 


\subsection{Cenário 1: ausência de restrições}

Para comparar o potencial dos corredores e o impacto das restrições, na Tabela 24 são apresentados os dados de potencial de escoamento e de área de influência para todos os portos ou agroindústrias da Amazônia Legal, sem no entanto restringir nem a quantidade a ser transportada pelos diversos modais, nem a capacidade de esmagamento das indústrias. Nesta tabela só estão apresentados os dados referentes às áreas que entraram na resposta final, ou seja, que obtiveram receita líquida positiva.

Tabela 24. Produção potencial a ser transportada e área de influência de cada porto ou agroindústria da Amazônia Legal, considerando o cenário base sem nenhuma restrição de carga

\begin{tabular}{lrrrc}
\hline & Produção & \multicolumn{1}{c}{$\%$} & Área Plantada & \multicolumn{1}{c}{$\%$} \\
\hline Santarém (PA) & $37,502,001.00$ & $24 \%$ & $13,093,220.00$ & $23 \%$ \\
São Luís (MA) & $29,749,854.00$ & $19 \%$ & $11,297,405.00$ & $20 \%$ \\
Itacoatiara (AM) & $28,988,244.00$ & $19 \%$ & $10,622,640.00$ & $19 \%$ \\
Vila do Conde (PA) & $19,461,215.00$ & $12 \%$ & $7,605,290.00$ & $13 \%$ \\
Paranaguá (PR) & $17,016,541.00$ & $11 \%$ & $5,582,640.00$ & $10 \%$ \\
Vilhena (RO) & $12,788,489.00$ & $8 \%$ & $4,156,005.00$ & $7 \%$ \\
Santana (AP) & $7,215,779.00$ & $5 \%$ & $2,684,500.00$ & $5 \%$ \\
Caracas(Venezuela) & $2,012,562.00$ & $1 \%$ & $818,860.00$ & $1 \%$ \\
Cáceres (MT) & $1,555,210.00$ & $1 \%$ & $475,370.00$ & $1 \%$ \\
Cuiabá (MT) & 0.00 & $0 \%$ & 0.00 & $0 \%$ \\
Rondonópolis (MT) & 0.00 & $0 \%$ & 0.00 & $0 \%$ \\
Sorriso (MT) & 0.00 & $0 \%$ & 0.00 & $0 \%$ \\
Sinop (MT) & 0.00 & $0 \%$ & 0.00 & $0 \%$ \\
\hline AMAZÔNIA & & & &
\end{tabular}

Fonte: dados da pesquisa

Pelos dados apresentados, Santarém seria o porto com maior potencial em termos de escoamento de soja. O principal fator estimulador é a hidrovia Juruena-Teles Pires-Tapajós, que inicia-se na principal região produtora de soja da Amazônia: Sorriso, Sinop, Lucas do Rio Verde e Nova Mutum. Assim, por este modelo, é possível transportar somente de hidrovia desde a região produtora até o porto, reduzindo substancialmente os custos de transporte. Além disso, Santarém também estimula a produção em todo o percurso da BR 163, em trechos da Transamazônica e na região de Monte Alegre e Alenquer, na margem esquerda do rio Amazonas (vide Figura15). 


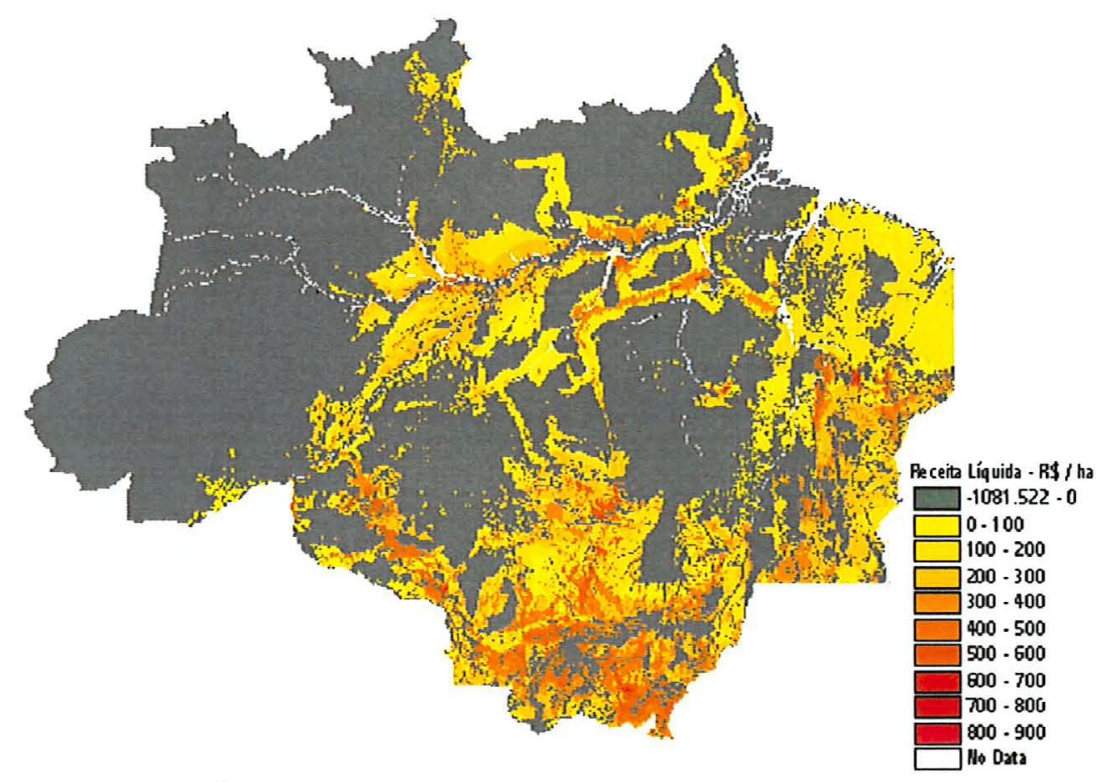

Figura 15. Áreas de influência dos diversos demandantes de soja na Amazônia Legal, segundo o cenário base e sem considerar as restrições de carga e esmagamento.

Os portos de São Luís e Itacoatiara também são de grande importância. A área de influência de São Luís concentra-se principalmente nos cerrados do Maranhão e Tocantins, regiões que vêm apresentando intenso crescimento. Além disso, as ferrovias Norte-Sul e Carajás e a hidrovia do Tapajós exercem uma forte influência no tamanho desta área, pois permitem que o frete até o porto seja mais competitivo.

Itacoatiara, por outro lado, se beneficia principalmente das regiões do cerrado de Rondônia e das áreas desmatadas dos arredores de Manaus e Itacoatiara. Este porto também exerce sua influência sobre as áreas às margens do rio Madeira e no Acre. Sua logística é totalmente dependente do rio Madeira e, por isto, tende a ser um corredor de maiores limitações quando comparado a outros com alternativas multimodais.

Vila do Conde também está baseado em uma hidrovia, mas não sofre o grau de dependência de Itacoatiara. As hidrovias do Araguaia e Tocantins (a partir de Marabá, PA) são a espinha dorsal deste corredor, mas as rodovias PA 150 e BR 158 acompanham paralelamente estes rios, o que dá uma alternativa ao limite das hidrovias. No entanto, com exceção da região leste do Mato Grosso, grande parte destas áreas são pouco aptas ao plantio de grãos, o que diminui naturalmente a importância deste corredor. 
De maneira inversa, a área de influência de Paranaguá, que é o porto de destino da Ferronorte, abrange uma das principais regiões produtoras; entretanto, devido à distância, consegue ser competitiva apenas na área correspondente ao sul e sudeste do Mato Grosso. Estas áreas já estão sendo atualmente utilizadas para produção agrícola, principalmente grãos e pecuária; mas por não serem mais áreas de fronteira, elas já começam a sofrer a competição de outras culturas, como o algodão.

Já Vilhena apresenta uma área de influência significativa porque a indústria situada neste município paga um preço bastante alto. No entanto, sua capacidade de esmagamento é reduzida e esta área tende a ser pouco relevante frente ao total.

Santana, Caracas e Cáceres têm importância menor porque as suas respectivas áreas de influência têm naturalmente pouca aptidão à agricultura. Cáceres apresenta também uma área de influência total bastante reduzida, principalmente relacionada com a longa distância percorrida através da hidrovia do Paraguai até Buenos Aires, o que encarece o transporte a partir deste porto fluvial.

Por fim, os quatro municípios com agroindústrias (Cuiabá, Rondonópolis, Sorriso e Sinop) não entraram na solução pois seus preços não foram competitivos frente aos de Santarém e Paranaguá. O modelo atual demonstra, então, que a conclusão dos projetos de infra-estrutura de transportes deve realmente aumentar os preços pagos da soja nestas regiões, pois os preços atuais das localidades com agroindústria não são competitivos frente aos preços projetados após a finalização destes projetos.

\subsection{Cenário 2: Variação dos preços da soja}

Os valores utilizados neste modelo para os preços da soja foram, em muitos casos, estimativas baseadas nos preços praticados em Paranaguá. Isto porque alguns portos, como Santarém, Santana e Vila do Conde, não operam ainda seus terminais graneleiros, não tendo nenhum preço de referência. Outros portos, como Itacoatiara e São Luís, apresentam dificuldades na obtenção destes dados, que normalmente são restritos à poucas empresas que operam nestes terminais. Os preços obtidos são sempre nas praças produtoras, que teoricamente têm correlação direta com os preços nos portos. 
Isto só não é verdade para o caso da hidrovia do Madeira, onde a única empresa que opera neste corredor paga de forma diferente à lógica do cálculo comum dos preços da soja, que seria o preço no porto menos o frete. Com a previsão de atuação de outra empresa neste corredor para 2000 ou 2001, os preços devem voltar à lógica comum.

Por conta destes fatos, além da grande variabilidade dos preços médios de ano para ano, elaborou-se um cenário variando os preços pagos pela soja nos portos em $10 \%$, tanto positivamente como negativamente. A variação deve ser feita apenas sobre os preços dos portos porque todos os outros preços internos da soja são calculados como o preço no porto mais próximo menos o frete até este porto. Assim, variar 10\% nos preços dos portos significa subtrair ou somar um valor fixo dos preços de cada célula igual a $10 \%$ do preço nos portos.

Os resultados deste cenário podem ser observados nas Tabelas 25 e 26 e a comparação dos mapas com o cenário base está na Figura 16.

Tabela 25. Valores de produção e área plantada considerando uma redução e um aumento de $10 \%$ nos preços da soja nos portos, considerando os parâmetros do cenário base.

\begin{tabular}{|c|c|c|c|c|c|c|c|c|}
\hline & \multicolumn{4}{|c|}{$-10 \%$ para preços } & \multicolumn{4}{|c|}{$+10 \%$ para preços } \\
\hline & $\begin{array}{c}\text { Produção } \\
(\mathbf{t})\end{array}$ & $\%$ & $\begin{array}{l}\text { Área } \\
\text { ( ha ) }\end{array}$ & $\%$ & $\begin{array}{c}\text { Produção } \\
(\mathbf{t})\end{array}$ & $\%$ & $\begin{array}{l}\text { Área } \\
\text { ( ha ) }\end{array}$ & $\%$ \\
\hline Mato Grosso & 27.395 .182 & $51,83 \%$ & 8.941 .380 & $49,40 \%$ & 51.099 .027 & $43,48 \%$ & 16.793 .385 & $39,86 \%$ \\
\hline Tocantins & 9.254 .931 & $17,51 \%$ & 3.573 .745 & $19,75 \%$ & 12.880 .800 & $10,96 \%$ & 5.059 .670 & $12,01 \%$ \\
\hline Pará & 6.447 .597 & $12,20 \%$ & 2.036 .440 & $11,25 \%$ & 22.446 .641 & $19,10 \%$ & 8.786 .050 & $20,85 \%$ \\
\hline Maranhão & 4.827 .951 & $9,13 \%$ & 1.787 .380 & $9,88 \%$ & 16.580 .438 & $14,11 \%$ & 6.189 .015 & $14,69 \%$ \\
\hline Rondônia & 2.094 .650 & $3,96 \%$ & 684.075 & $3,78 \%$ & 5.333 .141 & $4,54 \%$ & 1.815 .765 & $4,31 \%$ \\
\hline Amazonas & 1.485 .090 & $2,81 \%$ & 553.525 & $3,06 \%$ & 3.870 .426 & $3,29 \%$ & 1.442 .665 & $3,42 \%$ \\
\hline Amapá & 862.828 & $1,63 \%$ & 321.265 & $1,78 \%$ & 3.749 .472 & $3,19 \%$ & 1.396 .080 & $3,31 \%$ \\
\hline Roraima & 483.604 & $0,92 \%$ & 200.445 & $1,11 \%$ & 1.562 .028 & $1,33 \%$ & 649.775 & $1,54 \%$ \\
\hline Acre & - & $0,00 \%$ & - & $0,00 \%$ & - & $0,00 \%$ & - & $0,00 \%$ \\
\hline AMAZÔNIA & 52.851 .833 & & 18.098 .255 & & 117.521 .973 & & 42.132 .405 & \\
\hline
\end{tabular}

Fonte: dados da pesquisa

Os dados absolutos obtidos no cenário de redução de preços demonstram que na Amazônia Legal existiriam 18.448.255 ha onde a soja continuaria a ter receita líquida 
positiva mesmo com a redução dos preços. Estas áreas podem ser consideradas como de baixo risco se considerarmos apenas as variações de preços.

Por outro lado, se o mercado internacional se aquecer e os preços subirem $10 \%$ com relação aos preços do cenário base, o potencial da Amazônia cresce para 42.132.405 ha. No entanto, 11.764.620 ha são de alto risco (vide Tabela 26), pois só seriam viáveis com um aumento de $10 \%$ nos preços.

Observa-se pela Figura 16 que as regiões de perdas mais visíveis com a redução dos preços são as áreas próximas ao litoral dos estados do Pará e Maranhão, além das regiões mais ao norte de Rondônia e Roraima. No caso de um aumento de preços, as regiões de Santarém, o sul do Pará e o estado do Amapá são as regiões onde se notam os maiores crescimentos de área. 

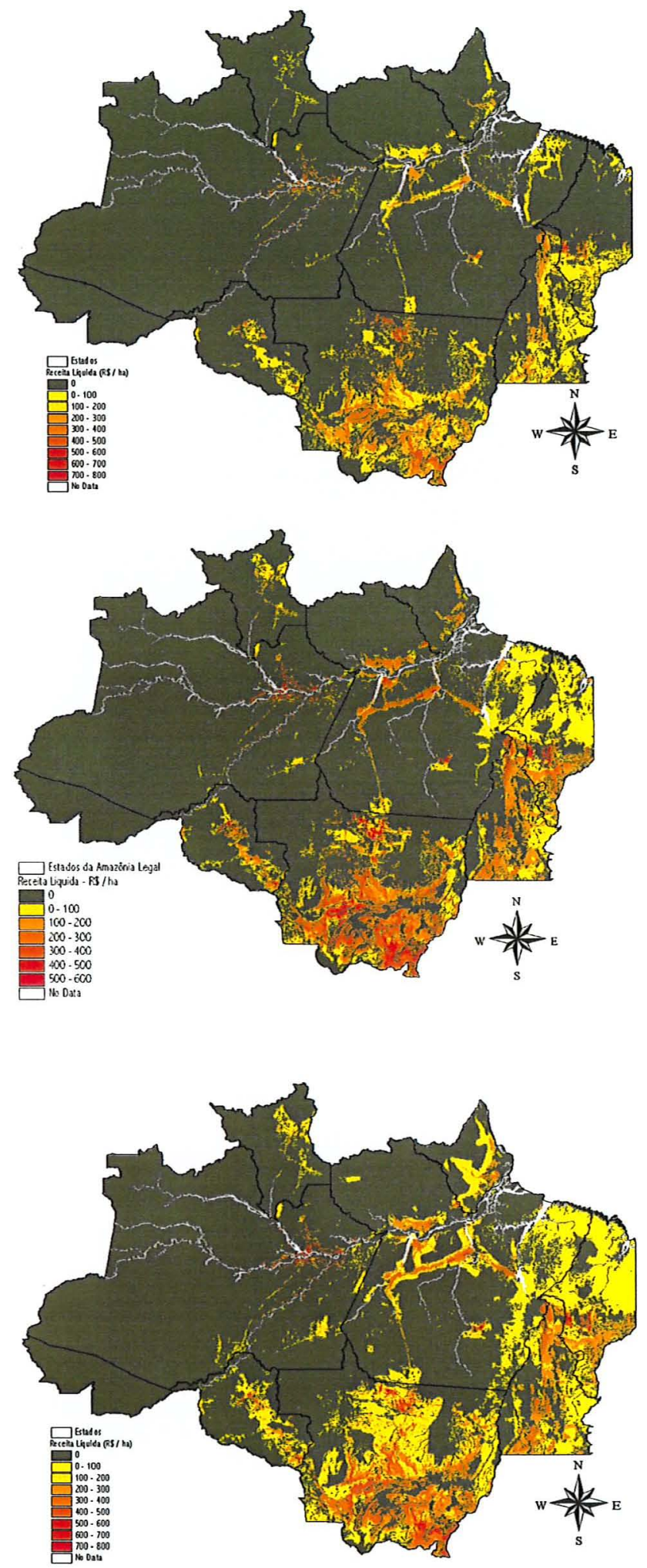

\section{REDUÇÃO DE} $10 \%$ NOS PREÇOS

\section{CENÁRIO BASE}

\section{AUMENTO DE $10 \%$ NOS \\ PREÇOS}

Figura 16. Comparação entre os mapas de variação dos preços e o cenário base A Tabela 26 apresenta a diferença entre estes novos cenários e o cenário base, discriminando os resultados por estado. 
Tabela 26. Variação nos valores de produção e área plantada considerando uma redução e um aumento de $10 \%$ nos preços da soja nos portos, separado por estado.

\begin{tabular}{|c|c|c|c|c|c|c|c|c|}
\hline & \multicolumn{4}{|c|}{$-10 \%$ para preços } & \multicolumn{4}{|c|}{$+10 \%$ para preços } \\
\hline & $\begin{array}{c}\text { Produção } \\
(\mathbf{t})\end{array}$ & $\begin{array}{c}\text { Varia- } \\
\text { ção }\end{array}$ & $\begin{array}{l}\text { Área } \\
\text { ( ha ) }\end{array}$ & $\begin{array}{l}\text { Varia- } \\
\text { ção }\end{array}$ & $\begin{array}{c}\text { Produção } \\
(\mathbf{t})\end{array}$ & $\begin{array}{l}\text { Varia- } \\
\text { ção }\end{array}$ & $\begin{array}{l}\text { Área } \\
\text { ( ha ) }\end{array}$ & $\begin{array}{l}\text { Varia- } \\
\text { ção }\end{array}$ \\
\hline Mato Grosso & $(9.217 .607)$ & $-25,18 \%$ & $(3.053 .050)$ & $-25,45 \%$ & 14.486 .238 & $39,57 \%$ & 4.798 .955 & $40,01 \%$ \\
\hline Tocantins & $(2.820 .551)$ & $-23,36 \%$ & $(1.100 .435)$ & $-23,54 \%$ & 805.318 & $6,67 \%$ & 385.490 & $8,25 \%$ \\
\hline Maranhão & $(9.343 .722)$ & $-65,93 \%$ & $(3.498 .705)$ & $-66,19 \%$ & 2.408 .765 & $17,00 \%$ & 902.930 & $17,08 \%$ \\
\hline Pará & $(7.727 .550)$ & $-54,51 \%$ & $(3.303 .965)$ & $-61,87 \%$ & 8.271 .494 & $58,35 \%$ & 3.445 .645 & $64,52 \%$ \\
\hline Amapá & $(164.122)$ & $-15,98 \%$ & $(61.110)$ & $-15,98 \%$ & 2.722 .522 & $265,11 \%$ & 1.013 .705 & $265,11 \%$ \\
\hline Amazonas & (748.998) & $-33,53 \%$ & $(279.370)$ & $-33,54 \%$ & 1.636 .338 & $73,24 \%$ & 609.770 & $73,21 \%$ \\
\hline Roraima & (949.438) & $-66,25 \%$ & $(395.570)$ & $-66,37 \%$ & 128.986 & $9,00 \%$ & 53.760 & $9,02 \%$ \\
\hline Rondônia & $(1.717 .535)$ & $-45,05 \%$ & $(577.325)$ & $-45,77 \%$ & 1.520 .956 & $39,90 \%$ & 554.365 & $43,95 \%$ \\
\hline Acre & - & $0,00 \%$ & - & $0,00 \%$ & - & $0,00 \%$ & - & $0,00 \%$ \\
\hline AMAZÔNIA & $(32.689 .523)$ & $-38,21 \%$ & $(12.269 .530)$ & $-40,40 \%$ & 31.980 .617 & $37,39 \%$ & 11.764 .620 & $38,74 \%$ \\
\hline
\end{tabular}

Fonte: dados da pesquisa

Pode-se notar que a Tabela 26 confirma os resultados apresentados na Figura 16, com um crescimento expressivo dos estados do Amapá, Pará e Mato Grosso, com destaque para o crescimento relativo do estado do Amapá.

Assim, o Mato Grosso, em qualquer um dos casos, continua sendo o principal produtor da região, pois a queda nos preços afeta a produção e a área plantada, menos intensamente que a maior parte dos outros estados. Por outro lado, com o aumento dos preços, a área aumentada no Mato Grosso é a maior dentre os estados, em termos absolutos.

Os estados do Maranhão, Tocantins e Pará vêm logo após o Mato Grosso. Em termos relativos, no entanto, estes são estados com grande variação de área. Excluindo o Mato Grosso, estes são os estados com maiores perdas de área, estando também entre os principais em termos relativos. Com relação ao aumento de preços, o Tocantins cresce apenas $8,25 \%$ em área, menos que o aumento relativo dos preços. Em compensação, o Pará tem um crescimento de 64,52\%e o Maranhão, de 17,08\%. Este crescimento do Pará só não é maior que os estados de Rondônia e Amazonas, em termos relativos, e que o Mato Grosso, em termos absolutos. 
Para os outros estados, apesar de em termos relativos serem significativas, as variações em termos absolutos são muito pequenas, com exceção do Amapá, que aumenta sua área plantada em mais de $200 \%$ com o aumento de preços. Mesmo assim, este estado não consegue participação maior que 5\% no total de área potencial para a soja na Amazônia Legal.

Com relação aos efeitos sobre o desmatamento, a Tabela 27 mostra que as maiores variações em termos relativos estão relacionadas com as áreas de florestas. Por serem áreas com alto custo (e portanto, com receitas líquidas menores), a redução dos preços faz com que muito mais áreas de florestas deixem de ser convertidas em agricultura, em comparação às áreas de cerrado e já alteradas.

Tabela 27. Variação nos valores de produção e área plantada considerando uma redução e um aumento de $10 \%$ nos preços da soja nos portos, separado por tipo de vegetação anterior à soja.

\begin{tabular}{lccccccccc}
\hline & \multicolumn{3}{c}{$-\mathbf{- 1 0} \%$ para preços } & \multicolumn{4}{c}{$+\mathbf{1 0} \%$ para preços } \\
& $\begin{array}{c}\text { Produção } \\
(\mathbf{t})\end{array}$ & $\begin{array}{c}\text { Varia- } \\
\text { ção }\end{array}$ & $\begin{array}{c}\text { Área } \\
(\mathbf{h a})\end{array}$ & $\begin{array}{c}\text { Varia- } \\
\text { ção }\end{array}$ & $\begin{array}{c}\text { Produção } \\
(\mathbf{t})\end{array}$ & $\begin{array}{c}\text { Varia- } \\
\text { ção }\end{array}$ & $\begin{array}{c}\text { Área } \\
(\text { ha })\end{array}$ & $\begin{array}{c}\text { Varia- } \\
\text { ção }\end{array}$ \\
\hline Alteradas & $(23.264 .167)$ & $-45,92 \%$ & $(7.525 .490)$ & $-41,82 \%$ & 7.024 .577 & $13,87 \%$ & 3.065 .370 & $17,04 \%$ \\
Cerrado & $(10.178 .455)$ & $-32,45 \%$ & $(3.667 .335)$ & $-32,73 \%$ & 5.410 .575 & $17,25 \%$ & 1.963 .255 & $17,52 \%$ \\
Floresta & $(3.245 .868)$ & $-92,27 \%$ & $(1.076 .705)$ & $-92,22 \%$ & 19.545 .465 & $555,61 \%$ & 6.735 .995 & $576,93 \%$ \\
AMAZÔNIA & $(36.688 .490)$ & & $(12.269 .530)$ & & 31.980 .617 & & 11.764 .620 & \\
\hline
\end{tabular}

Fonte: dados da pesquisa

É interessante notar que as áreas com cerrado diminuem menos que as áreas alteradas anteriormente à agricultura. Como estas últimas áreas têm custos menores, seria de se supor que fossem as de maior potencial. Entretanto, as principais áreas que saíram da solução final são áreas com baixas produtividades, principalmente no litoral do Maranhão e Pará, áreas estas já desmatadas.

$\mathrm{O}$ aumento de preços gera um efeito completamente diferente sobre a vegetação. A área plantada sobre cerrados e áreas já alteradas crescem em taxas bastante semelhantes, com diferenças apenas nos valores absolutos. Para as áreas com florestas, no entanto, o efeito é devastador. O aumento de $10 \%$ nos preços gera um crescimento de $576,93 \%$ da área plantada, o que significa que pouco mais de 7,9 milhões ha de florestas têm o potencial de serem convertidos em plantios de soja. 


\subsection{Cenário 3: Variação dos custos de produção}

Da mesma forma que os preços da soja, os preços dos insumos são bastante variáveis. O caso principal são os preços dos adubos, que dependem de inúmeros fatores tais como disponibilidade de nutrientes no mercado mundial, demanda concentrada em períodos específicos, época de liberação dos financiamentos, dentre outros.

Além disso, o preço dos fretes também tem oscilações ao longo do tempo decorrentes de deterioração das estradas, aumento de combustíveis, cobrança de pedágios, etc.

Com isso, simulou-se uma variação de $10 \%$ nos custos de produção de cada célula. Isto significa que os dados de custo de produção do cenário base foram multiplicados por 0,9 ou 1,1 para se obter os mapas com redução e aumento destes custo, respectivamente.

Os resultados deste cenário, em termos de produção e área plantada, estão apresentados na Tabela 28. Na Figura 17 estes dados são espacializados e na Tabela 29 apresentam-se os resultados em termos relativos ao cenário base.

Tabela 28. Produção e área plantada considerando uma redução e um aumento de $10 \%$ nos custos de produção da soja, separado por estado.

\begin{tabular}{|c|c|c|c|c|c|c|c|c|}
\hline & \multicolumn{4}{|c|}{$-10 \%$ para custo de produção } & \multicolumn{4}{|c|}{$+10 \%$ para custo de produção } \\
\hline & $\begin{array}{c}\text { Produção } \\
\text { (t ) }\end{array}$ & $\%$ & $\begin{array}{l}\text { Área } \\
\text { (ha ) }\end{array}$ & $\%$ & $\begin{array}{c}\text { Produção } \\
(\mathbf{t})\end{array}$ & $\%$ & $\begin{array}{l}\text { Área } \\
\text { (ha ) }\end{array}$ & $\%$ \\
\hline Mato Grosso & 48.967 .218 & $42,81 \%$ & 16.096 .395 & $39,21 \%$ & 30.357 .069 & $50,41 \%$ & 9.917 .705 & $47,10 \%$ \\
\hline Pará & 22.121 .136 & $19,34 \%$ & 8.648 .465 & $21,07 \%$ & 8.192 .399 & $13,60 \%$ & 3.034 .990 & $14,41 \%$ \\
\hline Maranhão & 16.542 .650 & $14,46 \%$ & 6.174 .945 & $15,04 \%$ & 5.475 .193 & $9,09 \%$ & 2.039 .310 & $9,69 \%$ \\
\hline Tocantins & 12.870 .802 & $11,25 \%$ & 5.055 .925 & $12,32 \%$ & 10.144 .250 & $16,85 \%$ & 3.927 .560 & $18,65 \%$ \\
\hline Rondônia & 5.200 .454 & $4,55 \%$ & 1.771 .070 & $4,31 \%$ & 3.009 .175 & $5,00 \%$ & 981.505 & $4,66 \%$ \\
\hline Amapá & 3.781 .056 & $3,31 \%$ & 1.407 .840 & $3,43 \%$ & 870.252 & $1,45 \%$ & 324.030 & $1,54 \%$ \\
\hline Amazonas & 3.346 .538 & $2,93 \%$ & 1.247 .470 & $3,04 \%$ & 1.664 .208 & $2,76 \%$ & 620.270 & $2,95 \%$ \\
\hline Roraima & 1.560 .096 & $1,36 \%$ & 648.970 & $1,58 \%$ & 507.050 & $0,84 \%$ & 210.210 & $1,00 \%$ \\
\hline Acre & - & $0,00 \%$ & - & $0,00 \%$ & - & $0,00 \%$ & - & $0,00 \%$ \\
\hline AMAZÔNIA & 114.389 .950 & & 41.051 .080 & & 60.219 .596 & & 21.055 .580 & \\
\hline
\end{tabular}

Fonte: dados da pesquisa

A variação nos custos de produção tem um efeito mais acentuado na variação da área plantada que o causado pela alteração nos preços. Neste cenário, 43.741 .950 ha e 
21.055.580 ha são utilizados para a produção de grãos com a redução e com o aumento de $10 \%$ nos custos, respectivamente. Enquanto isso, no cenário de variação de preços, a área ocupada com soja fica em 18.448.225 ha e 42.132 .405 ha para a redução e aumento de $10 \%$ nos preços, o que significa uma variação de $2,67 \%$ em módulo entre os cenários pessimistas e de $3,82 \%$ entre os otimistas. Isto demonstra que o aumento de área plantada é mais sensível a uma redução de custos do que a um aumento de preços.

Isto pode ser explicado pelo fato de a variação de preços ser absoluta, ou seja somase ou subtrai-se um valor fixo, enquanto a de custos é relativa. Com isto, no primeiro caso, regiões com preços altos sofrem um impacto menor em termos percentuais do que outras com preços menores. Já no segundo caso, a variação percentual é uniforme, o que faz com que regiões com custos de produção mais altos observem variações absolutas mais acentuadas que regiões com custos menores. 

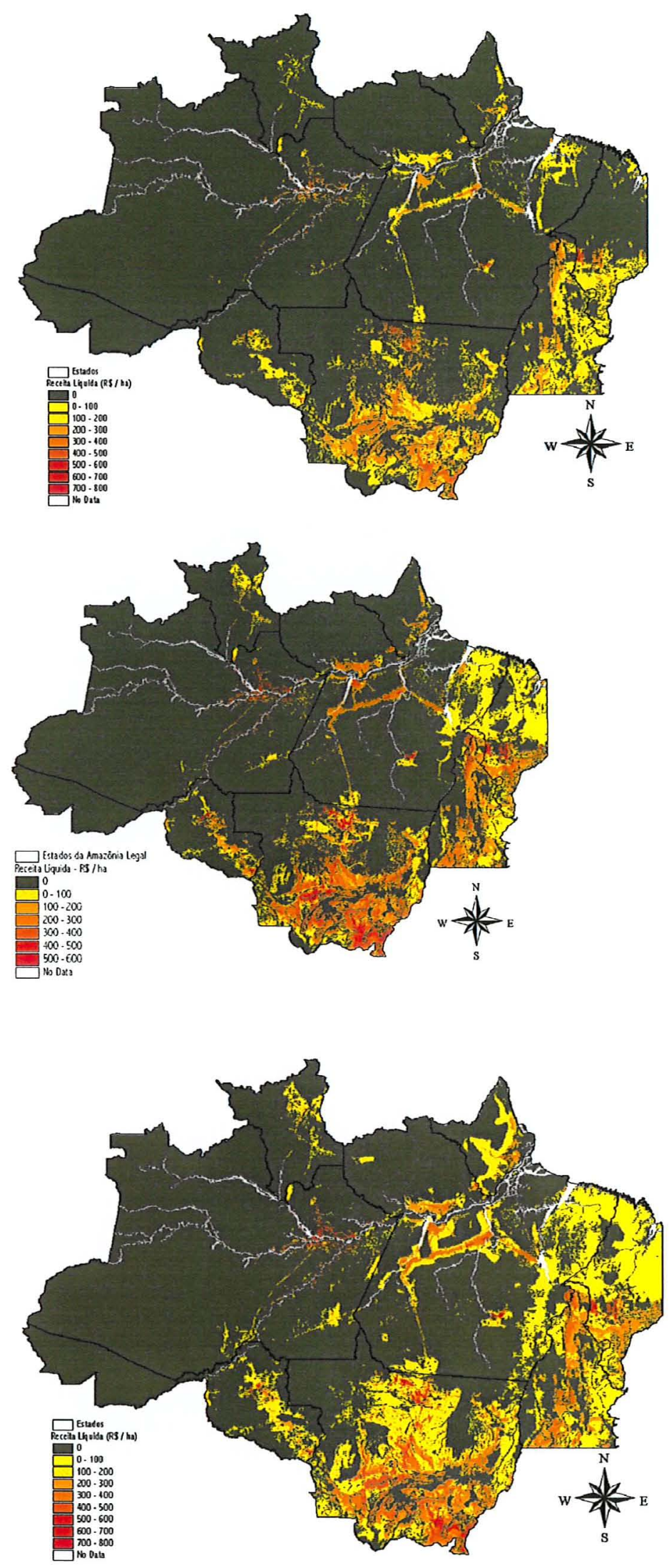

AUMENTO DE $10 \%$ NOS CUSTOS DE PRODUCÃO
CENÁRIO

BASE

\section{REDUÇÃO DE $10 \%$ NOS CUSTOS DE PRODUCÃO}

Figura 17. Comparação entre os mapas de variação dos custos de produção e o cenário base. 
Pode-se observar, no entanto, que este cenário não altera substancialmente a participação dos estados no total de área plantada. No entanto, nota-se claramente três agrupamentos distintos de estados, considerando o total de área plantada: i) Mato Grosso; ii) Tocantins, Pará e Maranhão e iii) Rondônia, Amapá, Roraima, Amazonas e Acre. Esta sub-divisão pode ser aplicada também ao cenário de variação de preços.

Assim, os estados com as maiores quantidades de áreas estáveis, ou seja, áreas que se mantêm na solução mesmo com um aumento nos custos de produção, são o Mato Grosso, o Pará, o Tocantins e o Maranhão, justamente os estados dos agrupamentos (i) e (ii).

Por outro lado, pela Tabela 29 pode-se observar que os estados do Maranhão, Pará e Mato Grosso são os que têm a maior quantidade de área no cenário base com baixas receitas líquidas, o que significa alto risco para variações nos custos de produção.

Tabela 29. Variação na produção e área plantada considerando uma redução e um aumento de $10 \%$ nos custos de produção da soja, separado por estado.

\begin{tabular}{lccccccccc}
\hline & \multicolumn{3}{c}{$\mathbf{- 1 0} \%$} & para custos de produção & \multicolumn{3}{c}{$+\mathbf{+ 1 0} \%$ para custos de produção } \\
\hline & $\begin{array}{c}\text { Produção } \\
(\mathbf{t})\end{array}$ & $\begin{array}{c}\text { Varia- } \\
\text { ção }\end{array}$ & $\begin{array}{c}\text { Área } \\
(\mathbf{h a})\end{array}$ & $\begin{array}{c}\text { Varia- } \\
\text { ção }\end{array}$ & $\begin{array}{c}\text { Produção } \\
(\mathbf{t})\end{array}$ & $\begin{array}{c}\text { Varia- } \\
\text { ção }\end{array}$ & $\begin{array}{c}\text { Área } \\
(\text { ha })\end{array}$ & $\begin{array}{c}\text { Varia- } \\
\text { ção }\end{array}$ \\
\hline Mato Grosso & 12.354 .429 & $33,74 \%$ & 4.101 .965 & $34,20 \%$ & $(6.255 .720)$ & $-17,09 \%$ & $(2.076 .725)$ & $-17,31 \%$ \\
Tocantins & 795.320 & $6,59 \%$ & 381.745 & $8,17 \%$ & $(1.931 .232)$ & $-15,99 \%$ & $(746.620)$ & $-15,97 \%$ \\
Maranhão & 2.370 .977 & $16,73 \%$ & 888.860 & $16,82 \%$ & $(8.696 .480)$ & $-61,37 \%$ & $(3.246 .775)$ & $-61,42 \%$ \\
Pará & 7.945 .989 & $56,06 \%$ & 3.308 .060 & $61,94 \%$ & $(5.982 .748)$ & $-42,21 \%$ & $(2.305 .415)$ & $-43,17 \%$ \\
Amapá & 2.754 .106 & $268,18 \%$ & 1.025 .465 & $268,18 \%$ & $(156.698)$ & $-15,26 \%$ & $(58.345)$ & $-15,26 \%$ \\
Amazonas & 1.112 .450 & $49,79 \%$ & 414.575 & $49,78 \%$ & $(569.880)$ & $-25,51 \%$ & $(212.625)$ & $-25,53 \%$ \\
Roraima & 127.054 & $8,87 \%$ & 52.955 & $8,88 \%$ & $(925.992)$ & $-64,62 \%$ & $(385.805)$ & $-64,73 \%$ \\
Rondônia & 1.388 .269 & $36,42 \%$ & 509.670 & $40,41 \%$ & $(803.010)$ & $-21,06 \%$ & $(279.895)$ & $-22,19 \%$ \\
Acre & - & $0,00 \%$ & - & $0,00 \%$ & - & $0,00 \%$ & - & $0,00 \%$ \\
\hline AMAZÔNIA & 28.848 .594 & $33,72 \%$ & 10.683 .295 & $35,18 \%$ & $(25.321 .760)$ & $-29,60 \%$ & $(9.312 .205)$ & $-30,66 \%$ \\
\hline
\end{tabular}

Fonte: dados da pesquisa

Em termos relativos, no entanto, os estados que perderam a maior parte de suas áreas com soja são Roraima, Maranhão e Pará. Nota-se assim que os estados do Maranhão e Pará são bastante vulneráveis às variações econômicas, pois tanto no cenário de redução de preços quanto no de aumento de custos eles estão entre os que perderam maiores áreas. 
Roraima, no entanto, é sensível apenas em termos relativos, uma vez que sua área de produção, e também a sua área impactada, é bem menor que a dos outros estados.

O Mato Grosso é o estado que possui grandes quantidades tanto de áreas estáveis quanto de áreas sensíveis a estas variações, uma vez que apresenta variações significativas a uma redução nos custos, mas também possui a maior quantidade de área estável. Por ser o estado com maior área apta à soja, este é também o que congrega a maior variabilidade de receitas líquidas.

A análise da redução dos custos, no entanto, não altera a avaliação do comportamento dos estados principais. Os que tiveram maiores variações absolutas foram os estados do Mato Grosso e Pará, seguidos pelo Amapá e Maranhão. No entanto, em termos relativos, o estado do Amapá se destaca, com um aumento de 268,18\% em sua área plantada, seguido pelos estados do Pará e Amazonas.

Estes estados apresentam áreas com custos de produção bastante próximos da receita obtida com a soja, o que explica a sua entrada na solução com a redução nos custos. Sendo assim, da mesma forma que no cenário de aumento de preços, estas áreas que entraram na solução são de alto risco econômico para a produção de soja.

A Tabela 30 apresenta a variação da área e da produção de soja, considerando a vegetação existente anteriormente.

Tabela 30. Variação nos valores de produção e área plantada considerando uma redução e um aumento de $10 \%$ nos custos de produção da soja, separado por tipo de vegetação anterior à soja.

\begin{tabular}{|c|c|c|c|c|c|c|c|c|}
\hline & \multicolumn{4}{|c|}{$+10^{\prime} \%$ para custo de produção } & \multicolumn{4}{|c|}{$-10^{\prime} \%$ para custo de produção } \\
\hline & $\begin{array}{c}\text { Produção } \\
(t)\end{array}$ & $\begin{array}{c}\text { Varia- } \\
\text { ção }\end{array}$ & $\begin{array}{l}\text { Área } \\
\text { (ha ) }\end{array}$ & $\begin{array}{l}\text { Varia- } \\
\text { ção }\end{array}$ & $\begin{array}{c}\text { Produção } \\
\text { (t) }\end{array}$ & $\begin{array}{l}\text { Varia- } \\
\text { ção }\end{array}$ & $\begin{array}{l}\text { Área } \\
\text { (ha ) }\end{array}$ & $\begin{array}{l}\text { Variam } \\
\text { ção }\end{array}$ \\
\hline Alteradas & $(23.264 .167)$ & $-45,92 \%$ & $(7.525 .490)$ & $-41,82 \%$ & 7.024 .577 & $13,87 \%$ & 3.065 .370 & $17,04 \%$ \\
\hline Cerrado & $(10.178 .455)$ & $-32,45 \%$ & $(3.667 .335)$ & $-32,73 \%$ & 5.410 .575 & $17,25 \%$ & 1.963 .255 & $17,52 \%$ \\
\hline Floresta & $(3.245 .868)$ & $-92,27 \%$ & $(1.076 .705)$ & $-92,22 \%$ & 19.545.465 & $555,61 \%$ & 6.735 .995 & $576,93 \%$ \\
\hline AMAZÔNIA & $(36.688 .490)$ & & $(12.269 .530)$ & & 31.980 .617 & & 11.764 .620 & \\
\hline
\end{tabular}

Fonte: dados da pesquisa

Da mesma forma que no cenário anterior, o tipo de vegetação que mais sofre o impacto das variações de custos são as florestas. A redução de custos gera uma aumento de área plantada maior que $500 \%$, enquanto um aumento de custos a reduz em $84,17 \%$. Com 
relação aos outros tipos de vegetação, o mesmo comportamento do cenário anterior pode ser observado, ou seja, as áreas alteradas anteriormente sofrem mais o impacto que as áreas de cerrado.

Nota-se assim que anos bons para a soja, tanto em termos de preços quanto em termos de redução de custos, podem ter um efeito bastante significativo no desmatamento, aumentando de 6 milhões de ha a 11 milhões de ha a área desmatada para a introdução direta de agricultura. No entanto, isto ocorrerá apenas se a conjuntura favorável se repetir por pelo menos 5 anos, uma vez que este modelo considerou que o custo de abertura de área teria retorno neste período de referência.

\subsection{Cenário 4: Variação das produtividades}

A produtividade é um parâmetro que também tende a sofrer variações com o tempo, tanto de curto prazo como de longo prazo. No curto prazo, uma variação climática, um ataque de pragas ou doenças ou até uma má regulagem de máquinas pode afetar a produtividade final de um produtor.

No longo prazo, por outro lado, o melhoramento genético, a melhoria das práticas agrícolas e o desenvolvimento de novas tecnologias e produtos tendem a aumentar a produtividade das culturas agrícolas ao longo do tempo.

Assim, desenvolve-se um cenário com a variação de $10 \%$ na produtividade de cada célula. Da mesma forma que no cenário anterior, isto significa a multiplicação do valor de cada célula por 0,9 e 1,1 para a redução e aumento, respectivamente, das produtividades.

Os resultados deste cenário podem ser observados nas Tabelas 31, 32 e 33 e na Figura 18. 
Tabela 31. Produção e área plantada considerando uma redução e um aumento de $10 \%$ nas produtividades da soja, separado por estado.

\begin{tabular}{|c|c|c|c|c|c|c|c|c|}
\hline & \multicolumn{4}{|c|}{$-10 \%$ para produtividades } & \multicolumn{4}{|c|}{$+10 \%$ para produtividades } \\
\hline & $\begin{array}{c}\text { Produção } \\
\text { (t) }\end{array}$ & $\%$ & $\begin{array}{l}\text { Área } \\
\text { ( ha ) }\end{array}$ & $\%$ & $\begin{array}{c}\text { Produção } \\
\text { (t) }\end{array}$ & $\%$ & $\begin{array}{l}\text { Área } \\
\text { ( ha ) }\end{array}$ & $\%$ \\
\hline Mato Grosso & 29.887 .605 & $51,54 \%$ & 9.762 .725 & $48,23 \%$ & 48.142 .908 & $43,02 \%$ & 15.821 .750 & $39,41 \%$ \\
\hline Tocantins & 9.952 .998 & $17,16 \%$ & 3.852 .485 & $19,03 \%$ & 12.862 .538 & $11,49 \%$ & 5.017 .635 & $20,57 \%$ \\
\hline Pará & 7.066 .403 & $12,19 \%$ & 2.617 .755 & $12,93 \%$ & 21.110 .703 & $18,86 \%$ & 8.259 .160 & $15,24 \%$ \\
\hline Maranhão & 5.179 .559 & $8,93 \%$ & 1.926 .400 & $9,52 \%$ & 16.393 .971 & $14,65 \%$ & 6.119 .575 & $12,50 \%$ \\
\hline Rondônia & 2.925 .026 & $5,04 \%$ & 952.875 & $4,71 \%$ & 5.164 .631 & $4,61 \%$ & 1.758 .505 & $4,38 \%$ \\
\hline Amazonas & 1.616 .550 & $2,79 \%$ & 602.525 & $2,98 \%$ & 3.228 .382 & $2,88 \%$ & 1.238 .405 & $3,20 \%$ \\
\hline Amapá & 867.996 & $1,50 \%$ & 323.190 & $1,60 \%$ & 3.453 .372 & $3,09 \%$ & 1.285 .830 & $3,08 \%$ \\
\hline Roraima & 490.240 & $0,85 \%$ & 203.210 & $1,00 \%$ & 1.554 .636 & $1,39 \%$ & 646.695 & $1,61 \%$ \\
\hline Acre & - & $0,00 \%$ & - & $0,00 \%$ & - & $0,00 \%$ & - & $0,00 \%$ \\
\hline AMAZÔNIA & 57.986 .377 & & 20.241 .165 & & 111.911 .141 & & 40.147 .555 & \\
\hline
\end{tabular}

Fonte: dados da pesquisa

Considerando toda a Amazônia, a variação na produtividade gera resultados levemente diferentes do cenário de variação nos custos de produção. O aumento de $10 \%$ na produtividade aumenta a área plantada para mais de 40,1 milhões de ha, enquanto a redução na mesma magnitude leva a área plantada para cerca de 20,2 milhões de ha. No cenário de custos de produção, os valores obtidos foram 43,7 milhões de ha e 21,0 milhões de ha, enquanto no de preços, 42,1 milhões de ha e 18,4 milhões de ha. Observa-se, assim, que este cenário é o que menos aumenta a área plantada dentre os cenários otimistas e o segundo que mais aumenta dentre os pessimistas.

A disposição dos estados nos três agrupamentos descritos no cenário anterior também se mantém clara neste cenário. O Mato Grosso é o estado com maior área plantada, seguido pelos estados do Tocantins, Maranhão e Pará. 
Tabela 32. Produção e área plantada considerando uma redução e um aumento de $10 \%$ nas produtividades da soja, separado por estado.

\begin{tabular}{lcccccccc}
\hline & \multicolumn{3}{c}{$\mathbf{- 1 0} \%$ para produtividades } & \multicolumn{4}{c}{$+\mathbf{+ 1 0} \%$ para produtividades } \\
\hline & $\begin{array}{c}\text { Produção } \\
(\mathbf{t})\end{array}$ & $\begin{array}{c}\text { Varia- } \\
\text { ção }\end{array}$ & $\begin{array}{c}\text { Área } \\
\text { (ha })\end{array}$ & $\begin{array}{c}\text { Varia- } \\
\text { ção }\end{array}$ & $\begin{array}{c}\text { Produção } \\
(\mathbf{t})\end{array}$ & $\begin{array}{c}\text { Varia- } \\
\text { ção }\end{array}$ & $\begin{array}{c}\text { Área } \\
(\mathbf{h a})\end{array}$ & $\begin{array}{c}\text { Varia- } \\
\text { ção }\end{array}$ \\
\hline Mato Grosso & $(6.725 .184)$ & $-18,37 \%$ & $(2.231 .705)$ & $-18,61 \%$ & 11.530 .119 & $31,49 \%$ & 3.827 .320 & $31,91 \%$ \\
Tocantins & $(2.122 .484)$ & $-17,58 \%$ & $(821.695)$ & $-17,58 \%$ & 787.056 & $6,52 \%$ & 343.455 & $7,35 \%$ \\
Maranhão & $(8.992 .114)$ & $-63,45 \%$ & $(3.359 .685)$ & $-63,56 \%$ & 2.222 .298 & $15,68 \%$ & 833.490 & $15,77 \%$ \\
Pará & $(7.108 .744)$ & $-50,15 \%$ & $(2.722 .650)$ & $-50,98 \%$ & 6.935 .556 & $48,93 \%$ & 2.918 .755 & $54,65 \%$ \\
Amapá & $(158.954)$ & $-15,48 \%$ & $(59.185)$ & $-15,48 \%$ & 2.426 .422 & $236,27 \%$ & 903.455 & $236,27 \%$ \\
Amazonas & $(617.538)$ & $-27,64 \%$ & $(230.370)$ & $-27,66 \%$ & 994.294 & $44,51 \%$ & 405.510 & $48,69 \%$ \\
Roraima & $(942.802)$ & $-65,79 \%$ & $(392.805)$ & $-65,91 \%$ & 121.594 & $8,49 \%$ & 50.680 & $8,50 \%$ \\
Rondônia & $(887.159)$ & $-23,27 \%$ & $(308.525)$ & $-24,46 \%$ & 1.352 .446 & $35,48 \%$ & 497.105 & $39,41 \%$ \\
Acre & & $0,00 \%$ & - & $0,00 \%$ & - & $0,00 \%$ & - & $0,00 \%$ \\
\hline AMAZÔNIA & $(27.554 .979)$ & $-32,21 \%$ & $(10.126 .620)$ & $-33,35 \%$ & 26.369 .785 & $30,83 \%$ & 9.779 .770 & $32,20 \%$ \\
\hline
\end{tabular}

Fonte: dados da pesquisa 

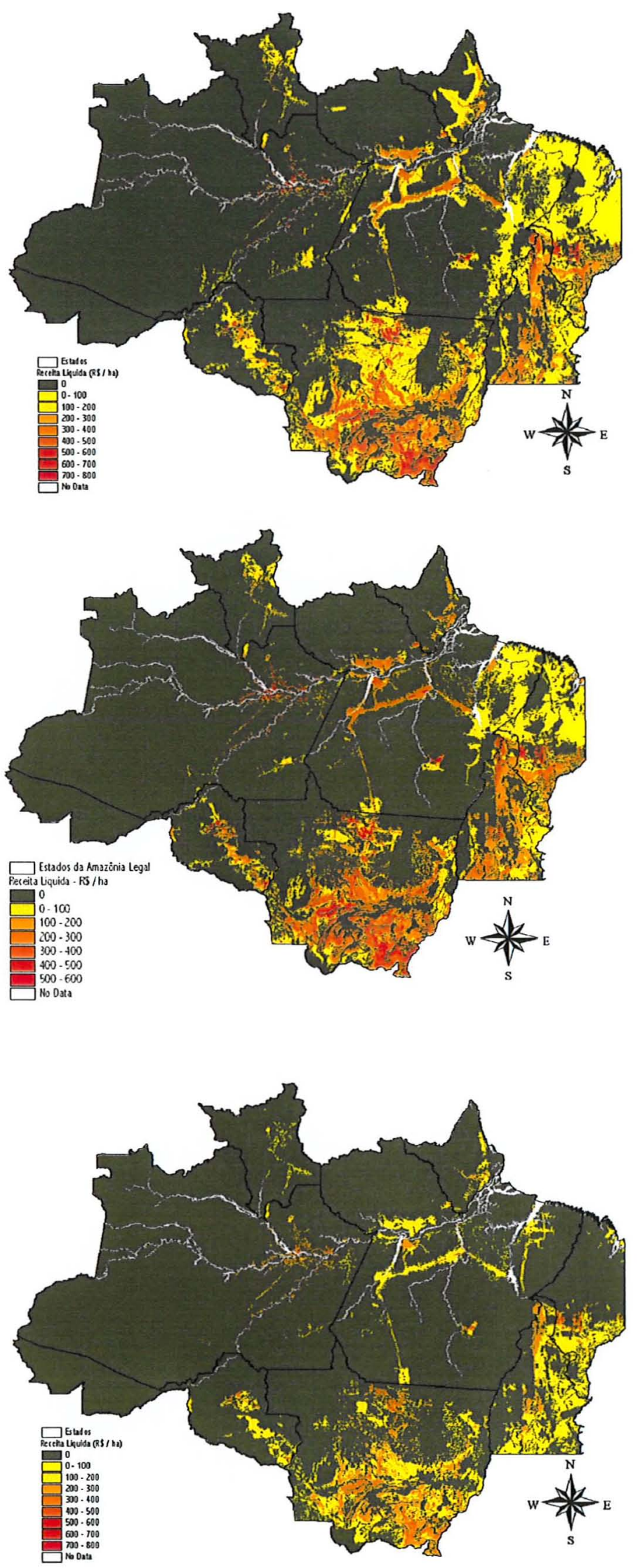

AUMENTO DE $10 \%$ NAS PRODUTIVIDADES

CENÁRIO BASE

\section{REDUÇÃO DE $10 \%$ NA}

PRODUTIVIDADE

Figura 18. Comparação entre os mapas de variação das produtividades e o cenário base. 
No entanto, se compararmos as variações percentuais na área de cada estado no cenário de aumento de produtividade, observa-se que a maior variação absoluta é do estado do Mato Grosso. Entretanto, em termos relativos, o Amapá é o estado com maior variação positiva, mais do que dobrando sua área plantada com o aumento da produtividade. Outros estados com variações bastante significativas são o Maranhão, o Amazonas e Rondônia.

Com relação ao cenário pessimista, os estados com maiores reduções absolutas são o Pará, o Maranhão e o Mato Grosso. Em termos relativos, os estados do Roraima, Pará e Maranhão são os que observam maiores reduções. Nota-se assim que Pará e Maranhão são estados que sofrem um grande impacto com a redução da produtividade da soja.

Tabela 33. Variação nos valores de produção e área plantada considerando uma redução e um aumento de $10 \%$ nas produtividades da soja, separado por tipo de vegetação anterior à soja.

\begin{tabular}{lccccccccc}
\hline & \multicolumn{3}{c}{$\mathbf{- 1 0} \%$ para produtividades } & \multicolumn{3}{c}{$+\mathbf{+ 1 0} \%$ para produtividades } \\
\hline & $\begin{array}{c}\text { Produção } \\
(\mathbf{t})\end{array}$ & $\begin{array}{c}\text { Varia- } \\
\text { ção }\end{array}$ & $\begin{array}{c}\text { Área } \\
(\text { ha })\end{array}$ & $\begin{array}{c}\text { Varia- } \\
\text { ção }\end{array}$ & $\begin{array}{c}\text { Produção } \\
(\mathbf{t})\end{array}$ & $\begin{array}{c}\text { Varia- } \\
\text { ção }\end{array}$ & $\begin{array}{c}\text { Área } \\
\text { (ha })\end{array}$ & $\begin{array}{c}\text { Varia- } \\
\text { ção }\end{array}$ \\
\hline Alteradas & $(23.264 .167)$ & $-45,92 \%$ & $(7.525 .490)$ & $-41,82 \%$ & 7.024 .577 & $13,87 \%$ & 3.065 .370 & $17,04 \%$ \\
Cerrado & $(10.178 .455)$ & $-32,45 \%$ & $(3.667 .335)$ & $-32,73 \%$ & 5.410 .575 & $17,25 \%$ & 1.963 .255 & $17,52 \%$ \\
Floresta & $(3.245 .868)$ & $-92,27 \%$ & $(1.076 .705)$ & $-92,22 \%$ & 19.545 .465 & $555,61 \%$ & 6.735 .995 & $576,93 \%$ \\
AMAZÔNIA & $(36.688 .490)$ & & $(12.269 .530)$ & & 31.980 .617 & & 11.764 .620 & \\
\hline
\end{tabular}

Fonte: dados da pesquisa

A variação com relação à vegetação segue a mesma regra dos cenário anteriores, ou seja, o maior impacto é sempre sobre as áreas de florestas, tanto positivamente quanto negativamente. Neste cenário, no entanto, a variação sobre os cerrados para o aumento nas produtividades é maior que nas áreas já desmatadas, diferentemente dos cenários anteriores, onde sempre as áreas desmatadas variavam mais que os cerrados.

\subsection{Cenário 5: Asfaltamento da BR 163}

Dentre os projetos rodoviários previstos no Programa "Avança Brasil", um dos que vêm demandando grande discussão é o asfaltamento total da BR 163, também chamada de Cuiabá-Santarém. Esta rodovia atualmente é a principal opção para o escoamento da soja produzida no norte do Mato Grosso, que se direciona a Cuiabá, Rondonópolis ou outras 
localidades no Sul e Sudeste do país. O trecho a ser asfaltado nesta rodovia corresponde, principalmente, à parte que atravessa o estado do Pará até o município de Rurópolis (PA).

A implantação deste projeto desenvolverá um corredor importante, que tanto permitirá o transporte da soja para o norte (com acesso ao porto de Santarém) como o escoamento de produtos da Amazônia para os estados mais ao sul. Este corredor é considerado de grande importância para as regiões norte do Mato Grosso e oeste do Pará, pois tendem a dinamizar as suas economias, existindo inclusive movimentos para a criação de dois novos estados: o de Mato Grosso do Norte e o de Tapajós. O caminho percorrido pelos produtos oriundos da Zona Franca de Manaus também é reduzido com este corredor, o que também é considerado como um importante incentivo para a sua finalização.

Assim, nota-se que este projeto tem uma importância bastante grande não só econômica como também política. No entanto, sua execução também facilitará o acesso a regiões de florestas, principalmente regiões localizadas nos bolsões de mogno do Pará, o que pode acarretar um efeito substancial no desmatamento da Amazônia.

Assim, elaborou-se um cenário onde a BR 163 está asfaltada e verificou-se o que este projeto impactaria na produção de soja na Amazônia. Os resultados podem ser observados nas Tabelas 34, 35 e 36 e na Figura 19.

Tabela 34. Produção e área plantada da soja considerando o asfaltamento da BR 163 , separado por estado.

\begin{tabular}{lrrrr}
\hline \multicolumn{5}{c}{ Asfaltamento da BR 163 } \\
\hline & Produção (t) & \multicolumn{1}{c}{$\%$} & \multicolumn{1}{c}{ Área(ha ) } & \multicolumn{1}{c}{$\%$} \\
\hline Mato Grosso & 49.166 .290 & $48,27 \%$ & 16.016 .840 & $44,85 \%$ \\
Pará & 18.422 .310 & $18,09 \%$ & 6.898 .045 & $19,32 \%$ \\
Maranhão & 14.310 .211 & $14,05 \%$ & 5.285 .630 & $14,80 \%$ \\
Tocantins & 12.167 .546 & $11,95 \%$ & 4.676 .035 & $13,09 \%$ \\
Rondônia & 2.819 .995 & $2,77 \%$ & 934.500 & $2,62 \%$ \\
Amazonas & 2.500 .289 & $2,45 \%$ & 922.460 & $2,58 \%$ \\
Roraima & 1.432 .370 & $1,41 \%$ & 595.700 & $1,67 \%$ \\
Amapá & 1.037 .875 & $1,02 \%$ & 382.375 & $1,07 \%$ \\
Acre & - & $0,00 \%$ & - & $0,00 \%$ \\
\hline AMAZÔNIA & 101.856 .886 & \multicolumn{3}{c}{35.711 .585} \\
\hline
\end{tabular}

Fonte: dados da pesquisa 

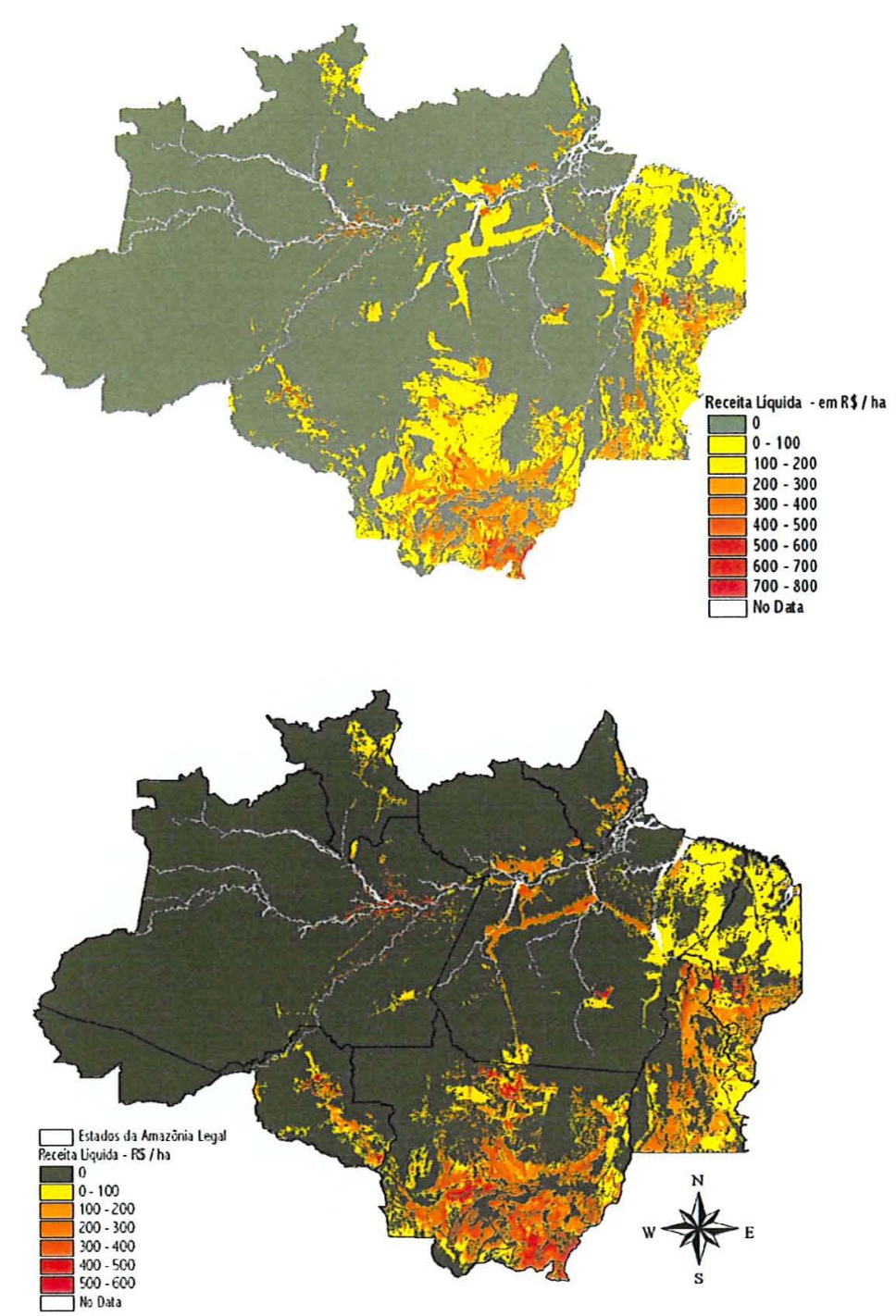

ASFALTAMENTO DA BR 163

\section{CENÁRIO BASE}

Figura 19. Comparação entre os mapas de asfaltamento da BR 163 e o cenário base.

Nota-se que a área plantada total passa a atingir mais de 35,7 milhões de ha, sendo que o estado do Mato Grosso continua predominante. O Pará, por outro lado, passa a ser o segundo maior produtor, com uma diferença mais significativa frente ao Maranhão e ao Tocantins. No cenário base estes três estados estavam mais próximos, enquanto os outros estados permaneceram com suas participações minoritárias na área plantada global.

Comparando-se os resultados deste cenário com os do cenário base (Tabela 35), observa-se claramente que o asfaltamento da BR 163 gera um importante crescimento da área plantada nos estados do Mato Grosso e Pará, por onde passa o seu traçado. O Amazonas é o único estado que sofre influência indireta do asfaltamento da BR 163, pois a Transamazônica percorre o sudeste do estado até se encontrar com a BR 163 na altura de Itaituba (PA). Assim, o asfaltamento reduz os custos de transporte desta região e favorece o plantio de soja. Os outros estados não sofrem influência significativa (na verdade as 
variações dos outros estados são decorrentes apenas de arredondamentos durante os cálculos).

Tabela 35. Variação na produção e área plantada da soja considerando o asfaltamento da BR 163 , separado por estado.

\begin{tabular}{lrcrc}
\hline \multicolumn{5}{c}{ Asfaltamento da BR 163 } \\
\hline & $\begin{array}{l}\text { Produção } \\
\text { (t) }\end{array}$ & $\begin{array}{c}\text { Varia- } \\
\text { ção }\end{array}$ & $\begin{array}{c}\text { Área } \\
\text { (ha })\end{array}$ & $\begin{array}{c}\text { Varia- } \\
\text { ção }\end{array}$ \\
\hline Mato Grosso & 12.553 .501 & $34,29 \%$ & 4.022 .410 & $33,54 \%$ \\
Tocantins & 92.064 & $0,76 \%$ & 1.855 & $0,04 \%$ \\
Maranhão & 138.538 & $0,98 \%$ & -455 & $-0,01 \%$ \\
Pará & 4.247 .163 & $29,96 \%$ & 1.557 .640 & $29,17 \%$ \\
Rondônia & $(672)$ & $-0,05 \%$ & $(315)$ & $-0,05 \%$ \\
Amazonas & 266.201 & $11,92 \%$ & 89.565 & $10,75 \%$ \\
Amapá & 29.731 & $0,78 \%$ & - & $0,00 \%$ \\
Roraima & 10.925 & $1,06 \%$ & & - \\
Acre & - & $0,00 \%$ & - & $0,00 \%$ \\
\hline AMAZÔNIA & 17.337 .451 & $20,27 \%$ & 5.670 .700 & $18,67 \%$ \\
\hline
\end{tabular}

Fonte: dados da pesquisa

No total, o asfaltamento da BR 163 gera um aumento de 18,67\% na área plantada com soja na Amazônia, com um adicional de 5,67 milhões de ha em relação ao cenário base. Ou seja, o asfaltamento desta rodovia realmente gera um impacto bastante significativo com relação ao avanço da fronteira agrícola na Amazônia.

Na Tabela 36 observa-se como este aumento na área plantada impacta os diferentes tipos de vegetações encontrados na Amazônia.

Tabela 36. Variação nos valores de produção e área plantada da soja considerando o asfaltamento da BR 163 , separado por tipo de vegetação anterior à soja.

\begin{tabular}{lrrrr}
\hline & \multicolumn{5}{c}{$\mathbf{- 1 0} \%$ para preços } \\
\hline Produção (t) & \multicolumn{1}{c}{ Variação } & Área ( ha ) & \multicolumn{1}{c}{ Variação } \\
\hline Flteradas & -2.084 .950 & $-4,12 \%$ & -854.245 & $-4,75 \%$ \\
Cerrado & 15.072 .503 & $428,46 \%$ & 5.043 .290 & $431,95 \%$ \\
\hline
\end{tabular}

Fonte: dados da pesquisa 
Como as regiões por onde a BR 163 passa são predominantemente cobertas por florestas, esta é a vegetação mais impactada pelo asfaltamento desta rodovia. No entanto, este impacto é extremamente alto, pois mais do que quadruplica a área de floresta, que é diretamente convertida para soja em relação ao cenário base (praticamente todo este incremento de área é feito sobre áreas de floresta). Vale ressaltar que a variação negativa das áreas já alteradas é resultado dos arredondamentos ocorridos no decorrer dos cálculos.

Portanto, nota-se que o incremento na área plantada com soja resultante deste projeto é bastante importante, aumentando em mais de $18 \%$ a área plantada total (cerca de 5,6 milhões de ha). No entanto, este aumento é predominante sobre a floresta Amazônica, o que demonstra que a execução desta obra deve vir acompanhada de um efetivo planejamento do uso da terra para que não gere depredações do patrimônio natural desta região.

\subsection{Cenário 6: Aumento de $10 \%$ nos fretes rodoviários}

Um outro parâmetro que sofre variações significativas é o frete rodoviário. Aumentos nos preços dos combustíveis, construção de novos pedágios, deterioração das rodovias e até a sazonalidade da produção agrícola afetam os preços dos fretes ao longo do tempo. Para a região estudada, o impacto dos fretes é muito mais significativo devido às grandes distâncias percorridas.

Assim, aumentou-se os fretes rodoviários do cenário base em 10\% a fim de observar o impacto dessa variação na área plantada e na produção. Este aumento nos fretes foi feito através da variação apenas dos coeficientes angulares da equação de fretes, sem variar os coeficientes lineares. Na Tabela 37 pode se observar os resultados deste novo cenário. 
Tabela 37. Produção e área plantada considerando um aumento de $10 \%$ nos fretes rodoviários, separado por estado.

\begin{tabular}{|c|c|c|c|c|}
\hline & \multicolumn{4}{|c|}{$+10 \%$ nos fretes agrícolas } \\
\hline & $\begin{array}{c}\text { Produção } \\
(\mathbf{t})\end{array}$ & $\%$ & $\begin{array}{l}\text { Área } \\
\text { (ha ) }\end{array}$ & $\%$ \\
\hline Mato Grosso & 34.322 .584 & $42,61 \%$ & 11.194 .400 & $39,52 \%$ \\
\hline Pará & 14.341 .542 & $17,80 \%$ & 5.336 .450 & $18,84 \%$ \\
\hline Maranhão & 14.307 .978 & $17,76 \%$ & 5.284 .090 & $18,65 \%$ \\
\hline Tocantins & 12.052 .935 & $14,96 \%$ & 4.622 .380 & $16,32 \%$ \\
\hline Rondônia & 3.441 .896 & $4,27 \%$ & 1.120 .945 & $3,96 \%$ \\
\hline Amazonas & 2.033 .153 & $2,52 \%$ & 749.490 & $2,65 \%$ \\
\hline Amapá & 48.260 & $0,06 \%$ & 17.780 & $0,06 \%$ \\
\hline Roraima & - & $0,00 \%$ & - & $0,00 \%$ \\
\hline Acre & - & $0,00 \%$ & - & $0,00 \%$ \\
\hline AMAZÔNIA & 80.548 .348 & & 28.325 .535 & \\
\hline
\end{tabular}

Fonte: dados da pesquisa

De uma forma geral, a mesma divisão dos estados pode ser observada neste cenário, com exceção de Roraima, onde o aumento no frete inviabilizou a produção. Isto se explica devido ao fato de Roraima estar destinando sua produção à Venezuela, percorrendo uma distância rodoviária bastante longa.

O Amapá também teve sua área plantada virtualmente reduzida a zero. Isto demonstra também que, apesar de estar próximo de um porto, as outras condições de produção, e principalmente o preço do frete, fazem com que esta região seja bastante sensível a uma variação nos custos de transportes

A variação deste cenário frente ao cenário base pode ser observada na Tabela 38 . 
Tabela 38. Variação na produção e na área plantada em relação ao cenário base considerando uma redução e um aumento de $10 \%$ nos fretes rodoviários, separado por estado.

\begin{tabular}{lcccc}
\hline \multicolumn{5}{c}{$+\mathbf{1 0} \%$ para fretes } \\
\hline & $\begin{array}{l}\text { Produção } \\
\text { (t) }\end{array}$ & Variação & Área & Variação \\
\hline Roraima & -1.433 .042 & $-100,00 \%$ & -596.015 & $-100,00 \%$ \\
Amapá & -978.690 & $-95,30 \%$ & -364.595 & $-95,35 \%$ \\
Rondônia & -370.289 & $-9,71 \%$ & -140.455 & $-11,13 \%$ \\
Amazonas & -200.935 & $-8,99 \%$ & -83.405 & $-10,01 \%$ \\
Mato Grosso & -2.290 .205 & $-6,26 \%$ & -800.030 & $-6,67 \%$ \\
Tocantins & -22.547 & $-0,19 \%$ & -51.800 & $-1,11 \%$ \\
Pará & 166.395 & $1,17 \%$ & -3.955 & $-0,07 \%$ \\
Maranhão & 136.305 & $0,96 \%$ & -1.995 & $-0,04 \%$ \\
Acre & - & $0,00 \%$ & - & $0,00 \%$ \\
\hline AMAZÔNIA & -4.993 .008 & $-5,84 \%$ & -2.042 .250 & $-6,73 \%$ \\
\hline
\end{tabular}

Fonte: dados da pesquisa

Nota-se que a variação deste cenário frente ao cenário base é significativa mas não tão intensa como nos outros cenários. Se for considerada a Amazônia como um todo, a área plantada se reduz apenas $6,73 \%$, com uma queda de pouco mais de 2 milhões de hectares. Nos outros cenários a variação gira em torno de $30 \%$. Considerando os estados, as maiores variações aconteceram nos estados de Roraima e Amapá, como observado anteriormente. 

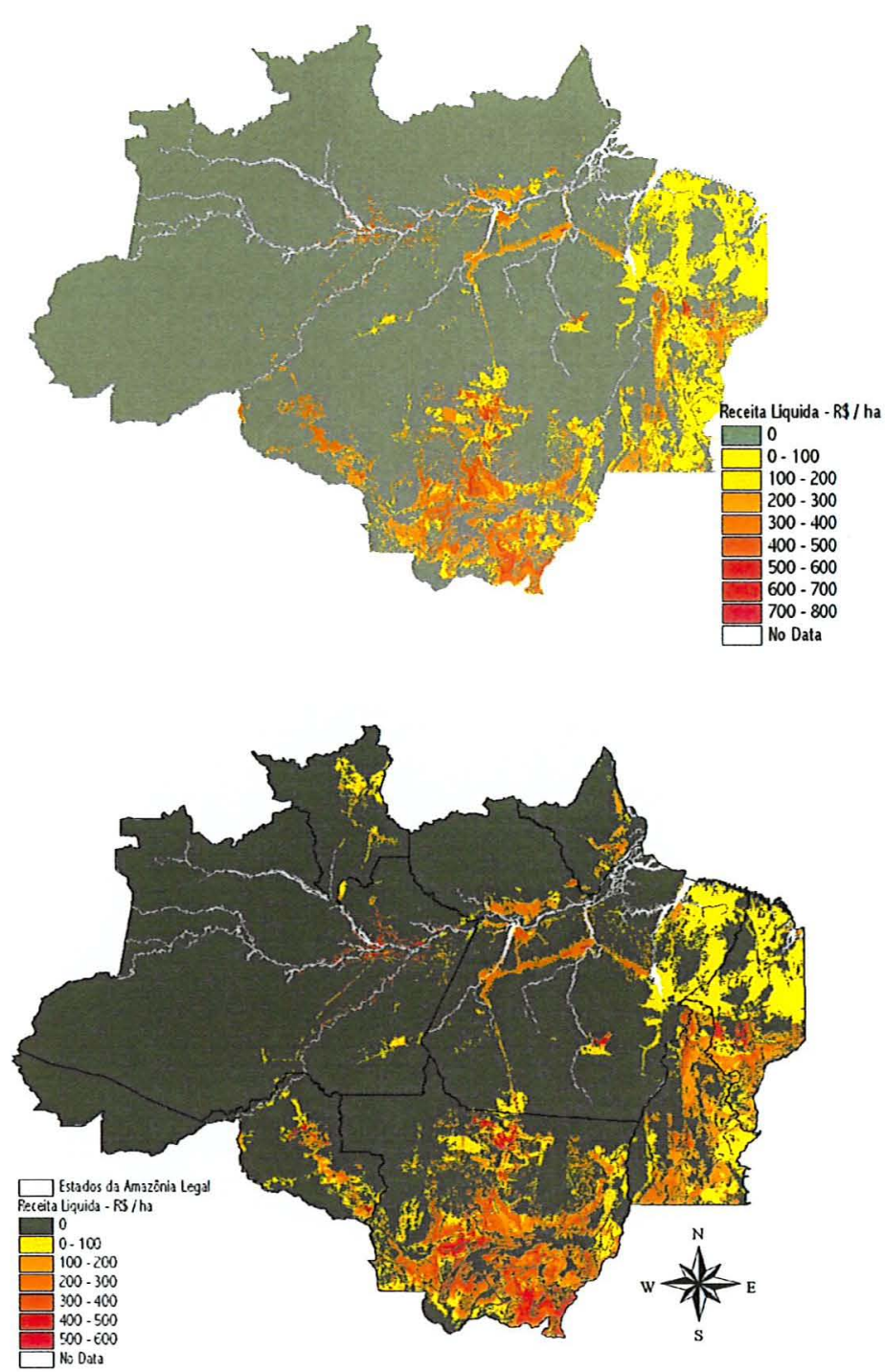

AUMENTO DE 10\%

NOS FRETES

RODOVIÁRIOS

\section{CENÁRIO BASE}

Figura 20. Comparação entre os mapas de variação dos custos de produção e o cenário base.

Os outros estados, por outro lado, observam reduções bem menores, não ultrapassando $12 \%$. No entanto, nota-se que os estados do leste sofrem menos o impacto da variação nos fretes que os estados à oeste. Isto pode ser explicado pelas maiores distâncias percorridas e pela precariedade das estradas dos estados à oeste, tornando os fretes naturalmente mais altos.

No caso dos estados do Pará e Maranhão, a variação de área é praticamente nula. No caso da produção, no entanto, há uma pequena variação positiva. Este resultado positivo é resultado de arredondamentos realizados durante os cálculos, o que gera essa incoerência, uma vez que a variação nos fretes reduz a receita líquida e só poderia reduzir ou manter a produção. No entanto, os valores de área plantada podem ser considerados corretos. 
Na Tabela 39, são apresentadas as variações na área e na produção, considerando a vegetação anterior à soja.

Tabela 39. Variação nos valores de produção e área plantada considerando um aumento de $10 \%$ nos fretes rodoviários, separado por tipo de vegetação anterior à soja.

\begin{tabular}{lcrlr}
\hline & \multicolumn{5}{c}{$\mathbf{+ 1 0} \%$ para fretes rodoviários } \\
\hline & $\begin{array}{l}\text { Produção } \\
(\mathbf{t})\end{array}$ & Variação & \multicolumn{1}{l}{ Área } & Variação \\
& -1.290 .548 & $-2,55 \%$ & -669.200 & $-3,72 \%$ \\
Alteradas & -223.201 & $-6,34 \%$ & -77.140 & $-6,61 \%$ \\
Cerrado & -3.502 .730 & $-11,17 \%$ & -1.304 .380 & $-11,64 \%$ \\
Floresta & -5.016 .479 & & -2.050 .720 & \\
AMAZÔNIA & & & & \\
\hline
\end{tabular}

Fonte: dados da pesquisa

Da mesma forma que os outros cenários, as áreas de floresta são as que mais são impactadas com a variação nos fretes. No entanto, a magnitude da variação é bem menor que nos outros cenários.

Uma modificação neste cenário é a variação maior nas áreas de cerrado que nas áreas já alteradas. A disposição apresentada na Tabela 38 não se observa nos cenários anteriores, apesar de ser mais lógica (uma vez que desmatar uma área de cerrado é mais caro que iniciar a produção em uma área já alterada). A magnitude da variação, da mesma forma, também é menor que nos cenários anteriores.

\subsection{Cenário 7: desconsideração das áreas com Areia Quartzosa}

As areias quartzosas são solos que, apesar de não serem em sua maioria inviáveis para a agricultura, apresentam um grande risco. O período de plantio nestes solos é bastante curto e a partir de qualquer variação climática mais significativa, principalmente com períodos de estiagem maiores, as culturas cultivadas neste tipo de solo são as mais afetadas.

Além disso, em algumas regiões, como o Jalapão, no estado do Tocantins, a presença de Areias Quartzosas relaciona-se praticamente com regiões desérticas, onde a agricultura é inviável. 
Assim, estes solos tendem a não ser utilizados para o plantio de grãos, mesmo sendo observados alguns plantios, principalmente em Rondônia e Mato Grosso. Por isto, foi feita esta simulação desconsiderando este tipo de solo para que possamos observar o quanto isto pode influenciar nos resultados finais obtidos por este modelo.

Tabela 40. Redução nos valores de produção e área plantada por estado desconsiderando os solos Areia Quartzosa e variação com relação ao cenário base

\begin{tabular}{lcccc}
\hline & \multicolumn{2}{c}{$\begin{array}{c}\text { Redução desconsiderando as } \\
\text { Areias Quartzosas }\end{array}$} & \multicolumn{2}{c}{$\begin{array}{c}\text { Variação em relação ao } \\
\text { cenário base }\end{array}$} \\
\hline \multicolumn{1}{c}{ Estado } & $\begin{array}{c}\text { Produção } \\
(\mathbf{t})\end{array}$ & $\begin{array}{c}\text { Área } \\
(\text { ha })\end{array}$ & Produção & Área \\
& 3.867 .360 & 1.611 .400 & $-32,027 \%$ & $-34,474 \%$ \\
\hline Tocantins & 6.236 .710 & 2.325 .225 & $-17,034 \%$ & $-19,386 \%$ \\
Mato Grosso & 160.104 & 66.710 & $-11,172 \%$ & $-11,193 \%$ \\
Roraima & 341.133 & 134.085 & $-8,948 \%$ & $-10,630 \%$ \\
Rondônia & 945.672 & 394.030 & $-6,673 \%$ & $-7,454 \%$ \\
Maranhão & 663.174 & 275.310 & $-4,678 \%$ & $-5,155 \%$ \\
Pará & 8.904 & 3.710 & $-0,399 \%$ & $-0,445 \%$ \\
Amazonas & - & - & $0,000 \%$ & $0,000 \%$ \\
Amaṕn & - & - & $0,000 \%$ & $0,000 \%$ \\
Acre & 12.223 .057 & 4.810 .470 & $-14,289 \%$ & $-15,841 \%$ \\
\hline AMAZÔNIA & & &
\end{tabular}

Fonte: dados da pesquisa

A perda de área para a produção de grãos decorrente da exclusão das Areias Quartzosas é de 15,84\%, totalizando 4.810 .470 ha. Esta redução é apenas das áreas de Areia Quartzosa que estão na solução do cenário base e não de toda a área com este tipo de solos na Amazônia.

Os estados mais prejudicados pela presença de Areais Quartzosas são o Tocantins e o Mato Grosso, não coincidentemente dois dos mais interessantes em termos de receita líquida. Em termos relativos, o primeiro estado tem mais de um terço de sua área viável com Areia Quartzosa, o que confirma as limitações comentadas anteriormente. O Mato Grosso, no entanto, é maior em termos absolutos, chegando a uma área de 2.325.225 ha. Os outros estados, apesar de relativamente apresentarem alguma importância, em termos absolutos não ultrapassam 400.000 ha com Areia Quartzosa. 


\subsection{Cenário 8: aumento da capacidade da Ferrovia Carajás e das hidrovias}

Como a limitação de carga das hidrovias e ferrovias afetam significativamente a área de influência dos corredores, simulou-se o o cenário a partir do aumento da capacidade nestas vias. Foram aumentadas as capacidades da Ferrovia do Carajás (20 milhões t / ano e 30 milhões $\mathrm{t} /$ ano), da hidrovia do Tapajós ( 3 milhões $\mathrm{t} / \mathrm{ano}$ ), da hidrovia do Tocantins ( 2 milhões de $\mathrm{t} / \mathrm{ano}$ ), da hidrovia do Araguaia ( 2 milhões de $\mathrm{t} / \mathrm{ano}$ ), da hidrovia do Tocantins abaixo de Marabá (4 milhões $\mathrm{t} /$ ano) e da hidrovia do Madeira ( 3 milhões $\mathrm{t} /$ ano).

Os valores atribuídos à ferrovia foram baseados na possibilidade de duplicação da ferrovia, o que permitiria o transporte de 30 milhões de toneladas. Já para as hidrovias, foram atribuídos valores arbitrários com o intuito de simular o comportamento do modelo frente a estas alterações.

Na Tabela 41 são apresentadas as variações ocorridas nos resultados, decorrentes da variação da capacidade de carga das vias.

Tabela 41. Variação da produção e área por corredor em relação ao cenário base, considerando o aumento na capacidade de transporte da ferrovia do Carajás e das hidrovias.

\begin{tabular}{lrrrrrrr}
\hline & \multicolumn{2}{c}{ Carajás } & \multicolumn{2}{c}{ Carajás } & \multicolumn{2}{c}{ Hidrovias } \\
& 20 milhões t / ano & \multicolumn{2}{c}{ 30 milhões t / ano } & & \\
\hline \multicolumn{1}{c}{ Corredores } & Produção & Área & Produção & Área & Produção & Área \\
\hline Caracas & $0,00 \%$ & $0,00 \%$ & $0,00 \%$ & $0,00 \%$ & $0,00 \%$ & $0,00 \%$ \\
Itacoatiara & $0,00 \%$ & $0,00 \%$ & $0,00 \%$ & $0,00 \%$ & $130,90 \%$ & $118,16 \%$ \\
Paranaguá & $0,00 \%$ & $0,00 \%$ & $0,00 \%$ & $0,00 \%$ & $0,00 \%$ & $0,00 \%$ \\
Santana & $0,00 \%$ & $0,00 \%$ & $0,00 \%$ & $0,00 \%$ & $0,00 \%$ & $0,00 \%$ \\
Santarém & $0,00 \%$ & $0,00 \%$ & $0,00 \%$ & $0,00 \%$ & $0,00 \%$ & $0,00 \%$ \\
São Luís & $0,00 \%$ & $0,00 \%$ & $0,00 \%$ & $0,00 \%$ & $0,00 \%$ & $0,00 \%$ \\
Vila do Conde & $0,00 \%$ & $0,00 \%$ & $0,00 \%$ & $0,00 \%$ & $0,00 \%$ & $0,00 \%$ \\
Vilhena & $0,00 \%$ & $0,00 \%$ & $0,00 \%$ & $0,00 \%$ & $0,00 \%$ & $0,00 \%$ \\
\hline
\end{tabular}

Fonte: dados da pesquisa

O aumento da capacidade de carga na ferrovia Carajás não gera nenhum efeito em termos de aumento de área ou produção na solução final. Isto, apesar de parecer uma 
incongruência, justifica-se pelo fato desta ferrovia estar em uma região bem servida por rodovias, sendo que a produção que supera o limite é levada até São Luís por caminhões. É interessante notar que apesar da mudança de modal, o transporte rodoviário não inviabiliza a produção de soja nestas áreas.

No caso das hidrovias, o efeito gerado é o mesmo, com exceção de Itacoatiara. Como já foi comentado anteriormente, este corredor é dependente da hidrovia pois não tem acesso rodoviário viável. Com isso, o aumento de sua capacidade de 1,3 milhão t / ano para 3 milhões $t$ / ano gera um aumento de $130,90 \%$ na produção escoada por este corredor (que corresponde ao aumento da capacidade de transporte), aumentando sua área de influência em $118,16 \%$. Esta variação menos que proporcional da área se deve ao fato das produtividades serem maiores que $1 \mathrm{t} / \mathrm{ha}$.

Estes dados também demonstram que, apesar das hidrovias serem importantes para o efeito direto da soja no desmatamento da floresta Amazônica devido ao seu baixo frete, o aumento da capacidade de transporte das hidrovias deveria incorporar novas áreas de floresta, o que não se observa neste cenário. Mesmo no caso de Itacoatiara (onde a capacidade de transporte é o fator limitante), as áreas incorporadas são ou cerrados ou áreas já desmatadas. O que se observa, na verdade, é interação de três fatores: preço do frete, distância até o porto e produtividade. As áreas onde a soja tem um efeito direto estão próximas às hidrovias (frete barato), mas quanto mais longe dos portos, maior deve ser a produtividade da região para que seja viável o desmatamento.

Mesmo não implicando alterações em área, o aumento da capacidade operacional destas vias tem um efeito importante sobre a receita líquida de algumas regiões. Na Tabela 40 pode-se observar a área afetada pelas simulações realizadas.

Tabela 42. Área total com receita líquida alterada devido ao aumento na capacidade de transporte das vias.

\begin{tabular}{cccc}
\hline & $\begin{array}{c}\text { Carajás } \\
\text { 20 milhões t } / \text { ano }\end{array}$ & $\begin{array}{c}\text { Carajás } \\
\mathbf{3 0} \text { milhões t / ano }\end{array}$ & Hidrovias \\
\hline $\begin{array}{c}\text { Áreas com alteração } \\
\text { nas receitas líquidas } \\
\text { (ha) }\end{array}$ & 3.614 .030 & 6.873 .965 & 7.015 .190 \\
\hline
\end{tabular}

Fonte: dados da pesquisa 
Estas alterações na receita líquida se devem, basicamente, à substituição do modal utilizado. Enquanto nos cenários com limites menores estas áreas utilizavam a rodovia para transportar sua soja, com o aumento da capacidade elas passam a utilizar os modais mais baratos. Assim, nota-se por esta tabela que uma área significativa terá suas receitas líquidas reduzidas com o aumento da capacidade das ferrovias e hidrovias. No caso da ferrovia dos Carajás, a área afetada se concentra no corredor que leva a São Luís (MA), ou seja, tem um efeito localizado na área de influência desta ferrovia. Por outro lado, as áreas afetadas pelo aumento na capacidade das hidrovias estão dispersas por toda a região amazônica. Estes resultados são esperados, pois uma boa parte desta região sofre a influência de alguma hidrovia.

A seguir são apresentados nas Tabelas 43, 44, 45 e 46 os resultados dos principais cenários deste trabalho, a fim de permitir uma melhor comparação entre eles.

Tabela 43. Área plantada com soja em cada estado da Amazônia Legal segundo os resultados do cenário base e dos cenários pessimistas.

\begin{tabular}{lcrcrcrcr}
\hline Estado & $\begin{array}{c}\text { Cenário } \\
\text { base } \\
\text { (ha) }\end{array}$ & $\begin{array}{c}\text { Redução } \\
\text { de 10\% } \\
\text { nos preços }\end{array}$ & $\begin{array}{c}\text { Aumento } \\
\text { de 10\% } \\
\text { nos custos } \\
\text { de prod. }\end{array}$ & $\begin{array}{c}\text { Redução } \\
\text { de 10\% } \\
\text { nas } \\
\text { produtiv. }\end{array}$ & $\%$ \\
\hline Mato Grosso & 11.994 .430 & $39 \%$ & 8.941 .380 & $49,40 \%$ & 9.917 .705 & $47,10 \%$ & 9.762 .725 & $48,23 \%$ \\
Pará & 5.340 .405 & $18 \%$ & 2.036 .440 & $11,25 \%$ & 3.034 .990 & $14,41 \%$ & 2.617 .755 & $12,93 \%$ \\
Maranhão & 5.286 .085 & $17 \%$ & 1.787 .380 & $9,88 \%$ & 2.039 .310 & $9,69 \%$ & 1.926 .400 & $9,52 \%$ \\
Tocantins & 4.674 .180 & $15 \%$ & 3.573 .745 & $19,75 \%$ & 3.927 .560 & $18,65 \%$ & 3.852 .485 & $19,03 \%$ \\
Rondônia & 1.261 .400 & $4 \%$ & 684.075 & $3,78 \%$ & 981.505 & $4,66 \%$ & 952.875 & $4,71 \%$ \\
Amazonas & 832.895 & $3 \%$ & 553.525 & $3,06 \%$ & 620.270 & $2,95 \%$ & 602.525 & $2,98 \%$ \\
Roraima & 596.015 & $2 \%$ & 200.445 & $1,11 \%$ & 210.210 & $1,00 \%$ & 323.190 & $1,60 \%$ \\
Amapá & 382.375 & $1 \%$ & 321.265 & $1,78 \%$ & 324.030 & $1,54 \%$ & 203.210 & $1,00 \%$ \\
Acre & - & $0 \%$ & - & $0,00 \%$ & - & $0,00 \%$ & - & $0,00 \%$ \\
\hline AMAZÔNIA & 30.367 .785 & $100 \%$ & 18.098 .255 & & 21.055 .580 & & 20.241 .165 & \\
\hline
\end{tabular}

Fonte: dados da pesquisa

Nota-se que os estados do Mato Grosso e do Tocantins apresentam um maior número de regiões com risco econômico menor, pois em todos os cenários pessimistas suas participações aumentam significativamente. Ambos os estados são um pouco mais sensíveis a aumentos nos custos de produção que nos demais cenários. O Pará e o Maranhão apresentam reduções significativas em suas participações em todos os cenários pessimistas, sendo o Pará mais sensível a reduções nas produtividades e o Maranhão a 
reduções de preços e custos de produção. Os demais estados mantêm praticamente inalteradas suas participações em todos os cenários.

É importante notar que os dados apresentados na Tabela 43 mostram as áreas com menores riscos econômicos para a instalação da cultura soja, pois mesmo com situações adversas de preço, custo ou produtividade, elas ainda são viáveis economicamente. Isto significa que estas áreas têm maiores chances de produzirem soja que as demais devido à sua atratividade econômica (para visualizar a localização destas áreas, vide Figuras 16, 17 e 18).

Tabela 44. Área plantada com soja em cada estado da Amazônia Legal segundo os resultados do cenário base e dos cenários otimistas.

\begin{tabular}{lcrcrcrcr}
\hline Estado & $\begin{array}{c}\text { Cenário } \\
\text { base } \\
\text { (ha) }\end{array}$ & $\begin{array}{c}\text { Aumento } \\
\text { de 10\% no } \\
\text { preços }\end{array}$ & & $\begin{array}{c}\text { Redução } \\
\text { de 10\% } \\
\text { nos custos } \\
\text { de prod. }\end{array}$ & $\begin{array}{c}\text { Aumento } \\
\text { de 10\% } \\
\text { nas }\end{array}$ & $\%$ \\
\hline Mato Grosso & 11.994 .430 & $39 \%$ & 16.793 .385 & $39,86 \%$ & 16.096 .395 & $36,80 \%$ & 15.821 .750 & $39,44 \%$ \\
Pará & 5.340 .405 & $18 \%$ & 8.786 .050 & $20,85 \%$ & 8.648 .465 & $19,77 \%$ & 8.259 .160 & $20,59 \%$ \\
Maranhão & 5.286 .085 & $17 \%$ & 6.189 .015 & $14,69 \%$ & 6.174 .945 & $15,04 \%$ & 6.119 .575 & $15,26 \%$ \\
Tocantins & 4.674 .180 & $15 \%$ & 5.059 .670 & $12,01 \%$ & 5.055 .925 & $11,56 \%$ & 5.017 .635 & $12,51 \%$ \\
Rondônia & 1.261 .400 & $4 \%$ & 1.815 .765 & $4,31 \%$ & 1.771 .070 & $4,05 \%$ & 1.758 .505 & $4,38 \%$ \\
Amazonas & 832.895 & $3 \%$ & 1.442 .665 & $3,42 \%$ & 1.247 .470 & $2,85 \%$ & 1.238 .405 & $3,08 \%$ \\
Roraima & 596.015 & $2 \%$ & 649.775 & $1,54 \%$ & 648.970 & $1,48 \%$ & 646.695 & $1,61 \%$ \\
Amapá & 382.375 & $1 \%$ & 1.396 .080 & $3,31 \%$ & 1.407 .840 & $3,22 \%$ & 1.285 .830 & $3,21 \%$ \\
Acre & - & $0 \%$ & - & $0,00 \%$ & - & $0,00 \%$ & - & $0,00 \%$ \\
\hline AMAZÔNIA & 30.367 .785 & $100 \%$ & 42.132 .405 & & 43.741 .950 & & 40.147 .555 & \\
\hline
\end{tabular}

Fonte: dados da pesquisa

Com relação aos cenários otimistas, a participação relativa dos estados permanece semelhante ao cenário base, com exceção do estado do Amapá, que apresenta um crescimento substancial de sua área plantada.

Tabela 45. Área plantada com soja em cada vegetação da Amazônia Legal segundo os resultados do cenário base e dos cenários otimistas.

\begin{tabular}{lcrcccccc}
\hline Estado & $\begin{array}{c}\text { Cenário } \\
\text { base } \\
\text { (ha) }\end{array}$ & $\begin{array}{c}\text { Aumento } \\
\text { de 10\% no } \\
\text { preços }\end{array}$ & $\begin{array}{c}\text { Redução } \\
\text { de 10\% } \\
\text { nos custos } \\
\text { de prod. }\end{array}$ & $\begin{array}{c}\text { Aumento } \\
\text { de 10\% } \\
\text { nas } \\
\text { produtiv. }\end{array}$ & $\%$ \\
\hline Alterada & 17.994 .305 & $59 \%$ & 21.059 .675 & $49,98 \%$ & 20.994 .785 & $51,14 \%$ & 20.929 .930 & $52,13 \%$ \\
Cerrado & 11.205 .985 & $37 \%$ & 13.169 .240 & $31,26 \%$ & 12.853 .435 & $31,31 \%$ & 12.677 .140 & $31,58 \%$ \\
Floresta & 1.167 .565 & $4 \%$ & 7.903 .560 & $18,76 \%$ & 7.202 .930 & $17,55 \%$ & 6.540 .555 & $16,29 \%$ \\
\hline AMAZÔNIA & 30.367 .855 & $100 \%$ & 42.132 .475 & & 41.051 .150 & & 40.147 .625 \\
\hline
\end{tabular}

Fonte: dados da pesquisa 
Tabela 46. Área plantada com soja sobre cada tipo de vegetação da Amazônia Legal segundo os resultados do cenário base e dos cenários pessimistas.

\begin{tabular}{lcrcrcrcr}
\hline \multicolumn{1}{c}{ Estado } & $\begin{array}{c}\text { Cenário } \\
\text { base } \\
\text { (ha) }\end{array}$ & $\begin{array}{c}\text { Redução } \\
\text { de 10\% no } \\
\text { preços }\end{array}$ & $\begin{array}{c}\text { Aumento } \\
\text { de 10\% } \\
\text { nos custos } \\
\text { de prod. }\end{array}$ & $\begin{array}{c}\text { Redução } \\
\text { de 10\% } \\
\text { nas } \\
\text { produtiv. }\end{array}$ & $\%$ \\
\hline Alterada & 11.994 .430 & $39 \%$ & 10.468 .815 & $57,84 \%$ & 12.068 .280 & $57,32 \%$ & 11.539 .360 & $57,01 \%$ \\
Cerrado & 5.340 .405 & $18 \%$ & 7.538 .650 & $41,65 \%$ & 8.802 .500 & $41,81 \%$ & 8.546 .545 & $42,22 \%$ \\
Floresta & 5.286 .085 & $17 \%$ & 90.860 & $0,50 \%$ & 184.870 & $0,88 \%$ & 155.330 & $0,77 \%$ \\
\hline AMAZÔNIA & 30.367 .785 & $100 \%$ & 18.098 .325 & & 21.055 .650 & & 20.241 .235 & \\
\hline
\end{tabular}

Fonte: dados da pesquisa

Em ambas as Tabelas 45 e 46 é possível observar que o tipo de vegetação mais sensível a qualquer variação são as florestas. Para os cenários otimistas, a área desmatada para o plantio de soja chega a quintuplicar, enquanto os outros tipos de cobertura vegetal não apresentam um crescimento tão expressivo. Isto demonstra que os novos projetos de infra-estrutura de transporte facilitam o acesso às áreas de florestas, permitindo que em situações específicas seja economicamente interessante o desmatamento para o plantio de soja.

Nos cenários pessimistas, as florestas também reduzem significativamente suas áreas desmatadas. Neste caso, o alto custo de desmatamento torna o avanço da soja sobre a floresta mais sensível às variações econômicas. 


\section{CONCLUSÕES}

A soja já está presente na Amazônia Legal há mais de 15 anos, mas somente nos últimos anos é que se iniciou uma discussão mais contundente sobre o tema. Isto se deve ao fato de atualmente a soja estar ameaçando áreas de floresta amazônica, diferentemente dos anos anteriores, quando a soja utilizava predominantemente áreas de pastagens e cerrados, que têm um apelo muito menor junto à opinião pública. Além disso, esta discussão vem acompanhando os debates em torno dos projetos de melhoria da infra-estrutura de transportes para a região, que devem promover o desenvolvimento de áreas atualmente pouco desenvolvidas, mas com um potencial de impacto significativo sobre o meio ambiente e sobre as comunidades.

Estes projetos de infra-estrutura alteram substancialmente a geografia de produção e o fluxo de escoamento da soja, na medida em que se direcionam para portos ao norte, invertendo o caminho natural para os portos das regiões Sul e Sudeste. Além disso, utilizam a multimodalidade como princípio, o que reduz as ineficiências do transporte unimodal rodoviário que ainda predomina no país.

Como o mercado da soja é bastante afetado pelo custo de transporte, tanto como item de custo de produção como na formação dos preços, estes novos projetos geram oportunidades totalmente novas para as empresas deste setor.

A soja é uma cultura que necessita de grande áreas para a produção e de grandes quantidades de capital e conhecimento técnico, o que tende a excluir a população amazônica deste desenvolvimento, além de gerar um processo de concentração fundiária e de renda de pessoas de outras regiões do país. Os problemas sociais decorrentes deste processo são muito bem conhecidos nas regiões Sul e Sudeste.

Assim, é necessário um planejamento bem estruturado da região para que todas as possibilidades de desenvolvimento, bem como todos os anseios da sociedade, sejam considerados e este processo não seja excludente nem demasiadamente impactante. Este planejamento deve ser executado pelas instituições governamentais, que necessariamente 
devem consultar a população envolvida e a sociedade como um todo, para que este processo seja válido e sólido e possa almejar o desenvolvimento sustentável.

Este trabalho teve como objetivo subsidiar o processo de planejamento, fornecendo informações para uma análise mais criteriosa a respeito dos impactos da soja na Amazônia, considerando a conclusão dos projetos de infra-estrutura de transportes previstos nos programas governamentais "Brasil em Ação" e "Avança Brasil", além de outros projetos da iniciativa privada.

O que os dados deste trabalho mostram é que a soja tende a atingir uma área bastante significativa na Amazônia, principalmente no entorno da malha de transportes. Os novos projetos de infra-estrutura tendem a estimular demasiadamente a produção de soja, inclusive viabilizando o desmatamento de floresta amazônica em algumas regiões. Isto é especialmente verdade nos entornos dos portos de Itacoatiara e Santarém e no norte do Mato Grosso.

Apesar disto, o desmatamento direto de floresta amazônica causado pela introdução da soja não deve ser maior que $4 \%$ de toda a área plantada na Amazônia Legal, principalmente devido aos altos custos de desmatamento. A soja tende a ocupar principalmente as áreas já desmatadas (pecuária e agricultura de corte e queima) e em segundo lugar desmatar as áreas de cerrado, o que mantém o processo tradicional de expansão da fronteira agrícola brasileira.

No entanto, vale lembrar que estes resultados foram obtidos com os dados de desmatamento de 1991 e desta data até hoje mais de 13 milhões de hectares foram desmatados (principalmente florestas e vegetação de transição), principalmente em Rondônia, no norte do Mato Grosso e no Pará. Assim, estes resultados podem ser diferentes, na medida em que estas áreas têm maior probabilidade de serem incorporadas à solução. Por outro lado, elas também permitem um acesso mais barato às florestas mais longínquas, o que pode permitir que outras áreas sejam desmatadas. A força resultante deste processo é indefinida, mas a magnitude das áreas desmatadas diretamente pela soja não deve ser muito diferente dos $4 \%$ obtidos por este modelo. 
Com relação aos corredores, os mais importantes portos em termos de escoamento da produção serão São Luís e Paranaguá (através da Ferronorte). Estes dois corredores abrangem uma área bem servida por rodovias asfaltadas e têm como eixo central uma ferrovia (com maior capacidade de transporte que as hidrovias). Santarém e Vila do Conde também têm importância significativa pois, além das hidrovias que compõem seu eixo central, também são servidas por uma infra-estrutura rodoviária, que por sinal estão em precárias condições. Os outros corredores têm importância bem menor como escoadores da soja da Amazônia. O principal motivo é o limite de transporte pelas hidrovias, que acaba sendo a principal restrição no caso de Itacoatiara.

Já quanto aos estados, o Mato Grosso se consolidará como o principal produtor de soja da região e talvez do Brasil, com uma diferença bastante significativa para os outros estados. Num segundo bloco, Pará, Maranhão e Tocantins têm participações bastante semelhantes e compõem uma faixa praticamente contínua a leste da região Amazônica. $\mathrm{O}$ Pará também apresenta uma importante região produtora no eixo ao longo da BR 163, mas com menor importância se comparado ao leste do estado. Os outros estados terão importância bem menos significativa na produção de soja.

A BR 163, por sinal, tende a ter um impacto bastante grande no avanço da soja sobre a floresta, pois o seu asfaltamento possibilitará o acesso a áreas pouco desenvolvidas do norte do Mato Grosso e sudoeste do Pará.

A variação climática deve ser um parâmetro importante a ser observado em $42,65 \%$ da área viável com soja, sendo $19,21 \%$ por problemas de seca em alguns anos e 23,44\% por excesso de chuvas. Desta última, $1,46 \%$ são inviáveis para o plantio, enquanto para $21,98 \%$ ainda existem dúvidas quanto à viabilidade técnica de produção. Mesmo assim, a maior parte das áreas tendem a ocupar regiões de climas mais propícios. No entanto, o avanço para o norte deve dar acesso a regiões cada vez mais complicadas em termos de clima, principalmente devido ao excesso de chuvas. Assim, é necessário que as pesquisas atualmente em andamento sobre a viabilidade técnica e econômica da soja nestas áreas sejam finalizadas rapidamente para a verificação das reais possibilidades do avanço da soja nestas regiões. Caso seja inviável no longo prazo (apesar de já existirem áreas com altas pluviosidades sendo utilizadas), uma barreira natural será imposta a estas áreas. No entanto, 
caso se confirme a viabilidade ou se desenvolva novas tecnologias que permitam o acesso às áreas mais úmidas, será necessário um planejamento criterioso do uso da terra, pois começa-se a acessar áreas bastante frágeis em termos ambientais com uma rica biodiversidade e uma população que depende dos recursos da floresta.

Com relação à variação dos valores dos principais parâmetros deste modelo (preços, custos de produção, produtividades e fretes), o comportamento dos cenários é bastante parecido, com a redução de área plantada nas regiões leste do Pará, norte do Mato Grosso, Amapá e Maranhão nos cenários pessimistas e aumentos no norte do Mato Grosso, sul do Pará, Amapá e Roraima nos cenários otimistas. De uma forma geral, a variação destes cenários gira em torno de $30 \%$ de aumento ou redução de área. O único cenário que foge a esta regra é a variação nos preços dos fretes, onde o impacto geral é bem menor, mas atinge substancialmente Roraima e o Amapá.

Assim, os principais fatores que afetam a expansão da soja na Amazônia podem ser listados a seguir:

- proximidade de portos;

- altas produtividades;

- $\quad$ áreas sem floresta;

- áreas próximas às hidrovias ou às ferrovias;

- áreas bem servidas de rodovias;

Nota-se, portanto, que se a evolução tradicional da fronteira agrícola continuar a ser observada na Amazônia, a soja tende a ganhar cada vez mais espaço, pois a expansão da soja estimula o avanço da pecuária sobre a floresta. Este avanço gera áreas desmatadas que futuramente poderão ser utilizadas pela soja como novas áreas de produção, alimentando o processo indefinidamente.

Para que este processo seja equilibrado, os governos federal e estaduais deveriam priorizar um amplo planejamento do uso da terra na região Amazônica, com vistas a um equilíbrio entre os objetivos econômicos, sociais e ambientais da sociedade. Assim, algumas ações poderiam ser tomadas para que este processo fosse ordenado, tais como: 
- demarcação de áreas de conservação em regiões de grande interesse ambiental ou comunitário (grande biodiversidade, comunidades tradicionais ou indígenas, exploração tradicional de espécies florestais, etc.), visando conter o avanço sobre as áreas mais vulneráveis. Neste ponto, merecem especial atenção as regiões oeste do Pará, norte do Mato Grosso e sul do Amazonas, principalmente na área de influência da BR 163 , onde o asfaltamento da rodovia deve aumentar substancialmente o interesse pelas regiões de seu entorno, onde se localizam muitas comunidades tradicionais e áreas de interesse ambiental (nestas regiões encontram-se as principais ocorrências de mogno no Brasil);

- estímulo à valorização dos recursos florestais, com a utilização e processamento de óleos e essências, frutas, produtos químicos extraídos de plantas e exploração madeireira sob manejo, gerando uma alternativa econômica ao proprietário da área, reduzindo o interesse para a conversão da floresta em pasto ou agricultura. Neste sentido, novas linhas de financiamento para a pequena indústria de produtos florestais e o estímulo à diferenciação dos produtos (através de selos de origem, certificação ambiental, dentre outras), além de programas de capacitação de mão de obra, campanhas de conscientização junto aos mercados consumidores e parcerias com empresas interessadas em produtos de origem florestal, podem ser estratégias viáveis para a agregação de valor de produtos que são atualmente desperdiçados e, com isso, não geram valor para as florestas;

- os investimentos em infra-estrutura de transportes deveriam se concentrar em regiões onde o interesse pela agricultura fosse bastante claro. Assim, regiões como o norte do Mato Grosso, Tocantins, Maranhão e Rondônia devem receber especial atenção, com o desenvolvimento de uma intensa malha que permita o melhor escoamento da produção. Por outro lado, regiões como o sul do Amazonas, Acre, Amapá, e o centro do Pará deveriam ser menos priorizadas. 
- maiores investimentos em pesquisa deveriam ser feitos para a identificação do real impacto da soja na Amazônia e de sua viabilidade técnica em regiões de alta pluviosidade;

- todos os financiamentos relacionados ao desenvolvimento da agricultura na região Amazônica deveriam ser balizados segundo os dados levantados nos trabalhos de zoneamento do uso da terra e nas pesquisas agrônomicas para a região, fomentando apenas as operações que fossem sustentáveis.

Este trabalho apresentou algumas limitações com relação à coleta de dados, conforme já citados ao longo do texto. As principais estão relacionadas com a condição de relevo da Amazônia, já que não foi possível obter mapas adequados para a incorporação deste parâmetro no modelo. Assim, algumas regiões apresentadas na solução podem ser inviáveis tecnicamente por conta de problemas de declividades muito elevadas, o que inviabilizaria, ou pelo menos reduziria a atratividade, destas áreas para a produção de soja.

Além disso, não foram consideradas explicitamente as áreas de reserva legal, que foram bastante debatidas durante o primeiro semestre de $2000 \mathrm{com}$ a reforma do Código Florestal Brasileiro. A ampliação da área legal permitida para a agricultura na Amazônia (tanto para cerrados como para florestas), conforme se propôs neste debate, pode aumentar a área desmatada em regiões onde não há limite de transporte. No entanto, para regiões com restrição de carga, como Itacoatiara por exemplo, um menor número de região produtoras devem fornecer a mesma produção que atinge o limite do corredor (vale lembrar que para este modelo assumiu-se que apenas $35 \%$ da área seria utilizada com soja). No entanto, outros aspectos, como recursos hídricos e biodiversidade também devem ser observados nesta discussão.

Outra limitação foram os dados de desmatamento que deixaram de incorporar mais de 13 milhões de hectares, segundo INPE (2000), e que possivelmente poderiam estar incorporados na solução deste modelo.

Como sugestão de novos trabalhos, aconselha-se que se analise, através de um modelo de equilíbrio geral, como a produção destas áreas da Amazônia impactará a 
sojicultura brasileira e mundial, verificando se ela é mais competitiva que as demais regiões do país e que os outros países competidores.

Além disso, seria interessante analisar o impacto do avanço da sojicultura na expansão da pecuária e da extração madeireira, permitindo quantificar este impacto e identificar formas de minimizar este processo.

Um outro trabalho interessante seria a simulação de possíveis zoneamentos baseados em critérios sócio-econômicos e ambientais, a fim de se maximizar o crescimento econômico com um mínimo de impacto sócio-ambiental.

Por fim, seria interessante um trabalho que atualizasse os dados deste cenário e incorporasse novas simulações, como a variação da área de reserva legal, a incorporação de impostos de circulação de mercadorias, dentre outras análises que fossem relevantes para a sojicultura. 


\section{REFERÊNCIA BIBLIOGRÁFICA}

AGUIAR, D. Formação de preços na indústria brasileira de soja - 1982/1989. Piracicaba, 1990. 138 p. Dissertação (M.S.) - Escola Superior de Agricultura "Luiz de Queiroz", Universidade de São Paulo.

AGUIAR, D. A indústria de esmagamento de soja no Brasil: mudança estrutural, conduta e alguns indicadores de desempenho. Revista de Economia e Sociologia Rural, v.32, n.1 e 2, p.23-46, 1994.

ASSOCIAÇÃO BRASILEIRA DAS INDÚSTRIAS DE ÓLEOS VEGETAIS - ABIOVE. Capacidade de processamento de soja nos estados brasileiros. http:Ilwww.abiove.com.br\ (20/06/1999).

ARAÚJO, A. S. Distância e renda locacional da terra: uma aplicação do modelo de von Thünen. Viçosa, 1994. 67 p. Dissertação (M.S.) - Universidade Federal de Viçosa.

ARIMA, E.; UHL, C. Pecuária na Amazônia oriental: desempenho atual e perspectivas futuras. Belém: Imazon, 1996. 44 p. (Série Amazônia, n.1)

BARLOWE, R. Land resource economics: the political economy of rural and urban land resource use. 5.ed. Englewood Cliffs: Prentice-Hall, 1965. 585 p.

BEGUR, S. V.; MILLER, D. M.; WEAVER, J. R. An integrated spatial DSS for scheduling and routing home-health-care nurses. Interfaces, v.27, n.4, p.35-48, June/Aug. 1997.

BOUMAN, B. A. M.; JANSEN, H. G. P.; SCHIPPER, R. A.; NIEUWENHUYSE, A.; HENGSDIJK, H.; BOUMA, J. A framework for integrated biophysical and economic land use analysis at different scales. Agriculture Ecosystem \& Environment, v.75, n.1-2, p.55-73, July 1999.

BRAGA, A. R. S.; SPERA, S. T.; CORREIA, J. R. Potencialidade agrícola na região do corredor de transporte multimodal Centro-Norte. Revista de Política Agrícola, v.6, n.1, p.11-16, 1997.

BRASIL. Ministério do Planejamento. Plano Plurianual 2000 - 2003. httpllwww.mpo.gov.br\ (17/11/1999).

BRASIL. Ministério dos Transportes. Programa "Brasil em Ação. http:llwww.transportes.gov.br\(28/06/1999).

BROOKE, A.; KENDRICK, D.; MEERAUS, A. GAMS: a user's guide, Release 2.25. Local ?: The Scientific Press, 1992. 289 p. 
BRUSVEN, M. A.; WALKER, D. J.; PAINTER, K. M.; BIGGAM, R. C. Ecologicaleconomic assessment of a sediment-producing stream behind lower-granite dam on the lower Snake River, USA. Regulated Rivers - Research \& Management, v.10, n.2-4, p.373-87, Aug.1995.

BULHÕES, R. Análise da competição entre os portos de Paranaguá e Santos para a movimentação de soja: aplicação de um modelo de equilíbrio espacial. Piracicaba, 1998. 108 p. Dissertação (M.S.) - Escola Superior de Agricultura "Luiz de Queiroz", Universidade de São Paulo.

CAFFAGNI, L. C. Curso de especialização em mercado de commodities agropecuárias, 1999.15 p. (material didático do curso... qual curso e local ?)

CAIXETA FILHO, J. V. Transporte e logística no sistema agroindustrial. In: BACHA, C. J. C. (org.) Noções de economia e administração agroindustrial. Piracicaba: ESALQ. Departamento de Economia e Sociologia Rural, 1998. p.254-281. (Série Didática, n.122)

CAIXETA FILHO, J. V.; SILVA, N. D. V.; GAMEIRO, A. H.; LOPES, R. L.; GALVANI, P. R. C.; MARTIGNON, L. M.; MARQUES, R. W. C. Competitividade do agribusiness: a questão do transporte em um contexto logístico (compact disc). In: COMPETITIVIDADE DO AGRIBUSINESS BRASILEIRO. São Paulo: IPEA/FIA/PENSA, 1998.

CAO, B. Y.; SUN, M. H.; Mac LEOD, C. Applying GIS and combinatorial optimization to fiber deployment plans. Journal of Heuristics, v.5, n.4, p.385-482, Dec. 1999.

CUNHA, A. S. Uma avaliação da sustentabilidade da agricultura nos cerrados. Brasília: IPEA, 1994. 204 p. (Estudos de Política Agrícola, n.11)

DUNN, JR., E. S. The equilibrium of land-use patterns in agriculture. In: DEAN, R. D. et al. Spatial economic theory. New York: The Free Press, 1970. p.233-49.

DUTRA, E. S. Análise do padrão de ocupação da fronteira agrícola de Rondônia. São Paulo, 1993. 198 p. Dissertação (M.S.) - Faculdade de Economia, Administração e Contabilidade, Universidade de São Paulo.

EMPRESA BRASILEIRA DE PLANEJAMENTO DE TRANSPORTES - GEIPOT. Anuário Estatístico, 1998. http:llwww.geipot.gov.br\(19/06/1999).

EMPRESA BRASILEIRA DE PLANEJAMENTO DE TRANSPORTES - GEIPOT. Corredores estratégicos de desenvolvimento. Brasília: Ministério dos Transportes, 1999. $307 \mathrm{p}$.

FERREIRA, C. M. C. As teorias de localização e a organização espacial da economia. In: HADDAD, P. R.; FERREIRA, C. M. C.; BOISER, S.; ANDRADE, T. A. Economia 
regional: teorias e métodos de análise. Fortaleza: Banco do Nordeste do Brasil, 1989. cap.2, p.67-206.

FERREIRA, L. R.; BURNQUIST, H. L.; AGUIAR, D. R. D. Infra-estrutura, comercialização e competitividade da agricultura brasileira. Brasília: IPEA, 1993. 63 p. (Texto para Discussão, n. 318)

FIGUEIREDO, H. P. Transporte marítimo na comercialização do grão do cerrado no mercado asiático. CVRD - revista, v.6, n.21, p.3-10, set.1985.

FNP CONSULTORIA \& COMÉRCIO. Agrianual 1999: Anuário da Agricultura Brasileira. São Paulo, 1999. 521 p.

FNP CONSULTORIA \& COMÉRCIO. Agrianual 2000: Anuário da Agricultura Brasileira. São Paulo, 2000. 526 p.

GAZETA MERCANTIL. BALANÇO ANUAL 98 : Pará. São Paulo, v.3, n.3, 1998. 66p.

GEORGE, S. M.; BABU, P. R.; KHANNA, P. Neural network model for consequence analysis of developmental proposal. Journal of Urban Planning and Development, v.123, n.4, p.81-101, dez.1997.

GUIMARÃES NETO, L. Dinâmica regional no Brasil. Brasília, 1997. ? p. (Versão preliminar para discussão no IPEA por extenso).

GUIMARÃES, A. L.; UHL, C. O transporte rural na Amazônia Oriental: limites, opções e oportunidades. Belém: Imazon, 1998. 28 p. (Série Amazônia, n.12)

HANINK, D. M. Evaluation of wilderness in a spatial context. Growth and Change, v.26, n.3, p.425-441, 1995. / Resumo /

HELFAND, S. M.; REZENDE, G. C. Mudanças na distribuição espacial da produção de grãos, aves e suínos no Brasil: o papel do Centro-Oeste. Brasília: IPEA, 1998. 38p. (Texto para Discussão, n.611)

HSU, S. K. The agroindustry: a neglected aspect of the location theory of manufacturing. Journal of Regional Science, v.37, n.2, p.259-274, 1997.

INSTITUTO NACIONAL DE PESQUISAS ESPACIAIS - INPE. Monitoramento da Floresta Amazônica Brasileira. http://www.inpe.br/. (19/04/2000).

INSTITUTO DO HOMEM E MEIO AMBIENTE DA AMAZÔNIA. O Pará no século XXI: oportunidades para o desenvolvimento sustentável. Belém: Imazon, 1998.83 p.

JONES, D. W.; O'NEILL, R. V. Development policies, rural land use, and tropical deforestation. Regional Science and Urban Economics, v.24, p.753-771, 1994. 
JONES, D. W.; O'NEILL, R. V. Land-use in the presence of an atmosphere externality, with and without corrective taxes. Journal of Regional Science, v.33, n.4, p.457-480, 1993. / Resumo /

JORNAL A GAZETA. Custos e riscos aumentam com precariedade. In: Clipping Famato. http:llwww.famato.org.brl (09/03/1999).

JORNAL A GAZETA. Início de safra. In: Clipping Famato. http:llwww.famato.org.brl $(09 / 03 / 1999)$.

JORNAL A GAZETA. Hidrovia passa a operar em MT. In: Clipping Famato. http:llwww.famato.org.brl (09/03/1999).

JORNAL A GAZETA. Campo Novo decreta estado de emergência. In: Clipping Famato. http:Ilwww.famato.org.brl (17/03/1999).

JORNAL A GAZETA. Grande economia no frete. In: Clipping Famato. http:Ilwww.famato.org.br\ (26/05/1999).

KELLERMAN, A. Agricultural location theory, 2: relaxation of assumptions and applications. Environment and Planning A, v.21, p.1427-1448, 1989.

LANE, T. G. ArcView - Spatial Analyst - Using the ArcView Spatial Analyst. ESRI, $1991,147 \mathrm{p}$.

LAZZARINI, S. G. NUNES, R. Competitividade do sistema agroindustrial da soja. In: COMPETITIVIDADE DO AGRIBUSINESS BRASILEIRO, (compact disc). São Paulo: IPEA/FIA/PENSA, 1998.

LÍCIO, A.; CORBUCCI, R. A agricultura e os corredores de transporte multimodais. Revista de Política Agrícola, v.5, n.2, p.22-36, 1996.

MACMILLAN, W. D. Risk and agricultural land-use - a reformulation of the portfoliotheoretic approach to the analysis of a von Thünen economy. Geographical Analysis, v.24, n.2, p.142-158, 1992./ Resumo /

MARGARIDO, M. A.; SOUSA, E. L. L. Formação de preços da soja no Brasil. In: CONGRESSO BRASILEIRO DE ECONOMIA E SOCIOLOGIA RURAL, Poços de Caldas, 1998. / Resumo em cd-rom do Congresso Brasileiro de Economia e Sociologia Rural /

MARQUES, P. V.; SOUSA, E. L. L. de. Cenários dos sistemas agroindustriais de grãos no Brasil e novas formas de comercialização. In: CONGRESSO BRASILEIRO DE ECONOMIA E SOCIOLOGIA RURAL, Poços de Caldas, 1998. / Resumo em cd-rom do Congresso Brasileiro de Economia e Sociologia Rural / 
MARQUES, R. W. C.; CAIXETA FILHO, J. V. Ferronorte e transporte de grãos. Preços Agrícolas, v.12, n.140, p.12-17, jun. 1998.

NEVES, L. C. Margens de comercialização e elasticidades de transmissão de preços na indústria de esmagamento de soja. Piracicaba, 1993. 90 p. Dissertação (M.S.) - Escola Superior de Agricultura "Luiz de Queiroz", Universidade de São Paulo.

NEVO, A.; GARCIA, L. Spatial optimization of wildlife habitat. Ecological Modelling, v.91, n.1-3, p.271-281, nov.1996.

O'KELLY, M.; BRYAN, D. Agricultural location theory: von Thünen's contribution to economic geography. Progress in Human Geography, v.20, n.4, p.457-475, 1996.

OLIVETTI, M. P. A.; CAMARGO, A. M. M. P. Evolução da composição agrícola no Brasil e principais regiões produtoras, 1968-89. Agricultura em São Paulo, v.39, n.1, p.155-177, 1992.

PAVAN, R. C. Brasil: na onda verde do progresso. Brasília: Imprensa Oficial do Estado S. A., 1997. 2v.

PINTO, T. Vale transportará milho ao Nordeste. Gazeta Mercantil, 05-07 nov.1999. p.B20.

QIU, W.; WATKINS, G. A.; SOBOLIK, C. J.; SHEARER, S. A. A feasibility stydy of direct injection for variable rate of herbicide application. Transactions of the ASAE, v.41, n.2, p.291-299, Mar./April 1998.

REIS, E. J.; MARGULIS, S. Perspectivas econômicas do desflorestamento da Amazônia. Brasília: IPEA, 1991. 47 p. (Texto para Discussão, n. 215)

ROESSING, A. C. Situação mundial das oleaginosas. Informe Econômico CNPSo, v.3 n.1, p.5-56, 1997.

ROESSING, A. C. Situação mundial das oleaginosas. Informe Econômico CNPSo, v.4 n.1, p.5-35, 1998.

SISTEMA DE INFORMAÇÕES DE FRETES DE CARGAS AGRÍCOLAS. Informe SIFRECA. Piracicaba: ESALQ/CEPEA, vários números, 1997-1999.

SMITH, J.; WINOGRAD, M.; GALLOPIN, G.; PACHICO, D. Dynamics of the agricultural frontier in the Amazon and savannas of Brazil: analyzing the impact of policy and technology. Environment Modeling and Assessment, n.3, p.31-46, 1998.

SOUSA, I. S. F. Condicionantes da modernização da soja no Brasil. Revista de Economia e Sociologia Rural, v.28, n.2, p.175-212, abr./jun. 1990. 
STOMS, D. M.; BORCHERT, M. I.; MORITZ, M. A.; DAVIS, F. W.; CHURCH, R. L. A systematic process for selecting representative research in natural areas. Natural Areas Journal, v.18, n.4, p.338-349, Oct.1998.

STONE, S. W. Using a geographic information system for applied policy analysis: the case of logging in the Eastern Amazon. Ecological Economics, v.? n.27, p.43-61, 1998.

SUGAI, Y.; TEIXEIRA FILHO, A. R.; VIEIRA, R. C.; OLIVEIRA, A. J. Projeção da demanda regional de grãos no Brasil 1996-2005. Revista de Política Agrícola, v.7, n.2, p.28-40, 1998.

SOMBROEK, W. G. Annual rainfall and dry-season strength in the Amazon region and their environmental consequences. Local ?, nov.1999. 16p. / mimeo /

TAHER, S. A.; LABADIE, J. W. Optimal design of water-distribution networks with GIS. Journal of Water Resources, Planning and Management, v.122, n.4, p.301-311, JulyAug. 1996.

TRATADO DE COOPERAÇÃO AMAZÔNICA. Desenvolvimento e conservação na Amazônia brasileira: inventário e análise de projetos. Lima, 1996. 247 p.

VADAS, R. G.; GARCIA, L. A.; LABADIE, J. W. A methodology for water quantity and quality assessment for wetland development. Water Science and Technology, v.31, n.8, p.293-300, 1995.

VERÍSSIMO, A.; BARRETO, P.; MATTOS, M.; TARIFA, R.; UHL, C. Logging impacts and prospects for sustainable forest management in an old Amazonian frontier: the case of Paragominas. Forest Ecology and Management, v.55, p.196-199, 1995.

WALSH, S. J.; PAGE, P. H.; GESLER, W. M. Normative models and healthcare planning: network-based simulations within a geographic information system environment. Health Services Research, v.32, n.2, p.243-260, June 1997.

WANG, F.; GULDMANN, J. M. A spatial equilibrium model for region size, urbanization ration, and rural structure. Environment and Planning A, v.29, p.429-441, 1997.

XIANG, W. N. A GIS MMP-based coordination model and its application to distributed environmental-planning. Environment and Planning B - Planning and Design, v.20, n.2, p.195-220, Mar.1993. 


\section{APÊNDICE 1}

OPORTUNIDADES DE INVESTIMENTO PÚBLICO E PRIVADO EM INFRAESTRUTURA DE TRANSPORTE RELACIONADAS COM A EXPANSÃO DA PRODUÇÃO DE GRÃOS NA AMAZÔNIA PREVISTAS PELO PLANO PLURIANUAL PARA O PERÍODO DE 2000 - 2007 


\section{OPORTUNIDADES DE INVESTIMENTO PÚBLICO E PRIVADO EM INFRA- ESTRUTURA DE TRANSPORTE RELACIONADAS COM A EXPANSÃO DA PRODUÇÃO DE GRÃOS NA AMAZÔNIA PREVISTAS PELO PLANO PLURIANUAL PARA O PERÍODO DE 2000 - 2007}

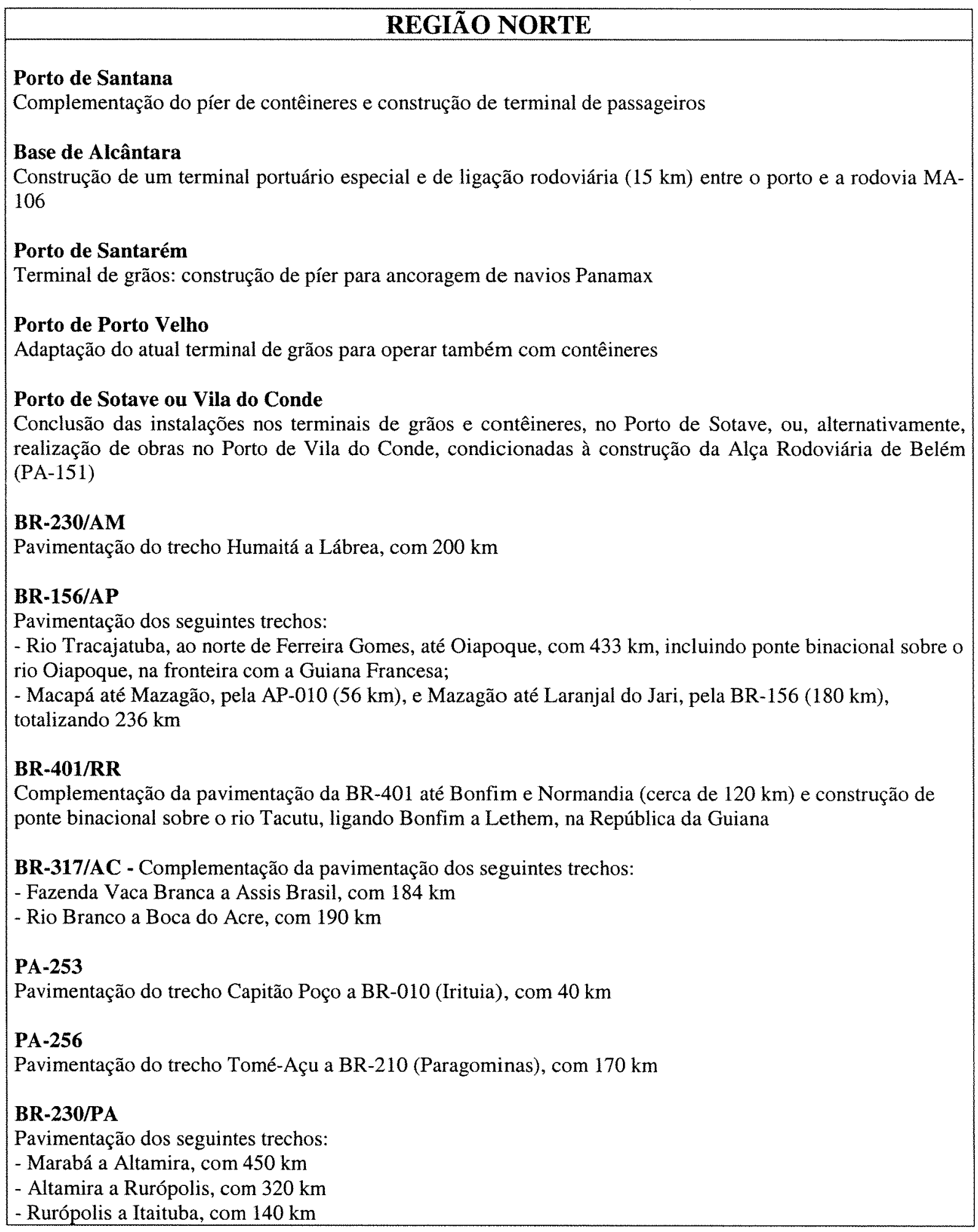


BR-163/PA - Pavimentação dos seguintes trechos:

- Santarém a Rurópolis, com $200 \mathrm{~km}$

- Matupá-MT a Itaituba-PA, com 807 km (projeto alternativo à Hidrovia Teles Pires-Tapajós)

BR-364/AC - Pavimentação do trecho Sena Madureira a Cruzeiro do Sul, com $490 \mathrm{~km}$

BR-319/AM - Pavimentação da rodovia Manaus a Porto Velho, trecho Humaitá a Careiro da Várzea com cerca de $730 \mathrm{~km}$

\section{REGIÃO NORDESTE}

\section{Hidrovia do Parnaíba}

Conclusão do sistema de 2 eclusas e canal de interligação na barragem de Boa Esperança e obras complementares na hidrovia do rio Parnaíba, trecho Santa Filomena a Teresina

\section{Terminais de Grãos em Teresina e Santa Filomena}

Construção de dois terminais para transbordo e armazenagem, um rodohidroviário e outro hidroferroviário, em Santa Filomena/PI e Teresina

\section{Hidrovia do São Francisco}

Complementação das obras previstas no Programa Brasil em Ação

\section{Malha Ferroviária Centro-Leste, entre Candeias e Salvador Pinto}

Construção de variante entre Candeias e Salvador Pinto, com $76 \mathrm{~km}$ de linha única, $2 \mathrm{~km}$ de pontes e $4 \mathrm{~km}$ de passagens laterais

\section{Malha Ferroviária Centro-Leste}

Restauração dos seguintes trechos:

- $577 \mathrm{~km}$ entre Iaçu e Monte Azul

- 103 km entre Mapele e São Francisco

- 451 km entre São Francisco e Juazeiro

\section{Ferrovia Transnordestina}

Construção de novas linhas:

- 350 km, de Petrolina a Missão Velha/PE, passando por Salgueiro

- 179 km entre Crateús e Piquet Carneiro/CE

Malha Ferroviária do Nordeste, entre São Luís e Teresina

Recondicionamento de $442 \mathrm{~km}$ de linha simples, leito, sistema de sinalização e comunicação, além de construção de ligação (no km 59) para transbordo entre trens de bitola larga e estreita

Malha Ferroviária do Nordeste, entre Salgueiro e Recife e entre Teresina, Altos e Crateús

Restauração de linhas existentes entre Salgueiro e Recife $(595 \mathrm{~km})$ e entre Teresina, Altos e Crateús (296 $\mathrm{km})$, com extensão total de $891 \mathrm{~km}$

\section{BR-020/PI}

Complementação da pavimentação do trecho Picos a São Raimundo Nonato

\section{BR-324/PI}

Pavimentação do trecho Eliseu Martins a Urussuí, com 165 km

BR-135/BA

Pavimentação de $70 \mathrm{~km}$, de Barreiras a Gilbués 


\section{REGIÃO CENTRO-OESTE}

\section{Dragagem do Rio das Mortes}

Dragagem e derrocamento no trecho Nova Xavantina a São Félix do Araguaia

\section{Eclusa na UHE Lajeado}

Construção de eclusa para transposição da UHE Lajeado

\section{Transposição da Hidrelétrica de Tucuruí}

Construção de um conjunto de 2 eclusas, interligadas por um canal intermediário

\section{Transposição das Corredeiras de Santa Isabel do Araguaia}

Construção de canal com extensão de 14 km e desnível de $13 \mathrm{~m}$, para evitar as corredeiras de Santa Isabel, no Rio Araguaia

\section{Hidrovia Teles Pires-Juruena-Tapajós}

Implantação de $1.043 \mathrm{~km}$ de hidrovia, incluindo canal dotado de eclusa no trecho de $23 \mathrm{~km}$ entre as cachoeiras de São Luís do Tapajós e Buburé, além de derrocamento, dragagem e balizamento

\section{Hidrovia Paraguai-Paraná}

Dragagem no Canal Tamengo e apoio à navegação no trecho Cáceres a Corumbá

\section{Porto Hidroviário de Cáceres}

Adequação e ampliação do porto

\section{Terminais no Rio Araguaia}

Construção de terminais hidroviários em Luís Alves (GO); São Félix do Araguaia (MT); Santa Terezinha (GO)

\section{Terminais no Rio Tocantins}

Construção de terminais hidroviários em Miracema do Tocantins (TO), Pedro Afonso (TO), Carolina (MA), Porto Franco (MA) e Peixe (TO)

\section{Terminais de Soja}

Construção de terminais de soja em Aruanã e Nova Xavantina

\section{Terminais de Soja e Cimento}

Construção de terminais de soja e cimento em Xambioá

\section{Terminal de Grãos em Cachoeira Rasteira}

Terminal para transbordo e armazenagem em Cachoeira Rasteira

\section{Ferrovia Norte-Sul}

Construção de nova ferrovia Goiânia a Estreito, com 1.466 km

\section{Ferrovia Xambioá a Estreito}

Construção de nova ferrovia, com $165 \mathrm{~km}$

\section{Malha Ferroviária Oeste}

Recondicionamento e instalação de sinalização em $1.300 \mathrm{~km}$ de linha simples, entre Corumbá e Bauru, construção de $6 \mathrm{~km}$ de pontes e $24 \mathrm{~km}$ de linhas laterais. Inclui construção de variantes para eliminar transposições urbanas no Mato Grosso do Sul 


\section{BR-226/TO}

Restauração em 72 km de pista simples na rodovia existente entre Wanderlândia e Estreito

\section{BR-010/MA}

Restauração em $118 \mathrm{~km}$ de pista simples na rodovia existente de Estreito a Imperatriz

\section{TO-296}

Rodovia de $170 \mathrm{~km}$ conectando Paranã/TO à BR-153/TO (Belém-Brasília), altura de Alvorada/TO. Trecho a ser pavimentado: Paranã-São Salvador, de $55 \mathrm{~km}$ em leito natural; trecho a ser construído: São SalvadorAlvorada, de $115 \mathrm{~km}$

\section{BR-158/MT}

Construção de $423 \mathrm{~km}$ de rodovia em pista simples na diretriz da rota precária existente, de Ribeirão Cascalheira à divisa MT/PA

\section{BR-060/MT}

Pavimentação de $150 \mathrm{~km}$ da rodovia, alimentadora da Ferronorte, de Chapadão do Sul a Serranópolis

\section{BR-330/MA-006/PI-254}

Complementação da pavimentação de $373 \mathrm{~km}$, de Balsas a Gilbués. Do total, $219 \mathrm{~km}$ estão concluídos, restando trecho de $154 \mathrm{~km}$ entre a divisa MA/PI e Gilbués (PI-254)

\section{Rodovias Alimentadoras de Terminais nos Rios Araguaia e das Mortes}

Pavimentação de $318 \mathrm{~km}$ nas seguintes rodovias: GO-244/BR-080, entre São Miguel do Araguaia e Luís Alves, $51 \mathrm{~km}$

BR-242, de São Félix do Araguaia à BR-158, 114 km

MT-431, entre Sta. Terezinha e MT-413, $28 \mathrm{~km}$

MT-413, entre MT-431 e MT-432, $45 \mathrm{~km}$

MT-432, entre MT-413 e Destilaria Gameleira, $80 \mathrm{~km}$

Construção da BR-251, de Nova Xavantina a Paranatinga, $130 \mathrm{~km}$

\section{BR-153/GO e BR-365/MG}

Duplicação de $240 \mathrm{~km}$ da BR-153, no trecho Aparecida de Goiânia a Monte Alegre de Minas (entroncamento BR-365) e de 100 km da BR-365 no trecho Monte Alegre de Minas a Uberlândia

\section{BR-060/DF-GO}

Duplicação de $128 \mathrm{~km}$ de rodovia no trecho de Taguatinga/DF a Anápolis/GO

MT-170

Pavimentação de $555 \mathrm{~km}$ de rodovia no trecho de Campo Novo do Parecis a Juína e Cotriguaçu

\section{MT-319}

Pavimentação de $245 \mathrm{~km}$ de rodovia, de Vilhena a Juína

MT-235

Pavimentação de $256 \mathrm{~km}$ de rodovia e construção de $600 \mathrm{~m}$ de novas pontes, da MT-70 à BR-174 Trecho Comodoro a Campo Novo dos Parecis

\section{BR-364/MT}

Duplicação de 210 km de rodovia, de Cuiabá a Rondonópolis, e construção de variante de $20 \mathrm{~km}$ na Serra de São Vicente

\section{Várias Estradas Agrícolas ao Norte e Leste de Mato Grosso}

Pavimentação de $1.023 \mathrm{~km}$ nas seguintes rodovias:

MT-208, trecho Alta Floresta-Nova Bandeirantes: 272 km (incluindo acessos para Apiacás e Paranaita) 
BR-163 trecho Santa Helena-Matupá: $71 \mathrm{~km}$

MT-423 trecho Entr. BR-163-Marcelândia: 114 km

MT-442 trecho Sinop-Santa Carmem: $33 \mathrm{~km}$

MT-160 trecho Apiacás-Cachoeira Rasteira: 150 km; MT-338/208, trecho Juara-Nova Bandeirantes: 211 km

BR-267/MS

Restauração no trecho de 175 km, de Rio Brilhante (MS) à BR-419/060

BR-163/MT

Melhoria e recuperação de 430 km da BR-163/MT, de Cuiabá a Sinop (km 520 ao km 950)

Várias Rodovias no Oeste: BR-174/MT, BR-364/MT, BR-364/RO

Melhoramento de vários trechos da BR-174/MT ( $\mathrm{km} 8$ ao 520; Cáceres-Comodoro), da BR-364/MT (km 0 ao 121; Alto Araguaia-Rondonópolis) e BR-364/RO ( $\mathrm{km} 0$ ao 14, km 36 ao 78, km 90 ao 109 e km 480 ao 525; Vilhena-Jamari)

MT-220/MT-325

Pavimentação de $53 \mathrm{~km}$ da rodovia MT-220 e $56 \mathrm{~km}$ da rodovia MT-325, do Posto Fiscal Juruena a Juara

MS-178

Pavimentação de 45 km da MS-178 no trecho Bonito-MS ao entroncamento BR-267

MT-070

Pavimentação de 86 km da MT-070 no trecho Cáceres/MT a San Matias na Bolívia 
APÊNDICE 2

PRESSUPOSIÇÕES E DADOS UTILIZADOS NO CENÁRIO BASE 


\section{Infra-estrutura}

- Todas as principais hidrovias e ferrovias planejadas nos Programas Plurianuais do Governo Federal em operação;

- Hidrovia do Tocantins chegando até Peixe (TO);

- Hidrovia do Capim chegando até as imediações de Paragominas (PA);

- Ferronorte chegando até Cuiabá (MT);

- Ferrovia Norte-Sul chegando até Estreito (MA);

- De todas as rodovias planejadas para serem asfaltadas, semente as BR 163 e BR 242 foram consideradas em seu leito natural;

- Portos de exportação considerados: São Luís (MA), Vila do Conde (PA), Santana (AP), Santarém (PA), Itacoatiara (AM) e Paranaguá (PR);

- Fontes de calcário consideradas: Barcarena (PA), Palestina do Pará (PA), Itaituba (PA), Monte Alegre (PA), Medicilândia (PA), Riachão (MA), Guaraí (TO), Formoso do Araguaia (TO), Natividade (TO), Cocalinho (MT), Nobres (MT), Tangará da Serra (MT), Cáceres (MT), Pimenta Bueno (RO) e Itacoatiara (AM);

- Fontes de adubo consideradas: Imperatriz (MA), Itacoatiara (AM) (importando de Israel) e Paranaguá (PR);

\section{Limites para o transporte e esmagamento}

- Limite de carga de 1,3 milhão de toneladas para a hidrovia do Madeira e 1 milhão de toneladas para as demais (exceção do rio Amazonas, que não foi considerado nenhum limite de carga);

- Portos, ferrovias e rodovias sem limite de carga;

- Capacidade de esmagamento das indústrias de Rondonópolis totalizando $670.000 \mathrm{t} /$ ano (3.350 t / dia por 200 dias / ano) - vide Tabela 9;

- Capacidade de esmagamento das indústrias de Cuiabá totalizando $1.040 .000 \mathrm{t} /$ ano (5.200 t / dia por 200 dias / ano) - vide Tabela 9;

- Capacidade de esmagamento da indústria de Vilhena totalizando $60.000 \mathrm{t} /$ ano (300 t / dia por 200 dias / ano) - segundo dados de campo;

- Capacidade de esmagamento da indústria de Sorriso totalizando $60.000 \mathrm{t} /$ ano (300 t / dia por 200 dias / ano) - segundo dados de campo; 
- Capacidade de esmagamento da indústria de Sinop totalizando $120.000 \mathrm{t} /$ ano (600 t / dia por 200 dias / ano) - segundo dados de campo;

\section{Preços da soja}

- Preços pagos pela soja nos portos iguais a $\mathrm{R} \$ 20,00$ / sc. (semelhante ao preço pago em Paranaguá);

- Para Paranaguá, considerou-se um custo de $\mathrm{R} \$ 34,00$ / t de frete ferroviário até Alto Taquari (MT);

- Variação dos preços a partir dos portos e indústrias dado apenas pela subtração dos custos de transporte;

\section{$\underline{\text { Preços do calcário }}$}

- Para jazidas ainda não exploradas ou exploradas apenas para cimento o preço utilizado foi $\mathrm{R} \$ 16,00 / \mathrm{t}$;

- Preços das outras jazidas (coletados em campo):

- Itacoatiara - R $\$ 20,00 / \mathrm{t}$

- Guaraí - R\$16,00/t

- Riachão - R\$16,00 / t

- Formoso do Araguaia - $\mathrm{R} \$ 16,00 / \mathrm{t}$

- Nobres - R\$7,00/t

- Tangará da Serra - R\$11,00/t

- Cocalinho-R $\$ 16,00 / \mathrm{t}$

- Cáceres - R\$16,00/t

- Pimenta Bueno - R\$16,00/t

- Variação dos preços a partir das jazidas é dado apenas pela adição dos custos de transporte;

\section{Preços do adubo}

- Preços das praças fornecedoras (estimados de acordo com os dados coletados em campo):

- Itacoatiara - R $\$ 410,50 / \mathrm{t}$

- Paranaguá - $\mathrm{R} \$ 388,00 / \mathrm{t}$ (considerando $\mathrm{R} \$ 34,00 / \mathrm{t}$ o custo do frete ferroviário de Paranaguá a Alto Taquari - MT - através da Ferronorte)

- Imperatriz - R\$425,00/t

- Variação dos preços a partir dos fornecedores é dado apenas pela adição dos custos de transporte;

Preco dos fretes 
- Fretes calculados através de equações regionalizadas obtidas por regressão dos dados coletados em campo, dados únicos coletados em campo ou informações secundárias;

- Custo de transbordo - $\mathrm{R} \$ 2,00 / \mathrm{t}$;

- Custo de balsa-R $\$ 0,90 / \mathrm{t}$;

- Equações e valores para :

- rodovias asfaltadas do MT, RO, AC e AM frete $=$ distância $* 0,05380-9,5955$

- rodovias asfaltadas do TO, MA e PA frete $=$ distância $* 0,03500+3,1484$

- rodovias asfaltadas de $\mathrm{RR}-\mathrm{R} \$ 0,04667 / \mathrm{t} * \mathrm{~km}$

- rodovias não asfaltadas - $\mathrm{R} \$ 0,0650 / \mathrm{t} * \mathrm{~km}$

- estradas vicinais - $\mathrm{R} \$ 0,5600 / \mathrm{t} * \mathrm{~km}$

- hidrovia Tocantins - $\mathrm{R} \$ 0,02340 / \mathrm{t} * \mathrm{~km}$

- hidrovia do Araguaia frete $=$ distância $* 0,02190+0,9530$

- hidrovia do Madeira, Tocantins após Marabá, Tapajós e Amazonas $\mathrm{R} \$ 0,01749 / \mathrm{t} * \mathrm{~km}$

- ferrovias Norte-Sul, Carajás e Jari frete $=$ distância $* 0,01890+4,3490$

- Ferronorte $-\mathrm{R} \$ 0,02620 / \mathrm{t} * \mathrm{~km}$

\section{Produção}

- Calcário sendo aplicado a cada 5 anos;

- Retorno ao investimento em desmatamento de 5 anos;

- Custos operacionais e necessidades de calcário e adubo levantados em campo para a safra 99/00;

- Custos de administração e pós-colheita considerados homogêneos e iguais à média dos valores dos municípios da Amazônia Legal coletados por FNP (2000), sendo este valor igual a $\mathrm{R} \$ 91,11$ / ha

\section{Utilização da área}

- $35 \%$ da área total de cada célula é utilizada para a produção de soja (dados médios de 1997 para os municípios produtores do Centro-Oeste e Norte); 
- Reserva legal não considerada explicitamente (está incluída implicitamente no item acima);

- Mapa de desmatamento da Amazônia de 1991;

- Considera as áreas protegidas (reservas indígenas, parques nacionais, florestas nacionais, etc.) de âmbito federal e estadual;

- Não são consideradas limitações de relevo nem clima. 
APÊNDICE 3

MAPAS BÁSICOS 


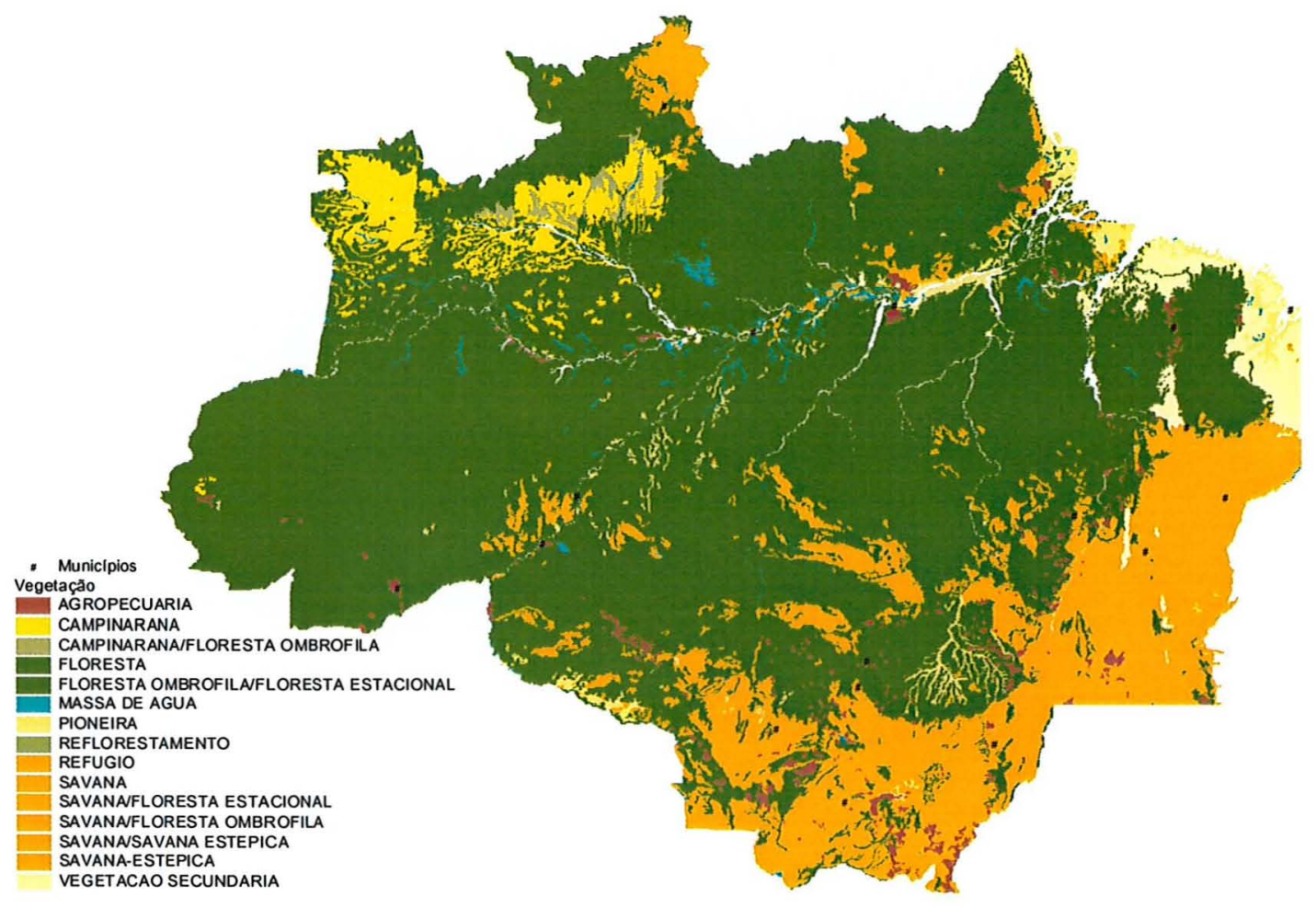

Vegetação da Amazônia 


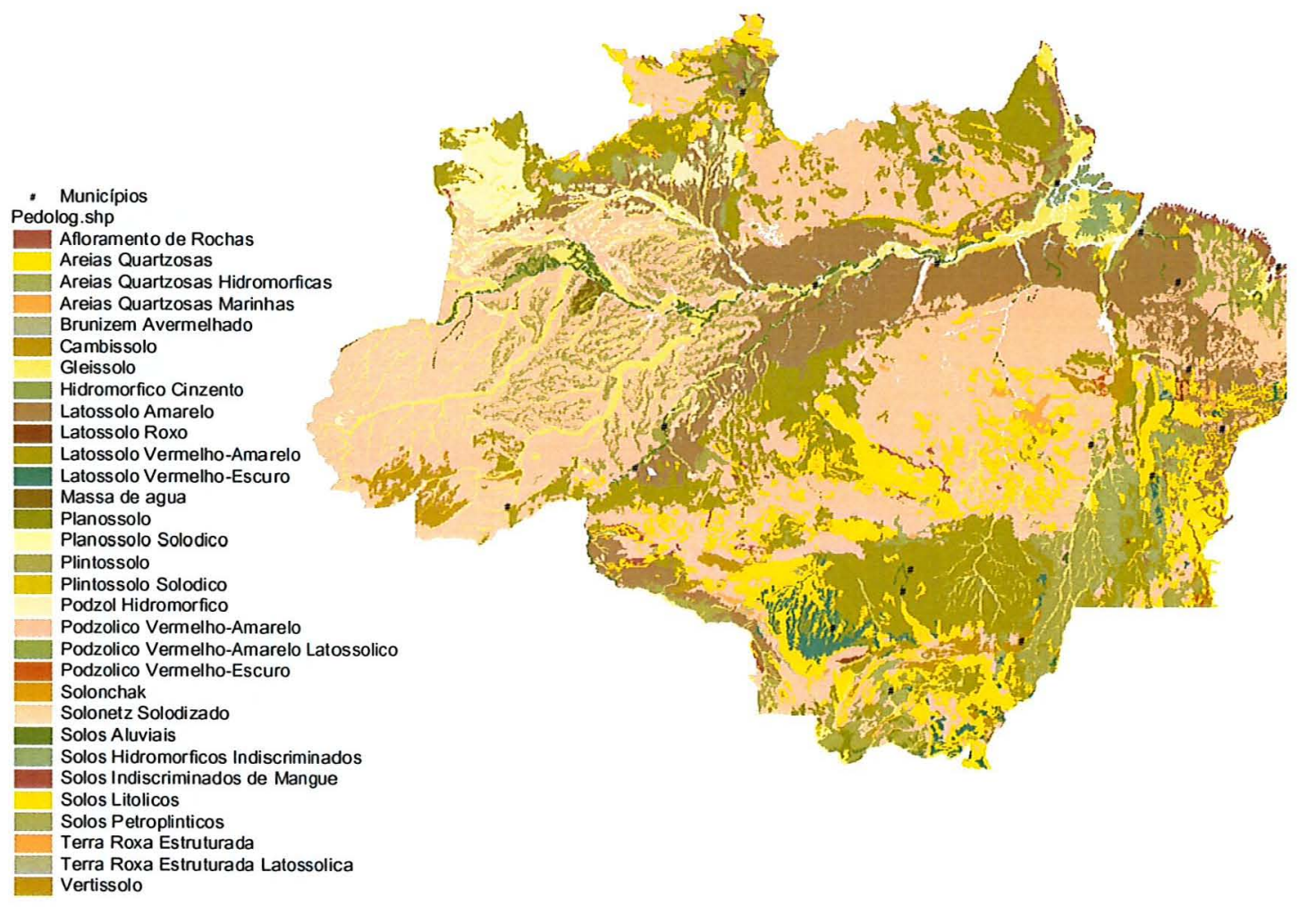

Solos da Amazônia 


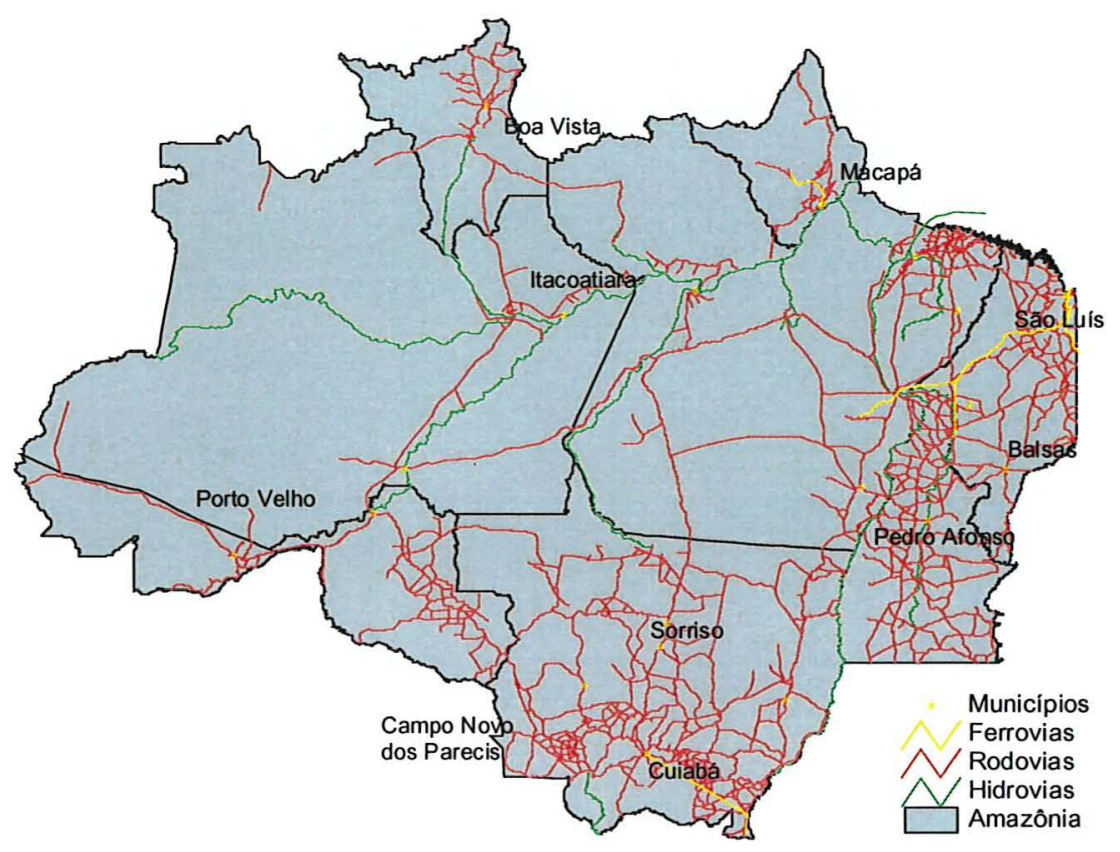

Malha viária e principais municípios da Amazônia Legal 